\title{
RINALDO RODRIGUES
}

Viabilidade econômica de um sistema de produção pecuária de bovinos sob alta lotação: uso na pesquisa e na pecuária comercial 


\section{RINALDO RODRIGUES}

Viabilidade econômica de um sistema de produção pecuária de bovinos sob alta lotação: uso na pesquisa e na pecuária comercial

Dissertação apresentada ao Programa de Pós-graduação em Nutrição e Produção Animal da Faculdade de Medicina Veterinária e Zootecnia da Universidade de São Paulo, para obtenção do título de Mestre em Ciências

Departamento:

Nutrição e Produção Animal

Área de concentração:

Nutrição e Produção Animal

Orientador:

Prof. Dr. Augusto Hauber Gameiro 
Autorizo a reprodução parcial ou total desta obra, para fins acadêmicos, desde que citada a fonte.

\section{DADOS INTERNACIONAIS DE CATALOGAÇÃO-NA-PUBLICAÇÃO}

(Biblioteca Virginie Buff D’Ápice da Faculdade de Medicina Veterinária e Zootecnia da Universidade de São Paulo)

Viabilidade econômica de um sistema de produção pecuária de bovinos sob alta lotação: uso na pesquisa e na pecuária comercial / Rinaldo Rodrigues. $-2010$.

$88 \mathrm{f}$ : : il. + 1 cd-rom com apêndices e anexos

Dissertação (Mestrado) - Universidade de São Paulo. Faculdade de Medicina Veterinária e Zootecnia. Departamento de Nutrição e Produção Animal, São Paulo, 2010.

Programa de Pós-Graduação: Nutrição e Produção Animal. Área de concentração: Nutrição e Produção Animal.

Orientador: Prof. Dr. Augusto Hauber Gameiro.

1. Pecuária bovina. 2. Sistema de produção sustentável. 3. Análise econômica. I. Título. 
ERRATA

RODRIGUES, R. Viabilidade econômica de um sistema de produção pecuária de bovinos sob alta lotação: uso na pesquisa e na pecuária comercial: uso na pesquisa e na pecuária comercial. 2010. 88 f.: il. + 1 cd-rom com apêndices e anexos. Dissertação (Mestrado em Ciências) - Faculdade de Medicina Veterinária, Universidade de São Paulo, Pirassununga, 2010.

Folha Parágrafo

Ficha catalográfica$$
3
$$$$
4
$$

Resumo

1

(

Abstract

29

29
34

54

58

62
Onde se lê

$$
88 \mathrm{f} \text {. }
$$

São Paulo,

Viabilidade econômica de um sistema de produção pecuária de bovinos sob alta lotação: uso na pesquisa e na pecuária comercial: uso na pesquisa e na pecuária comercial.

$$
\begin{aligned}
& 88 \mathrm{f} . \\
& 88 \mathrm{f} . \mathrm{I}
\end{aligned}
$$

Até 0,4 UA/ha/ano

matizes

febre

(15)

\section{Leia-se}

$176 \mathrm{f}$.

Pirassununga,

Viabilidade econômica de um sistema de produção pecuária de bovinos sob alta lotação: uso na pesquisa e na pecuária comercial: uso na pesquisa e na pecuária comercial.

$$
176 \mathrm{f} \text {. }
$$

$176 \mathrm{f}$

Até $1,4 \mathrm{UA} / \mathrm{ha} / \mathrm{ano}$

matrizes

febre aftosa

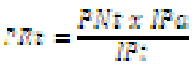

132 UA/15,96ha 


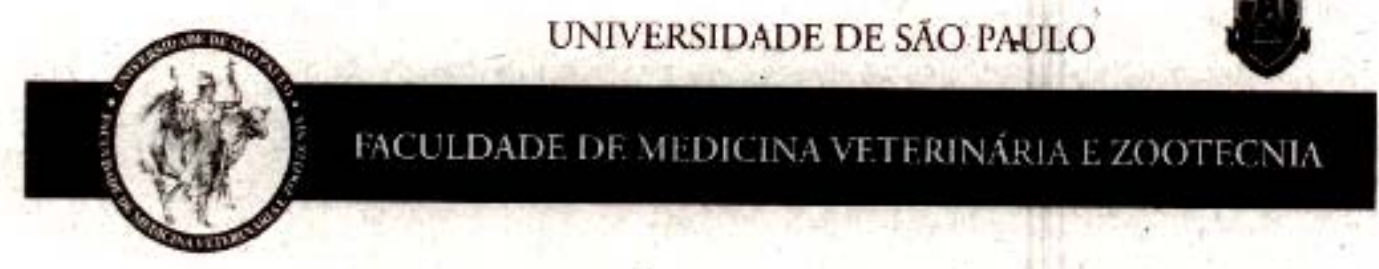

Comissão de Ética no uso de animais

\section{CERTIFICADO}

Certificamos que o Projeto intitulado "Análise da viabilidade econômica de um sistema de produção de pecuária bovina sob alta lotação animal: uso na pesquisa e pecuária comercial", protocolado sob o $n^{\circ} 2052 / 2010$, nāo utilizando animais, sob a responsabilidade do Prof. Dr. Augusto Hauber Gameiro, está de acordo com os princípios éticos de experimentação animal da "Comissão de Ética no uso de animais" da Faculdade de Medicina Veterinária e Zootecnia da Universidade de São Paulo e foi aprovado em reunião de 29/09/2010.

We certify that the Research "Analysis of the economic viability of a production system of cattle under high stocking rate: use in research and commercial livestock", protocol number 2052/2010, under the responsibility Prof. Dr. Augusto Hauber Gameiro, agree with Ethical Principles in Animal Research adopted by "Ethic Committee in the use of animals" of the School of Veterinary Medicine and Animal Science of University of São Paulo and was approved in the meeting of day 09/29/2010.

São Paulo, 30 de setembro de 2010

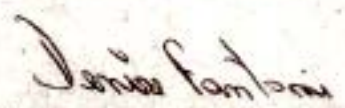

Profa. Dra. Denise Tabacchi Fantoni

Presidente 


\section{FOLHA DE AVALIAÇÃO}

Nome do autor: RODRIGUES, Rinaldo.

Título: Viabilidade econômica de um sistema de produção pecuária de bovinos sob alta lotação: uso na pesquisa e na pecuária comercial

Dissertação apresentada ao Programa de Pós-graduação em Nutrição e Produção Animal da Faculdade de Medicina Veterinária e Zootecnia da Universidade de São Paulo para obtenção do título de Mestre em Ciências

Data:

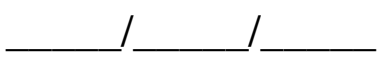

\section{Banca Examinadora}

Prof. Dr. Augusto Hauber Gameiro Assinatura:

Prof. Dr. Luis Felipe Prada e Silva Assinatura:

Prof. Dr. Rubens Nunes

Assinatura:
Instituição: FMVZ

Julgamento:

Instituição: FMVZ

Julgamento:

Instituição: FZEA

Julgamento: 
À minha mãe e ao meu pai:

Dilma Horácio Rodrigues (in memoriam) Adair Rodrigues (in memoriam)

Ao meu eterno amor e aos frutos deste:

Edimara;

Ana Clara e Mariana

Dedico. 
A Deus, Grande Arquiteto Do Universo, pelo dom da vida.

Aos mestres: Prof. Dr. Augusto Hauber Gameiro e Prof. Dr. Luis Felipe Prada e Silva, pela paciência perene. Referências em determinação, profissionalismo, companheirismo, competência, ética e honestidade.

Aos docentes do Departamento de Nutrição e Produção Animal: Prof. Dr. Alexandre Augusto de Oliveira Gobesso, Prof ${ }^{a}$ Dra $^{\mathrm{a}}$ Angélica Simone Cravo Pereira, Prof. Dr. Aníbal de Sant'Anna Moretti, Prof. Dr. Francisco de Palma Rennó, Prof. Dr. Marcos Veiga dos Santos, Prof ${ }^{\mathrm{a}} \mathrm{Dr}^{\mathrm{a}}$ Maria de Fátima Martins, Prof. Dr. Messias Alves da Trindade Neto, Prof. Dr. Paulo Henrique Mazza Rodrigues, Prof. Dr. Ricardo de Albuquerque, Prof. Dr. Romualdo Shigueo Fukushima.

Aos docentes da FZEA: Prof. Dr. Paulo Roberto Leme, Prof. Dr. Pedro Henrique de Cerqueira Luz, Prof. Dr. Rubens Nunes, Prof. Dr. Valdo Rodrigues Herling, pelos ensinamentos.

Às sobrinhas: Profa Dra Ana Carolina Alves e Profa Dra Teresa Cristina Alves, pelos ensinamentos, apoio e orientações.

À equipe da Maccann Engenharia pelo apoio e trabalhos realizados.

Ao Engenheiro Agrônomo Adair Rodrigues Júnior, pelo incentivo, apoio e credibilidade. 


\section{RESUMO}

RODRIGUES, R. Viabilidade econômica de um sistema de produção pecuária de bovinos sob alta lotação: uso na pesquisa e na pecuária comercial: uso na pesquisa e na pecuária comercial. [Economic viability of a cattle system production under high stocking rate: use in research and commercial livestock]. 2010. 88 f.: il. + 1 cd-rom com apêndices e anexos. Dissertação (Mestrado em Ciências) - Faculdade de Medicina Veterinária, Universidade de São Paulo, Pirassununga, 2010.

Um estudo de viabilidade foi desenvolvido com o objetivo de verificar a economicidade de um sistema de produção de ciclo completo de pecuária de bovinos de corte, sob alta lotação. O sistema foi inicialmente concebido para a utilização em pesquisas na Faculdade de Medicina Veterinária e Zootecnia da Universidade de São Paulo, sendo que esta dissertação buscou avaliar a viabilidade econômica de tal sistema quando aplicado à pecuária comercial. Para tanto foram utilizados dez cenários, nove dos quais definidos a partir da variação de preços dos produtos vendidos, utilização de capital próprio e recursos de financiamento rural via programa do Banco Nacional de Desenvolvimento Econômico e Social (BNDES). O décimo cenário utilizado foi definido a partir de um nível pré-determinado de preço dos produtos vendidos e utilização de capital próprio, decorrente de arrendamento de área liberada a partir da intensificação do sistema de produção. O método de análise econômica utilizado foi o de Fluxo de Caixa e as técnicas aplicadas foram: Payback Simples, Payback Descontado, Valor Presente Líquido (VPL) e Taxa Interna de Retorno (TIR). O sistema mostrou-se economicamente viável estritamente para os cenários que consideraram o nível máximo de projeção de preços da arroba da carne e para o cenário que considerou o arrendamento de área liberada a partir da intensificação do sistema de produção. A utilização de financiamento via Programa de Crédito Rural do BNDES proporcionou melhora expressiva nos valores monetários e índices utilizados na análise.

Palavras-chave: Pecuária bovina. Sistema de produção sustentável. Análise econômica. 


\begin{abstract}
RODRIGUES, R. Economic viability of a cattle system production under high stocking rate: use in research and commercial livestock [Viabilidade econômica de um sistema de produção pecuária de bovinos sob alta lotação: uso na pesquisa e na pecuária comercial]. 2010. 88 f.: il. + 1 cd-rom com apêndices e anexos. Dissertação (Mestrado em Ciências) - Faculdade de Medicina Veterinária, Universidade de São Paulo, Pirassununga, 2010.

A study was carried out to verify the economic viability of a life-cycle production system of beef cattle under high stocking. This system was initially designed for use in research at the school of Veterinary Medicine and Animal Science, Universidade São Paulo, but this dissertation tried to evaluate the economic viability of this system when applied to commercial livestock. Therefore, ten scenarios were studied. Nine of them were determined by the variation of prices of products, use of own capital and resources from rural finance programs from Banco Nacional de Desenvolvimento Ecônomico e Social (BNDES). The tenth scenario was based on a predetermined level of prices of products and use of own capital, due to leasing of the area released from the intensification of the production system. The analysis method was the Cash Flow and the applied techniques were: Simple Payback, Discounted Payback, Net Present Value (NPV) and Internal Rate of Return (IRR). The system showed to be economically viable for the scenarios that considered the maximum projection of meat prices and for the scenario that considered the leasing area related to the intensification of the production system. Funding from BNDES Rural Credit Program has provided significant improvement in the monetary values and indices used in the analysis.
\end{abstract}

Keywords: Livestock cattle. Sustainable production system. Economic analysis. 


\section{LISTA DE FIGURAS}

Figura 1 - Componentes de um sistema de produção.......................................26

Figura 2 - Ciclo completo de produção de bovinos no Brasil ...............................27

Figura 3 - Sistemas de produção e especificidades .........................................29

Figura 4 - Tecnologias utilizadas para caracterização de um sistema de produção pecuária.

Figura 5 - Aspectos tecnológicos e quadrantes resultantes da utilização e da eficiência da utilização das tecnologias de produção

Figura 6 - Diagrama detalhado de um processo e obtenção dos indicadores 33

Figura 7 - Representação gráfica de um fluxo de caixa 42

Figura 8 - Representação gráfica de um fluxo de caixa convencional 43

Figura 9 - Representação gráfica de um fluxo de caixa não convencional 44

Figura 10 - Representação gráfica do conceito de capitalização e desconto. 46

Figura 11 - Representação sistemática dos principais métodos de análise econômica aplicados a processos produtivos

Figura $12^{1}$ - Localização da gleba .91

Figura 13 - Aspecto geral da área do empreendimento 92

Figura 14 - Operação de preparo de solo 93

Figura 15 - Execução de levantamento topográfico 93

Figura 16 - Preparo de solo para implantação da cultura da cana de açúcar 96

Figura 17 - Trator de pneus e equipamento agrícola utilizado para o plantio da cana de açúcar 97

Figura 18 - Colocação das mudas nas linhas de plantio de cana de açúcar..... .97

Figura 19 - Cobridor utilizado para o plantio da cana de açúcar .... .98

Figura 20 - Infestação de Cyperus rotundus no talhão de cana de açúcar 98

Figura 21 - Controle químico de invasoras na cultura de cana de açúcar....... .99

Figura 22 - Operação de cultivo simples 100

Figura 23 - Índices pluviométricos totais registrados nos meses de setembro de 2009 a maio do ano de 2010 101

Figura 24 - Aspecto das invasoras após aplicação dos herbicidas 102

\footnotetext{
${ }^{1}$ As figuras 12 até 41 encontram-se nos apêndices.
} 
Figura 25 - Operação de gradagem após aplicação dos herbicidas

Figura 26 - Aspecto da gleba após operações de preparo de solo para plantio das pastagens

Figura 27 - Operação mecanizada de semeadura das pastagens 104

Figura 28 - Preparo da semente de Panicum maximum cv Mombaça... 105

Figura 29 - Aferição do peso das sementes de Panicum maximum cv Mombaça, lançadas por unidade de área 105

Figura 30 - Contagem da quantidade de sementes de Panicum maximum cv Mombaça, lançadas por unidade de área.

Figura 31 - Contagem da quantidade de sementes de Brachiaria brizantha cv Marandu, lançadas por unidade de área 106

Figura 32 - Utilização de grade intermediária - destravada - para cobertura das sementes das pastagens

Figura 33 - Alta infestação de invasoras nas áreas de pastagens - piquete 1 em 20 de março de 2010 108

Figura 34 - Alta infestação de invasoras nas áreas de pastagens - piquete 1 em 15 de abril de 2010

Figura 35 - Efeito fitotóxico apresentado pelas invasoras 07 dias após aplicação dos herbicidas - piquete 1 109

Figura 36 - Aspecto da forrageira instalada 20 dias após aplicação dos herbicidas piquete 1

Figura 37 - Limpeza do terreno

Figura 38 - Corte e regularização das cotas de projeto 112

Figura 39 - Movimentação de terra na área de implantação do confinamento.

Figura 40 - Medição para o ajuste de cotas de corte

Figura 41 - Execução do ajuste de cotas de corte 


\section{LISTA DE GRÁFICOS}

Gráfico 1 - Médias anuais dos preços corrigidos - 2000-2010 .58 


\section{LISTA DE QUADROS}

Quadro 1 - Caracterização das atividades econômicas da pecuária de corte desenvolvidas de forma isolada ou complementar ...............................28

Quadro 2 - Comparação de denominações em projetos...........................................36

Quadro $3^{2}$ - Identificação, descrição e áreas da gleba.............................................94

Quadro 4 - Recomendação para aplicação de herbicidas nas pastagens ...............108

${ }^{2}$ Quadros 3 e 4 encontram-se nos apêndices. 


\section{LISTA DE TABELAS}

Tabela 1 - Estoque de bovinos em países selecionados, variação percentual no período e total mundial - 2000/2002/2004/2006/2008

Tabela 2 - Taxa de desfrute do rebanho em países selecionados no total mundial 2000/2002/2004/2006/2008.

Tabela 3 - Peso médio das carcaças do rebanho em países selecionados no total mundial - 2000/2002/2004/2006/2008

Tabela 4 - Distribuição do efetivo bovino por regiões geográficas - 2000-2008

Tabela 5 - Áreas dos estabelecimentos agropecuários por utilização das terras 1970/1975/1980/1985/2006

Tabela 6 - Taxa de desfrute do rebanho bovino no Brasil por regiões geográficas 2000-2008

Tabela 7 - Valores e participações do PIB do agronegócio do Brasil - 2008

Tabela 8 - Fluxo de caixa para cálculo do Payback Descontado de um projeto de seis anos

Tabela 9 - Projeção de comercialização de animais por sexo e categoria animal 2010-2017

Tabela 10 - Saldo devedor, prestação, juros e amortizações decorrentes de operação de crédito rural com pagamento dos juros incorporados ao valor inicial da dívida após o período de carência 60

Tabela 11 - Saldo devedor, prestação, juros e amortizações decorrentes de operação de crédito rural com pagamento dos juros devidos no período de carência

Tabela 12 - Cenários para a determinação da viabilidade econômica do empreendimento obtidos a partir das definições das fontes de recursos monetários, modalidade de pagamento das prestações decorrentes de financiamento de terceiros e preços de venda dos produtos auferidos com base nas médias corrigidas dos preços, da arroba de carne.

Tabela 13 - Projeção do fluxo de caixa do empreendimento com utilização de recursos próprios e receita bruta auferida a partir da venda de animais com a utilização da média mínima dos preços corrigidos - 2009-2038..63 
Tabela 14 - Projeção dos fluxos de caixa do empreendimento com a utilização de recursos de terceiros decorrentes de operação de crédito rural com pagamento dos juros incorporados ao valor inicial da dívida após o período de carência e receita bruta auferida a partir da venda de animais com a utilização da média mínima dos preços corrigidos - 2009-2038..64

Tabela 15 - Projeção dos fluxos de caixa do empreendimento com a utilização de recursos de terceiros decorrentes de operação de crédito rural com pagamento dos juros devidos no período de carência e receita bruta auferida a partir da venda de animais com a utilização da média mínima dos preços corrigidos - 2009-2038.

Tabela 16 - Projeção dos fluxos de caixa do empreendimento com a utilização de recursos próprios e receita bruta auferida a partir da venda de animais com a utilização da média geral dos preços corrigidos - 2009-2038 ....66

Tabela 17 - Projeção dos fluxos de caixa do empreendimento com a utilização de recursos de terceiros decorrentes de operação de crédito rural com pagamento dos juros incorporados ao valor inicial da dívida após o período de carência e receita bruta auferida a partir da venda de animais com a utilização da média geral dos preços corrigidos - 2009-2038 ....68

Tabela 18 - Projeção dos fluxos de caixa do empreendimento com a utilização de recursos de terceiros decorrentes de operação de crédito rural com pagamento dos juros devidos no período de carência e receita bruta auferida a partir da venda de animais com a utilização da média geral dos preços corrigidos - 2009-2038.

Tabela 19 - Projeção dos fluxos de caixa do empreendimento com a utilização de recursos próprios e receita bruta auferida a partir da venda de animais com a utilização da média máxima dos preços corrigidos - 2009-2038.70

Tabela 20 - Projeção dos fluxos de caixa do empreendimento com a utilização de recursos de terceiros decorrentes de operação de crédito rural com pagamento dos juros incorporados ao valor inicial da dívida após o período de carência e receita bruta auferida a partir da venda de animais com a utilização da média máxima dos preços corrigidos - 2009-2038.71

Tabela 21 - Projeção dos fluxos de caixa do empreendimento com a utilização de recursos de terceiros decorrentes de operação de crédito rural com pagamento dos juros devidos no período de carência e receita bruta 
auferida a partir da venda de animais com a utilização da média máxima dos preços corrigidos - 2009-2038.

Tabela 22 - Projeção dos fluxos de caixa do empreendimento com a utilização de recursos próprios, receita bruta auferida a partir da venda de animais e entrada de caixa decorrente do arrendamento da terra, com utilização de média geral dos preços corrigidos - 2009-2038 73

Tabela 23 - Determinação da viabilidade econômica do empreendimento, a partir das diferentes técnicas de análise para os diferentes cenários propostos.

Tabela $24^{3}$ - Resultado das análises dos solos da gleba .95

Tabela 25 - Evolução do rebanho em número de animais - 2010 116

Tabela 26 - Evolução do rebanho em número de animais - 2011 117

Tabela 27 - Evolução do rebanho em número de animais - 2012 118

Tabela 28 - Evolução do rebanho em número de animais - 2013 119

Tabela 29 - Evolução do rebanho em número de animais - 2014 120

Tabela 30 - Evolução do rebanho em número de animais - 2015 120

Tabela 31 - Evolução do rebanho em número de animais - 2016 121

Tabela 32 - Total de unidades animais distribuídas mensalmente no sistema de pastejo - 2010-2017

\footnotetext{
${ }^{3}$ As tabelas 24 até a tabela 32 encontram-se nos apêndices.
} 


\section{LISTA DE APÊNDICES}

APÊNDICE A - Definição dos objetivos do empreendimento ............................. 89

APÊNDICE B - Infraestrutura do empreendimento ...................................... 91

APÊNDICE C - Caracterização do sistema de produção ...................................116

APÊNDICE D - Memorial de cálculo para deflacionamento das médias nominais mensais dos preços da arroba de carne bovina e atualização para valores reais equivalentes para o mês de julho de 2010 ..............125

APÊNDICE E - Infraestrutura e instalações ..............................................128

APÊNDICE F - Formação, manutenção e reforma da lavoura de cana de açúcar..130

APÊNDICE G - Formação e manutenção das pastagens ...................................144

APÊNDICE H - Manejo do rebanho ................................................. 158 


\section{LISTA DE ANEXOS}

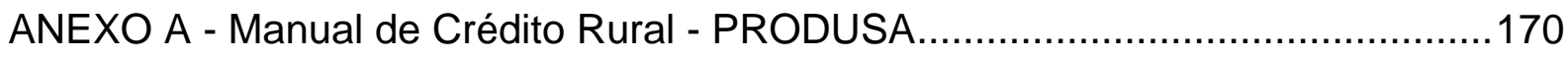

ANEXO B - Projeto de Layout e Implantação.....................................................175

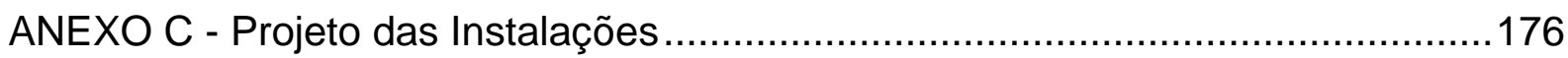




\section{SUMÁRIO}

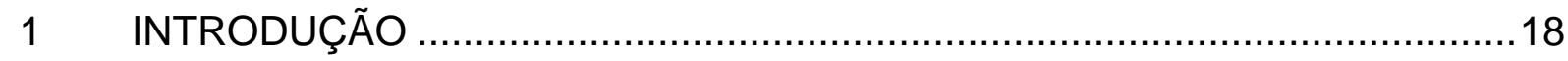

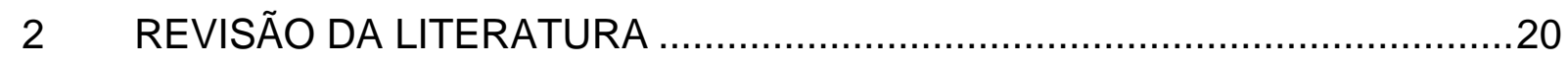

2.1 Contexto e desafios para a pecuária de corte brasileira.................................20

2.2 Sistemas de produção da pecuária de corte ..............................................25

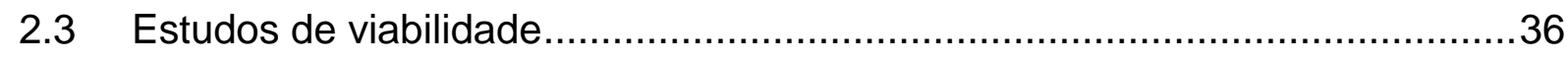

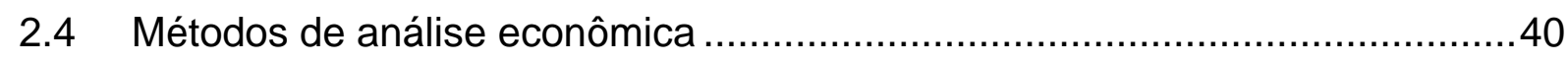

2.5 Métodos de análise econômica baseados em fluxos de caixa ........................42

2.6 Análises econômicas aplicadas na pecuária de corte ....................................52



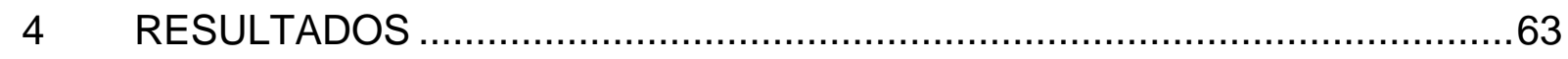

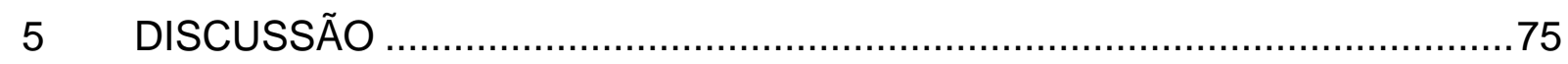

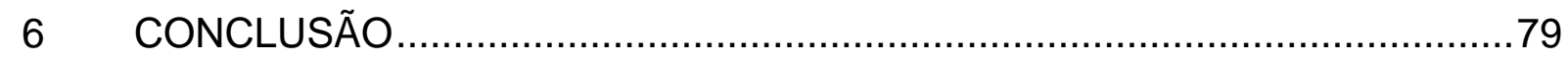

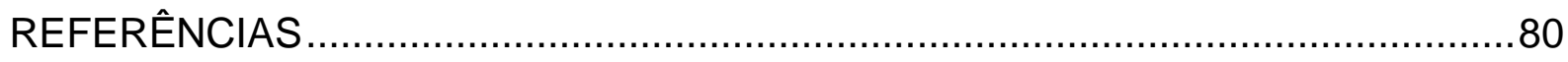



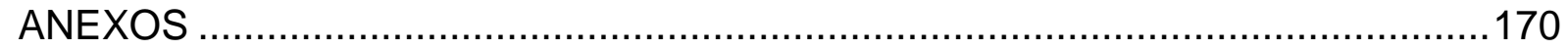




\section{INTRODUÇÃO}

O Brasil ocupa lugar de destaque quando comparado aos principais países produtores de bovinos de corte, em relação: ao tamanho do rebanho, à produção e à comercialização de seus produtos. Expressiva também é a participação da pecuária no agronegócio do Brasil.

Apesar da supremacia em termos numéricos sabe-se que bovinocultura de corte brasileira caracteriza-se pela utilização de modelos de produção ditos extensivos. De eficiência questionável, esses modelos baseiam-se na exploração das atividades em grandes áreas geográficas com pouca utilização de insumos e de tecnologias avançadas de produção. Da utilização de novas tecnologias, melhorias do potencial de resposta dos animais e da necessidade da exploração racional dos recursos de produção surgiram sistemas mais especializados, denominados intensivos. Esses, quando considerados sistematicamente, podem constituir alternativa na busca para o desenvolvimento sustentável da atividade pecuária, quando da sua exploração comercial.

A importância do setor na economia e as demandas relacionadas à sustentabilidade dos sistemas produtivos apontam para que entidades organizacionais públicas e privadas ocupem parte de seus esforços e investimentos na pesquisa e aplicação de alternativas tecnológicas que tornem a produção mais eficiente. Inúmeras pesquisas são conduzidas com vistas ao aumento da produtividade dos rebanhos, porém nota-se que nem sempre as tecnologias de produção são estudadas interativamente. Assim, o conjunto isolado de dados e informações podem ser insuficientes para responder questionamentos relacionados à viabilidade de empreendimentos com diferentes graus de utilizações das tecnologias de produção.

Visando a realização de pesquisas zootécnicas na área de bovinocultura de corte pelo Departamento de Nutrição e Produção Animal (VNP), da FMVZ/USP, foi idealizado ${ }^{4}$ um sistema de produção no qual as tecnologias pudessem ser estudadas interativamente.

\footnotetext{
${ }^{4}$ Originalmente idealizado pelo Prof. Dr. Luis Felipe Prada e Silva.
} 
O planejamento de projeto e a execução do empreendimento suscitou o questionamento de que se tal sistema de produção - com a utilização da mesma infraestrutura e tecnologias de produção - poderia ser viável economicamente para a aplicação na bovinocultura de corte com fins comercias. Esta demanda originou a pesquisa realizada nesta dissertação, onde a questão central a ser respondida foi:

Um sistema de produção pecuária de bovinos de corte - sob alta lotação animal e com ciclo completo de produção - proposto para a implantação de pesquisas zootécnicas pode ser viável economicamente sob a ótica comercial da bovinocultura de corte?

O objetivo deste trabalho foi verificar a viabilidade econômica de tal sistema de produção, configurado para a pesquisa zootécnica e justificar o incremento da utilização das tecnologias de produção (intensificação do sistema). Para tanto, desenvolveu-se simulações para avaliar a sensibilidade do sistema, em relação: aos preços da arroba de carne praticados no mercado, às possíveis decisões de investimentos com a utilização de capital próprio e ou via utilização de financiamento ${ }^{5}$ e a uma situação na qual se considerou a economia do fator de produção terra ao permitir a atividade pecuária numa área reduzida em relação aos sistemas extensivos.

Justifica-se desta forma a elaboração deste trabalho no sentido de aproximar resultados da pesquisa às práticas produtivas do setor comercial.

\footnotetext{
${ }^{5}$ As simulações com a utilização de financiamento foram realizadas a partir de linha de crédito do Programa de Crédito Rural do Banco Nacional de Desenvolvimento Econômico e Social (BNDES).
} 


\section{REVISÃO DA LITERATURA}

\subsection{Contexto e desafios para a pecuária de corte brasileira}

A pecuária de bovinos brasileira se destaca no cenário mundial, quando comparada aos países detentores dos maiores rebanhos ${ }^{6}$ (Tabela 1 ).

Tabela 1 - Estoque de bovinos em países selecionados, variação percentual no período e total mundial - 2000/2002/2004/2006/2008

\begin{tabular}{lrrrrrr}
\hline \multirow{2}{*}{ Países e total mundial } & \multicolumn{4}{c}{ Número de animais (cabeças) } & \multicolumn{1}{c}{$\Delta \%$} \\
\cline { 2 - 6 } & \multicolumn{1}{c}{2000} & \multicolumn{1}{c}{2002} & \multicolumn{1}{c}{2004} & \multicolumn{1}{c}{2006} & 2008 & $2008 / 2000$ \\
\hline Argentina & 48.674 .400 & 50.869 .000 & 50.167 .000 & 50.700 .000 & 50.750 .000 & 4,26 \\
Brasil & 169.875 .520 & 195.551 .576 & 207.156 .696 & 205.886 .244 & 175.436 .992 & 3,27 \\
China & 104.553 .559 & 93.099 .589 & 90.134 .331 & 87.548 .391 & 82.623 .951 & $-20,97$ \\
Estados Unidos & 98.198 .000 & 96.100 .000 & 95.438 .000 & 96.701 .500 & 96.669 .000 & $-1,56$ \\
União Europeia & 97.635 .696 & 92.784 .371 & 91.305 .830 & 90.517 .355 & 90.500 .009 & $-7,31$ \\
\hline Total mundial & 1.315 .876 .464 & 1.325 .877 .451 & 1.344 .220 .749 & 1.362 .050 .100 & 1.347 .473 .112 & 2,40 \\
\hline
\end{tabular}

Fonte de dados brutos: FAO, 2010.

Em relação ao total de animais vivos - disponíveis para comercialização - o Brasil é considerado líder mundial, tendo assumido essa posição desde o início da década de 90, quando os Estados Unidos passaram para a segunda posição no ranking (FAO, 2010).

As exportações brasileiras de carne bovina também ocupam posição de destaque no mercado mundial. Em primeiro lugar no ranking dos países exportadores desde 2004, o Brasil foi o que apresentou maior crescimento relativo nas últimas décadas. As exportações passaram de 541 mil toneladas, em 1999, para 2.194 mil toneladas em 2008 (ANUALPEC, 2008).

Embora importantes e largamente utilizadas para descrever e posicionar a pecuária brasileira, estas informações são insuficientes para a avaliação da eficiência do setor, tampouco dos sistemas de produção. Em termos quantitativos a taxa de desfrute ${ }^{7}$ do rebanho do Brasil, embora com variação positiva no período,

\footnotetext{
${ }^{6}$ Optou-se por não considerar o rebanho bovino da Índia, pois não se trata de rebanho destinado à atividade comercial.

${ }^{7}$ Relação entre o total abatido e o total do rebanho.
} 
apresentou os menores índices anuais quando comparada às dos países selecionados e à média mundial (Tabela 2).

Tabela 2 - Taxa de desfrute do rebanho em países selecionados no total mundial 2000/2002/2004/2006/2008

\begin{tabular}{lcccccc}
\hline \multirow{2}{*}{ Países e total mundial } & \multicolumn{3}{c}{ Taxa de desfrute (\%) } & \multicolumn{1}{c}{$\Delta \%$} \\
\cline { 2 - 6 } & 2000 & 2002 & 2004 & 2006 & 2008 & 4,42 \\
\hline Argentina & 25,48 & 22,61 & 28,50 & 26,44 & 26,60 & 2000 \\
Brasil & 18,33 & 17,64 & 17,62 & 20,02 & 22,68 & 23,73 \\
China & 34,56 & 39,46 & 44,42 & 47,49 & 52,74 & 52,59 \\
Estados Unidos & 38,28 & 38,47 & 35,37 & 35,00 & 35,70 & $-6,72$ \\
União Europeia & 33,48 & 34,28 & 33,19 & 32,41 & 31,90 & $-4,71$ \\
\hline Total mundial & 22,08 & 21,94 & 22,25 & 22,48 & 22,94 & 3,93 \\
\hline
\end{tabular}

Fonte de dados brutos: FAO, 2010.

Porém, se observado o peso médio das carcaças dos rebanhos nos países selecionados, nota-se que as taxas superiores alcançadas pela China podem ser atribuídas ao abate de animais mais jovens - consequentemente mais leves - e ou animais mais leves, fato também observado em relação à Argentina e que se comprova por meio dos dados apresentados na tabela 3.

Tabela 3 - Peso médio das carcaças do rebanho em países selecionados no total mundial 2000/2002/2004/2006/2008

\begin{tabular}{lcccccc}
\hline \multirow{2}{*}{ Países e total mundial } & \multicolumn{4}{c}{ Peso médio da carcaça $(\mathrm{kg})$} & \multicolumn{1}{c}{$\Delta \%$} \\
\cline { 2 - 6 } & 2000 & 2002 & 2004 & 2006 & 2008 & $2008 / 2000$ \\
\hline Argentina & 219 & 217 & 212 & 209 & 210 & $-4,36$ \\
Brasil & 211 & 207 & 213 & 219 & 227 & 7,35 \\
China & 133 & 132 & 132 & 132 & 134 & 1,09 \\
Estados Unidos & 327 & 336 & 331 & 352 & 355 & 8,35 \\
União Europeia & 257 & 260 & 272 & 276 & 277 & 7,91 \\
\hline Total mundial & 195 & 197 & 196 & 199 & 202 & 3,30 \\
\hline
\end{tabular}

Fonte de dados brutos: FAO, 2010.

Nota-se desta forma que, apesar da liderança aparente em termos quantitativos, a pecuária de corte brasileira passa por um período de aumento das medidas de desempenho da produção, podendo este ser melhorado sobremaneira, quando comparados aos das outras nações que apresentam destaque na produção de bovinos.

O desempenho do setor pode ser analisado no contexto do País, porém alguns aspectos devem ser observados por unidade da Federação, visto a diversidade dos sistemas de produção utilizados. No Brasil a distribuição do rebanho 
de bovinos é definida em termos geográficos com base em cinco regiões, sendo a região Centro-Oeste a detentora do maior numero de animais (34,07\%), seguida das regiões: Norte $(19,34 \%)$, Sudeste $(18,70 \%)$, Nordeste $(14,26 \%)$ e Sul $(13,63 \%)$, em termos percentuais de distribuição (IBGE, 2010a).

Em relação à evolução do rebanho, notaram-se altas taxas de crescimento nas regiões Norte, Nordeste e Centro-Oeste (Tabela 4).

Tabela 4 - Distribuição do efetivo bovino por regiões geográficas - 2000-2008

\begin{tabular}{|c|c|c|c|c|c|c|c|c|c|c|}
\hline \multirow{2}{*}{$\begin{array}{l}\text { Brasil e } \\
\text { regiões }\end{array}$} & \multicolumn{9}{|c|}{ Efetivo (1.000 cabeças) } & \multirow{2}{*}{$\begin{array}{c}\Delta \% \\
2008 / 20 \\
00\end{array}$} \\
\hline & 2000 & 2001 & 2002 & 2003 & 2004 & 2005 & 2006 & 2007 & 2008 & \\
\hline Brasil & 169.876 & 176.388 & 185.349 & 195.552 & 204.512 & 207.157 & 205.886 & 199.753 & 202.287 & 19,08 \\
\hline Norte & 24.518 & 27.284 & 30.429 & 33.930 & 39.787 & 41.489 & 41.060 & 37.867 & 39.119 & 59,56 \\
\hline Nordeste & 22.567 & 23.414 & 23.892 & 24.992 & 25.966 & 26.969 & 27.881 & 28.711 & 28.852 & 27,85 \\
\hline Sudeste & 36.852 & 37.119 & 37.924 & 38.711 & 39.379 & 38.944 & 39.209 & 38.587 & 37.820 & 2,63 \\
\hline Sul & 26.298 & 26.784 & 27.537 & 28.030 & 28.211 & 27.770 & 27.200 & 26.500 & 27.566 & 4,82 \\
\hline $\begin{array}{l}\text { Centro- } \\
\text { Oeste }\end{array}$ & 59.641 & 61.787 & 65.567 & 69.889 & 71.169 & 71.985 & 70.536 & 68.088 & 68.930 & 15,57 \\
\hline
\end{tabular}

Fonte de dados brutos: IBGE, 2010a.

Segundo Füsternau (2004), o deslocamento da produção vem sendo observado desde a década de 70 , quando estados da região Sudeste perderam posição em função da expansão das fronteiras agrícolas. Nas regiões onde houve aumento do número de animais, observou-se também o aumento nas áreas de pastagem (Tabela 5).

Tabela 5 - Áreas dos estabelecimentos agropecuários por utilização das terras 1970/1975/1980/1985/2006

\begin{tabular}{|c|c|c|c|c|c|c|c|c|}
\hline \multirow{2}{*}{$\begin{array}{l}\text { Brasil e } \\
\text { regiões }\end{array}$} & & \multicolumn{6}{|c|}{ Utilização das terras (1.000 hectares) } & \multirow{2}{*}{$\begin{array}{c}\Delta \% \\
2006- \\
1970 \\
\end{array}$} \\
\hline & & 1970 & 1975 & 1980 & 1985 & 1995 & 2006 & \\
\hline \multirow[t]{2}{*}{ Brasil } & Lavoura & 33.983 & 40 & 49 & 52 & 41 & 59.846 & 76,10 \\
\hline & Pastagem & 154 & 165 & 174 & 179 & 177 & 158.753 & 2,99 \\
\hline \multirow[t]{2}{*}{ Norte } & Lavoura & 617 & 1.195 & 1.743 & 2.680 & 1.972 & 4.205 & 581,53 \\
\hline & Pastagem & 4.428 & 5.281 & 7.722 & 20.876 & 24.386 & 26.524 & 498,99 \\
\hline \multirow[t]{2}{*}{ Nordeste } & Lavoura & 10.322 & 11.033 & 14.191 & 14.335 & 10.345 & 15.162 & 46,89 \\
\hline & Pastagem & 27.875 & 30.624 & 34.158 & 35.148 & 32.076 & 30.539 & 9,56 \\
\hline \multirow[t]{2}{*}{ Sudeste } & Lavoura & 9.612 & 10.431 & 12.117 & 13.561 & 10.594 & 13.172 & 37,04 \\
\hline & Pastagem & 44.739 & 47.276 & 43.639 & 42.487 & 37.777 & 27.561 & $-38,40$ \\
\hline \multirow[t]{2}{*}{ Sul } & Lavoura & 11.028 & 12.991 & 14.571 & 14.523 & 12.306 & 15.094 & 36,87 \\
\hline & Pastagem & 21.612 & 21.159 & 21.313 & 21.432 & 20.696 & 15.610 & $-27,77$ \\
\hline \multirow[t]{2}{*}{ Centro-Oeste } & Lavoura & 2.402 & 4.349 & 6.480 & 7.046 & 6.576 .653 & 12.211 .556 & 408,20 \\
\hline & Pastagem & 55.483 & 61.310 & 67.665 & 59.244 & 62.763 .912 & 58.518 .216 & 5,47 \\
\hline
\end{tabular}

Fonte de dados brutos: IBGE, 2010a. 
Assim, pode-se concluir que a atividade dita extensiva migrou para regiões de terras mais baratas, com o objetivo de garantir o mínimo de retorno ao investimento. Em outras regiões - Sudeste e Sul - as áreas de pastagens cederam lugar às lavouras, devido à elevação do preço das terras e exigência econômica de se atingir escalas de produção cada vez maiores (BIERHALS; FERRAZ, 2008).

Apesar do incremento nos índices de produtividade e do aumento das exportações observado nos últimos anos, esses continuam aquém do potencial do país. A causa - dentre outras - está na utilização de sistemas de produção pouco eficientes, que resultam na baixa produtividade conjunta dos sistemas de produção (Tabela 6).

Tabela 6 - Taxa de desfrute do rebanho bovino no Brasil por regiões geográficas - 2000-2008

\begin{tabular}{|c|c|c|c|c|c|c|c|c|c|c|}
\hline \multirow{2}{*}{$\begin{array}{l}\text { Brasil e } \\
\text { regiões }\end{array}$} & \multicolumn{9}{|c|}{ Taxa de desfrute (\%) } & \multirow{2}{*}{$\begin{array}{c}\Delta \% \\
2008 / 2000\end{array}$} \\
\hline & 2000 & 2001 & 2002 & 2003 & 2004 & 2005 & 2006 & 2007 & 2008 & \\
\hline Brasil & 9,32 & 9,72 & 10,14 & 11,99 & 11,98 & 12,92 & 14,17 & 14,74 & $13,80^{1}$ & 41,97 \\
\hline Norte & 8,31 & 8,17 & 9,34 & 9,08 & 9,04 & 10,38 & 13,29 & 16,59 & 13,66 & 64,39 \\
\hline Nordeste & 7,08 & 7,42 & 8,02 & 8,17 & 8,34 & 8,84 & 10,02 & 10,88 & 11,17 & 57,70 \\
\hline Sudeste & 10,09 & 13,05 & 13,55 & 21,84 & 17,05 & 17,30 & 17,41 & 18,49 & 18,61 & 84,43 \\
\hline Sul & 8,89 & 8,07 & 8,02 & 8,75 & 11,35 & 13,26 & 14,00 & 11,33 & 10,95 & 23,16 \\
\hline Centro-Oeste & 12,21 & 11,90 & 11,76 & 12,11 & 14,13 & 14,84 & 16,15 & 16,41 & 14,62 & 19,69 \\
\hline
\end{tabular}

Fonte de dados brutos: IBGE, 2010a.

${ }^{1}$ Nota-se que o índice difere ao apresentado na tabela 3 , devido às fontes pesquisadas serem diferentes.

Embora com características e desempenho específicos e passíveis de melhoria, é inegável a importância e a participação da atividade pecuária na composição do $\mathrm{PIB}^{8}$ do agronegócio do Brasil e, consequentemente na economia brasileira, conforme se observa na tabela 7 .

\footnotetext{
${ }^{8} \mathrm{O}$ Produto Interno Bruto (PIB) é um dos indicadores mais utilizados na macroeconomia com o objetivo de mensurar a atividade econômica de uma região. Representa a soma - em valores monetários - de todos os bens e serviços finais produzidos numa determinada região - quer seja, países, estados, cidades - durante um período determinado - mês, trimestre, ano, etc.
} 
Tabela 7 - Valores e participações do PIB do agronegócio do Brasil - 2008

\begin{tabular}{|c|c|c|c|}
\hline \multirow[b]{2}{*}{ Agronegócio } & \multicolumn{3}{|c|}{2008} \\
\hline & VALORES $^{1}$ (milhões) & $\begin{array}{l}\text { PARTICIPAÇÃO } \\
\text { GERAL }^{2}(\%)\end{array}$ & $\begin{array}{l}\text { PARTICIPAÇÃO POR } \\
\text { SETOR }^{3}(\%)\end{array}$ \\
\hline Agropecuária & 201.009 & 6,96 & 26,29 \\
\hline Insumos (geral) & 90.025 & 3,12 & 11,78 \\
\hline Indústria & 231.261 & 8,00 & 30,25 \\
\hline Distribuição & 242.199 & 8,38 & 31,68 \\
\hline Total $^{4}$ & 764.494 & 26,46 & 100 \\
\hline Agricultura & 115.935 & 4,01 & 21,50 \\
\hline Insumos (geral) & 57.127 & 1,98 & 10,60 \\
\hline Indústria & 197.985 & 6,85 & 36,73 \\
\hline Distribuição & 168.042 & 5,82 & 31,17 \\
\hline Total $^{5}$ & 539.089 & 18,66 & 100 \\
\hline Pecuária $^{6}$ & 85.073 & 2,94 & 37,74 \\
\hline Insumos (geral) & 32.898 & 1,14 & 14,60 \\
\hline Indústria & 33.276 & 1,15 & 14,76 \\
\hline Distribuição & 74.157 & 2,57 & 32,90 \\
\hline Total $^{7}$ & 225.405 & 7,80 & 100 \\
\hline
\end{tabular}

Fonte de dados brutos: Adaptado do CEPEA, 2010.

Nota: Três trilhões foi aproximadamente o PIB do Brasil no ano de 2008 (IBGE).

${ }^{1}$ Valores do PIB do agronegócio brasileiro. ${ }^{2}$ Participação no PIB do agronegócio. ${ }^{3}$ Participação de cada segmento no PIB do agronegócio. ${ }^{4}$ Somatória dos itens Agricultura e Pecuária. ${ }^{5}$ Somatória dos itens Agricultura. ${ }^{6}$ Incluem bovinos, suínos, aves vivas e outros produtos agropecuários (produtos animais). ${ }^{7}$ Somatória dos itens Pecuária.

Segundo Torres e Tonini (2009), o consumo de carne bovina tem correlação direta com o número de habitantes, renda da população e com fatores indiretos, como hábitos culturais, distribuição de renda e religião, entre outros. Porém o crescimento da população aliado ao crescimento da renda são os principais elementos direcionadores na demanda de carne bovina.

Ainda, os autores - baseados em dados da FAO/OEDC/FAPRI ${ }^{9}$ (2008) projetam o crescimento mundial da população no período de 2007 para 2017 em 1,12\% ao ano, elevando o número de pessoas de 6,6 bilhões para 7,4 bilhões. Com relação ao PIB, estimam o crescimento baseados em previsão do FAPRI, para o mesmo período, em torno de 3,3\% ao ano. Estimam - baseados nos fatores de crescimento populacional e renda - que o consumo de carne bovina mundial deverá crescer em $23 \%$ no final do período projetado, alcançando 83,7 milhões de toneladas equivalente-carcaça no ano de 2020. Tendo o Brasil o maior rebanho bovino comercial do mundo e acompanhando-se as variações apresentadas nas

\footnotetext{
${ }^{9}$ Food and Agriculture Organization / Organization for Economic Co-operation and Development / Food and Agriculture Policy Research Institute.
} 
tabelas 1 e 2, mantendo-se os percentuais de crescimento e participações dos países produtores de carne, poder-se-ia no mínimo supor que o rebanho deverá crescer aos mesmos 23\%. Assim no final do período em questão estima-se que o Brasil deverá apresentar um efetivo de 216 milhões de cabeças, de acordo com os dados da FAO (2010) e 249 milhões de cabeças, segundo o IBGE (2010a). Desta forma no final de 2017 - projetando-se o crescimento do rebanho em 1,27\% ao ano, com base na variação entre 2007 e 2008 segundo o IBGE (2010a) - dificilmente esta meta de crescimento será atingida.

Em termos numéricos - mantidas as condições de eficiência, somando-se a questões socioambientais, competição com a agricultura, preços e relacionamento com o mercado internacional - tem-se um desafio considerável para a pecuária bovina brasileira. Assim põe-se em questão a eficiência atual dos sistemas de produção no que se refere aos aspectos tecnológicos e econômicos.

\subsection{Sistemas de produção da pecuária de corte}

As organizações ocupam-se em produzir bens e serviços por meio das suas atividades funcionais, ou funções. A produção é a função que se ocupa em transformar insumos, informações, tecnologias, dentre outros, em produtos e serviços demandados pelo mercado (SLACK, 1999).

A eficiência econômica dos sistemas de produção é determinada por meio da combinação e aplicação das tecnologias de produção existentes. A essa combinação denomina-se processo produtivo.

Na pecuária de corte entende-se por sistema de produção o conjunto de tecnologias e práticas de manejo, bem como o tipo de animal, o propósito da criação, a raça ou grupamento genético e a ecorregião onde a atividade é desenvolvida (EUCLIDES FILHO, 2000).

A avaliação da viabilidade econômica de um sistema de produção requer a correta definição e dimensionamento dos seus componentes, definidos na figura 1. Estes são a base para a compreensão do processo produtivo e das variáveis que influenciam no desempenho econômico da atividade da pecuária de corte. 


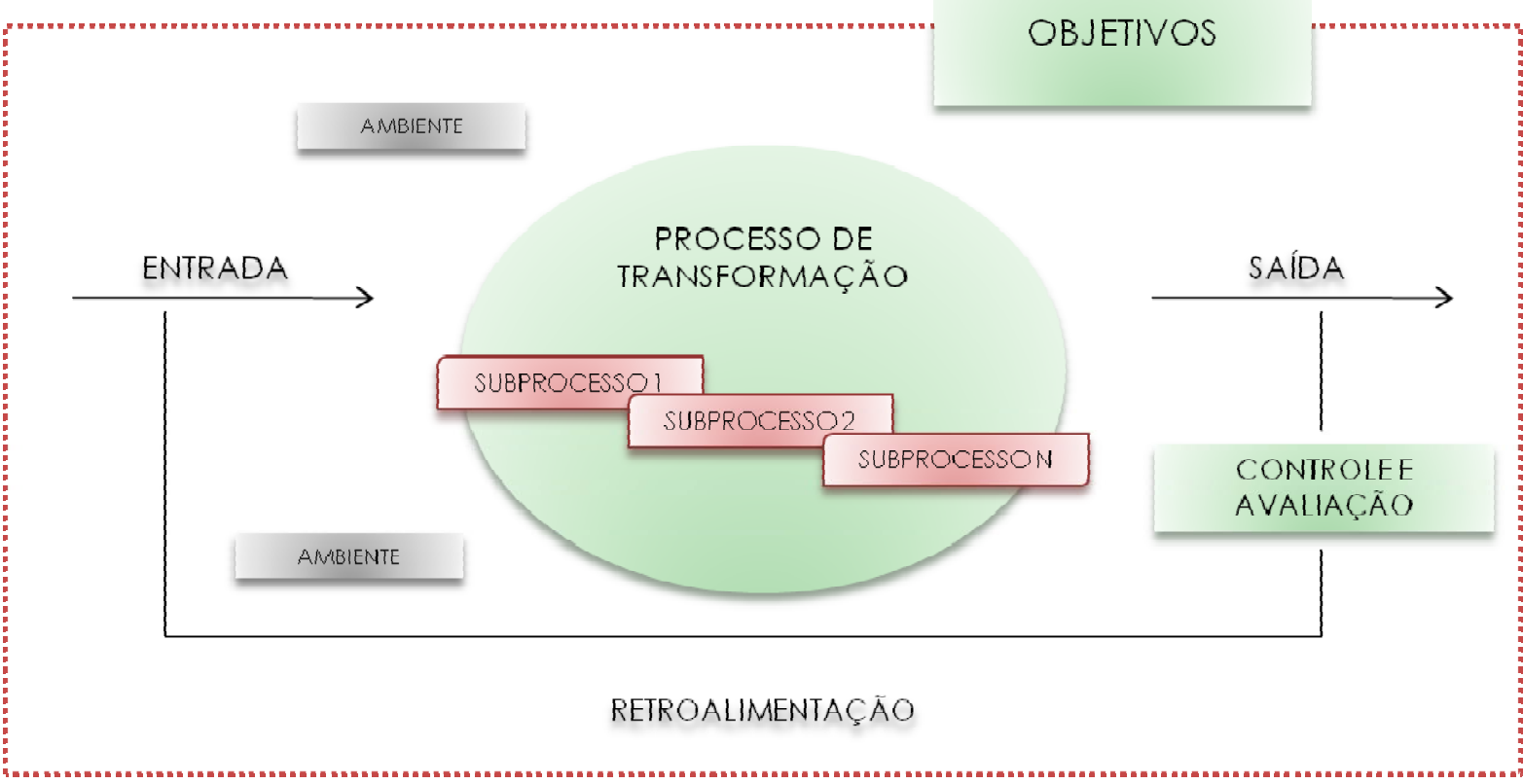

Fonte: Adaptado de Mendonça, 2001.

Figura 1 - Componentes de um sistema de produção

Os objetivos determinam a própria razão da existência dos sistemas e delimitam a finalidade deste. Na ótica da organização os sistemas devem ser planejados e coordenados para que proporcionem lucro máximo, enquanto que a função produção deve encarregar-se de atingir, por meio do processo produtivo e suas atividades, os objetivos da organização. Verifica-se ainda que o processo produtivo - ou de transformação - pode ser desmembrado em subprocessos. O objetivo de tal desmembramento é proporcionar o máximo de controle gerencial por fase ou etapa da produção.

Especificamente para a pecuária de corte, os sistemas têm por objetivo a produção de animais, nas suas diferentes fases. O conjunto de fases do desenvolvimento dos animais é denominado "ciclo de produção". A figura 2 ilustra o ciclo completo da produção da pecuária de corte e apresenta os pontos de transição entre as fases de desenvolvimento dos animais, nos quais são estabelecidas as possibilidades de comercialização dos produtos (MARION, 2007).

A primeira fase dita "cria", engloba os aspectos relacionados à reprodução, nascimento e desmama dos animais. A segunda é denominada "recria" e se ocupa na preparação dos animais para o retorno nas atividades da fase "cria" ou destinálos para a fase final do ciclo, denominada terminação ou "engorda". 


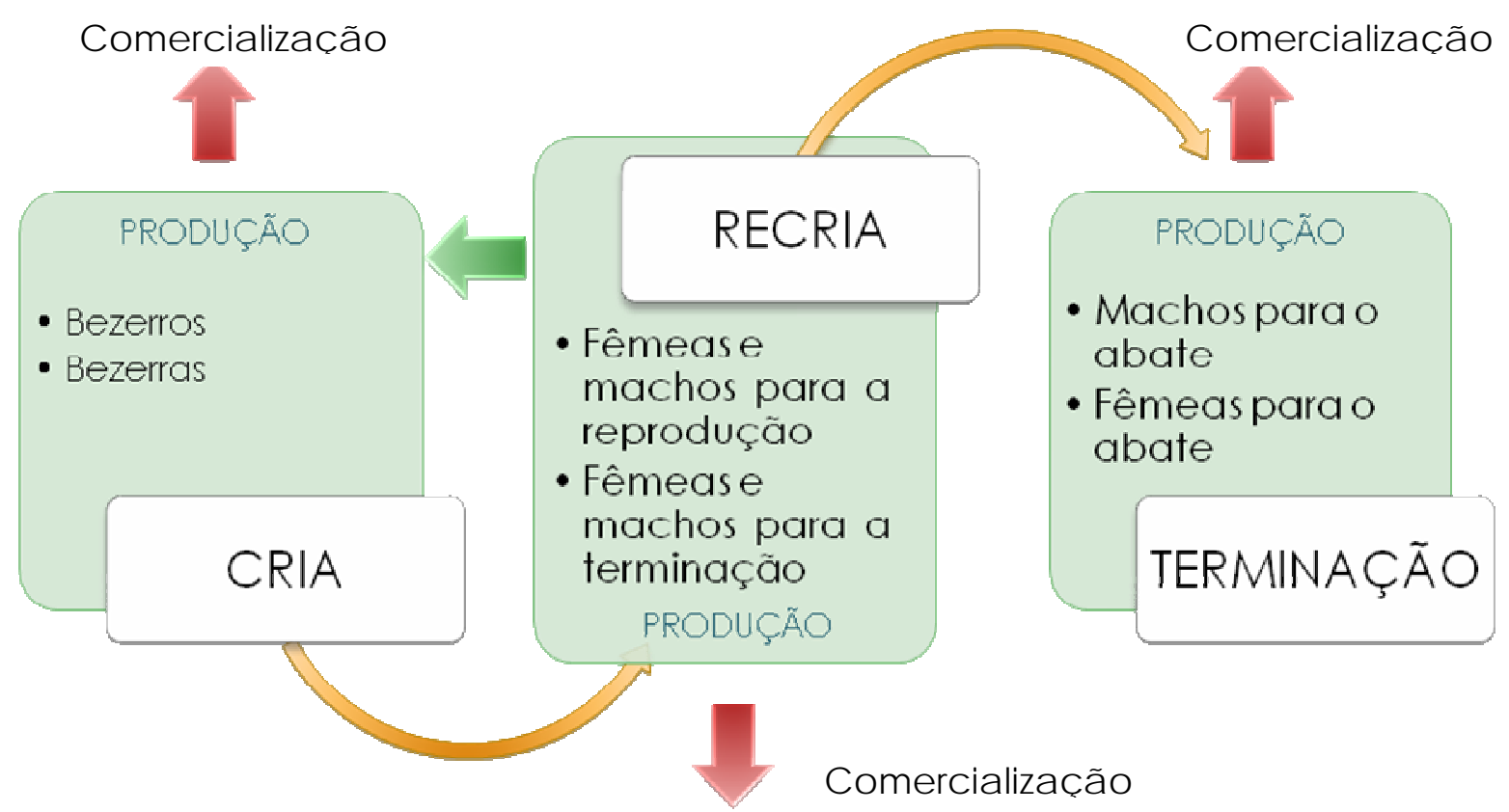

Fonte: Adaptado de Marion, 2007.

Figura 2 - Ciclo completo de produção de bovinos no Brasil

Segundo Cezar et al. (2005), cria, recria e engorda são atividades econômicas da pecuária de corte que, quando desenvolvidas combinadamente, complementam-se, conforme apresenta o quadro 1:

(Continua)

ATIVIDADES

CARACTERIZAÇÃO

Cria

Rebanho de fêmeas em reprodução, podendo estar incluída a recria de fêmeas para reposição, para crescimento do rebanho e para venda. Venda de todos os machos a desmama, em geral com 7 a 9 meses de idade. Comercialização de bezerras desmamadas, novilhas, vacas e touros. Em geral, as bezerras desmamadas e as novilhas jovens ( 1 a 2 anos) são vendidas para reprodução, enquanto as novilhas de 2 a 3 anos, as vacas e os touros descartados se destinam ao abate.

Cria e recria

Retenção de machos até 15 a 18 meses de idade (garrotes), quando então são comercializados.

Cria, recria e engorda

Considerada como atividade de ciclo completo, assemelha-se às anteriores, porém os machos são vendidos como bois gordos para abate, com idade de 15 a 42 meses. 


\begin{tabular}{|c|c|}
\hline ATIVIDADES & CARACTERIZAÇÃO \\
\hline Recria e engorda & $\begin{array}{l}\text { A atividade tem início com o bezerro desmamado e termina com o boi } \\
\text { gordo. Entretanto, em função da oferta de garrotes de melhor qualidade, } \\
\text { também pode começar com esse tipo de animal, o que, associado a } \\
\text { uma boa alimentação, reduz o período de recria/engorda. O mesmo } \\
\text { ocorre com bezerros desmamados de alta qualidade. Embora essa } \\
\text { atividade tenha predominância de machos, verifica-se também a } \\
\text { utilização de fêmeas. }\end{array}$ \\
\hline $\begin{array}{l}\text { Engorda } \\
\text { (terminação) }\end{array}$ & $\begin{array}{l}\text { Nas décadas passadas foi exercida pelos chamados "invernistas". Estes } \\
\text { se localizavam em regiões de boas pastagens e aproveitavam a grande } \\
\text { oferta de boi magro ( } 24 \text { a } 36 \text { meses de idade) da época. Atualmente, } \\
\text { encontra-se bastante restrita como atividade isolada, sendo } \\
\text { desenvolvida por um número reduzido de pecuaristas que também } \\
\text { fazem a terminação de fêmeas. Essa mudança de cenário deve-se à } \\
\text { expansão das áreas de pastagens cultivadas em regiões onde } \\
\text { tradicionalmente não existiam e, por consequência, à redução da oferta } \\
\text { de boi magro. }\end{array}$ \\
\hline
\end{tabular}

Fonte: Adaptado de Cezar et al., 2005.

Quadro 1 - Caracterização das atividades econômicas da pecuária de corte desenvolvidas de forma isolada ou complementar

A decisão sobre quais objetivos e as atividades desenvolvidas em um sistema de produção são fundamentais para a determinação da viabilidade econômica deste. É o ponto de partida para a definição do sistema de produção. Outra decisão importante é como serão utilizados os recursos da produção. A utilização das tecnologias de produção está relacionada ao processo de transformação que define e decide como os produtos serão produzidos. Em termos de operações, a lógica para o sistema de produção é que os conjuntos dos recursos de entrada previstos no sistema após interagirem apresentem saídas ou resultados desejáveis. As combinações possíveis das alternativas de produção que visam o aumento da eficiência do sistema, em termos biológicos são numerosas e fundamentam-se no grau de utilização destas.

Segundo Cezar et al. (2005), a dimensão continental do Brasil, a variedade de ecossistemas e a diversidade socioeconômica das regiões e dos produtores fazem com que a pecuária de corte brasileira apresente uma gama considerável de sistemas de produção. Propõem uma classificação com base nos regimes alimentares dos animais e considera como "pontos de corte": a) sistema extensivo regime exclusivo de pastagem; b) sistema semi-intensivo - pastagem mais 
suplementação em pasto; e c) sistema intensivo - pastagem mais suplementação em pasto e confinamento.

Segundo Marion (2007), algumas especificidades devem ser acrescentadas à classificação, conforme representado na figura 3 :

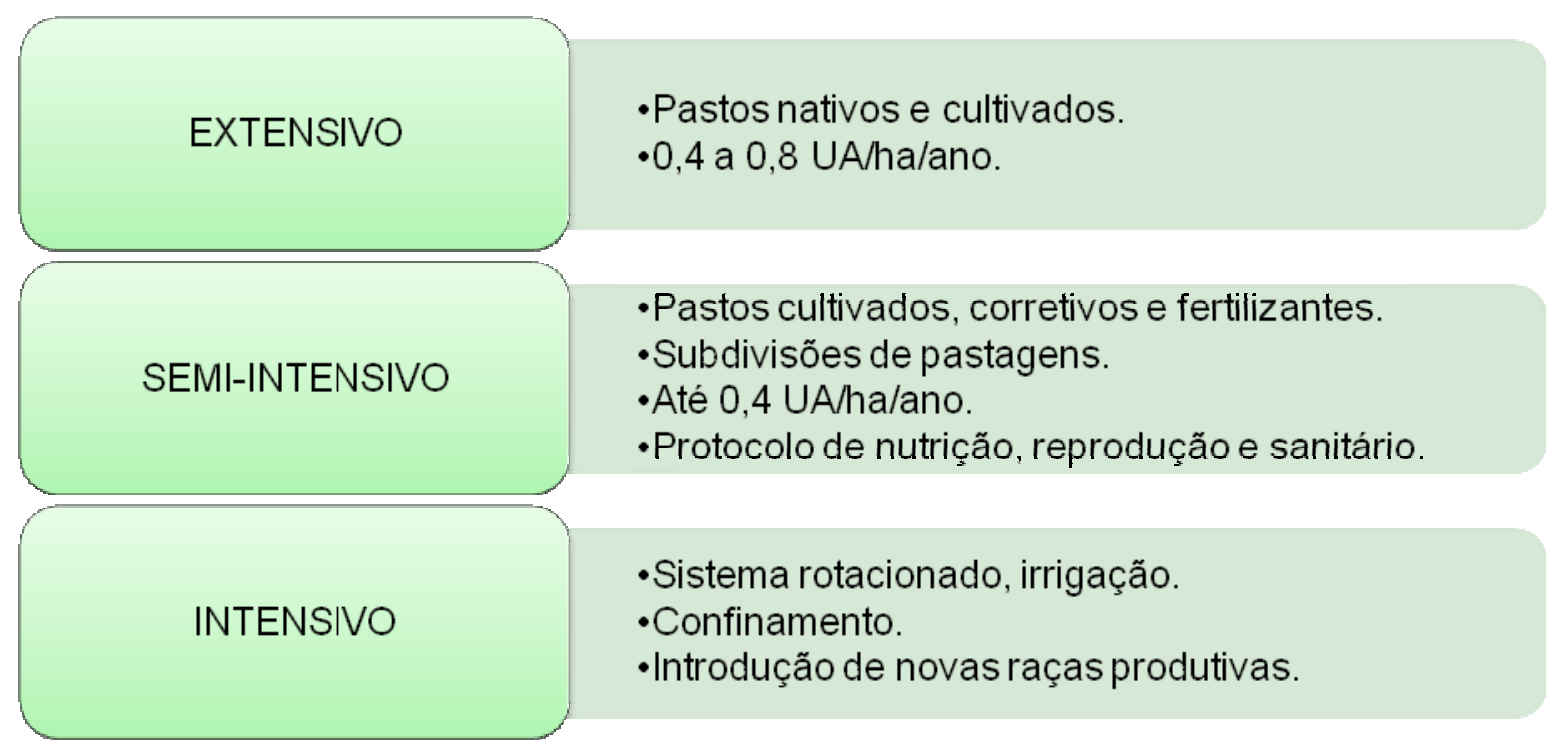

Fonte: Adaptado de Marion, 2007.

Figura 3 - Sistemas de produção e especificidades

Cada vez mais têm sido inseridos nesse sistema, especialmente no ambiente da produção, conhecimento e tecnologias. Assim, criam-se numerosas possibilidades de combinações e alternativas tecnológicas que, quase sempre, resultam em intensificação dos sistemas produtivos e tornam mais complexas as decisões, especialmente aquelas oriundas das interações entre os componentes biológicos e econômicos (EUCLIDES FILHO, 2000).

Para a elaboração do estudo de viabilidade de um sistema de produção pecuária de corte, torna-se necessário o correto dimensionamento dos aspectos relacionados às tecnologias de produção a serem adotadas. Segundo Rodrigues et al. (2010), um conjunto mínimo de aspectos devem ser contemplados (Figura 4). 


\begin{tabular}{|c|c|c|c|c|}
\hline Subprocesso & & ubprocesso 2 & \multicolumn{2}{|c|}{ Subprocesso 3} \\
\hline - CRIA & & - RECRIA & \multicolumn{2}{|c|}{ - TERMINAÇÃO } \\
\hline \multicolumn{5}{|c|}{ TECNOLOGIAS } \\
\hline Rebanho & Sanidade & Infraestrutura & Reprodução & Alimentaçāo \\
\hline \multirow{2}{*}{$\begin{array}{l}\text { Melhoramento } \\
\text { genético }\end{array}$} & \multirow{2}{*}{$\begin{array}{l}\text { Protocolo } \\
\text { sanitário oficial }\end{array}$} & Layout & \multirow{2}{*}{ Monta natural } & $\begin{array}{l}\text { Pastagens } \\
\text { cultivadas }\end{array}$ \\
\hline & & & & $\begin{array}{l}\text { Pastagens } \\
\text { adubadas }\end{array}$ \\
\hline \multirow{2}{*}{$\begin{array}{l}\text { Cruzamento } \\
\text { industrial }\end{array}$} & \multirow{2}{*}{$\begin{array}{l}\text { Protocolo } \\
\text { sanitário } \\
\text { específico }\end{array}$} & Rotacionada & \multirow{2}{*}{$\begin{array}{c}\text { Inseminaçăo } \\
\text { artificial }\end{array}$} & Mineralização \\
\hline & & Confinamento & & Suplementação \\
\hline
\end{tabular}

Fonte: Rodrigues et al., 2010.

Figura 4 - Tecnologias utilizadas para caracterização de um sistema de produção pecuária

O número e a abrangência dos aspectos tecnológicos envolvidos no sistema são importantes, pois se complementam e determinam os parâmetros de saída do processo produtivo e a viabilidade econômica do sistema. Desta forma pode-se dimensionar com melhor racionalidade a utilização, eficiência e retorno de investimentos nas atividades da produção pecuária (Figura 5).
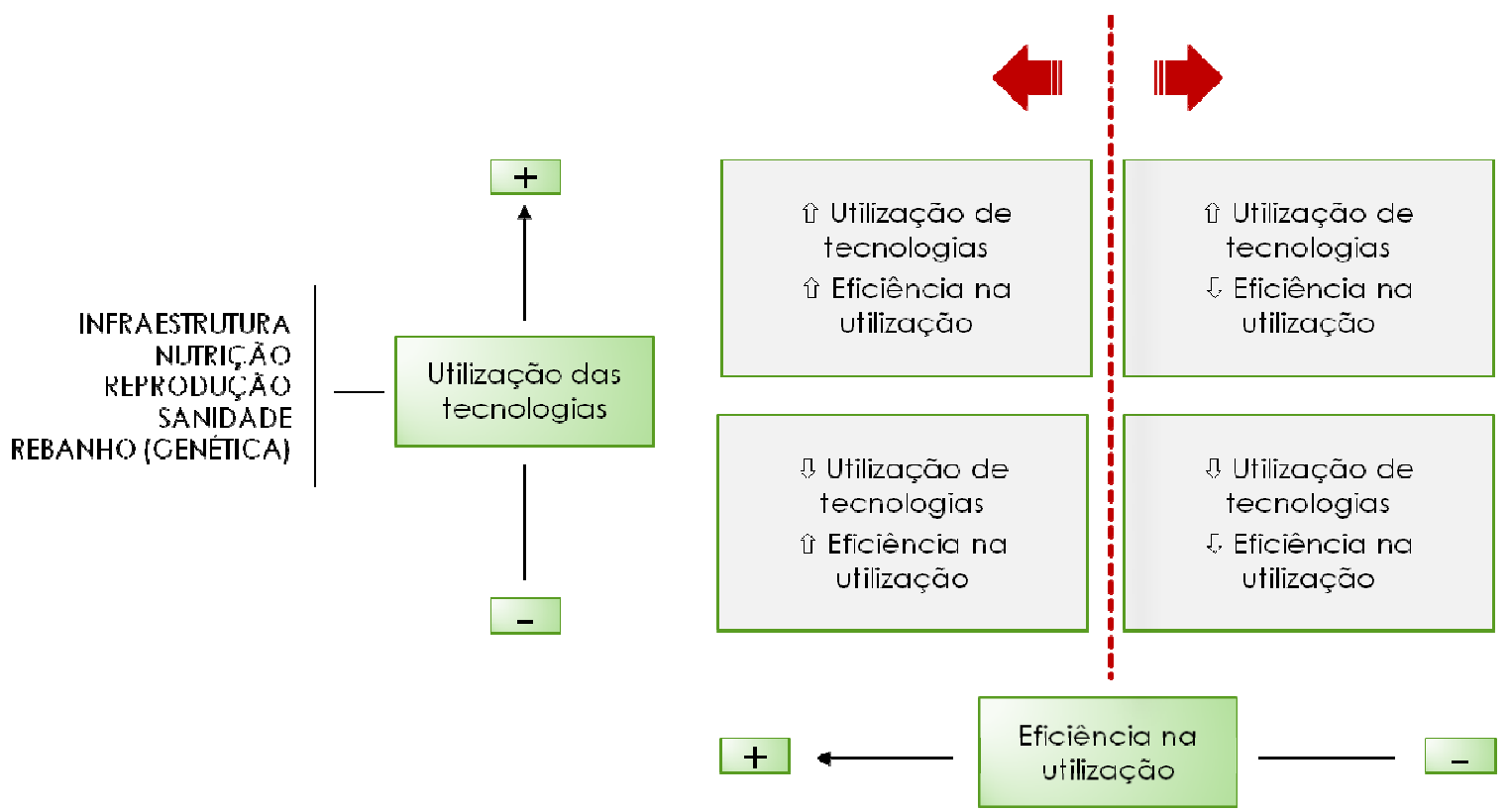

Fonte: Rodrigues et al., 2010.

Figura 5 - Aspectos tecnológicos e quadrantes resultantes da utilização e da eficiência da utilização das tecnologias de produção 
Se por um lado a utilização de novas tecnologias e a intensificação dos sistemas de produção invariavelmente aumentam os resultados em termos de produção, por outro exigem maiores gastos e aumento nos investimentos. Deve-se observar que a utilização das tecnologias disponíveis é necessária para o aumento da produção, porém o que define o alcance de resultados desejados é o grau de eficiência na utilização das tecnologias no sistema (Figura 5).

Segundo Gameiro (2009), é importante a distinção do termo eficiência no processo produtivo. Define que um processo produtivo é mais eficiente tecnicamente quando comparado a outros, quando obtém a mesma quantidade produzida com a menor quantidade de pelo menos um fator de produção, ceteres paribus ${ }^{10}$. A eficiência econômica é aquela obtida quando se produz a mesma quantidade de produto ao menor custo. Conclui que a máxima eficiência técnica não implica necessariamente na máxima eficiência econômica.

Desta forma o planejamento, a avaliação, o controle e o desempenho do processo produtivo devem abranger tanto a eficiência técnica quanto os resultados econômicos decorrentes das atividades do sistema de produção.

O conceito de desempenho utilizado neste trabalho relaciona-se ao conjunto de características ou capacidades de comportamento e rendimento: (i) do sistema produtivo e (ii) da evolução e manutenção do rebanho. A determinação do desempenho produtivo do sistema precede à análise econômica, assim devem-se transformar requisitos, metas e expectativas de desenvolvimento e evolução do rebanho - no sistema - em resultados numéricos, denominados índices.

Vários autores utilizam-se dos índices zootécnicos com diversos objetivos, a saber: (i) descrição dos níveis tecnológicos e de produtividade para contextualização da pecuária de corte (FÜRSTENAU, 2004; BRASIL, 2007; CARVALHO et al., 2007; CRISTHOFARI, 2007; ZILIO et al., 2007; BERNARDI et al., 2009; IGREJA et al., 2009;); (ii) determinação de parâmetros produtivos de sistemas de produção para execução de simulações (EUCLIDES et al., 1998; CORRÊA, et al., 2000; CEZAR, 2001; BERETTA et al., 2002; ABREU et al., 2003; ICHIHARA, 2003; MAYA, 2003; PERES et al., 2004; JORGE JÚNIOR et al., 2006; FIGUEIREDO et al., 2007; LORENZETTI et al., 2008; OAIGEN et al., 2009); (iii) determinação do comportamento de preços do rebanho (NUNES et al., 2001); e (iv) controle gerencial

\footnotetext{
${ }^{10}$ Também grafada coeteris paribus, é uma expressão do latim que pode ser traduzida por "todo o mais é constante" ou "mantidas inalteradas todas as outras coisas".
} 
da produção (CANZIANI et al., 1998). Nota-se nos trabalhos que a obtenção e classificação dos índices não são padronizadas e dependem de parâmetros e dos próprios índices zootécnicos adotados nessas classificações. De modo geral, eles podem ser analisados separadamente, fato também observado por Pinatti (2007).

No estudo de viabilidade proposto neste trabalho o importante é a determinação de quais são, o que expressam e como são obtidos os índices zootécnicos utilizados no desenvolvimento e evolução dos rebanhos considerados no sistema de produção, visto que os índices podem variar - e variam - de acordo com a configuração e características dos sistemas.

Segundo Pinatti (2007, p.18):

[...] Na literatura são apresentados valores de índices zootécnicos, porém, sem detalhamentos sobre a obtenção dessas informações. Em grande parte baseiam-se na experiência dos autores ou em informações de algumas propriedades pontuais. Em muitos casos são projeções ou atualizações de informações antigas. A gama de variação dos índices de produtividade do rebanho brasileiro é muito ampla, predominando os baixos índices na maioria das propriedades e, em uma minoria, valores iguais aos melhores encontrados em país de pecuária tecnificada. As causas principais dessa grande amplitude, bem como na maioria de baixos índices, relacionam-se ao não uso racional de tecnologias disponíveis e a ineficiência no gerenciamento nas propriedades produtoras.

Com vistas a essa afirmativa, podem-se utilizar as definições de Mendonça (2001), quando propõe que os indicadores de processos devem apresentar as relações entre as variáveis representativas destes, de modo que estas possam ser gerenciadas. Ainda Mendonça (2001) define indicador como a grandeza resultante da relação matemática entre duas ou mais medidas de desempenho, cujo objetivo é dimensionar o comportamento de um processo - inclusive seus resultados - para que possam ser comparados com padrões pré-estabelecidos. Destaca a importância da correta definição de: (i) medidas de desempenho: medições que quantificam o estado de um processo ou do resultado deste; (ii) índices: resultados numéricos obtidos a partir dos indicadores de um processo e (iii) padrões: valores particulares dos índices definidos como referencial para um processo.

A figura 6 ilustra uma estrutura genérica de um sistema de transformação do tipo input / output e três tipos de indicadores de processos: (i) indicador de produtividade $\left(\mathrm{I}_{\mathrm{P}}\right)$; indicador de qualidade $\left(\mathrm{I}_{\mathrm{Q}}\right)$ e indicador de capacidade $\left(\mathrm{I}_{\mathrm{S}}\right)$. Nota-se que os indicadores são obtidos com base em diferentes medidas de desempenho resultantes do processo de transformação. Pode-se utilizar este procedimento de 
obtenção do indicador tanto para os processos finalísticos quanto para os subprocessos de produção.

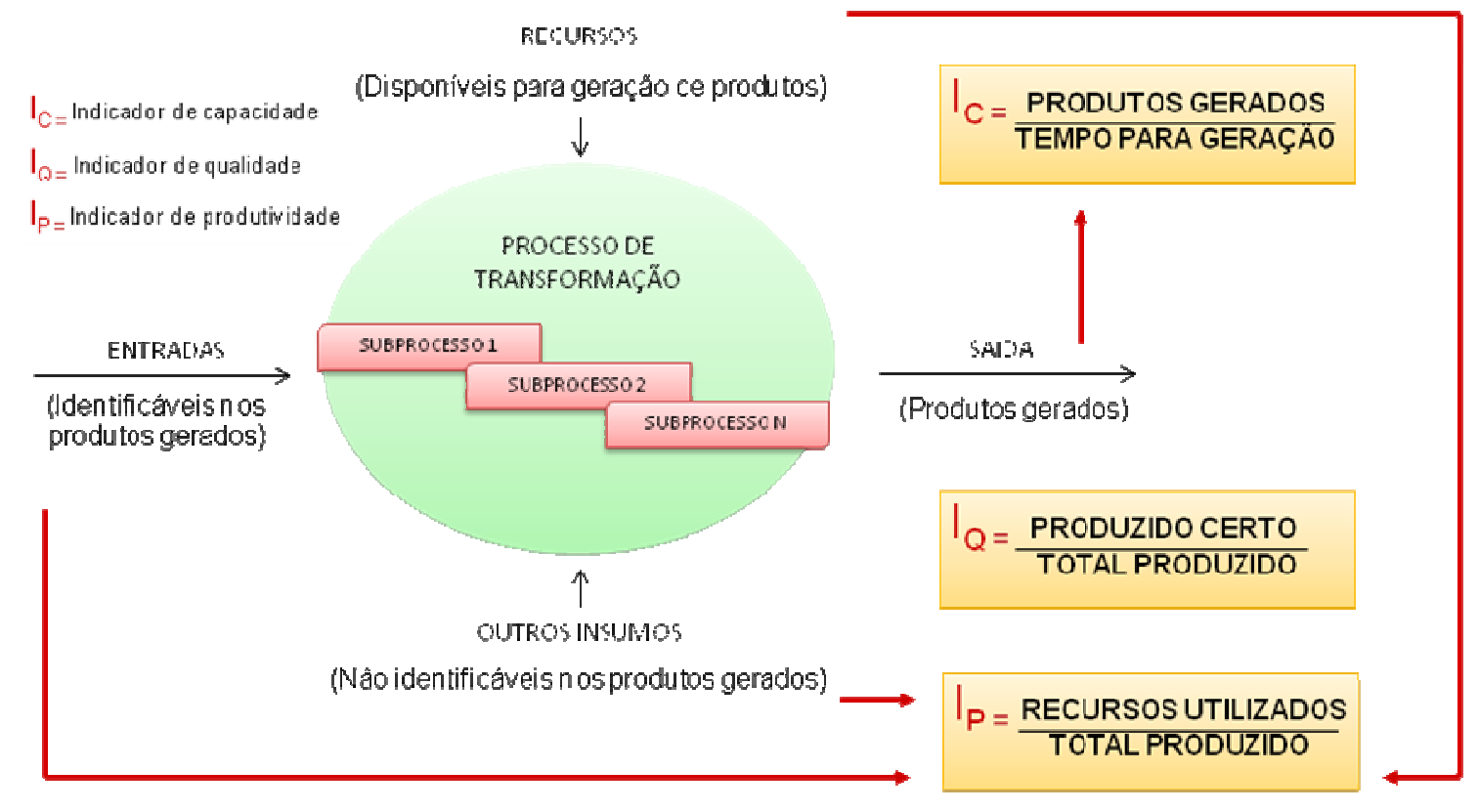

Adaptado de Mendonça, 2001.

Figura 6 - Diagrama detalhado de um processo e obtenção dos indicadores

Os indicadores de qualidade representam a proporção entre o que foi produzido em conformidade com os padrões requeridos e o total produzido. São representados pela expressão:

$$
I Q=\frac{\text { TOTAL DE CONFORMIDADES }}{\text { TOTAL PRODUZIDO }} \times 100
$$

O cálculo de um indicador da qualidade ocorre quando se apura a conformidade das saídas de um processo e se relacionam esses resultados com 0 volume ou quantidade processada. O resultado desta comparação pode ser mostrado a partir do percentual de não conformidade ou não adequação ou de forma inversa o percentual de conformidade ou adequação.

Para facilitar a compreensão, de acordo com o que apresenta a figura 6 , se o objetivo final do processo for produção de bovinos para o abate, os subprocessos podem ser - no caso de uma produção de ciclo completo - subprocesso 1 (cria); subprocesso 2 (recria) e subprocesso 3 (terminação). Para a organização um dos fatores críticos de sucesso é garantir a máxima produção de animais destinados à 
reposição. Um dos processos chaves então seria a produção de machos e fêmeas, no qual a atividade crítica seria a reprodução via monta natural ou por inseminação artificial. Se na prática de reprodução artificial com a utilização de um protocolo de inseminação em tempo fixo (IATF) for inseminado um total de 100 matrizes e após a inseminação - no ato do diagnóstico de prenhez dos animais - forem identificadas 70 matizes prenhes, tem-se:

$$
1 Q-\frac{70}{100} \times 100-70 \%
$$

O resultado aponta que o indicador de qualidade do processo de inseminação artificial é de $70 \%$. Como o indicador da qualidade demonstra desvios pode-se concluir que o processo - em teoria - pode melhorar em $30 \%$.

Já os indicadores da produtividade demonstram a competência no uso dos recursos necessários à produção de um bem ou serviço, conforme a expressão:

$$
I P=\frac{\text { TOTAL PRODUZIDO }}{\text { RECURSOS CONSUMIDOS }}
$$

Representam o resultado da relação entre as saídas (produtos e/ou serviços) de um processo e os recursos utilizados (consumidos e/ou usados) para sua produção.

Utilizando-se o mesmo exemplo da IATF, analisando o trabalho de um profissional que esteja realizando a operação e supondo-se que 2 profissionais inseminarão 20 matrizes em 1 hora de trabalho, tem-se:

$$
I P=\frac{20}{\frac{2 \text { funce }}{1 \text { hora }}}=10
$$

O resultado aponta que o índice de produtividade é de 10 matrizes inseminadas por profissional por cada hora trabalhada.

Observa-se que o resultado deste indicador não é representado em forma de percentual e sim pela relação entre as duas medidas de desempenhos distintas 
entre si. Vale ressaltar que todo indicador de produtividade está sempre ligado à utilização de um determinado recurso empregado na geração de um bem ou serviço, daí ser ele de fundamental importância para gestão do uso deste recurso. O indicador de produtividade também pode ser representado como recursos utilizados por total produzido, que é o inverso do caso acima mostrado. Pode-se utilizar este raciocínio quando do tratamento de medidas financeiras, por exemplo: 20 U.M. ${ }^{11}$ por matriz inseminada.

Os indicadores de capacidade ou saída representam a quantidade de produtos e/ou serviços gerados em um determinado período de tempo. É o que normalmente se chama de Produção ou Geração, conforme representa a expressão:

$$
I C=\frac{\text { TOTAL PRODUZIDO }}{\text { TEMPO DE REALIZAÇAOO }}
$$

Os indicadores de capacidade ou saída relacionam uma determinada produção realizada em um intervalo de tempo. No exemplo, se forem inseminadas 150 matrizes por turno de 10 horas de trabalho, tem-se:

$$
\text { IC }=\frac{150}{10}=15
$$

Logo tem-se 15 matrizes inseminadas por hora, o que não avalia a utilização de recursos e sim do tempo utilizado na prática.

Adotadas as devidas adequações para a Zootecnia, poder-se-ia utilizar os três tipos de indicadores - qualidade, produtividade e capacidade - para uma melhor compreensão, sistematização e comparação entre os trabalhos realizados na área, especialmente no que se refere aos estudos de viabilidade desenvolvidos para bovinocultura de corte.

\footnotetext{
${ }^{11}$ U.M. significa unidade monetária.
} 


\subsection{Estudos de viabilidade}

Várias são as definições sobre estudos de viabilidade, porém a maioria senão a totalidade dos autores - concorda que estes são parte integrante no contexto de um empreendimento ou projeto de investimento.

Usualmente utilizado em Engenharia e difundido no ambiente industrial a partir de meados do século $X X$, definiu-se tradicionalmente o termo "estudo de viabilidade" - ou "anteprojeto" - como um estudo de viabilidade com grau de profundidade tal que permita indicar, para uma decisão, os parâmetros necessários ao início dos projetos de engenharia para determinada empresa com intenções básicas de expansão, implantação ou modificação de uma unidade industrial (CASAROTTO FILHO, 2009).

Nota-se que essa abordagem - utilizada para o setor industrial e para a área de Engenharia - pode ser utilizada nas áreas de Economia e Administração e, realizados os devidos ajustes para este trabalho, na área de Zootecnia.

Outra questão importante refere-se à terminologia utilizada. Segundo Jones $^{12}$ (1990 apud CASAROTTO FILHO, 2009, p. 7),

[...] palavras ou expressões idiomáticas estrangeiras, nem sempre comunicam de modo adequado o ato ou pensamento. É o caso da palavra projeto. Ainda recentemente, projeto era um termo técnico de Engenharia e projetar, um verbo utilizado por engenheiros. Hoje, todavia, no Brasil (inclusive em língua oficial) passou-se a denominar projeto ao estudo de viabilidade técnica, econômica e financeira de um empreendimento.

O quadro 2 apresenta uma comparação de denominações adotadas nos Estados Unidos, França, Brasil.

\begin{tabular}{lll}
\hline \multicolumn{1}{c}{ EUA } & \multicolumn{1}{c}{ França } & \multicolumn{1}{c}{ Brasil } \\
\hline Feasibility study & Étude de faisabilité & Estudo de viabilidade / Anteprojeto/ Projeto de investimento \\
Basic-design & Avant-projet & Engenharia básica \\
Detailed-design & Projet & Engenharia de detalhe \\
\hline
\end{tabular}

Fonte: Adaptado de Jones (1990 apud CASAROTTO, 2009, p. 14).

Quadro 2 - Comparação de denominações em projetos

${ }^{12}$ JONES, A.M. Serviços de engenharia. 2 ed. Rio de Janeiro: LTC, 1990. 
Ainda Casarotto Filho (2009, p.X) argumenta que a terminologia é utilizada de várias maneiras e de acordo com a ótica de quem lida com o assunto:

[...] Plano de negócios para quem lida com empreendedorismo; Projeto de Investimento para economistas e técnicos de bancos de desenvolvimento; Estudo de Viabilidade ou, por vezes, Anteprojeto, para o Engenheiro, já que o mesmo diz que projeto é algo em condições de ser executado, pois, na sequência, ainda vem o Projeto Básico e o Projeto Detalhado; em suma, o nome não importa tanto. O importante mesmo é que se tenha uma ferramenta para a tomada de decisão, notadamente em implantações e expansões de empresas e o balizamento dos parâmetros para início dos projetos de engenharia propriamente ditos.

Nota-se a ênfase dada pelo autor no objetivo esperado da realização do estudo que é a tomada de decisão - no presente - sobre a realização de uma ação futura. Também enfatiza Clemente ${ }^{13}$ (1998, apud MEIRELES 2004, p.12), quando definem que "o termo projeto de investimento faz menção à execução de algo no futuro para atender à necessidades ou oportunidades".

A questão dos objetivos é importante - tanto para o entendimento e delimitação do tema - quanto para responder o problema que este trabalho se propõe. Desta forma, tanto na atividade de pesquisa zootécnica - quando realizada por Instituições de Ensino Superior Públicas, ditas organizações sem fins lucrativos - quanto na produção comercial - sob a responsabilidade das organizações com fins lucrativos - a definição dos objetivos deve ser contemplada, pois se refere aos resultados esperados de algum tipo de esforço, ação ou decisão, que envolve a utilização de recursos.

$\mathrm{Na}$ perspectiva da empresa com fins lucrativos e em relação à restrição econômica e orçamentária, vários autores ponderam a utilização de ferramentas para a tomada de decisão, a saber:

Gitman (1997) propõe que a avaliação e seleção dos investimentos em longo prazo sejam coerentes com o objetivo da empresa de maximizar a riqueza dos seus proprietários.

Segundo Gitman (1997, p.290), uma empresa pode decidir investir por vários motivos. A expansão, usualmente realizada por meio da aquisição de ativos imobilizados, é um dos motivos mais comuns para o dispêndio de capital. Uma

${ }^{13}$ CLEMENTE, A. (Org). Projetos empresariais públicos. São Paulo: Atlas, 1998. 341p. 
empresa em crescimento normalmente precisa investir capital em infraestrutura para pode elevar o nível de operações e produção. Ainda argumenta que detalhamento da etapa de avaliação e análise precede a decisão, portanto a importância desta etapa é crucial para quem vai decidir:

[...] As propostas são formalmente avaliadas (1) para se assegurar de que elas são apropriadas tendo em vista os objetivos e planos globais da empresa e, o mais importante (2) para verificação da sua viabilidade econômica. Os custos e benefícios propostos são estimados e então convertidos em uma série de fluxos de caixas relevantes, aos quais várias técnicas de orçamento de capital são aplicadas para aferir o mérito do investimento associado ao potencial de desembolso. Além disso, os vários aspectos de risco inerentes à proposta são incorporados à análise econômica ou classificados e agregados às mensurações econômicas. Uma vez concluída a análise econômica, um relatório sintético, frequentemente com uma recomendação, é submetido aos responsáveis pela tomada de decisão.

Melnick (1981) afirma que o projeto de investimento deve ser posto à prova do crivo da economia. Tal aspecto deve ser contemplado porque não ocorrem sem a definição do meio econômico, para qual deve contribuir. Portanto a investigação sistemática do projeto de investimento deve considerar a apreciação da economia, ao invés de abandoná-la às formas intuitivas da percepção.

Sandroni (2000) define investimento como o ato de incorrer em custos imediatos, na expectativa de retornos futuros.

Maximiano (2002) define projeto como uma atividade finita - ou temporária, com começo meio e fim - e não rotineira à organização, que tem por objetivo o fornecimento de um produto singular, dentro de restrições orçamentárias.

Hoji (2004) propõe que as decisões de investimento comprometem recursos da empresa por um período longo, sendo seu retorno efetivo estimado no presente, o que gera incertezas. A necessidade da análise da viabilidade econômica de um investimento gera um problema de engenharia econômica. A alternativa de investimento deve utilizar os métodos de análise econômica para melhor sustentar as decisões.

Woiler e Mathias (2008) propõem que projetos de investimento buscam simulações para o investimento e suas possíveis implicações.

Desta forma, a lógica para as entidades com fins lucrativos é a produção e comercialização de produtos/serviços que garantam a geração de caixa suficiente 
para cobrir os custos e despesas operacionais e amortizem os custos do projeto implantado. A partir deste ponto obtêm-se valor econômico, também conhecido como valor para os acionistas.

Porém na perspectiva das entidades organizacionais sem fins lucrativos, Cohen e Grahan (2002, p.4) argumentam:

[...] os que trabalham em entidades sem fins lucrativos ou em organizações não governamentais terão de traduzir alguns termos, a fim de infundir a idéia de valor para os acionistas em seus projetos. Sugerimos substituir mentalmente os termos valor para os stakeholders $^{14}$, valor para o contribuintes ou valor para os eleitores pelos termos valor para o acionista e valor econômico (que usamos como sinônimos).

Assim, o valor para uma entidade sem fins lucrativos pode não envolver lucro, porém implica necessariamente em resultado monetário que recupere os custos implícitos e explícitos do capital consumido pelo projeto.

Conclui-se que o estudo de viabilidade é o conjunto de informações que antecede à execução de um projeto e tem por objetivo auxiliar o processo de tomada de decisão para um empreendimento. E em qualquer das perspectivas - entidades com ou sem fins lucrativos - a apreciação da economia, na tomada de decisão é fundamental para o sucesso do empreendimento.

Situado o tema estudo de viabilidade dentro do projeto de investimento, torna-se necessário à definição das suas etapas.

De acordo com Buarque (1991), as etapas básicas que compõe os projetos de investimento genéricos são: (i) estudo do mercado; (ii) estudo do tamanho e localização; (iii) engenharia; (iv) análise de custos e receitas e (v) avaliação da viabilidade econômica.

Balarine (1997) expõe um método objetivando verificar previamente a viabilidade econômico-financeira das incorporações imobiliárias, num momento anterior à tomada de decisão por implantar (ou não) o projeto, a saber: (i) estudo prévio; (ii) projetos; (iii) pré-construção; (iv) construção; (v) vendas; (vi) ocupação e transferência.

Brito (2006) descreve a elaboração por fases: (i) primeira fase: ideia abalizada; (ii) segunda fase: estudos preliminares que se fazem com os primeiros

${ }^{14}$ Stakeholders são os interessados e impactados direta ou indiretamente pelos resultados da entidade organizacional. 
contatos com empresas, bancos e órgãos do governo; (iii) terceira fase: monta-se o anteprojeto $^{15}$; (iv) quarta fase: projeto definitivo, que foi reelaborado e aprovado; (v) executa-se dos trabalhos de ergonomia e de engenharia, montagem e instalações; (vi) sexta fase: acompanha-se o projeto.

Casarotto Filho (2009) propõe um modelo específico para a área industrial baseado na abrangência histórica dos componentes de um estudo de viabilidade, a saber: (i) estudo de mercado; (ii) estudo de localização; (iii) estudo de engenharia; (iv) estudo do tamanho; (v) estudo econômico-financeiro.

Independente dos setores, áreas de atuação e do momento da realização da análise econômica nota-se que estas são parte integrante dos estudos de viabilidade para todos os empreendimentos. Desta forma não seria diferente para a administração de projetos de empreendimentos destinados à produção animal.

Observadas as particularidades da produção destes e uma vez definida a necessidade de se proceder ao estudo de viabilidade, passa-se - no próximo item ao tratamento específico dos métodos de análise econômica.

\subsection{Métodos de análise econômica}

Os métodos tradicionais de análise econômica podem ser classificados de acordo com a origem dos dados: (i) métodos baseados em dados contábeis e (ii) métodos baseados em fluxos de caixa.

Os métodos baseados em dados contábeis referem-se à Demonstração do Resultado do Exercício $\left(D^{2} E^{16}\right)$. A DRE expõe o lucro conforme as operações são realizadas pela empresa e o lançamento contábil é realizado de acordo com o fato gerador do evento. Desta forma as receitas, as despesas e os custos devem ser registrados conforme sua ocorrência e não somente no momento da realização financeira. A esse conceito dá-se o nome de regime de competência (SOUZA, 2006).

\footnotetext{
${ }^{15} \mathrm{O}$ autor define o anteprojeto como o "projetos" em sua primeira versão. Seria um estudo amplo, sujeito a críticas e reformulações.

${ }^{16}$ DRE é uma demonstração contábil que, por meio do confronto das receitas, custos e despesas, evidencia a formação do resultado líquido em um exercício. São apuradas de acordo com o princípio contábil de competência.
} 
Os métodos que se baseiam nas Demonstrações de Fluxo de Caixa (DFC ${ }^{17}$ ) demonstram os recebimentos e os pagamentos durante determinado período de tempo, sendo assim fluxos de entradas e saídas. Portanto, a DFC é elaborada sob o regime de caixa, pois somente serão evidenciados nessa demonstração os movimentos que impactarem no caixa ou, de forma mais abrangente, nas disponibilidades da empresa (SOUZA, 2006).

Cria-se assim uma questão na qual se deve eleger qual a informação a ser utilizada para permitir ao investidor - ou credor, dependendo da situação - a determinação do valor esperado para o retorno dos seus investimentos e tomada de decisão.

Tanto quanto um quanto o outro método (DRE ou DFC): (i) apresentam funções específicas; e (ii) limitações na utilização e avaliação de resultados, conforme concluiu Souza (2006). Um aspecto central que os diferencia e que é importante para a utilização dos métodos que se baseiam em DFC é a depreciação. A depreciação não é fluxo de caixa quando utilizada para fins de imposto de renda ${ }^{18}$ e tributação da atividade rural exercida para firmas individuais (pessoa física).

Segundo Lustosa ${ }^{19}$ e Santos (2005 apud Souza, 2006, p.17), “... a despesa de depreciação integra o lucro contábil, mas não faz parte do fluxo de caixa operacional (FCO)". Também corroboram com a afirmativa Lopes e Martins ${ }^{20}$ (2005 apud Souza, 2006, p.17).

O lançamento sistemático de uma parcela do custo dos ativos permanentes contra as receitas anuais é um direito que as empresas têm para fins de diminuição dos lucros tributáveis. Segundo Gitman (1997, p.77):

[...] O administrador financeiro está mais preocupado com os fluxos de caixa do que com os lucros líquidos apurados na demonstração do resultado. Para ajustar a demonstração do resultado e obter o fluxo de caixa das operações, todas as despesas não desembolsáveis devem ser acrescentadas de volta aos lucros

\footnotetext{
${ }^{17}$ O fluxo de caixa - do inglês "cash flow" - refere-se ao montante de caixa recebido e gasto por uma empresa durante um período de tempo definido.

18 Para melhor esclarecimento sobre o assunto sugere-se acesso às instruções normativas específicas. Ver SRF $17 / 96$.

${ }_{19}$ LUSTOSA, P.R.B.; SANTOS, A. Proposta de integração plena do balanço e da demonstração do resultado com a demonstração dos fluxos de caixa por atividades: Teoria e exemplos práticos. In: ENCONTRO NACIONAL DOS PROGRAMAS DE PÓS-GRADUAÇÃO EM ADMINISTRAÇÃO EMPAD, 29, 2005, Brasília. Anais... Brasília: ANPAD, 2005, CD-ROM.

${ }^{20}$ LOPES, A.B.; MARTINS, E. Teoria da contabilidade - Uma nova abordagem. São Paulo: Atlas, 2005.
} 
líquidos da empresa depois do imposto de renda. Itens não desembolsáveis são despesas lançadas na demonstração do resultado, as quais não envolvem uma efetiva saída de caixa durante o período. Exemplo disso são as deduções por depreciação, amortização e exaustão.

Dados os conceitos, as definições, e os aspectos relevantes dos métodos de análise econômica, explorar-se-ão os métodos de análise econômica baseados nos métodos dos fluxos de caixa, por serem esses pertencentes ao escopo desta pesquisa.

\subsection{Métodos de análise econômica baseados em fluxos de caixa}

O primeiro aspecto a ser esclarecido para a utilização do método de fluxo de caixa, é que este se baseia no conceito contábil do regime de caixa e não no regime de competência. Assim são contempladas as entradas e saídas de caixa no momento no qual estas ocorrem.

O fluxo de caixa refere-se ao montante de unidades monetárias recebidas e gastas durante um período de tempo definido. Graficamente pode ser representado pela figura 7:

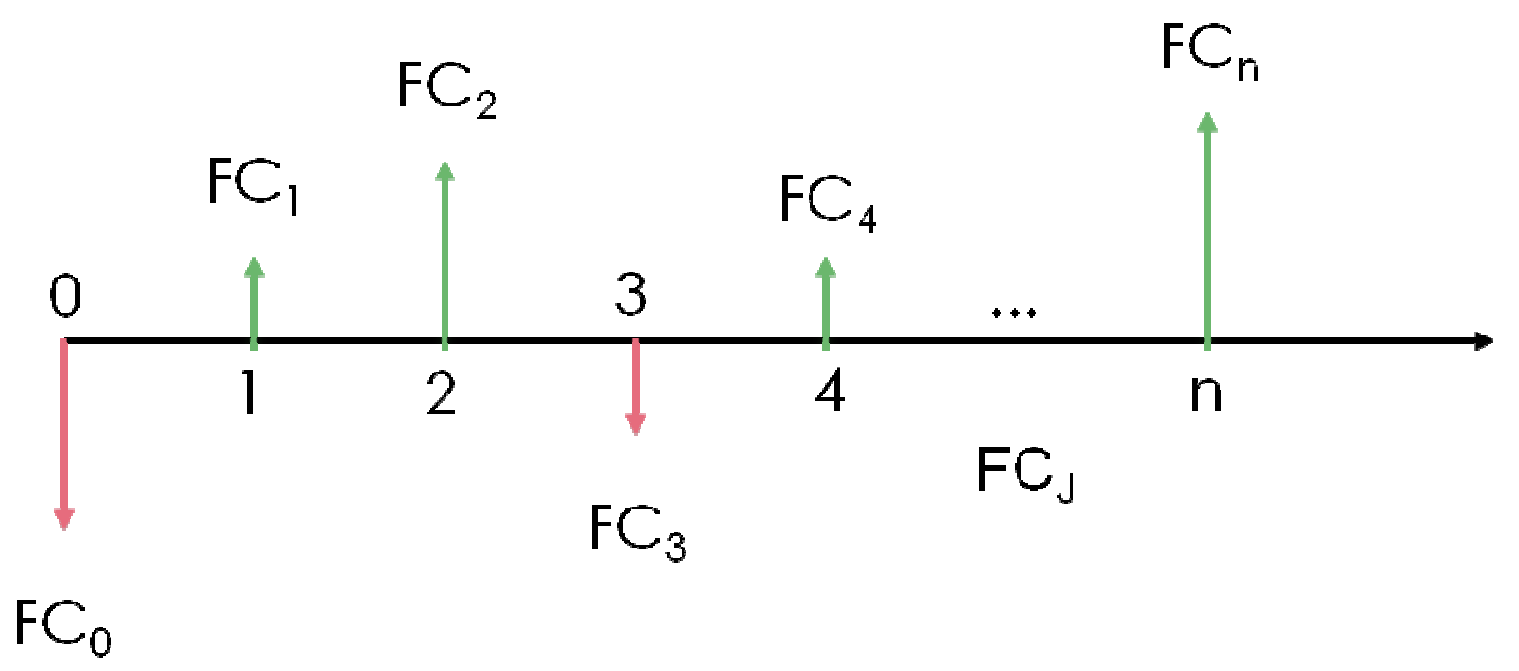

Figura 7 - Representação gráfica de um fluxo de caixa 
A unidade de tempo encontra-se no eixo horizontal do diagrama. A data inicial de ocorrência dos fluxos é representada pelo número 0 enquanto que $n$ representa o horizonte final do período. Verticalmente encontram-se as entradas e saídas líquidas de caixa. Assim $\mathrm{FC}_{1}, \mathrm{FC}_{2}$ e $\mathrm{FC}_{\mathrm{n}}$, apresentam valores de entrada de caixa maiores que os valores de as saídas de caixa, enquanto que $\mathrm{FC}_{0}, \mathrm{FC}_{3}$ e $\mathrm{FC}_{\mathrm{j}}$, representam valores de saídas de caixa maiores que os valores de entradas de caixa.

Os fluxos de caixa podem ser classificados de acordo com o resultado entre as entradas e saídas de caixa. Segundo Gitman (1997) e Barbieri et al. (2007), os fluxos de caixa são ditos "convencionais" quando ocorre no tempo 0 uma única saída de caixa, gerando um FC $_{0}$ negativo e nos demais períodos ocorrem fluxos de caixa positivos, conforme apresenta a figura 8 :

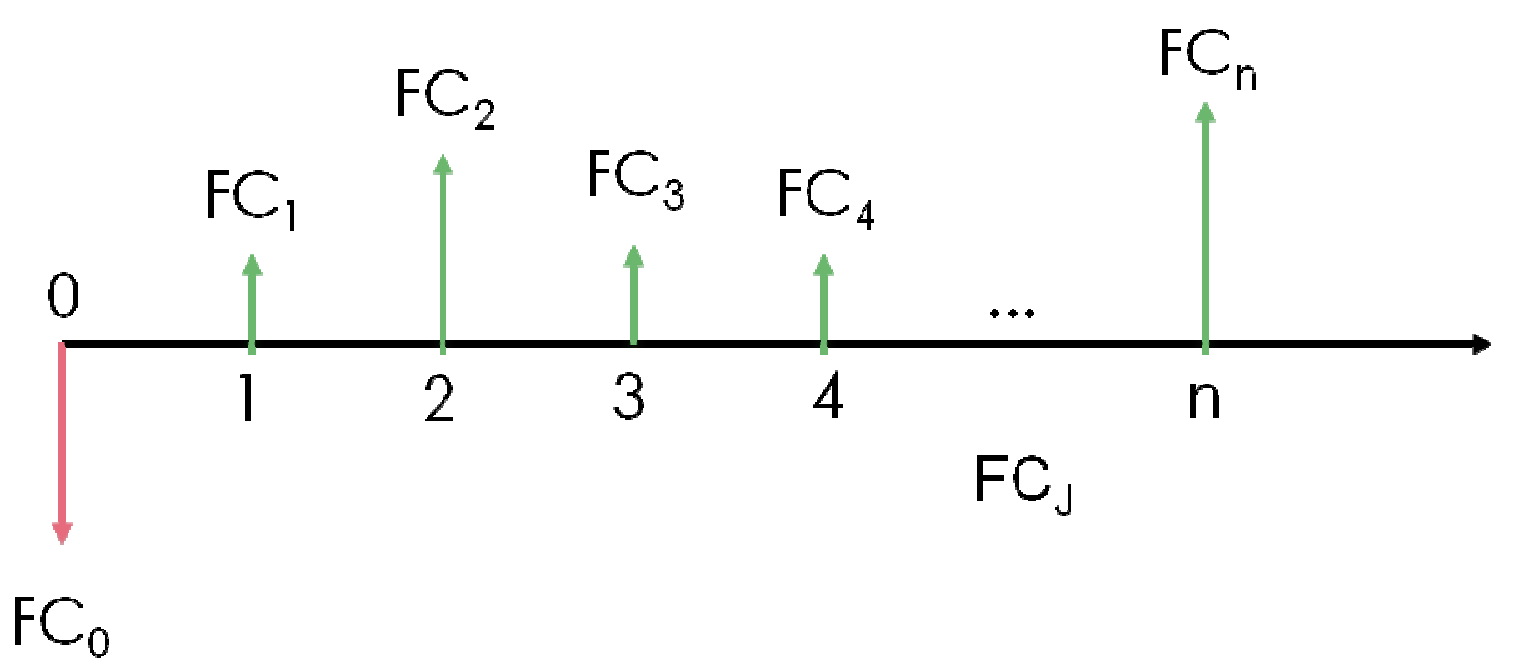

Figura 8 - Representação gráfica de um fluxo de caixa convencional

Os mesmos autores classificam os fluxos de caixa ditos "não convencionais" como os que apresentam uma saída inicial de caixa gerando um FC $_{0}$ negativo e nos demais períodos ocorrem fluxos de caixa positivos e negativos de forma não uniforme, conforme apresenta a figura 9: 


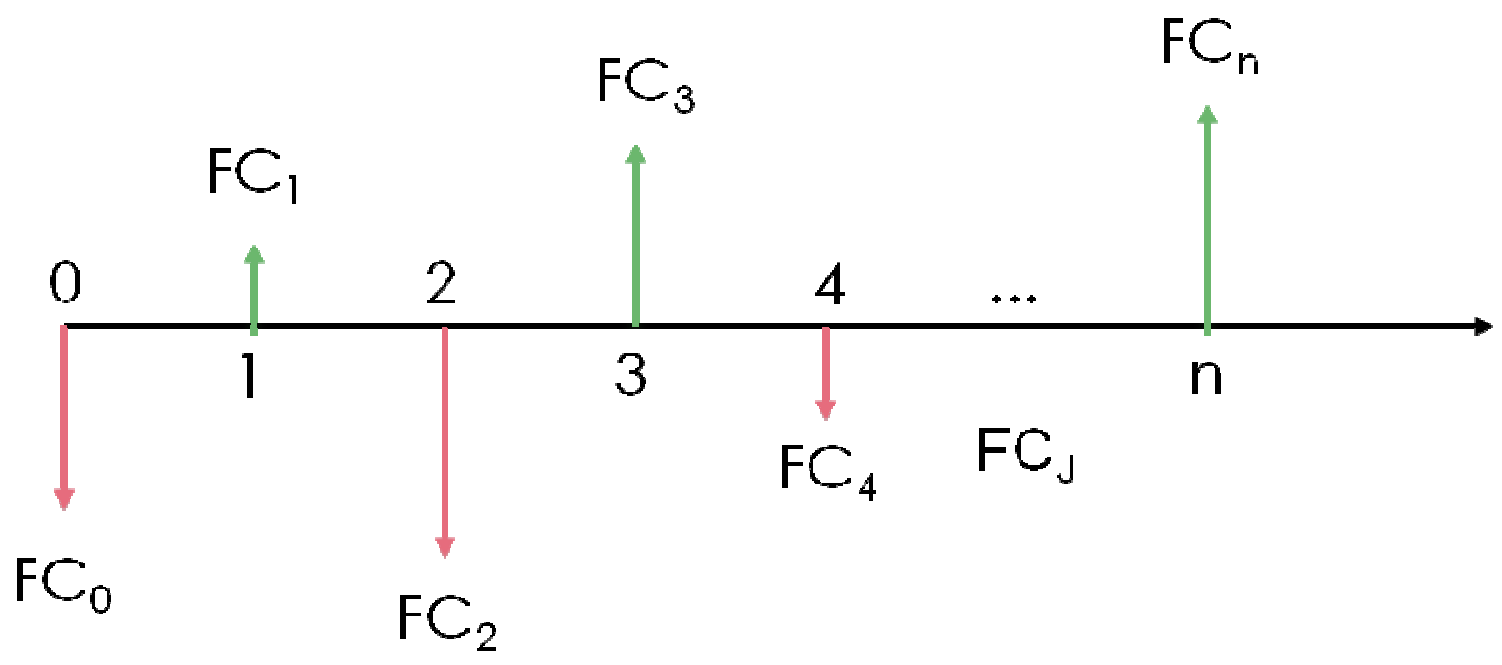

Figura 9 - Representação gráfica de um fluxo de caixa não convencional

Normalmente a unidade de tempo dos fluxos de caixa é denominada "período" e pode ser expressa em dia, mês, ano, dependendo da conveniência da elaboração do fluxo. Bordeaux-Rêgo et al. (2006, p.32), definem essa classificação como vida útil do projeto e justificam:

[...] A vida útil deve levar em consideração o tempo em que a concorrência demora em entrar no mercado e derrubar as margens e o potencial de crescimento. Reflete a vida econômica ou obsolescência, respectivamente, dos equipamentos iniciais do projeto, do bem ou serviço produzido. Pode contemplar, por exemplo, o prazo legal de uma concessão.

Segundo Brito (2006), a projeção de resultados até 10 anos é o período de referência considerado como bom horizonte de vida - para a análise de um projeto pelo BIRD ${ }^{21}, \mathrm{BID}^{22}, \mathrm{BNDES}^{23}, \mathrm{BNB}^{24}$.

Para Gitman (1997), a vida útil ${ }^{25}$ dos projetos pode afetar significantemente o padrão dos fluxos de caixa. Contudo pondera que a decisão deve ser embasada na observância das exigências da legislação pertinente ao assunto, que diz respeito ao cálculo da depreciação dos ativos de produção.

\footnotetext{
${ }^{21}$ Banco Internacional para Reconstrução e Desenvolvimento.

22 Banco Interamericano de Desenvolvimento.

${ }^{23}$ Banco Nacional do Desenvolvimento.

${ }^{24}$ Banco do Nordeste.

${ }^{25} \mathrm{O}$ autor considera o período de tempo no qual um ativo é depreciado.
} 
Nota-se que a depreciação é um aspecto importante na natureza das DFC, conforme referenciado por Souza (2006), Bordeaux-Rêgo et al. (2006), Brito (2006) e Gitman (1997).

Em relação aos componentes, o fluxo de caixa de qualquer projeto, que possua padrão convencional, pode incluir três componentes básicos: (i) investimentos iniciais (investimentos fixos, despesas pré-operacionais e capital de giro inicial), (ii) entradas de caixa operacionais (entradas de caixa incrementais após impostos) e (iii) o fluxo de caixa residual (fluxo de caixa não operacional, decorrente da liquidação do projeto). Todos os projetos - expansão, substituição, modernização e outros - têm os dois primeiros componentes. Alguns podem não contemplar o fluxo de caixa residual (GITMAN, 1997).

Outro aspecto importante para a utilização do método de fluxo de caixa é que este pode ou não considerar a remuneração do capital - que são os juros conforme apresenta Shinoda (2008, p.47):

[...] O conceito de valor do dinheiro no tempo embasa a técnica de fluxos de caixa descontados. As técnicas baseadas em fluxos de caixa descontados foram desenvolvidas considerando o conceito de valor do dinheiro no tempo. O conhecimento de juros compostos, a base para operar esse conceito, segundo Parker $^{26}$ (1968), vem da antiga Babilônia (1800 - 1600 A.C.) Embora se tenha notícia da aplicação do valor presente em 1540 (LEFLEY $\left.{ }^{27}, 1998\right)$, este teve um tratamento conceitual mais significativo no início do século passado e só na década de 60 veio a ter ampla aceitação nos EUA, como ferramenta de avaliação de investimentos.

De acordo com Akalu ${ }^{28}$ (2001 apud SHINODA, 2008, p.47), Franco Modigliani e Merton Miller fundamentaram as técnicas de avaliação de investimentos, baseadas no valor do dinheiro no tempo - como são conhecidas com a introdução do custo médio de capital.

A questão do valor do dinheiro no tempo se faz importante na análise de investimentos, pois sustenta a tomada de decisão - por parte dos administradores financeiros - em empreendimentos ou projetos.

\footnotetext{
${ }^{26}$ PARKER, R. H. Discounted cash flow in historical perspective. Journal of Accounting Research, V.6, n.1, Spring, 1968. p.58-71.

${ }^{27}$ LEFLEY, F. Accounting rate of return: back to basics. Management Accounting; mar.1998, 76.3.ABI/INFORM Global. p.52-53.

${ }^{28}$ AKALU, M.M. Re-examing project appraisal and control: developing a focus on wealth creation. International Project Management, n. 19, p. 375-383, 2001.
} 
Segundo Gitman (1997) de certa forma o valor do dinheiro no tempo é a linguagem das finanças, pois é um denominador comum para discutir transações e oportunidades financeiras. Conclui Gitman (1997 p. 150):

[...] O valor do dinheiro no tempo estabelece a ponte entre 0 consumo e o investimento $\mathrm{O}$ dinheiro pode ser convertido em produtos tangíveis e ser consumido agora, ou você pode investi-lo e adiar seu consumo. Você agora adia a compra de produtos porque espera que seu investimento no futuro tenha um valor maior ainda.

A tomada de decisão sobre investimentos pode ser baseada nos fluxos de caixa esperados em vários instantes no tempo. Esta decisão pode ser exercida quando considerados os valores sob dois pontos de vista: (i) o valor presente; e (ii) o valor futuro que quando aplicados corretamente podem resultar - sob perspectivas diferentes - nas mesmas decisões. Para facilitar o entendimento apresenta-se na figura 10 o conceito de capitalização e desconto, respectivamente utilizados nas técnicas de valor futuro e valor presente. As fórmulas apresentadas seguem a notação de Gitman (1997).

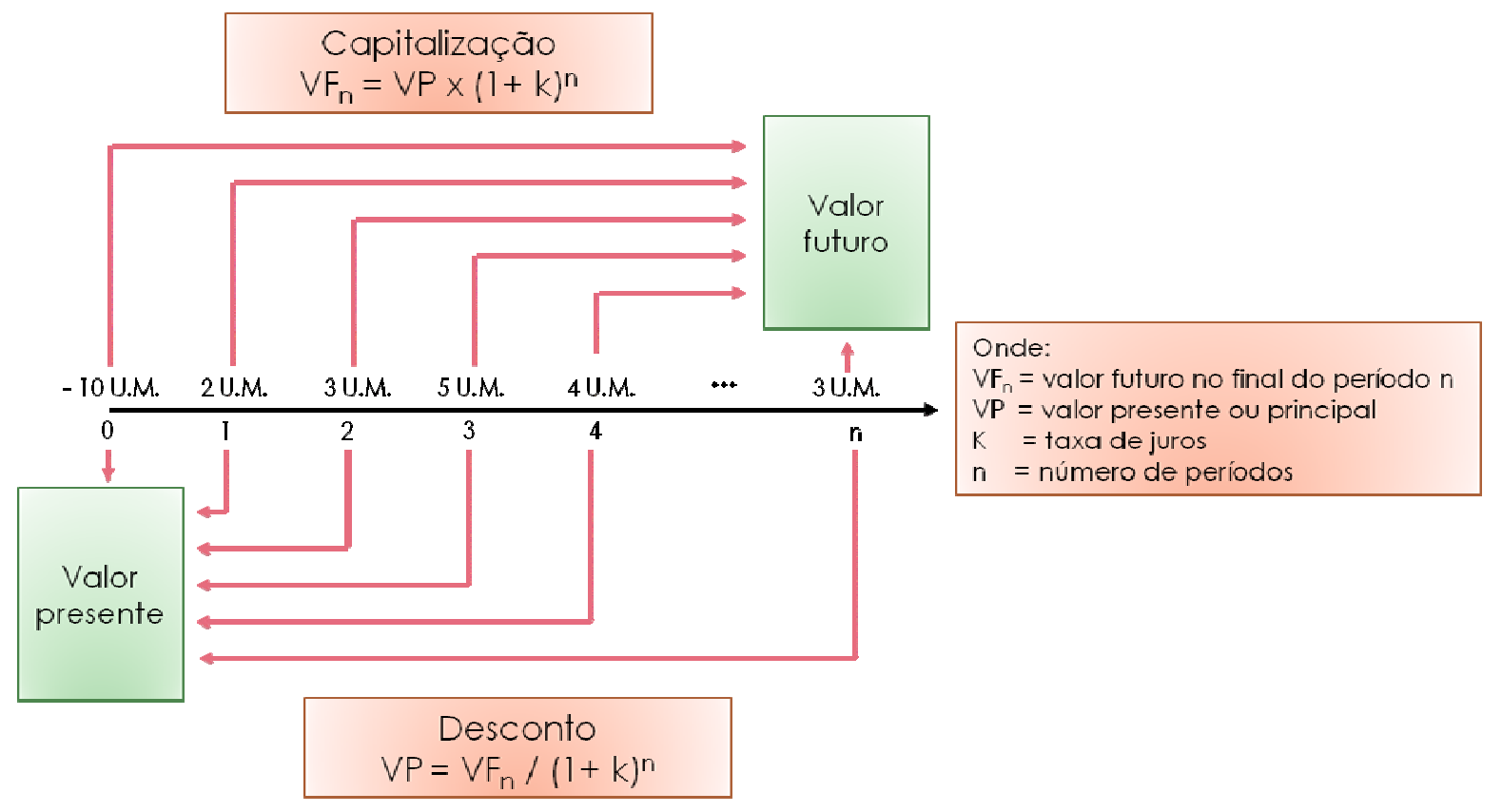

Figura 10 - Representação gráfica do conceito de capitalização e desconto

A técnica de valor futuro utiliza o valor do fluxo de caixa num determinado momento para capitalizar e apurar o valor futuro de cada fluxo de caixa no final da 
vida do investimento. Já a técnica do valor presente utiliza o mesmo conceito para descontar o valor de cada fluxo de caixa para o momento zero e, a partir da somatória dos fluxos encontra-se o valor presente do investimento.

De acordo com Gitman (1997) os administradores tendem a confiar principalmente, em técnicas de valor presente, uma vez que a decisão é tomada no tempo zero.

Entendido o conceito do valor do dinheiro no tempo passa-se a descrever as técnicas utilizadas nas análises econômicas. Para uma descrição sistemática das técnicas utilizadas na análise econômica - que se utilizam do método de fluxo de caixa - adotar-se-á a divisão destes em: (i) técnicas que não consideram o valor do dinheiro no tempo e (ii) técnicas que consideram o valor do dinheiro no tempo.

(i) Técnicas tradicionais que não consideram o valor do dinheiro no tempo

Segundo Balarine (2004) as técnicas tradicionais que desconsideram o valor do dinheiro no tempo são mais comumente utilizadas devido à simplicidade de aplicação. Destaca entre essas a Taxa de Retorno Contábil ${ }^{29}$ e o Payback Simples ${ }^{30}$

\section{- Taxa de Retorno Contábil (TRC)}

A TRC utiliza o lucro contábil para medir o benefício do projeto. É representada por uma porcentagem do lucro $(\mathrm{L})$ como função das receitas do projeto (R). É representada pela Equação ${ }^{31}$ (4):

$$
\operatorname{TRC}=\frac{L}{R}
$$

Onde:

TRC é a taxa de retorno contábil;

$\mathrm{L}$ é o lucro depois do imposto de renda; e

$\mathrm{R}$ é a receita.

\footnotetext{
${ }^{29}$ ARR - Accounting Rate Return.

${ }^{30}$ PBP - Payback Period.

${ }^{31}$ Notação utilizada por Balarine (2004)
} 
Do ponto de vista prático a TRC, fornece a quantidade de vezes que o lucro líquido cobre por ano o investimento total realizado (HIRSCHFELD, 1993).

\section{- Período de Payback Simples (PBS)}

Representa o número de períodos necessários para que a soma dos benefícios econômicos se iguale à soma dos dispêndios. Pode ser representado pela Equação (5):

$$
P R=T \text { quando } \sum_{t=0}^{T} F C_{t}=10
$$

Onde:

PR é o período de recuperação;

$\mathrm{FC}_{\mathrm{t}}$ é o fluxo de caixa total no período t; e

$\mathrm{I}_{\mathrm{o}}$ é o fluxo de caixa inicial do investimento.

Embora sejam classificados como um mecanismo útil na avaliação de alternativas de investimento, tanto a TRC quanto o PBS, são classificados como técnicas limitadas - tanto para a avaliação econômica de um investimento quanto para a o orçamento de capital de projetos - pois não leva em conta o valor do dinheiro no tempo o que pode conduzir a decisões equivocadas em relação ao investimento. Especificamente para o PBS as principais desvantagens atribuídas à utilização deste são: (i) não considerar o valor do dinheiro no tempo; e (ii) não considerar os fluxos de caixa após o período de recuperação. Porém existem algumas vantagens na sua utilização, a saber: (i) facilidade de cálculo e compreensão; (ii) fornecer uma ideia do grau de liquidez e de risco do projeto; (iii) ser utilizado como critério de desempate entre projetos mutuamente excludentes (BALARINE, 2004; BORDEAUX-REGO et al., 2006; GITMAN, 1997; SAMPAIO FILHO, 2008; SHINODA, 2008). 
(ii) Técnicas tradicionais que consideram o valor do dinheiro no tempo

\section{- Técnica do Payback Descontado}

A técnica do Payback Descontado é similar ao Payback Simples, porém considera uma taxa de atratividade ou de desconto. Desta forma, adicionando-se o custo de capital, considera-se o valor do dinheiro no tempo (BORDEAUX-RÊGO et al., 2006). A tabela 8 apresenta um exemplo:

Tabela 8 - Fluxo de caixa para cálculo do Payback Descontado de um projeto de seis anos

\begin{tabular}{lccccccc}
\hline \multicolumn{1}{c}{ Ano } & $\mathbf{0}$ & $\mathbf{1}$ & $\mathbf{2}$ & $\mathbf{3}$ & $\mathbf{4}$ & $\mathbf{5}$ & $\mathbf{6}$ \\
\hline Fluxos de caixa & -200.000 & 40.000 & 45.000 & 60.000 & 65.000 & 50.000 & 35.000 \\
Valor presente & -200.000 & 36.364 & 37.190 & 45.079 & 44.396 & 31.046 & 19.756 \\
Valor acumulado & -200.000 & -163.636 & -126.446 & -81.367 & -36.971 & -5.926 & 13.831 \\
\hline
\end{tabular}

Fonte: Adaptado de Bordeaux-Rego, (2006).

Taxa de desconto considerada: $10 \%$ aa.

Nota-se que a técnica se aproxima da técnica do Valor Presente Líquido (VPL). O valor acumulado no sexto ano, atualizado para a data 0 é o próprio VPL do projeto. Porém o método não leva em conta todos os fluxos de caixa e sim apenas o instante no tempo em que o saldo acumulado torna-se positivo.

\section{- Técnica do Valor Presente Líquido}

Segundo Akalu ${ }^{32}$ (2001, apud SHINODA, 2008, p. 49), embora a ocorrência do conceito de valor presente datar do ano de 1540, os fundamentos do dinheiro no tempo foram estabelecidos por Irving Fischer em 1930, onde o valor de um bem é determinado considerando-se o valor presente dos benefícios futuros que ele proporcionará, calculados por meio de uma taxa de desconto.

De acordo com Gitman (1997), por utilizar o valor do dinheiro no tempo, o Valor Presente Líquido é considerado uma técnica sofisticada de análise de orçamentos de capital. A técnica desconta os fluxos de caixa a uma taxa especificada. Essa taxa - frequentemente chamada de custo de capital, taxa de

${ }^{32}$ AKALU, M.M. Re-examing project appraisal and control: developing a focus on wealth creation. International Project Management, n. 19, p. 375-383, 2001. 
desconto ou custo de oportunidade - refere-se ao retorno mínimo que poderia ser obtido por um investimento ou projeto alternativo.

O Valor Presente Líquido (VPL) é obtido subtraindo-se o investimento inicial (II) do valor presente das entradas de caixa $\left(\mathrm{FC}_{\mathrm{t}}\right)$, descontadas a uma taxa igual ao custo de capital da empresa $(k)$, e mostrado pela Equação ${ }^{33} 6$ :

$$
V P L=F C o+\sum_{t=1}^{n} \frac{F C_{t}}{(1+k)^{t}}
$$

Onde:

VPL é o valor presente líquido;

$\mathrm{FC}_{0}$ é o fluxo de caixa total no tempo 0;

$\mathrm{FC}_{\mathrm{t}}$ é o fluxo de caixa total no período $\mathrm{t}$;

k é a taxa de desconto que iguala o VPL a zero, portanto, sendo a própria TIR; e $\mathrm{t}$ = é o número de períodos a que se refere o fluxo de caixa.

Com a utilização do VPL todas as entradas e saídas são traduzidas em valores monetários atuais. Em se tratando de investimentos convencionais, o investimento inicial deve ser expresso em termos de valores monetários atuais. Do contrario, o VPL de um projeto deverá ser obtido subtraindo-se o valor presente das saídas dos valores presente das entradas de caixa (GITMAN, 1997).

Em relação ao VPL, os autores concordam com o critério de decisão, no caso de aceitar/rejeitar o projeto. Quando VPL > 0, se aceita o projeto; quando VPL $=0$ é indiferente aceitar ou não e quando VPL $<0$ rejeita-se o projeto (BORDEAUXREGO et al., 2006; GITMAN, 1997; SHINODA 2008).

Em relação às desvantagens da utilização do VPL, Shinoda (2008) aponta duas críticas: (i) quanto a sua aplicação na comparação de projetos mutuamente excludentes, com investimentos iniciais diferentes e (ii) quanto a sua aplicação na comparação de projetos com duração diferentes. Ainda Meirelles (2004) sinaliza que quando os fluxos de caixa futuros são estimados, podem divergir do esperado o que consiste no principal problema com relação à técnica.

\footnotetext{
${ }^{33}$ Notação utilizada por Shinoda (2008).
} 


\section{- Técnica da Taxa Interna de Retorno}

Um projeto de investimento é considerado economicamente viável - em relação à Taxa Interna de Retorno (TIR) - se esta for superior ao custo de oportunidade do capital.

O conceito de taxa interna de retorno foi instituído por Keynes, conforme diz: "Eu defino a eficiência marginal do capital como sendo a taxa de desconto que tornaria o valor presente do fluxo de anuidades esperadas deste capital, durante toda a sua existência, exatamente igual ao seu preço de oferta" (KEYNES ${ }^{34} 1988$ apud SHINODA 2008, p.52).

Segundo Gitman (1997), a Taxa Interna de Retorno (TIR) é possivelmente a técnica sofisticada mais utilizada na análise de investimento. É definida como a taxa de desconto que iguala o valor presente das entradas de caixa ao investimento inicial. O autor define a TIR como a taxa de retorno que iguala o valor presente das entradas dos fluxos de caixa ao investimento inicial referente a um investimento ou projeto. Matematicamente a TIR é obtida resolvendo-se a Equação 2 para o valor de $k$ que torne o VPL igual a zero, conforme apresenta a Equação ${ }^{35} 7$ :

$$
0=F C O+\sum_{t=1}^{n} \frac{F C_{t}}{(1+k)^{2}}
$$

Onde:

$\mathrm{FC}_{0}$ é o fluxo de caixa total no tempo 0;

$\mathrm{FC}_{\mathrm{t}}$ é o fluxo de caixa total no período $\mathrm{t}$;

k é o valor da TIR que iguala o VPL a zero; e

$\mathrm{n}=$ é o número de períodos a que se refere o fluxo de caixa.

Gitman (1997) conclui que a TIR é utilizada para decisões "aceitar-rejeitar" o projeto e garante que a empresa obtenha, pelo menos, sua taxa requerida de retorno.

\footnotetext{
${ }^{34}$ KEYNES. J.M. A Teoria geral do juro, da moeda e do emprego. São Paulo: Abril Cultural, 1988. P.164

${ }^{35}$ Notação de Gitman (1997).
} 
De acordo com Meirelles (2004), a TIR é um parâmetro de rentabilidade do projeto. A TIR é calculada por meio dos fluxos de caixa futuros e sendo maior que a taxa mínima de retorno, em princípio, aceita-se o projeto; se menor, rejeita-se. Conclui que como os fluxos de caixa para o cálculo da TIR são estimados em previsões futuras, e essas passíveis de divergências em relação ao esperado, a técnica pode se tornar falha, sob este aspecto.

Barbieri et. al (2007), demonstram que TIR apresenta diversos pontos polêmicos. Argumenta:

[...] a TIR não representa uma medida correta do retorno do investimento. Somente nos casos onde ocorrem fluxos convencionais, que se caracterizam por um desembolso inicial e um recebimento final, a TIR representaria o retorno sobre o capital investido. Estes fluxos são típicos de certas aplicações financeiras, mas raros no âmbito dos projetos das áreas de produção e operações. Os fluxos de caixa intermediários, que ocorrem com muita freqüência em projetos dessas áreas, retiram da TIR a condição de medida de retorno sobre o investimento.

O autor atribui esse problema ao fato da TIR resultar da solução de uma equação polinomial, de grau " $n$ " que pode admitir até " $n$ " raízes reais positivas, sendo o seu número máximo igual ao numero de vezes em que ocorre troca de sinal dos coeficientes (CFj). Em outras palavras, o número máximo de raízes reais positivas será igual ao numero de vezes, em que a sequência do fluxo de caixa muda de sinal, durante a vida do projeto. Conclui na utilização parcimoniosa da TIR.

\subsection{Análises econômicas aplicadas na pecuária de corte}

Vários são os métodos de análise econômica que podem ser aplicados à área da zootecnia. Estes são aplicados de acordo com o objetivo, complexidade e horizonte temporal da análise que se pretende realizar.

Segundo Gameiro (2009), tem-se percebido - com maior frequência nos últimos dez anos - maior demanda de utilização de análises econômicas dos pesquisadores da área, em função das exigências das instituições de fomento na liberação de recursos. Considera também que a prática foi facilitada após o ano de 
1994, quando os preços se estabilizaram no país e desta forma a análise econômica tornou-se mais confiável em relação a possíveis variações dos preços nominais dos recursos alocados.

Gameiro (2009) propõe uma organização didática dos métodos, visto que estes podem ser complementares, conforme apresenta a figura 11.

Descreve os principais métodos: (i) Margem bruta: Obtida subtraindo-se os custos variáveis das receitas totais; (ii) Lucro: Obtido subtraindo-se das receitas totais os custos fixos e também os custos variáveis (iii) Análise de investimentos: Realizada inserindo-se no contexto o horizonte temporal da análise, pois incorpora o efeito financeiro (valor do dinheiro no tempo) na análise econômica. As técnicas mais comuns e utilizadas nesta análise de investimentos são: (i) Payback Descontado; (ii) Valor Presente Líquido (VPL) e (iii) Taxa Interna de Retorno (TIR).



Fonte: Adaptado de Gameiro (2009).

Figura 11 - Representação sistemática dos principais métodos de análise econômica aplicados a processos produtivos

Ainda Gameiro (2009) sugere que os três métodos podem ou não incorporar o risco em sua elaboração, o que resulta em dois outros tipos de análise: (i) Determinística: Admite-se que não existe risco ou incerteza. Desta forma todos os parâmetros são perfeitamente conhecidos e não sofrem alterações no horizonte de tempo de análise. (ii) Estocástica: Relaxa-se a hipótese da fixação dos parâmetros que compõe a análise. Admitem-se distribuições de probabilidades de ocorrências. 
Finaliza que as avaliações podem evoluir para modelos mais complexos denominados genericamente como modelos bioeconômicos - onde se estabelecem relações de causa e efeito entre as variáveis econômicas e biológicas. Da evolução surgem modelos positivistas ou normativos, a saber: (i) modelo de simulação e (ii) modelo de otimização, respectivamente.

A utilização das técnicas de análise de investimento torna-se importante para a avaliação de empreendimentos em pecuária de corte, a partir do momento que esta atividade - por suas características e peculiaridades - pode compreender um período relativamente longo. Desta forma deve-se considerar o efeito do tempo nos processos produtivos e na utilização dos recursos.

De acordo com os critérios utilizados nas análises de investimento, os seguintes trabalhos podem ser referenciados para a utilização na pecuária de corte:

Abreu et al. (2003) analisaram quatro efeitos decorrentes da implantação de período de monta (PM) no sistema de produção de bovinos de corte na fase de cria. Utilizaram na avaliação o orçamento parcial de custos, sem a inclusão de juros sobre o capital imobilizado e circulante, e pró-labore de administração. Nesse sentido, foram considerados os seguintes itens na composição dos custos: vacina contra febre; vacina contra carbúnculo sintomático; vacina contra brucelose; vermifugação dos animais até dois anos, três vezes ao ano; suplemento mineral; mão de obra; encargos sociais; reparo e manutenção de benfeitorias (casas, curral e cercas); depreciações de benfeitorias, veículo e cavalos (considerou-se $50 \%$ do valor inicial); despesas com veículo; imposto sobre a terra; contribuição social; e touros de reposição. Para a análise foi utilizado um período de 6 anos e foi realizada por meio das técnicas: (i) Valor Presente Líquido (VPL); (ii) Relação Benefício/Custo (B/C); e (iii) Taxa Interna de Retorno (TIR). Utilizaram-se também cinco cenários para a adoção das tecnologias de PM.

Maya (2003), com o intuito de comparar os resultados produtivos e econômicos de pastagens adubadas intensivamente com ou sem o uso de irrigação, avaliando o desempenho animal, taxa de lotação e produtividade. A avaliação econômica foi efetuada com a determinação: (i) do Lucro líquido (LL), (ii) da Taxa de retorno sobre o ativo (TRA) e (iii) da Taxa Interna de Retorno (TIR), por meio de simulações determinísticas e estocásticas.

Peres et al. (2004) analisaram a viabilidade econômica para três diferentes modalidades de suplementação para a recria de fêmeas de novilhas leiteiras 
mestiças Holandês-Zebu em pastagens de capim-elefante na região Norte Fluminense. Foram considerados os custos implícitos e explícitos, bem como os gastos incorridos na infraestrutura do sistema de produção. O horizonte temporal da análise foi de 12 anos e foi realizada a por meio da utilização de dois indicadores econômicos: (i) Valor Presente Líquido (VPL) e (ii) Taxa Interna de Retorno (TIR). O trabalho contemplou uma análise de sensibilidade do sistema para cada item individualmente e com variação de 1\% - do fluxo de caixa, com o objetivo de avaliar a participação individual de cada componente do fluxo de caixa sobre os indicadores econômicos utilizados. Para estudar o risco que cada sistema poderia apresentar diante das oscilações de preços no mercado, utilizou-se a Simulação de Monte Carlo.

Coan et al. (2008) conduziram um experimento com o objetivo de avaliar o desempenho, as características de carcaça e a viabilidade econômica do confinamento de bovinos alimentados com silagem dos capins tanzânia ou marandu, com 0 e 10\% de polpa cítrica peletizada (PCP), em comparação à silagem de milho. De acordo com o autor, a composição do fluxo de caixa envolveu os custos de alimentação, aquisição de animais, e outros (mão de obra, produtos veterinários, combustível e outros) e o juro sobre o capital. Ainda considerou na metodologia para o cálculo do custo das rações - a depreciação na ordem de 15\% em relação às instalações, maquinários, à mão de obra, medicamentos, entre outros. O período da análise foi de 80 dias e realizada por meio da Taxa Interna de Retorno (TIR).

Marques e Perina (2004) comparam a rentabilidade das principais atividades agrícolas na região Noroeste do Estado de São Paulo, a saber: (i) a pecuária de corte, (ii) o cultivo de laranja e (iv) o cultivo da cana-de-açúcar. Para a elaboração dos fluxos de caixa utilizaram um horizonte projetado de 20 anos e ao final destes, os valores da terra e do rebanho foram acrescidos como valor residual nas receitas apuradas.

Porém são escassos os trabalhos que tratam do assunto de forma interativa e com a utilização das técnicas de análise de investimento, como se propõem este trabalho. 


\section{MATERIAL E MÉTODOS}

A avaliação econômica do empreendimento resultou do conjunto de informações: dos recursos necessários para a sua execução, das tecnologias a serem aplicadas na produção e obtenção dos produtos, e das receitas monetárias.

As descrições dos objetivos ${ }^{36}$, da infraestrutura do empreendimento ${ }^{37}$, das características e tecnologias utilizadas no planejamento da produção e os memoriais de cálculos utilizados na construção dos fluxos de caixa, dentre outros foram elaboradas como apêndices ${ }^{38}$. Essas informações são imprescindíveis para a construção dos fluxos de caixa.

A análise foi realizada por meio dos fluxos de caixa estimados para o empreendimento, que foram obtidos de forma direta, ou seja, rastreando-se as entradas e saídas de caixa previstas de disponibilidades (SOUZA, 2003). Os fluxos de caixa foram construídos para os anos calendários de 2009 até 2038, sendo o primeiro ano denominado ano 1 e o último ano 30 do projeto.

As entradas de caixa decorreram de duas situações, a saber: (i) receitas brutas anuais resultantes da comercialização dos animais e (ii) entradas de caixa decorrentes de operação de crédito rural, com recursos do BNDES.

(i) Receitas brutas anuais resultantes da comercialização dos animais

Em termos de comercialização definiu-se a venda e o abate da produção em plantas frigoríficas devidamente inscritas no Serviço de Inspeção Federal ${ }^{39}$ (SIF) para o estado de São Paulo ${ }^{40}$ e inscritas na Associação Brasileira das Indústrias Exportadoras de Carnes (ABIEC, 2010).

\footnotetext{
${ }^{36}$ Apêndice $\mathrm{A}$.

37 Apêndice $B$.

38 Todos os apêndices citados, na versão impressa da dissertação, encontram-se em formato digital (CD).

39 Órgão do Ministério da Agricultura, Pecuária e Abastecimento do Brasil.

${ }^{40}$ As plantas associadas para o Estado de São Paulo localizam-se nos municípios de: São Paulo, Lins, Barretos, José Bonifácio, Santa Fé do Sul, Cajamar, Presidente Venceslau, Louveira, Santos, Olímpia, Carapicuíba, Santana do Parnaíba, Bauru, Barueri, Promissão, Guaiçara, Araçatuba, Lençóis Paulista, Campinas (ABIEC, 2010).
} 
A receita bruta foi obtida da multiplicação do número de animais disponíveis para a comercialização pelo valor monetário estipulado por categoria de animais. A previsão de saída de animais - destinados à comercialização - do sistema está representada na tabela 9 e detalhada no apêndice C. Nota-se que a tabela foi apresentada até o ano de 2017, sendo este o ano no qual ocorreu a estabilização do rebanho e da produção, que se manteve constante até o ano de 2038.

Tabela 9 - Projeção de comercialização de animais por sexo e categoria animal - 20102017

\begin{tabular}{|c|c|c|c|c|c|c|c|c|c|}
\hline \multirow[b]{2}{*}{ Rebanho } & & \multicolumn{8}{|c|}{ Ano } \\
\hline & & 2010 & 2011 & 2012 & 2013 & 2014 & 2015 & 2016 & 2017 \\
\hline \multirow[t]{4}{*}{ Fêmeas } & $>36$ meses & - & $10^{1}$ & $11^{2}$ & $26^{3}$ & $12^{5}$ & $13^{8}$ & $13^{11}$ & $13^{14}$ \\
\hline & $\begin{array}{c}24 \text { a } 36 \\
\text { meses }\end{array}$ & - & - & - & 0 & $2^{6}$ & $1^{9}$ & $1^{12}$ & $1^{15}$ \\
\hline & $\begin{array}{c}12 \text { a } 24 \\
\text { meses }\end{array}$ & - & - & - & $23^{4}$ & $35^{7}$ & $39^{10}$ & $35^{13}$ & $35^{16}$ \\
\hline & 0 a 12 meses & - & - & - & - & - & - & - & - \\
\hline \multirow[t]{4}{*}{ Machos } & $>36$ meses & - & - & - & - & - & - & - & - \\
\hline & $\begin{array}{c}24 \text { a } 36 \\
\text { meses }\end{array}$ & - & - & - & - & - & - & - & - \\
\hline & $\begin{array}{c}12 \text { a } 24 \\
\text { meses }\end{array}$ & - & - & - & - & - & - & - & - \\
\hline & 0 a 12 meses & - & - & 44 & 49 & 54 & 49 & 49 & 49 \\
\hline
\end{tabular}

${ }^{1} 10$ Fêmeas não prenhes. ${ }^{2} 11$ Fêmeas não prenhes. ${ }^{3} 10$ Fêmeas não prenhes e 16 fêmeas com prenhezes diagnosticas. ${ }^{4} 4$ Fêmeas não prenhes e 19 fêmeas com prenhezes diagnosticas. ${ }^{5} 12$ Fêmeas não prenhes. ${ }^{6} 2$ Fêmeas não prenhes. ${ }^{7} 5$ Fêmeas não prenhes e 30 fêmeas com prenhezes diagnosticas. ${ }^{8} 13$ Fêmeas não prenhes. ${ }^{9} 1$ Fêmea não prenhe. ${ }^{10} 5$ Fêmeas não prenhes e 34 fêmeas com prenhezes diagnosticas. ${ }^{11} 13$ Fêmeas não prenhes. ${ }^{12} 1$ Fêmea não prenhe. ${ }^{13} 5$ Fêmeas não prenhes e 30 fêmeas com prenhezes diagnosticas. ${ }^{14} 13$ Fêmeas não prenhes. ${ }^{15} 1$ Fêmea não prenhe. ${ }^{16} 5$ Fêmeas não prenhes e 30 fêmeas com prenhezes diagnosticas.

As projeções para as entradas de caixa - resultantes da comercialização dos animais - foram efetuadas contra entrega dos produtos e livres de impostos, encargos e fretes, sendo estes itens de responsabilidade do comprador.

Com relação aos preços dos animais comercializados utilizaram-se como referência os preços diários, a vista, pagos aos produtores - por arroba de carne $e^{41}$ - para o estado de São Paulo, fornecida pelo Centro de Estudos Avançados em Economia Aplicada (CEPEA). O período de coleta dos dados foi de 01 de janeiro de 2000 até o dia 28 de julho de 2010 (CEPEA, 2010). As médias mensais dos preços nominais diários foram obtidas para todos os meses do período analisado. Após deflacionou-se as médias nominais mensais de forma a atualizá-las para

\footnotetext{
${ }^{41}$ Peso da carcaça do animal abatido.
} 
valores reais equivalentes a julho de 2010, conforme metodologia tradicional apresentada por Viana et al. (2009) e com a utilização da fórmula (15):

Onde:

$P R t=$ Preço Real no mês "t";

$P N t=$ Preço Nominal corrigido no mês "t";

$I P a=I G P-D I$ de julho de 2010; e

$I P t=I G P-D I$ no mês "t".

Para o deflacionamento dos preços utilizou-se o Índice Geral de Preços $\left(I G P-D I^{42}\right.$ ), calculado pela Fundação Getúlio Vargas (FGV, 2010). Os valores numéricos, índices e tabelas geradas para o cálculo estão localizados no apêndice D.

Para a simulação das variações das receitas nos fluxos de caixa utilizouse as médias - mínima, geral e máxima - anuais corrigida, conforme apresentado no gráfico 1.

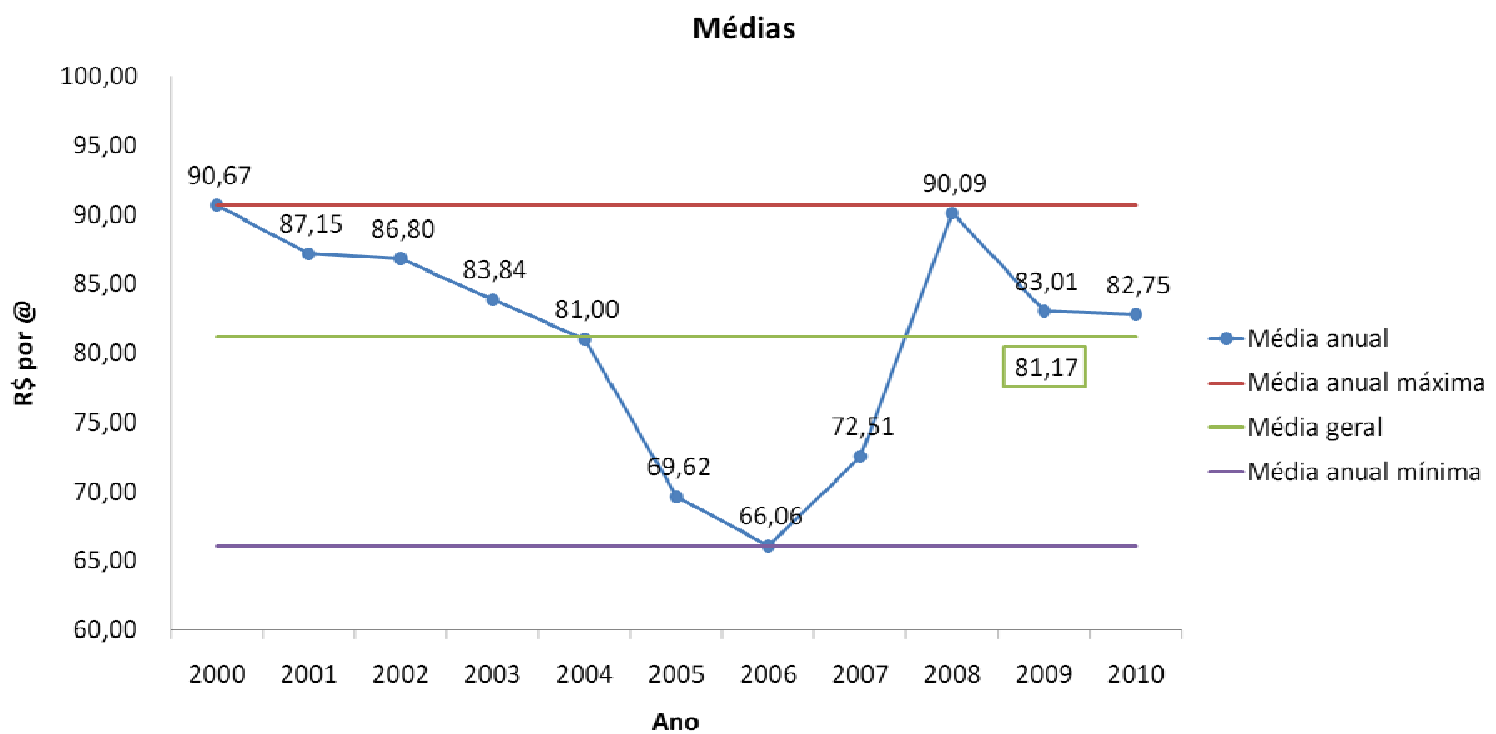

Gráfico 1 - Médias anuais dos preços corrigidos - 2000-2010

\footnotetext{
${ }^{42} \mathrm{O}$ Índice Geral de Preços - Disponibilidade Interna é um índice econômico para correção de preços e valores. Mede o comportamento dos preços pesquisados do dia 1 ao último dia do mês corrente. É formado por três taxas: Índice de Preços por Atacado (IPA) - que corresponde a 60\% do IGP-DI; Índice de Preços ao Consumidor (IPC) - que responde por 40\% do IGP-DI total; e o Índice Nacional de Custo da Construção (INCC) - que é 10\% do IGP-DI.
} 
Os valores das médias encontrados foram: média anual mínima de R $\$$ 66,06/@; média geral R\$ 81,17/@ e média anual máxima R\$ 90,09/@. Neste trabalho são denominadas: nível mínimo, nível médio e nível máximo, respectivamente.

Os critérios para estabelecimento dos valores de venda por categoria animal foram: Fêmeas não prenhes, com mais de 36 meses de idade, peso bruto de $450 \mathrm{~kg}$, com 53\% de aproveitamento de carcaça, pagamento de 100\% do preço da arroba de carne para a categoria fêmea; Fêmeas não prenhes, de 24 a 36 meses de idade, peso bruto de $410 \mathrm{~kg}$, com 53\% de aproveitamento de carcaça, pagamento de $100 \%$ do preço da arroba de carne para a categoria fêmea; Fêmeas não prenhes, de 12 a 24 meses de idade, peso bruto de 360 kg, com 53\% de aproveitamento de carcaça, pagamento de $100 \%$ do preço da arroba de carne para a categoria fêmea; Fêmeas prenhes, com mais de 36 meses de idade, peso bruto de $450 \mathrm{~kg}$, pagamento de 100\% do preço da arroba de carne para a categoria fêmea, com ágio de 3 arrobas de carne para a categoria macho; Fêmeas prenhes, de 12 a 24 meses de idade, peso bruto de 360 kg, pagamento de $100 \%$ do preço da arroba de carne para a categoria macho, com ágio de 3 arrobas de carne para a categoria macho; Machos de 0 a 12 meses de idade, peso bruto de $210 \mathrm{~kg}$, pagamento de $100 \%$ do preço da arroba de carne para a categoria macho, com ágio de $25 \%$ no preço da arroba de carne para a categoria macho; Machos de 12 a 24 meses de idade, peso bruto de 460 kg, com 53\% de aproveitamento de carcaça, pagamento de $100 \%$ do preço da arroba de carne para a categoria macho.

(ii) Entrada de caixa decorrente de operação de crédito rural.

A projeção dos fluxos de caixa com a utilização de capital de terceiros foi realizada por meio de simulação de operação de crédito rural. Os parâmetros utilizados foram os fornecidos com base nos programas agropecuários do governo federal administrados pelo BNDES, via instituições conveniadas (BNDES, 2010).

Para efeito de lançamento nos fluxos de caixa, foram definidas duas situações derivadas de empréstimo para pessoa física, no limite estabelecido pelo 
programa denominado PRODUSA ${ }^{43}$ : pagamento dos juros incorporados ao valor inicial da dívida após o período de carência e pagamento dos juros devidos no período de carência. As tabelas 10 e 11 ilustram as duas situações, respectivamente apresentadas:

Tabela 10 - Saldo devedor, prestação, juros e amortizações decorrentes de operação de crédito rural com pagamento dos juros incorporados ao valor inicial da dívida após o período de carência

\begin{tabular}{cccccc}
\hline Ano $(\mathrm{n})^{1}$ & Ano $^{2}$ & Saldo devedor $^{3}$ & Prestação & Juros $^{4}$ & Amortização $^{5}$ \\
\hline 1 & 2009 & - & - & - & - \\
2 & 2010 & $300.000,00$ & - & - & - \\
3 & 2011 & $320.250,00$ & - & - & - \\
4 & 2012 & $341.866,88$ & - & - & - \\
5 & 2013 & $364.942,89$ & - & - & - \\
6 & 2014 & $329.051,15$ & $60.525,38$ & $24.633,65$ & $35.891,73$ \\
7 & 2015 & $290.736,73$ & $60.525,38$ & $22.210,95$ & $38.314,43$ \\
8 & 2016 & $249.836,08$ & $60.525,38$ & $19.624,73$ & $40.900,65$ \\
9 & 2017 & $206.174,63$ & $60.525,38$ & $16.863,94$ & $43.661,44$ \\
10 & 2018 & $159.566,04$ & $60.525,38$ & $13.916,79$ & $46.608,59$ \\
11 & 2019 & $109.811,37$ & $60.525,38$ & $10.770,71$ & $49.754,67$ \\
12 & 2020 & $56.698,25$ & $60.525,38$ & $7.412,27$ & $53.113,11$ \\
13 & 2021 & 0,00 & $60.525,38$ & $3.827,13$ & $56.698,25$ \\
\hline
\end{tabular}

Nota: $i=6,75 \%$ ao ano.

${ }^{1}$ Ano do projeto. ${ }^{2}$ Ano calendário. ${ }^{3} \mathrm{SD}_{n}=\mathrm{SD}_{\mathrm{n}-1}-\mathrm{A}_{n} \cdot{ }^{4} \mathrm{~J}_{\mathrm{n}}=\mathrm{SD}_{\mathrm{n}-1} \times \mathrm{i}^{5}{ }^{5} \mathrm{~A}_{\mathrm{n}}=\mathrm{PMT}_{\mathrm{n}}-\mathrm{J}_{\mathrm{n}}$.

Tabela 11 - Saldo devedor, prestação, juros e amortizações decorrentes de operação de crédito rural com pagamento dos juros devidos no período de carência

\begin{tabular}{cccccc}
\hline Ano $(\mathrm{n})^{1}$ & Ano $^{2}$ & Saldo devedor $^{3}$ & Prestação & Juros $^{4}$ & Amortização $^{5}$ \\
\hline 1 & 2009 & - & - & - & - \\
2 & 2010 & $300.000,00$ & - & - & - \\
3 & 2011 & $300.000,00$ & $20.250,00$ & $20.250,00$ & - \\
4 & 2012 & $300.000,00$ & $20.250,00$ & $20.250,00$ & - \\
5 & 2013 & $300.000,00$ & $20.250,00$ & $20.250,00$ & - \\
6 & 2014 & $270.495,33$ & $49.754,67$ & $20.250,00$ & $29.504,67$ \\
7 & 2015 & $238.999,09$ & $49.754,67$ & $18.258,43$ & $31.496,24$ \\
8 & 2016 & $205.376,86$ & $49.754,67$ & $16.132,44$ & $33.622,23$ \\
9 & 2017 & $169.485,13$ & $49.754,67$ & $13.862,94$ & $35.891,73$ \\
10 & 2018 & $131.170,71$ & $49.754,67$ & $11.440,25$ & $38.314,42$ \\
11 & 2019 & $90.270,06$ & $49.754,67$ & $8.854,02$ & $40.900,65$ \\
12 & 2020 & $46.608,62$ & $49.754,67$ & $6.093,23$ & $43.661,44$ \\
13 & 2021 & 0,00 & $49.754,67$ & $3.146,08$ & $46.608,59$ \\
\hline
\end{tabular}

Nota: $i=6,75 \%$ ao ano.

${ }^{1}$ Ano do projeto. ${ }^{2}$ Ano calendário. ${ }^{3} \mathrm{SD}_{n}=\mathrm{SD}_{\mathrm{n}-1}-\mathrm{A}_{n} .{ }^{4} \mathrm{~J}_{\mathrm{n}}=\mathrm{SD}_{\mathrm{n}-1} \times \mathrm{i}^{5}{ }^{5} \mathrm{~A}_{\mathrm{n}}=\mathrm{PMT}_{\mathrm{n}}-\mathrm{J}_{n}$.

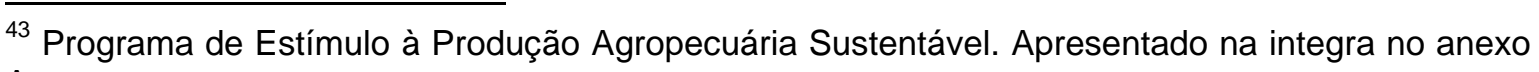
A 
Torna-se importante esclarecer que as instituições financeiras conveniadas têm cada qual sua política e aspectos normativos específicos para a concessão do crédito. Deste modo, as bases e critérios próprios das instituições conveniadas - como prazos, garantias, limites dentre outras exigências - são somados às restrições e aplicações dos Programas do Governo Federal. Portanto a existência dos programas de financiamento governamental não garante 0 acesso aos mesmos, com elaborados na íntegra.

As saídas de caixa foram projetadas a partir: dos investimentos iniciais decorrentes da implantação da infraestrutura (Apêndice E), dos gastos com a manutenção e reforma da lavoura de cana de açúcar (Apêndice F), dos gastos com a manutenção das pastagens (Apêndice $G$ ), dos gastos com o manejo do rebanho nos seus vários aspectos (Apêndice $H$ ).

Obtiveram-se nove possíveis combinações para a análise, a partir dos preços nominais corrigidos nos períodos determinados e das opções de investimento com recursos próprios e de terceiros. Essas combinações denominaram-se cenários, apresentados nos resultados de 1 a 9, conforme tabela 12:

Tabela 12 - Cenários para a determinação da viabilidade econômica do empreendimento obtidos a partir das definições das fontes de recursos monetários, modalidade de pagamento das prestações decorrentes de financiamento de terceiros e preços de venda dos produtos auferidos com base nas médias corrigidas dos preços, da arroba de carne

Fonte de recursos

\begin{tabular}{lccc}
\cline { 2 - 4 } Níveis de preços & Próprios & Próprios e CR1 & Próprios e CR2 $^{2}$ \\
\hline Mínimo $^{3}$ & Cenário 1 & Cenário 2 & Cenário 3 \\
Médio $^{4}$ & Cenário 4 & Cenário 5 & Cenário 6 \\
Máxima $^{5}$ & Cenário 7 & Cenário 8 & Cenário 9
\end{tabular}

${ }^{1}$ Saldo devedor, prestação, juros e amortizações decorrentes de operação de crédito rural com pagamento dos juros incorporados ao valor inicial da dívida após o período de carência; ${ }^{2}$ Saldo devedor, prestação, juros e amortizações decorrentes de operação de crédito rural com pagamento dos juros devidos no período de carência. ${ }^{3}$ Nível mínimo: $\mathrm{R} \$$ 66,06/@; ${ }^{4}$ Nível médio: R\$81,17/@; ${ }^{5}$ Nível máximo: R\$90,67/@.

Incluiu-se o cenário adicional (10) pelo fato de que um dos principais motivadores - se não o principal - da utilização do sistema sob alta lotação na pecuária comercial é a possibilidade do uso intensivo da terra, ao permitir a produção de um determinado número de animais em uma área reduzida. Neste 
cenário considerou-se a taxa de lotação máxima de 132 UA/ha para estabilização do rebanho sob pastejo no sistema de produção (Apêndice C). Admitindo 1,22 UA/ha como a taxa de lotação máxima (média de lotação animal para os meses de verão e de inverno) do sistema sob pastejo para a pecuária tradicional conforme Paniago (2002) - seriam necessários 108,20 ha para o desenvolvimento da atividade na situação dita "extensiva". Como a área total na qual foi planejado o sistema sob alta lotação foi de 23,67 ha, a opção pela implantação do sistema possibilitaria a liberação de 84,53 ha de terra. Especificamente para a região onde o sistema foi planejado, o arrendamento da terra para o cultivo da cana de açúcar por parte das usinas sucroalcooleiras apresentou-se como oportunidade para utilização da terra. A opção pelo arrendamento da área gerou uma renda ${ }^{44}$ anual no horizonte de tempo da análise e considerada a partir da entrega da terra para o arrendatário, a partir do ano de 2010.

As técnicas de análise utilizadas foram: Payback Simples, Payback Descontado, VPL e TIR. A Taxa Mínima de Atratividade (TMA) foi a SELIC ${ }^{45}$ META para o ano calendário de 2010, ou seja, 10,75\% ao ano.

Os cálculos foram realizados com a utilização de planilha eletrônica denominada Microsoft ${ }^{\circledR}$ Office Excel ${ }^{\circledR}$. Para a obtenção da TIR, quando da ocorrência de fluxos de caixa não convencionais utilizou-se a metodologia proposta por Lin $^{46}$ (1976 apud BARBIERI, 2007, p 137). A metodologia propõe que os fluxos de caixa intermediários positivos sejam levados para a data final do projeto e os fluxos de caixa negativos para a data inicial do mesmo. Combinandose esses procedimentos tem-se um fluxo de caixa de apenas dois pontos. Esse novo parâmetro do fluxo de caixa do projeto e associado a uma taxa de mercado de reinvestimento "ir" e a uma taxa, também de mercado de financiamento "if" foi denominado Taxa Interna de Retorno Modificada (TIRM).

\footnotetext{
${ }^{44}$ A renda anual baseou-se no pagamento de 20,66 toneladas de cana por hectare de terra arrendada. O preço definido para o pagamento da tonelada de cana foi de $\mathrm{R} \$ 50,00$ por tonelada. Estes parâmetros foram obtidos por meio de entrevistas às usinas sucroalcooleiras localizadas no município de Pirassununga. Refere-se à safra 2009/2010.

${ }^{45}$ É a taxa básica utilizada como referência pela política monetária. Divulgada pelo Comitê de Política Monetária (COPOM), tem vital importância na economia, pois as taxas de juros cobradas pelo mercado são balizadas pela mesma. É a taxa básica utilizada como referência pela política monetária.

${ }^{46}$ LIN, S. A. The modified internal rate of return and investment criterion. The Engineering
} Economist,v..21, Summer, pp. 237-247, 1976. 
A tabela 13 apresenta os resultados obtidos para o cenário 1, onde Payback Simples - representado pelo fluxo de caixa acumulado não descontado - ocorreu no $18^{\circ}$ ano do projeto. Considerando-se o valor do dinheiro no tempo, obteve-se que o Payback Descontado não ocorreu no prazo de análise. O VPL do investimento obtido foi de $\mathrm{R} \$ 243.839,89$ negativos no final do período. Observase que o investimento inicial considerado ${ }^{47}$ para o calculo do VPL foi obtido a partir dos fluxos de caixas líquidos ocorridos para os anos 1, 2 e 3, descontados e acumulados para o $3^{\circ}$ ano do projeto. A TIR obtida foi de 4,74\% ao ano.

Tabela 13 - Projeção do fluxo de caixa do empreendimento com utilização de recursos próprios e receita bruta auferida a partir da venda de animais com a utilização da média mínima dos preços corrigidos - 2009-2038

\begin{tabular}{ccccccccc}
\multicolumn{6}{c}{ continua } \\
\hline $\mathrm{AP}^{1}$ & $\mathrm{AC}^{2}$ & $\mathrm{ESC}^{3}$ & $\mathrm{RB}^{4}$ & $\mathrm{D}^{5}$ & $\mathrm{FCL}^{6}$ & $\mathrm{FCL}(\mathrm{AND})$ & $\mathrm{FCL}\left(\mathrm{D}^{8}\right)$ & $\mathrm{FCL}\left(\mathrm{AD}^{9}\right)$ \\
\hline 1 & 2009 & - & - & $-12.435,99$ & $-12.435,99$ & $-12.435,99$ & $-15.253,44$ & $-15.253,44$ \\
2 & 2010 & - & - & $-314.498,39$ & $-285.662,39$ & $-298.098,37$ & $-316.371,09$ & $-331.624,53$ \\
3 & 2011 & - & $9.768,29$ & $-213.900,92$ & $-198.077,07$ & $-496.175,44$ & $-198.077,07$ & $-529.701,60$ \\
4 & 2012 & - & $58.075,70$ & $-56.084,89$ & $1.990,81$ & $-494.184,63$ & $1.797,57$ & $-527.904,03$ \\
5 & 2013 & - & $95.679,00$ & $-56.992,58$ & $38.686,42$ & $-455.498,21$ & $31.540,68$ & $-496.363,34$ \\
6 & 2014 & - & $98.922,83$ & $-59.956,30$ & $38.966,53$ & $-416.531,68$ & $28.685,37$ & $-467.677,97$ \\
7 & 2015 & - & $98.344,06$ & $-57.044,76$ & $41.299,30$ & $-375.232,37$ & $27.451,61$ & $-440.226,36$ \\
8 & 2016 & - & $94.092,24$ & $-57.493,19$ & $36.599,05$ & $-338.633,33$ & $21.966,01$ & $-418.260,35$ \\
9 & 2017 & - & $94.261,86$ & $-68.292,85$ & $25.969,01$ & $-312.664,32$ & $14.073,20$ & $-404.187,15$ \\
10 & 2018 & - & $94.261,86$ & $-57.698,79$ & $36.563,07$ & $-276.101,25$ & $17.891,08$ & $-386.296,07$ \\
11 & 2019 & - & $94.261,86$ & $-57.045,19$ & $37.216,67$ & $-238.884,58$ & $16.443,25$ & $-369.852,83$ \\
12 & 2020 & - & $94.261,86$ & $-57.698,79$ & $36.563,07$ & $-202.321,52$ & $14.586,43$ & $-355.266,40$ \\
13 & 2021 & - & $94.261,86$ & $-57.045,19$ & $37.216,67$ & $-165.104,85$ & $13.406,03$ & $-341.860,37$ \\
14 & 2022 & - & $94.261,86$ & $-57.495,81$ & $36.766,05$ & $-128.338,80$ & $11.958,20$ & $-329.902,17$ \\
15 & 2023 & - & $94.261,86$ & $-57.045,19$ & $37.216,67$ & $-91.122,13$ & $10.929,81$ & $-318.972,35$ \\
16 & 2024 & - & $94.261,86$ & $-57.698,79$ & $36.563,07$ & $-54.559,07$ & $9.695,59$ & $-309.276,77$ \\
17 & 2025 & - & $94.261,86$ & $-68.292,85$ & $25.969,01$ & $-28.590,06$ & $6.217,89$ & $-303.058,88$ \\
18 & 2026 & - & $94.261,86$ & $-57.698,79$ & $36.563,07$ & $7.973,01$ & $7.904,72$ & $-295.154,16$ \\
19 & 2027 & - & $94.261,86$ & $-57.045,19$ & $37.216,67$ & $45.189,68$ & $7.265,04$ & $-287.889,12$ \\
20 & 2028 & - & $94.261,86$ & $-57.495,81$ & $36.766,05$ & $81.955,72$ & $6.480,42$ & $-281.408,70$ \\
21 & 2029 & - & $94.261,86$ & $-57.045,19$ & $37.216,67$ & $119.172,39$ & $5.923,12$ & $-275.485,58$ \\
22 & 2030 & - & $94.261,86$ & $-57.698,79$ & $36.563,07$ & $155.735,46$ & $5.254,26$ & $-270.231,32$ \\
\hline
\end{tabular}

${ }^{47}$ Utilizou-se esse procedimento na apuração dos valores em todos os cenários propostos. 
conclusão

\begin{tabular}{lllllllll}
\hline \hline 23 & 2031 & - & $94.261,86$ & $-57.045,19$ & $37.216,67$ & $192.952,13$ & $4.829,06$ & $-265.402,26$ \\
24 & 2032 & - & $94.261,86$ & $-57.495,81$ & $36.766,05$ & $229.718,18$ & $4.307,53$ & $-261.094,72$ \\
25 & 2033 & - & $94.261,86$ & $-68.292,85$ & $25.969,01$ & $255.687,18$ & $2.747,22$ & $-258.347,51$ \\
26 & 2034 & - & $94.261,86$ & $-57.495,81$ & $36.766,05$ & $292.453,23$ & $3.511,89$ & $-254.835,62$ \\
27 & 2035 & - & $94.261,86$ & $-57.045,19$ & $37.216,67$ & $329.669,90$ & $3.209,87$ & $-251.625,74$ \\
28 & 2036 & - & $94.261,86$ & $-57.698,79$ & $36.563,07$ & $366.232,96$ & $2.847,41$ & $-248.778,34$ \\
29 & 2037 & - & $94.261,86$ & $-57.045,19$ & $37.216,67$ & $403.449,63$ & $2.616,98$ & $-246.161,36$ \\
30 & 2038 & - & $94.261,86$ & $-57.698,79$ & $36.563,07$ & $440.012,70$ & $2.321,46$ & $-243.839,89$ \\
\hline
\end{tabular}

Nota: Taxa de desconto de 10,75\% ao ano.

${ }^{1}$ Ano do projeto. ${ }^{2}$ Ano calendário. ${ }^{3}$ Entrada e saída de caixa devido à operação de crédito rural. ${ }^{4}$ Receita bruta das vendas. ${ }^{5}$ Desembolsos. ${ }^{6}$ Fluxo de caixa líquido (ESC+RB-D). ${ }^{7}$ Fluxo de caixa líquido acumulado não descontado. ${ }^{8}$ Fluxo de caixa líquido descontado. ${ }^{9}$ Fluxo de caixa líquido acumulado descontado.

A tabela 14 apresenta os resultados obtidos para o cenário 2. Neste, o Payback Simples ocorreu no $23^{\circ}$ ano do projeto. O Payback Descontado não ocorreu no prazo de análise. O VPL obtido foi de R\$167.809,35 negativos no final do período. A TIR obtida foi de $7,11 \%$ ao ano.

Tabela 14 - Projeção dos fluxos de caixa do empreendimento com a utilização de recursos de terceiros decorrentes de operação de crédito rural com pagamento dos juros incorporados ao valor inicial da dívida após o período de carência e receita bruta auferida a partir da venda de animais com a utilização da média mínima dos preços corrigidos - 2009-2038

\begin{tabular}{ccccccccc}
\multicolumn{6}{c}{ Continua } \\
\hline $\mathrm{AP}^{1}$ & $\mathrm{AC}^{2}$ & $\mathrm{ESC}^{3}$ & $\mathrm{RB}^{4}$ & $\mathrm{D}^{5}$ & $\mathrm{FCL}$ & $\mathrm{FCL}\left(\mathrm{AND}{ }^{7}\right)$ & $\mathrm{FCL}\left(\mathrm{D}^{8}\right)$ & $\mathrm{FCL}\left(\mathrm{AD}{ }^{9}\right)$ \\
\hline 1 & 2009 & - & - & $-12.435,99$ & $-12.435,99$ & $-12.435,99$ & $-15.253,44$ & $-15.253,44$ \\
2 & 2010 & $300.000,00$ & - & $-314.498,39$ & $14.337,61$ & $1.901,63$ & $15.878,91$ & 625,47 \\
3 & 2011 & - & $9.768,29$ & $-213.900,92$ & $-198.077,07$ & $-196.175,44$ & $-198.077,07$ & $-197.451,60$ \\
4 & 2012 & - & $58.075,70$ & $-56.084,89$ & $1.990,81$ & $-194.184,63$ & $1.797,57$ & $-195.654,03$ \\
5 & 2013 & - & $95.679,00$ & $-56.992,58$ & $38.686,42$ & $-155.498,21$ & $31.540,68$ & $-164.113,34$ \\
6 & 2014 & $-60.525,38$ & $98.922,83$ & $-59.956,30$ & $-21.558,85$ & $-177.057,06$ & $-15.870,64$ & $-179.983,98$ \\
7 & 2015 & $-60.525,38$ & $98.344,06$ & $-57.044,76$ & $-19.226,08$ & $-196.283,13$ & $-12.779,55$ & $-192.763,54$ \\
8 & 2016 & $-60.525,38$ & $94.092,24$ & $-57.493,19$ & $-23.926,33$ & $-220.209,47$ & $-14.360,10$ & $-207.123,63$ \\
9 & 2017 & $-60.525,38$ & $94.261,86$ & $-68.292,85$ & $-34.556,37$ & $-254.765,84$ & $-18.726,89$ & $-225.850,53$ \\
10 & 2018 & $-60.525,38$ & $94.261,86$ & $-57.698,79$ & $-23.962,31$ & $-278.728,15$ & $-11.725,26$ & $-237.575,79$ \\
11 & 2019 & $-60.525,38$ & $94.261,86$ & $-57.045,19$ & $-23.308,71$ & $-302.036,86$ & $-10.298,37$ & $-247.874,16$ \\
12 & 2020 & $-60.525,38$ & $94.261,86$ & $-57.698,79$ & $-23.962,31$ & $-325.999,18$ & $-9.559,50$ & $-257.433,66$ \\
13 & 2021 & $-60.525,38$ & $94.261,86$ & $-57.045,19$ & $-23.308,71$ & $-349.307,89$ & $-8.396,16$ & $-265.829,82$ \\
14 & 2022 & - & $94.261,86$ & $-57.495,81$ & $36.766,05$ & $-312.541,84$ & $11.958,20$ & $-253.871,62$ \\
15 & 2023 & - & $94.261,86$ & $-57.045,19$ & $37.216,67$ & $-275.325,17$ & $10.929,81$ & $-242.941,81$ \\
16 & 2024 & - & $94.261,86$ & $-57.698,79$ & $36.563,07$ & $-238.762,11$ & $9.695,59$ & $-233.246,22$ \\
\hline \hline
\end{tabular}


conclusão

\begin{tabular}{lllllllll}
\hline \hline 17 & 2025 & - & $94.261,86$ & $-68.292,85$ & $25.969,01$ & $-212.793,10$ & $6.217,89$ & $-227.028,33$ \\
18 & 2026 & - & $94.261,86$ & $-57.698,79$ & $36.563,07$ & $-176.230,03$ & $7.904,72$ & $-219.123,61$ \\
19 & 2027 & - & $94.261,86$ & $-57.045,19$ & $37.216,67$ & $-139.013,36$ & $7.265,04$ & $-211.858,58$ \\
20 & 2028 & - & $94.261,86$ & $-57.495,81$ & $36.766,05$ & $-102.247,32$ & $6.480,42$ & $-205.378,15$ \\
21 & 2029 & - & $94.261,86$ & $-57.045,19$ & $37.216,67$ & $-65.030,65$ & $5.923,12$ & $-199.455,04$ \\
22 & 2030 & - & $94.261,86$ & $-57.698,79$ & $36.563,07$ & $-28.467,58$ & $5.254,26$ & $-194.200,77$ \\
23 & 2031 & - & $94.261,86$ & $-57.045,19$ & $37.216,67$ & $8.749,09$ & $4.829,06$ & $-189.371,71$ \\
24 & 2032 & - & $94.261,86$ & $-57.495,81$ & $36.766,05$ & $45.515,14$ & $4.307,53$ & $-185.064,18$ \\
25 & 2033 & - & $94.261,86$ & $-68.292,85$ & $25.969,01$ & $71.484,14$ & $2.747,22$ & $-182.316,96$ \\
26 & 2034 & - & $94.261,86$ & $-57.495,81$ & $36.766,05$ & $108.250,19$ & $3.511,89$ & $-178.805,07$ \\
27 & 2035 & - & $94.261,86$ & $-57.045,19$ & $37.216,67$ & $145.466,86$ & $3.209,87$ & $-175.595,20$ \\
28 & 2036 & - & $94.261,86$ & $-57.698,79$ & $36.563,07$ & $182.029,92$ & $2.847,41$ & $-172.747,79$ \\
29 & 2037 & - & $94.261,86$ & $-57.045,19$ & $37.216,67$ & $219.246,59$ & $2.616,98$ & $-170.130,81$ \\
30 & 2038 & - & $94.261,86$ & $-57.698,79$ & $36.563,07$ & $255.809,66$ & $2.321,46$ & $-167.809,35$ \\
\hline NOta: & - & & - & & & & &
\end{tabular}

Nota: Taxa de desconto de 10,75\% ao ano.

${ }^{1}$ Ano do projeto. ${ }^{2}$ Ano calendário. ${ }^{3}$ Entrada e saída de caixa devido à operação de crédito rural. ${ }^{4}$ Receita bruta das vendas. ${ }^{5}$ Desembolsos. ${ }^{6}$ Fluxo de caixa líquido (ESC+RB-D). ${ }^{7}$ Fluxo de caixa líquido acumulado não descontado. ${ }^{8}$ Fluxo de caixa líquido descontado. ${ }^{9}$ Fluxo de caixa líquido acumulado descontado.

A tabela 15 apresenta fluxos de caixa projetados e memorial de cálculo obtido para o cenário 3. O VPL obtido foi de $\mathrm{R} \$ 177.258,23$ negativos no final do período. A TIR obtida foi de 7,50\% ao ano. O Payback Simples ocorreu no $23^{\circ}$ ano do projeto. O Payback Descontado não ocorreu no prazo de análise.

Tabela 15 - Projeção dos fluxos de caixa do empreendimento com a utilização de recursos de terceiros decorrentes de operação de crédito rural com pagamento dos juros devidos no período de carência e receita bruta auferida a partir da venda de animais com a utilização da média mínima dos preços corrigidos 2009-2038

\begin{tabular}{ccccccccc}
\hline \multicolumn{1}{c}{ continua } \\
\hline $\mathrm{AP}^{1}$ & $\mathrm{AC}^{2}$ & $\mathrm{ESC}^{3}$ & $\mathrm{RB}^{4}$ & $\mathrm{D}^{5}$ & $\mathrm{FCL}^{6}$ & $\mathrm{FCL}\left(\mathrm{AND}^{7}\right)$ & $\mathrm{FCL}\left(\mathrm{D}^{8}\right)$ & $\mathrm{FCL}\left(\mathrm{AD}{ }^{9}\right)$ \\
\hline 1 & 2009 & - & - & $-12.435,99$ & $-12.435,99$ & $-12.435,99$ & $-15.253,44$ & $-15.253,44$ \\
2 & 2010 & $300.000,00$ & - & $-314.498,39$ & $14.337,61$ & $1.901,63$ & $15.878,91$ & 625,47 \\
3 & 2011 & $-20.250,00$ & $9.768,29$ & $-213.900,92$ & $-218.327,07$ & $-216.425,44$ & $-218.327,07$ & $-217.701,60$ \\
4 & 2012 & $-20.250,00$ & $58.075,70$ & $-56.084,89$ & $-18.259,19$ & $-234.684,63$ & $-16.486,85$ & $-234.188,45$ \\
5 & 2013 & $-20.250,00$ & $95.679,00$ & $-56.992,58$ & $18.436,42$ & $-216.248,21$ & $15.031,04$ & $-219.157,41$ \\
6 & 2014 & $-49.754,67$ & $98.922,83$ & $-59.956,30$ & $-10.788,14$ & $-227.036,35$ & $-7.941,74$ & $-227.099,14$ \\
7 & 2015 & $-49.754,67$ & $98.344,06$ & $-57.044,76$ & $-8.455,37$ & $-235.491,71$ & $-5.620,27$ & $-232.719,41$ \\
8 & 2016 & $-49.754,67$ & $94.092,24$ & $-57.493,19$ & $-13.155,62$ & $-248.647,34$ & $-7.895,74$ & $-240.615,15$ \\
9 & 2017 & $-49.754,67$ & $94.261,86$ & $-68.292,85$ & $-23.785,66$ & $-272.433,00$ & $-12.890,00$ & $-253.505,15$ \\
10 & 2018 & $-49.754,67$ & $94.261,86$ & $-57.698,79$ & $-13.191,60$ & $-285.624,60$ & $-6.454,93$ & $-259.960,08$ \\
\hline \hline
\end{tabular}


conclusão

\begin{tabular}{|c|c|c|c|c|c|c|c|c|}
\hline 11 & 2019 & $-49.754,67$ & $94.261,86$ & $-57.045,19$ & $-12.538,00$ & -298.162,60 & $-5.539,60$ & $-265.499,68$ \\
\hline 12 & 2020 & $-49.754,67$ & $94.261,86$ & $-57.698,79$ & $-13.191,60$ & $-311.354,21$ & $-5.262,64$ & $-270.762,32$ \\
\hline 13 & 2021 & $-49.754,67$ & $94.261,86$ & $-57.045,19$ & $-12.538,00$ & $-323.892,21$ & $-4.516,39$ & $-275.278,71$ \\
\hline 14 & 2022 & - & $94.261,86$ & $-57.495,81$ & $36.766,05$ & $-287.126,16$ & $11.958,20$ & $-263.320,51$ \\
\hline 15 & 2023 & - & $94.261,86$ & $-57.045,19$ & $37.216,67$ & $-249.909,49$ & $10.929,81$ & $-252.390,69$ \\
\hline 16 & 2024 & - & $94.261,86$ & $-57.698,79$ & $36.563,07$ & $-213.346,43$ & $9.695,59$ & $-242.695,11$ \\
\hline 17 & 2025 & - & $94.261,86$ & $-68.292,85$ & $25.969,01$ & $-187.377,42$ & $6.217,89$ & $-236.477,22$ \\
\hline 18 & 2026 & - & $94.261,86$ & $-57.698,79$ & $36.563,07$ & $-150.814,35$ & $7.904,72$ & $-228.572,50$ \\
\hline 19 & 2027 & - & $94.261,86$ & $-57.045,19$ & $37.216,67$ & $-113.597,68$ & $7.265,04$ & $-221.307,46$ \\
\hline 20 & 2028 & - & $94.261,86$ & $-57.495,81$ & $36.766,05$ & $-76.831,64$ & $6.480,42$ & $-214.827,04$ \\
\hline 21 & 2029 & - & $94.261,86$ & $-57.045,19$ & $37.216,67$ & $-39.614,97$ & $5.923,12$ & $-208.903,92$ \\
\hline 22 & 2030 & - & $94.261,86$ & $-57.698,79$ & $36.563,07$ & $-3.051,90$ & $5.254,26$ & $-203.649,66$ \\
\hline 23 & 2031 & - & $94.261,86$ & $-57.045,19$ & $37.216,67$ & $34.164,77$ & $4.829,06$ & $-198.820,60$ \\
\hline 24 & 2032 & - & $94.261,86$ & $-57.495,81$ & $36.766,05$ & $70.930,82$ & $4.307,53$ & $-194.513,06$ \\
\hline 25 & 2033 & - & $94.261,86$ & $-68.292,85$ & $25.969,01$ & $96.899,82$ & $2.747,22$ & $-191.765,85$ \\
\hline 26 & 2034 & - & $94.261,86$ & $-57.495,81$ & $36.766,05$ & $133.665,87$ & $3.511,89$ & $-188.253,96$ \\
\hline 27 & 2035 & - & $94.261,86$ & $-57.045,19$ & $37.216,67$ & $170.882,54$ & $3.209,87$ & $-185.044,08$ \\
\hline 28 & 2036 & - & $94.261,86$ & $-57.698,79$ & $36.563,07$ & $207.445,60$ & $2.847,41$ & $-182.196,68$ \\
\hline 29 & 2037 & - & $94.261,86$ & $-57.045,19$ & $37.216,67$ & $244.662,27$ & $2.616,98$ & $-179.579,70$ \\
\hline 30 & 2038 & - & $94.261,86$ & $-57.698,79$ & $36.563,07$ & $281.225,34$ & $2.321,46$ & $-177.258,23$ \\
\hline
\end{tabular}

Nota: Taxa de desconto de 10,75\% ao ano.

${ }^{1}$ Ano do projeto. ${ }^{2}$ Ano calendário. ${ }^{3}$ Entrada e saída de caixa devido à operação de crédito rural. ${ }^{4}$ Receita bruta das vendas. ${ }^{5}$ Desembolsos. ${ }^{6}$ Fluxo de caixa líquido (ESC+RB-D). ${ }^{7}$ Fluxo de caixa líquido acumulado não descontado. ${ }^{8}$ Fluxo de caixa líquido descontado. ${ }^{9}$ Fluxo de caixa líquido acumulado descontado.

Para o cenário 4, conforme apresentado na tabela 16, Payback Descontado não ocorreu no prazo de análise. O valor para o VPL foi de R\$ 83.491,57 negativos e a TIR apurada foi de 8,95\% ao ano. Verificou-se que o Payback Simples ocorreu no $13^{\circ}$ ano do projeto.

Tabela 16 - Projeção dos fluxos de caixa do empreendimento com a utilização de recursos próprios e receita bruta auferida a partir da venda de animais com a utilização da média geral dos preços corrigidos - 2009-2038

continua

\begin{tabular}{ccccccccc}
\hline $\mathrm{AP}^{1}$ & $\mathrm{AC}^{2}$ & $\mathrm{ESC}^{3}$ & $\mathrm{RB}^{4}$ & $\mathrm{D}^{5}$ & $\mathrm{FCL}$ & $\left.\mathrm{FCL}(\mathrm{AND})^{7}\right)$ & $\mathrm{FCL}\left(\mathrm{D}^{8}\right)$ & $\mathrm{FCL}\left(\mathrm{AD}{ }^{9}\right)$ \\
\hline 1 & 2009 & - & - & $-12.435,99$ & $-12.435,99$ & $-12.435,99$ & $-15.253,44$ & $-15.253,44$ \\
2 & 2010 & - & - & $-314.498,39$ & $-303.794,39$ & $-316.230,37$ & $-336.452,28$ & $-351.705,72$ \\
3 & 2011 & - & $12.002,61$ & $-213.900,92$ & $-199.650,47$ & $-515.880,85$ & $-199.650,47$ & $-551.356,19$ \\
4 & 2012 & - & $71.359,44$ & $-56.084,89$ & $15.274,55$ & $-500.606,29$ & $13.791,92$ & $-537.564,27$ \\
5 & 2013 & - & $117.563,80$ & $-56.992,58$ & $60.571,22$ & $-440.035,07$ & $49.383,16$ & $-488.181,12$ \\
6 & 2014 & - & $121.549,59$ & $-59.956,30$ & $61.593,29$ & $-378.441,78$ & $45.342,16$ & $-442.838,95$ \\
\hline \hline
\end{tabular}


conclusão

\begin{tabular}{ccccccccc}
\hline \hline 7 & 2015 & - & $120.838,44$ & $-57.044,76$ & $63.793,68$ & $-314.648,10$ & $42.403,60$ & $-400.435,35$ \\
8 & 2016 & - & $115.614,09$ & $-57.493,19$ & $58.120,90$ & $-256.527,19$ & $34.882,99$ & $-365.552,36$ \\
9 & 2017 & - & $115.822,51$ & $-68.292,85$ & $47.529,66$ & $-208.997,54$ & $25.757,42$ & $-339.794,95$ \\
10 & 2018 & - & $115.822,51$ & $-57.698,79$ & $58.123,72$ & $-150.873,82$ & $28.441,16$ & $-311.353,79$ \\
11 & 2019 & - & $115.822,51$ & $-57.045,19$ & $58.777,32$ & $-92.096,50$ & $25.969,28$ & $-285.384,51$ \\
12 & 2020 & - & $115.822,51$ & $-57.698,79$ & $58.123,72$ & $-33.972,78$ & $23.187,81$ & $-262.196,70$ \\
13 & 2021 & - & $115.822,51$ & $-57.045,19$ & $58.777,32$ & $24.804,54$ & $21.172,51$ & $-241.024,19$ \\
14 & 2022 & - & $115.822,51$ & $-57.495,81$ & $58.326,70$ & $83.131,24$ & $18.970,83$ & $-222.053,36$ \\
15 & 2023 & - & $115.822,51$ & $-57.045,19$ & $58.777,32$ & $141.908,56$ & $17.261,76$ & $-204.791,60$ \\
16 & 2024 & - & $115.822,51$ & $-57.698,79$ & $58.123,72$ & $200.032,28$ & $15.412,92$ & $-189.378,69$ \\
17 & 2025 & - & $115.822,51$ & $-68.292,85$ & $47.529,66$ & $247.561,94$ & $11.380,27$ & $-177.998,42$ \\
18 & 2026 & - & $115.822,51$ & $-57.698,79$ & $58.123,72$ & $305.685,66$ & $12.566,01$ & $-165.432,41$ \\
19 & 2027 & - & $115.822,51$ & $-57.045,19$ & $58.777,32$ & $364.462,97$ & $11.473,87$ & $-153.958,54$ \\
20 & 2028 & - & $115.822,51$ & $-57.495,81$ & $58.326,70$ & $422.789,67$ & $10.280,73$ & $-143.677,81$ \\
21 & 2029 & - & $115.822,51$ & $-57.045,19$ & $58.777,32$ & $481.566,99$ & $9.354,54$ & $-134.323,27$ \\
22 & 2030 & - & $115.822,51$ & $-57.698,79$ & $58.123,72$ & $539.690,71$ & $8.352,61$ & $-125.970,65$ \\
23 & 2031 & - & $115.822,51$ & $-57.045,19$ & $58.777,32$ & $598.468,03$ & $7.626,67$ & $-118.343,98$ \\
24 & 2032 & - & $115.822,51$ & $-57.495,81$ & $58.326,70$ & $656.794,73$ & $6.833,59$ & $-111.510,39$ \\
25 & 2033 & - & $115.822,51$ & $-68.292,85$ & $47.529,66$ & $704.324,39$ & $5.028,08$ & $-106.482,31$ \\
26 & 2034 & - & $115.822,51$ & $-57.495,81$ & $58.326,70$ & $762.651,09$ & $5.571,36$ & $-100.910,94$ \\
27 & 2035 & - & $115.822,51$ & $-57.045,19$ & $58.777,32$ & $821.428,41$ & $5.069,44$ & $-95.841,50$ \\
28 & 2036 & - & $115.822,51$ & $-57.698,79$ & $58.123,72$ & $879.552,13$ & $4.526,47$ & $-91.315,03$ \\
29 & 2037 & - & $115.822,51$ & $-57.045,19$ & $58.777,32$ & $938.329,44$ & $4.133,07$ & $-87.181,96$ \\
30 & 2038 & - & $115.822,51$ & $-57.698,79$ & $58.123,72$ & $996.453,16$ & $3.690,39$ & $-83.491,57$ \\
\hline
\end{tabular}

Nota: Taxa de desconto de 10,75\% ao ano.

${ }^{1}$ Ano do projeto. ${ }^{2}$ Ano calendário. ${ }^{3}$ Entrada e saída de caixa devido à operação de crédito rural. ${ }^{4}$ Receita bruta das vendas. ${ }^{5}$ Desembolsos. ${ }^{6}$ Fluxo de caixa líquido (ESC+RB-D). ${ }^{7}$ Fluxo de caixa líquido acumulado não descontado. ${ }^{8}$ Fluxo de caixa líquido descontado. ${ }^{9}$ Fluxo de caixa líquido acumulado descontado.

A tabela 17 apresenta fluxos de caixa projetados e memorial de cálculo obtido para o cenário 5. Para este, o Payback Descontado não ocorreu no prazo de análise. O valor para o VPL foi de R\$7.461,02 negativos e a TIR apurada foi de $10,62 \%$ ao ano. Verificou-se que o Payback Simples ocorreu no $16^{\circ}$ ano do projeto. 
Tabela 17 - Projeção dos fluxos de caixa do empreendimento com a utilização de recursos de terceiros decorrentes de operação de crédito rural com pagamento dos juros incorporados ao valor inicial da dívida após o período de carência e receita bruta auferida a partir da venda de animais com a utilização da média geral dos preços corrigidos - 2009-2038

\begin{tabular}{|c|c|c|c|c|c|c|c|c|}
\hline $\mathrm{AP}^{1}$ & $A C^{2}$ & $\mathrm{ESC}^{3}$ & $\mathrm{RB}^{4}$ & $D^{5}$ & $\mathrm{FCL}^{6}$ & $\mathrm{FCL}\left(\mathrm{AND}^{7}\right)$ & $\mathrm{FCL}\left(\mathrm{D}^{8}\right)$ & $\mathrm{FCL}\left(A D^{9}\right)$ \\
\hline 1 & 2009 & - & - & $-12.435,99$ & $-12.435,99$ & $-12.435,99$ & $-15.253,44$ & $-15.253,44$ \\
\hline 2 & 2010 & $300.000,00$ & - & $-314.498,39$ & $-3.794,39$ & $-16.230,37$ & $-4.202,28$ & $-19.455,72$ \\
\hline 3 & 2011 & - & $12.002,61$ & $-213.900,92$ & $-199.650,47$ & $-215.880,85$ & $-199.650,47$ & $-219.106,19$ \\
\hline 4 & 2012 & - & $71.359,44$ & $-56.084,89$ & $15.274,55$ & $-200.606,29$ & $13.791,92$ & $-205.314,27$ \\
\hline 5 & 2013 & - & $117.563,80$ & $-56.992,58$ & $60.571,22$ & $-140.035,07$ & $49.383,16$ & $-155.931,12$ \\
\hline 6 & 2014 & $-60.525,38$ & $121.549,59$ & $-59.956,30$ & $1.067,91$ & $-138.967,16$ & 786,15 & $-155.144,97$ \\
\hline 7 & 2015 & $-60.525,38$ & $120.838,44$ & $-57.044,76$ & $3.268,30$ & $-135.698,86$ & $2.172,44$ & $-152.972,53$ \\
\hline 8 & 2016 & $-60.525,38$ & $115.614,09$ & $-57.493,19$ & $-2.404,48$ & $-138.103,33$ & $-1.443,12$ & $-154.415,65$ \\
\hline 9 & 2017 & $-60.525,38$ & $115.822,51$ & $-68.292,85$ & $-12.995,72$ & $-151.099,06$ & $-7.042,68$ & $-161.458,33$ \\
\hline 10 & 2018 & $-60.525,38$ & $115.822,51$ & $-57.698,79$ & -2.40 & 0,72 & -1.1 & 33,51 \\
\hline 11 & 2019 & $-60.525,38$ & $115.822,51$ & $-57.045,19$ & $-1.748,06$ & $-155.248,78$ & $-772,34$ & $-163.405,85$ \\
\hline 12 & 2020 & $-60.525,38$ & $115.822,51$ & $-57.698,79$ & $-2.401,66$ & $-157.650,44$ & $-958,12$ & 363,96 \\
\hline 13 & 2021 & $-60.525,38$ & $115.822,51$ & $-57.045,19$ & $-1.748,06$ & $-159.398,50$ & $-629,68$ & $-164.993,64$ \\
\hline 14 & 2022 & - & $115.822,51$ & $-57.495,81$ & $58.326,70$ & $-101.071,80$ & $18.970,83$ & $-146.022,81$ \\
\hline 15 & 2023 & - & $115.822,51$ & $-57.045,19$ & 58.77 & 4,48 & $17.261,76$ & 1,06 \\
\hline 16 & 2024 & - & $115.822,51$ & $-57.698,79$ & $58.123,72$ & $15.829,24$ & $15.412,92$ & $-113.348,14$ \\
\hline 17 & 2025 & - & $115.822,51$ & $-68.292,85$ & $47.529,66$ & 58,90 & $11.380,27$ & 67,87 \\
\hline 18 & 2026 & - & $115.822,51$ & $-57.698,79$ & $58.123,72$ & $121.482,62$ & $12.566,01$ & $-89.401,87$ \\
\hline 19 & 2027 & - & $115.822,51$ & $-57.045,19$ & $58.777,32$ & $180.259,93$ & $11.473,87$ & $-77.927,99$ \\
\hline 20 & 2028 & - & $115.822,51$ & $-57.495,81$ & 58.326 & $238.586,63$ & $10.280,73$ & $-67.647,26$ \\
\hline 21 & 2029 & - & $115.822,51$ & $-57.045,19$ & $58.777,32$ & $297.363,95$ & $9.354,54$ & $-58.292,72$ \\
\hline 22 & 2030 & - & $115.822,51$ & $-57.698,79$ & $58.123,72$ & $355.487,67$ & $8.352,61$ & $-49.940,11$ \\
\hline 23 & 2031 & - & $115.822,51$ & $-57.045,19$ & $58.777,32$ & 4,99 & $7.626,67$ & 313,44 \\
\hline 24 & 2032 & - & $115.822,51$ & $-57.495,81$ & $58.326,70$ & $472.591,69$ & $6.833,59$ & $-35.479,84$ \\
\hline 25 & 2033 & - & $115.822,51$ & $-68.292,85$ & $47.529,66$ & $520.121,35$ & $5.028,08$ & $-30.451,76$ \\
\hline 26 & 2034 & - & $115.822,51$ & $-57.495,81$ & $58.326,70$ & $578.448,05$ & $5.571,36$ & $-24.880,40$ \\
\hline 27 & 2035 & - & $115.822,51$ & $-57.045,19$ & $58.777,32$ & $637.225,37$ & $5.069,44$ & $-19.810,96$ \\
\hline 28 & 2036 & - & $115.822,51$ & $-57.698,79$ & $58.123,72$ & $.349,09$ & $4.526,47$ & $-15.284,48$ \\
\hline 29 & 2037 & - & $115.822,51$ & $-57.045,19$ & $58.777,32$ & $754.126,40$ & $4.133,07$ & $-11.151,41$ \\
\hline 30 & 2038 & - & $115.822,51$ & $-57.698,79$ & $58.123,72$ & $812.250,12$ & $3.690,39$ & $-7.461,02$ \\
\hline
\end{tabular}

Nota: Taxa de desconto de $10,75 \%$ ao ano.

${ }^{1}$ Ano do projeto. ${ }^{2}$ Ano calendário. ${ }^{3}$ Entrada e saída de caixa devido à operação de crédito rural. ${ }^{4}$ Receita bruta das vendas. ${ }^{5}$ Desembolsos. ${ }^{6}$ Fluxo de caixa líquido (ESC+RB-D). ${ }^{7}$ Fluxo de caixa líquido acumulado não descontado. ${ }^{8}$ Fluxo de caixa líquido descontado. ${ }^{9}$ Fluxo de caixa líquido acumulado descontado.

A tabela 18 apresenta os resultados obtidos para o cenário 6 , no qual o Payback Descontado não ocorreu no prazo de análise. O valor para o VPL foi de 
$\mathrm{R} \$ 16.909,91$ negativos e a TIR apurada foi de 10,42\% ao ano. Verificou-se que o Payback Simples ocorreu no $16^{\circ}$ ano do projeto.

Tabela 18 - Projeção dos fluxos de caixa do empreendimento com a utilização de recursos de terceiros decorrentes de operação de crédito rural com pagamento dos juros devidos no período de carência e receita bruta auferida a partir da venda de animais com a utilização da média geral dos preços corrigidos - 2009-2038

\begin{tabular}{|c|c|c|c|c|c|c|c|c|}
\hline$\overline{A P^{1}}$ & $A C^{2}$ & $\mathrm{SC}^{3}$ & $\overline{\mathrm{RB}^{4}}$ & $D^{5}$ & $\overline{\mathrm{FCL}^{6}}$ & $\mathrm{FCL}\left(\mathrm{AND}^{7}\right)$ & $\left.D^{8}\right)$ & $\overline{F C L}$ \\
\hline 1 & 09 & & & $-12.435,99$ & $-12.435,99$ & $-12.435,99$ & $-15.253,44$ & $-15.253,44$ \\
\hline 2 & 2010 & o & - & $-314.498,39$ & -3 & & & ,72 \\
\hline 3 & 2011 & $0.250,00$ & $12.002,61$ & -213. & $-219.900,47$ & -236. & -219 & -239 \\
\hline 4 & 2012 & $-20.250,00$ & $71.359,44$ & $-56.084,89$ & $-4.975,45$ & $-241.106,29$ & $-4.492,50$ & $-243.848,70$ \\
\hline 5 & 2013 & -20.25 & $117.563,80$ & $-56 . \varsigma$ & 40.3 & -200 & 32 & -21 \\
\hline 6 & 2014 & $-49.754,67$ & $121.549,59$ & $-59.956,30$ & 11.838 & -188 & 8.71 & -202 \\
\hline 7 & 2015 & $-49.754,67$ & $120.838,44$ & $-57.044,76$ & $14.039,01$ & -174 & 9.33 & -19 \\
\hline 8 & 2016 & -49.7 & $115.614,09$ & -57. & $8.366,23$ & -166. & 5.0 & -187 \\
\hline 9 & 2017 & $-49.754,67$ & 115.82 & -68.2 & -2.2 & $-168.766,22$ & $-1.205,79$ & -189. \\
\hline 10 & 2018 & $-49.754,67$ & $15.822,51$ & -57. & 8.36 & -160 & 4.0 & -18 \\
\hline 11 & 2019 & -49.7 & 115.82 & -57. & 9.0 & -15 & & -18 \\
\hline 12 & 2020 & $-49.754,67$ & 115.82 & -5 & $8.369,05$ & $-143.005,47$ & $3.338,74$ & $-177.692,63$ \\
\hline 13 & 2021 & $-49.754,67$ & $115.822,51$ & $-57.045,19$ & $9.022,65$ & $-133.982,82$ & 3.25 & -174 \\
\hline 14 & 2022 & - & 1 & -57.4 & $58.326,70$ & & & -15 \\
\hline 15 & 2023 & - & 1 & -57 & $5 \varepsilon$ & -16 & 76 & -13 \\
\hline 16 & 2024 & - & $115.822,51$ & -57.6 & $58.123,72$ & $41.244,92$ & $15.412,92$ & $-122.797,03$ \\
\hline 17 & 25 & - & 15.82 & -68 & 6 & $8 \varepsilon$ & 27 & -1 \\
\hline 18 & 2026 & - & & -57.6 & 50 & 30 & & -98 \\
\hline 19 & 2027 & 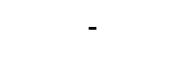 & $115.822,51$ & -57 & $58.777,32$ & $205.675,61$ & $11.473,87$ & $-87.376,88$ \\
\hline 20 & & - & $115.822,51$ & -57 & $58.326,70$ & 264. & 0,73 & $-77.096,15$ \\
\hline 21 & 2029 & - & & -57 & & & & \\
\hline 22 & 2030 & - & $15.822,51$ & -57 & $58.123,72$ & 380 & 8.35 & $-59.388,99$ \\
\hline 23 & 2031 & - & $115.822,51$ & -57 & $58.777,32$ & $439.680,67$ & $7.626,67$ & $-51.762,32$ \\
\hline 24 & & - & 5.82 & -57 & 70 & 37 & 6. & -44 \\
\hline 25 & 2033 & - & $15.822,51$ & -68 & & $545.537,03$ & - & -3 \\
\hline 26 & 2034 & - & 51 & -57 & 70 & ,73 & 36 & -34.3 \\
\hline 27 & 2035 & - & $115.822,51$ & 19 & $58.777,32$ & $662.641,05$ & $5.069,44$ & $-29.259,84$ \\
\hline 28 & 36 & - & $5.822,51$ & -5 & $58.123,72$ & $720.764,77$ & $4.526,47$ & $-24.733,37$ \\
\hline 29 & & - & $15.822,51$ & -57 & $58.777,32$ & $779.542,08$ & $4.133,07$ & $-20.600,30$ \\
\hline 30 & 2038 & & $115.822,51$ & $-57.698,79$ & $58.123,72$ & $837.665,80$ & $3.690,39$ & $-16.909,91$ \\
\hline
\end{tabular}

Nota: Taxa de desconto de 10,75\% ao ano.

${ }^{1}$ Ano do projeto. ${ }^{2}$ Ano calendário. ${ }^{3}$ Entrada e saída de caixa devido à operação de crédito rural. ${ }^{4}$ Receita bruta das vendas. ${ }^{5}$ Desembolsos. ${ }^{6}$ Fluxo de caixa líquido (ESC+RB-D). ${ }^{7}$ Fluxo de caixa líquido acumulado não descontado. ${ }^{8}$ Fluxo de caixa líquido descontado. ${ }^{9}$ Fluxo de caixa líquido acumulado descontado. 
Para o cenário 7, conforme apresentado na tabela 19. O valor para o VPL foi de $\mathrm{R} \$ 17.323,07$ e a TIR apurada foi de $11,10 \%$ ao ano. Verificou-se que 0 Payback Simples ocorreu no $11^{\circ}$ ano do projeto e o Payback Descontado no $27^{\circ}$ ano do projeto.

Tabela 19 - Projeção dos fluxos de caixa do empreendimento com a utilização de recursos próprios e receita bruta auferida a partir da venda de animais com a utilização da média máxima dos preços corrigidos - 2009-2038

\begin{tabular}{|c|c|c|c|c|c|c|c|c|}
\hline$\overline{A P^{1}}$ & $A C^{2}$ & $c^{3}$ & $3^{4}$ & $D^{5}$ & $\mathrm{FCL}^{6}$ & L $\left(\right.$ AND $\left.^{7}\right)$ & $\overline{F C L}\left(D^{8}\right)$ & $\overline{F C L}\left(A D^{9}\right)$ \\
\hline 1 & 2009 &  & 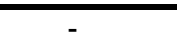 & $-12.435,99$ & $-12.435,99$ & $-12.435,99$ & $-15.253,44$ & $-15.253,44$ \\
\hline 2 & 2010 & - & - & $-315.194,39$ & $-315.194,39$ & $-327.630,37$ & $-349.077,78$ & $-364.331,22$ \\
\hline 3 & 2011 & - & $13.407,37$ & -214.047 & 200.63 & $-528.270,08$ & $-200.639,71$ & -564 \\
\hline 4 & 2012 & - & $79.711,23$ & $-56.084,89$ & $23.626,34$ & $-504.643,74$ & $21.333,04$ & $-543.637,89$ \\
\hline 5 & 2013 & - & $131.323,27$ & $-56.992,58$ & $74.330,69$ & $-430.313,05$ & $60.601,12$ & $-483.036,76$ \\
\hline 6 & 2014 & - & 135.775 & $-59.956,30$ & $75.819,25$ & $-354.493,80$ & $55.814,66$ & -427 \\
\hline 7 & 2015 & - & 4.98 & $-57.044,76$ & $77.936,41$ & 57,39 & 51.8 & -375 \\
\hline 8 & 2016 & - & $9.145,37$ & $-57.493,19$ & $71.652,18$ & $-204.905,20$ & $43.004,19$ & $-332.413,66$ \\
\hline 9 & 2017 & - & 129.3 & $-68.292,85$ & $61.085,33$ & $-143.819,88$ & $33.103,55$ & -299. \\
\hline 10 & 2018 & - & $129.378,18$ & $-57.698,79$ & $71.679,39$ & $-72.140,49$ & 4,23 & -264 \\
\hline 11 & 2019 & - & 9.3 & -57.0 & $72.332,99$ & 192,50 & 31.9 & $-232.277,37$ \\
\hline 12 & 2020 & - & 8 & 8,79 & ,39 & ,89 & 70 & -203 \\
\hline 13 & 2021 & - & $129.378,18$ & $-57.045,19$ & $72.332,99$ & $144.204,88$ & $26.055,48$ & $-177.626,19$ \\
\hline 14 & 2022 & - & $129.378,18$ & $-57.495,81$ & $71.882,37$ & $216.087,25$ & $23.379,83$ & -154 \\
\hline 15 & 2023 & - & $B$ & -57 & 99 & 25 & & -13 \\
\hline 16 & $2 c$ & - & $129.378,18$ & $-57.698,79$ & $71.679,39$ & $360.099,64$ & $19.007,53$ & $-113.996,04$ \\
\hline 17 & 2025 & - & $129.378,18$ & $-68.292,85$ & $61.085,33$ & $421.184,96$ & $14.625,97$ & $-99.370,07$ \\
\hline 18 & 2026 & - & 1 & & 39 & 35 & 67 & 40 \\
\hline 19 & 2027 & - & $129.378,18$ & $-57.045,19$ & $72.332,99$ & $565.197,34$ & $14.120,06$ & $-69.753,34$ \\
\hline 20 & $2 c$ & - & $129.378,18$ & $-57.495,81$ & $71.882,37$ & $637.079,71$ & $12.670,07$ & $-57.083,27$ \\
\hline 21 & 2 & - & 129.3 & $-57.045,19$ & $72.332,99$ & $709.412,70$ & $11.511,96$ & 11,32 \\
\hline 22 & $2 C$ & - & & $-57.698,79$ & 71.6 & 781.0 & 10.30 & 0,70 \\
\hline 23 & 203 & - & $129.378,18$ & $-57.045,19$ & $72.332,99$ & $853.425,08$ & $9.385,59$ & $-25.885,10$ \\
\hline 24 & 2032 & - & $129.378,18$ & $-57.495,81$ & $71.882,37$ & $925.307,46$ & $8.421,78$ & $-17.463,32$ \\
\hline 25 & & - & 129. & $-68.292,85$ & $.085,33$ & $986.392,78$ & $6.462,12$ & $-11.001,21$ \\
\hline 26 & 203 & - & $129.378,18$ & $-57.495,81$ & 37 & 15 & 866,20 & $-4.135,01$ \\
\hline 27 & 2035 & - & $129.378,18$ & $-57.045,19$ & $72.332,99$ & $130.608,14$ & $6.238,59$ & $2.103,59$ \\
\hline 28 & 203 & - & $129.378,18$ & $-57.698,79$ & $71.679,39$ & $1.202 .287,53$ & $5.582,14$ & $7.685,73$ \\
\hline 29 & & - & $129.378,18$ & $-57.045,19$ & $72.332,99$ & $1.274 .620,52$ & $5.086,27$ & $12.772,00$ \\
\hline 30 & 2038 & - & $129.378,18$ & $-57.698,79$ & $71.679,39$ & $1.346 .299,91$ & $4.551,07$ & $17.323,07$ \\
\hline
\end{tabular}

Nota: Taxa de desconto de $10,75 \%$ ao ano.

${ }^{1}$ Ano do projeto. ${ }^{2}$ Ano calendário. ${ }^{3}$ Entrada e saída de caixa devido à operação de crédito rural. ${ }^{4}$ Receita bruta das vendas. ${ }^{5}$ Desembolsos. ${ }^{6}$ Fluxo de caixa líquido 
(ESC+RB-D). ${ }^{7}$ Fluxo de caixa líquido acumulado não descontado. ${ }^{8}$ Fluxo de caixa líquido descontado. ${ }^{9}$ Fluxo de caixa líquido acumulado descontado.

Para o cenário 8, o valor para o VPL foi de $\mathrm{R} \$ 93.353,61$ e a TIR apurada foi de $14,35 \%$ ao ano. Verificou-se que o Payback Simples ocorreu no $14^{\circ}$ ano do projeto e o Payback Descontado no $19^{\circ}$ ano do projeto, conforme apresentado na tabela 20.

Tabela 20 - Projeção dos fluxos de caixa do empreendimento com a utilização de recursos de terceiros decorrentes de operação de crédito rural com pagamento dos juros incorporados ao valor inicial da dívida após o período de carência e receita bruta auferida a partir da venda de animais com a utilização da média máxima dos preços corrigidos - 2009-2038

\begin{tabular}{|c|c|c|c|c|c|c|c|c|}
\hline $\mathrm{AP}^{1}$ & $A C^{2}$ & $\mathrm{ESC}^{3}$ & $\mathrm{RB}^{4}$ & $\mathrm{D}^{5}$ & $\mathrm{FCL}^{6}$ & $\mathrm{FCL}\left(\mathrm{AND}^{\prime}\right)$ & $\mathrm{FCL}\left(\mathrm{D}^{8}\right)$ & $\mathrm{FCL}\left(\mathrm{AD}^{9}\right)$ \\
\hline 1 & 2009 & - & - & $-12.435,99$ & $-12.435,99$ & $-12.435,99$ & $-15.253,44$ & $-15.253,44$ \\
\hline 2 & 2010 & $300.000,00$ & - & $-315.194,39$ & $-15.194,39$ & $-27.630,37$ & $-16.827,78$ & $-32.081,22$ \\
\hline 3 & 2011 & - & 13.40 & $-214.047,08$ & $-200.639,71$ & $-228.270,08$ & $-200.639,71$ & $-232.720,93$ \\
\hline 4 & 2012 & - & $79.711,23$ & $-56.084,89$ & $23.626,34$ & $-204.643,74$ & $21.333,04$ & $-211.387,89$ \\
\hline 5 & 2013 & - & $131.323,27$ & $-56.992,58$ & $74.330,69$ & $-130.313,05$ & $60.601,12$ & $-150.786,76$ \\
\hline 6 & 2014 & $-60.525,38$ & $135.775,55$ & $-59.956,30$ & $15.293,87$ & $-115.019,18$ & $11.258,65$ & $-139.528,12$ \\
\hline 7 & 2015 & $-60.525,38$ & $134.981,17$ & $-57.044,76$ & $17.411,03$ & $-97.608,15$ & $11.573,10$ & $-127.955,02$ \\
\hline 8 & 2016 & $-60.525,38$ & $129.145,37$ & $-57.493,19$ & $11.126,80$ & $-86.481,34$ & $6.678,08$ & $-121.276,94$ \\
\hline 9 & 2017 & $-60.525,38$ & $129.378,18$ & $-68.292,85$ & 559,95 & $-85.921,40$ & 303,45 & $-120.973,49$ \\
\hline 10 & 2018 & $-60.525,38$ & $129.378,18$ & $-57.698,79$ & $11.154,01$ & $-74.767,39$ & $5.457,89$ & $-115.515,60$ \\
\hline 11 & 2019 & $-60.525,38$ & $129.378,18$ & $-57.045,19$ & $11.807,61$ & $-62.959,78$ & $5.216,90$ & $-110.298,70$ \\
\hline 12 & 2020 & $-60.525,38$ & $129.378,18$ & $-57.698,79$ & $11.154,01$ & $-51.805,77$ & $4.449,77$ & $-105.848,93$ \\
\hline 13 & 2021 & $-60.525,38$ & $129.378,18$ & $-57.045,19$ & $11.807,61$ & $-39.998,16$ & $4.253,29$ & $-101.595,65$ \\
\hline 14 & 2022 & - & $129.378,18$ & $-57.495,81$ & $71.882,37$ & $31.884,21$ & $23.379,83$ & $-78.215,82$ \\
\hline 15 & 2023 & - & $129.378,18$ & $-57.045,19$ & $72.332,99$ & $104.217,21$ & $21.242,79$ & $-56.973,03$ \\
\hline 16 & 2024 & - & 129. & $-57.698,79$ & $71.679,39$ & $175.896,60$ & $19.007,53$ & $-37.965,49$ \\
\hline 17 & 2025 & - & $129.378,18$ & $-68.292,85$ & $61.085,33$ & $236.981,92$ & $14.625,97$ & $-23.339,53$ \\
\hline 18 & 2026 & - & $129.378,18$ & $-57.698,79$ & $71.679,39$ & $308.661,31$ & $15.496,67$ & $-7.842,86$ \\
\hline 19 & 2027 & - & 12 & 19 & 99 & 30 & 06 &, 20 \\
\hline 20 & 2028 & - & $129.378,18$ & $-57.495,81$ & $71.882,37$ & $452.876,67$ & $12.670,07$ & $18.947,27$ \\
\hline 21 & 2029 & - & $129.378,18$ & $-57.045,19$ & $72.332,99$ & $525.209,66$ & $11.511,96$ & $30.459,23$ \\
\hline 22 & 2030 & - & $129.378,18$ & $-57.698,79$ & $71.679,39$ & $596.889,05$ & $10.300,62$ & $40.759,85$ \\
\hline 23 & 2031 & - & $129.378,18$ & $-57.045,19$ & $72.332,99$ & $669.222,04$ & $9.385,59$ & $50.145,44$ \\
\hline 24 & 2032 & - & $129.378,18$ & $-57.495,81$ & $71.882,37$ & $741.104,42$ & $8.421,78$ & $58.567,22$ \\
\hline 25 & 2033 & - & $129.378,18$ & $-68.292,85$ & $61.085,33$ & $802.189,74$ & $6.462,12$ & $65.029,34$ \\
\hline 26 & 2034 & - & $129.378,18$ & $-57.495,81$ & $71.882,37$ & $874.072,11$ & $6.866,20$ & $71.895,54$ \\
\hline 27 & 2035 & - & $129.378,18$ & $-57.045,19$ & $72.332,99$ & $946.405,10$ & $6.238,59$ & $78.134,13$ \\
\hline 28 & 2036 & - & $129.378,18$ & $-57.698,79$ & $71.679,39$ & $1.018 .084,49$ & $5.582,14$ & $83.716,28$ \\
\hline
\end{tabular}


conclusão

\begin{tabular}{lllllllll}
\hline \hline 29 & 2037 & - & $129.378,18$ & $-57.045,19$ & $72.332,99$ & $1.090 .417,48$ & $5.086,27$ & $88.802,55$ \\
30 & 2038 & - & $129.378,18$ & $-57.698,79$ & $71.679,39$ & $1.162 .096,87$ & $4.551,07$ & $93.353,61$ \\
\hline
\end{tabular}

Nota: Taxa de desconto de $10,75 \%$ ao ano.

${ }^{1}$ Ano do projeto. ${ }^{2}$ Ano calendário. ${ }^{3}$ Entrada e saída de caixa devido à operação de crédito rural. ${ }^{4}$ Receita bruta das vendas. ${ }^{5}$ Desembolsos. ${ }^{6}$ Fluxo de caixa líquido (ESC+RB-D). ${ }^{7}$ Fluxo de caixa líquido acumulado não descontado. ${ }^{8}$ Fluxo de caixa líquido descontado. ${ }^{9}$ Fluxo de caixa líquido acumulado descontado.

Para o cenário 9, o valor para o VPL foi de $\mathrm{R} \$ 83.904,73$ e a TIR apurada foi de $13,65 \%$ ao ano. Verificou-se que o Payback Simples ocorreu no $14^{\circ}$ ano do projeto e o Payback Descontado no $20^{\circ}$ ano do projeto, conforme apresentado na tabela 21.

Tabela 21 - Projeção dos fluxos de caixa do empreendimento com a utilização de recursos de terceiros decorrentes de operação de crédito rural com pagamento dos juros devidos no período de carência e receita bruta auferida a partir da venda de animais com a utilização da média máxima dos preços corrigidos - 20092038

\begin{tabular}{ccccccccc}
\multicolumn{6}{c}{ continua } \\
\hline $\mathrm{AP}^{1}$ & $\mathrm{AC}^{2}$ & $\mathrm{EC}^{3}$ & $\mathrm{RB}^{4}$ & \multicolumn{1}{c}{$\mathrm{D}^{5}$} & \multicolumn{1}{c}{$\mathrm{FCL}$} & $\mathrm{FCL}\left(\mathrm{AND}^{7}\right)$ & \multicolumn{1}{c}{$\mathrm{FCL}\left(\mathrm{D}^{8}\right)$} & \multicolumn{1}{c}{$\mathrm{FCL}\left(\mathrm{AD}^{9}\right)$} \\
\hline 1 & 2009 & - & - & $-12.435,99$ & $-12.435,99$ & $-12.435,99$ & $-15.253,44$ & $-15.253,44$ \\
2 & 2010 & $300.000,00$ & - & $-315.194,39$ & $-15.194,39$ & $-27.630,37$ & $-16.827,78$ & $-32.081,22$ \\
3 & 2011 & $-20.250,00$ & $13.407,37$ & $-214.047,08$ & $-220.889,71$ & $-248.520,08$ & $-220.889,71$ & $-252.970,93$ \\
4 & 2012 & $-20.250,00$ & $79.711,23$ & $-56.084,89$ & $3.376,34$ & $-245.143,74$ & $3.048,62$ & $-249.922,31$ \\
5 & 2013 & $-20.250,00$ & $131.323,27$ & $-56.992,58$ & $54.080,69$ & $-191.063,05$ & $44.091,49$ & $-205.830,83$ \\
6 & 2014 & $-49.754,67$ & $135.775,55$ & $-59.956,30$ & $26.064,58$ & $-164.998,47$ & $19.187,55$ & $-186.643,27$ \\
7 & 2015 & $-49.754,67$ & $134.981,17$ & $-57.044,76$ & $28.181,74$ & $-136.816,73$ & $18.732,38$ & $-167.910,90$ \\
8 & 2016 & $-49.754,67$ & $129.145,37$ & $-57.493,19$ & $21.897,51$ & $-114.919,21$ & $13.142,44$ & $-154.768,45$ \\
9 & 2017 & $-49.754,67$ & $129.378,18$ & $-68.292,85$ & $11.330,66$ & $-103.588,56$ & $6.140,34$ & $-148.628,11$ \\
10 & 2018 & $-49.754,67$ & $129.378,18$ & $-57.698,79$ & $21.924,72$ & $-81.663,84$ & $10.728,23$ & $-137.899,88$ \\
11 & 2019 & $-49.754,67$ & $129.378,18$ & $-57.045,19$ & $22.578,32$ & $-59.085,52$ & $9.975,66$ & $-127.924,22$ \\
12 & 2020 & $-49.754,67$ & $129.378,18$ & $-57.698,79$ & $21.924,72$ & $-37.160,80$ & $8.746,62$ & $-119.177,60$ \\
13 & 2021 & $-49.754,67$ & $129.378,18$ & $-57.045,19$ & $22.578,32$ & $-14.582,48$ & $8.133,07$ & $-111.044,53$ \\
14 & 2022 & - & $129.378,18$ & $-57.495,81$ & $71.882,37$ & $57.299,89$ & $23.379,83$ & $-87.664,70$ \\
15 & 2023 & - & $129.378,18$ & $-57.045,19$ & $72.332,99$ & $129.632,89$ & $21.242,79$ & $-66.421,91$ \\
16 & 2024 & - & $129.378,18$ & $-57.698,79$ & $71.679,39$ & $201.312,28$ & $19.007,53$ & $-47.414,38$ \\
17 & 2025 & - & $129.378,18$ & $-68.292,85$ & $61.085,33$ & $262.397,60$ & $14.625,97$ & $-32.788,41$ \\
18 & 2026 & - & $129.378,18$ & $-57.698,79$ & $71.679,39$ & $334.076,99$ & $15.496,67$ & $-17.291,74$ \\
19 & 2027 & - & $129.378,18$ & $-57.045,19$ & $72.332,99$ & $406.409,98$ & $14.120,06$ & $-3.171,68$ \\
20 & 2028 & - & $129.378,18$ & $-57.495,81$ & $71.882,37$ & $478.292,35$ & $12.670,07$ & $9.498,39$ \\
21 & 2029 & - & $129.378,18$ & $-57.045,19$ & $72.332,99$ & $550.625,34$ & $11.511,96$ & $21.010,34$ \\
22 & 2030 & - & $129.378,18$ & $-57.698,79$ & $71.679,39$ & $622.304,73$ & $10.300,62$ & $31.310,96$ \\
23 & 2031 & - & $129.378,18$ & $-57.045,19$ & $72.332,99$ & $694.637,72$ & $9.385,59$ & $40.696,56$ \\
\hline & & & & & & & &
\end{tabular}


conclusão

\begin{tabular}{lllllllll}
\hline \hline 24 & 2032 & - & $129.378,18$ & $-57.495,81$ & $71.882,37$ & $766.520,10$ & $8.421,78$ & $49.118,34$ \\
25 & 2033 & - & $129.378,18$ & $-68.292,85$ & $61.085,33$ & $827.605,42$ & $6.462,12$ & $55.580,45$ \\
26 & 2034 & - & $129.378,18$ & $-57.495,81$ & $71.882,37$ & $899.487,79$ & $6.866,20$ & $62.446,65$ \\
27 & 2035 & - & $129.378,18$ & $-57.045,19$ & $72.332,99$ & $971.820,78$ & $6.238,59$ & $68.685,25$ \\
28 & 2036 & - & $129.378,18$ & $-57.698,79$ & $71.679,39$ & $1.043 .500,17$ & $5.582,14$ & $74.267,39$ \\
29 & 2037 & - & $129.378,18$ & $-57.045,19$ & $72.332,99$ & $1.115 .833,16$ & $5.086,27$ & $79.353,66$ \\
30 & 2038 & - & $129.378,18$ & $-57.698,79$ & $71.679,39$ & $1.187 .512,55$ & $4.551,07$ & $83.904,73$ \\
\hline
\end{tabular}

Nota: Taxa de desconto de 10,75\% ao ano.

${ }^{1}$ Ano do projeto. ${ }^{2}$ Ano calendário. ${ }^{3}$ Entrada e saída de caixa devido à operação de crédito rural. ${ }^{4}$ Receita bruta das vendas. ${ }^{5}$ Desembolsos. ${ }^{6}$ Fluxo de caixa líquido (ESC+RB-D). ${ }^{7}$ Fluxo de caixa líquido acumulado não descontado. ${ }^{8}$ Fluxo de caixa líquido descontado. ${ }^{9}$ Fluxo de caixa líquido acumulado descontado.

Para o cenário 10, o valor para o VPL foi de $\mathrm{R} \$ 861.288,55$ e a TIR apurada foi de $32,29 \%$ ao ano. Verificou-se que o Payback Simples ocorreu no $6^{\circ}$ ano do projeto e o Payback Descontado no $7^{\circ}$ ano do projeto, conforme apresentado na tabela 22.

Tabela 22 - Projeção dos fluxos de caixa do empreendimento com a utilização de recursos próprios, receita bruta auferida a partir da venda de animais e entrada de caixa decorrente do arrendamento da terra, com utilização de média geral dos preços corrigidos - 2009-2038

continua

\begin{tabular}{rrrrrrrrr}
\hline $\mathrm{AP}^{1}$ & $\mathrm{AC}^{2}$ & $\mathrm{EC}^{3}$ & \multicolumn{1}{c}{$\mathrm{RB}^{4}$} & \multicolumn{1}{c}{$\mathrm{D}^{5}$} & \multicolumn{1}{c}{$\mathrm{FCL}$} & $\mathrm{FCL}\left(\mathrm{AND}{ }^{7}\right)$ & \multicolumn{1}{c}{$\mathrm{FCL}\left(\mathrm{D}^{8}\right)$} & $\mathrm{FCL}\left(\mathrm{AD}{ }^{9}\right)$ \\
\hline 1 & 2009 & & & $-12.435,99$ & $-12.435,99$ & $-12.435,99$ & $-15.253,44$ & $-15.253,44$ \\
2 & 2010 & $87.324,38$ & & $-303.794,39$ & $-216.470,01$ & $-228.905,99$ & $-239.740,53$ & $-254.993,97$ \\
3 & 2011 & $87.324,38$ & $12.002,61$ & $-211.653,08$ & $-112.326,09$ & $-341.232,09$ & $-112.326,09$ & $-367.320,06$ \\
4 & 2012 & $87.324,38$ & $71.359,44$ & $-56.084,89$ & $102.598,93$ & $-238.633,15$ & $92.640,12$ & $-274.679,94$ \\
5 & 2013 & $87.324,38$ & $117.563,80$ & $-56.992,58$ & $147.895,60$ & $-90.737,55$ & $120.577,92$ & $-154.102,02$ \\
6 & 2014 & $87.324,38$ & $121.549,59$ & $-59.956,30$ & $148.917,67$ & $58.180,12$ & $109.626,37$ & $-44.475,65$ \\
7 & 2015 & $87.324,38$ & $120.838,44$ & $-57.044,76$ & $151.118,06$ & $209.298,18$ & $100.448,03$ & $55.972,38$ \\
8 & 2016 & $87.324,38$ & $115.614,09$ & $-57.493,19$ & $145.445,28$ & $354.743,47$ & $87.293,31$ & $143.265,69$ \\
9 & 2017 & $87.324,38$ & $115.822,51$ & $-68.292,85$ & $134.854,04$ & $489.597,50$ & $73.080,51$ & $216.346,20$ \\
10 & 2018 & $87.324,38$ & $115.822,51$ & $-57.698,79$ & $145.448,10$ & $635.045,60$ & $71.170,81$ & $287.517,01$ \\
11 & 2019 & $87.324,38$ & $115.822,51$ & $-57.045,19$ & $146.101,70$ & $781.147,30$ & $64.551,36$ & $352.068,37$ \\
12 & 2020 & $87.324,38$ & $115.822,51$ & $-57.698,79$ & $145.448,10$ & $926.595,40$ & $58.024,90$ & $410.093,27$ \\
13 & 2021 & $87.324,38$ & $115.822,51$ & $-57.045,19$ & $146.101,70$ & $1.072 .697,10$ & $52.628,13$ & $462.721,40$ \\
14 & 2022 & $87.324,38$ & $115.822,51$ & $-57.495,81$ & $145.651,08$ & $1.218 .348,18$ & $47.373,19$ & $510.094,59$ \\
15 & 2023 & $87.324,38$ & $115.822,51$ & $-57.045,19$ & $146.101,70$ & $1.364 .449,88$ & $42.907,23$ & $553.001,81$ \\
16 & 2024 & $87.324,38$ & $115.822,51$ & $-57.698,79$ & $145.448,10$ & $1.509 .897,98$ & $38.569,10$ & $591.570,91$ \\
17 & 2025 & $87.324,38$ & $115.822,51$ & $-68.292,85$ & $134.854,04$ & $1.644 .752,02$ & $32.288,78$ & $623.859,70$ \\
18 & 2026 & $87.324,38$ & $115.822,51$ & $-57.698,79$ & $145.448,10$ & $1.790 .200,12$ & $31.445,03$ & $655.304,73$ \\
19 & 2027 & $87.324,38$ & $115.822,51$ & $-57.045,19$ & $146.101,70$ & $1.936 .301,81$ & $28.520,39$ & $683.825,12$ \\
\hline \hline
\end{tabular}


conclusão

\begin{tabular}{lllllllll}
\hline \hline 20 & 2028 & $87.324,38$ & $115.822,51$ & $-57.495,81$ & $145.651,08$ & $2.081 .952,89$ & $25.672,62$ & $709.497,74$ \\
21 & 2029 & $87.324,38$ & $115.822,51$ & $-57.045,19$ & $146.101,70$ & $2.228 .054,59$ & $23.252,41$ & $732.750,15$ \\
22 & 2030 & $87.324,38$ & $115.822,51$ & $-57.698,79$ & $145.448,10$ & $2.373 .502,69$ & $20.901,48$ & $753.651,64$ \\
23 & 2031 & $87.324,38$ & $115.822,51$ & $-57.045,19$ & $146.101,70$ & $2.519 .604,39$ & $18.957,48$ & $772.609,12$ \\
24 & 2032 & $87.324,38$ & $115.822,51$ & $-57.495,81$ & $145.651,08$ & $2.665 .255,47$ & $17.064,57$ & $789.673,68$ \\
25 & 2033 & $87.324,38$ & $115.822,51$ & $-68.292,85$ & $134.854,04$ & $2.800 .109,51$ & $14.265,99$ & $803.939,67$ \\
26 & 2034 & $87.324,38$ & $115.822,51$ & $-57.495,81$ & $145.651,08$ & $2.945 .760,59$ & $13.912,58$ & $817.852,25$ \\
27 & 2035 & $87.324,38$ & $115.822,51$ & $-57.045,19$ & $146.101,70$ & $3.091 .862,29$ & $12.601,02$ & $830.453,27$ \\
28 & 2036 & $87.324,38$ & $115.822,51$ & $-57.698,79$ & $145.448,10$ & $3.237 .310,39$ & $11.326,99$ & $841.780,26$ \\
29 & 2037 & $87.324,38$ & $115.822,51$ & $-57.045,19$ & $146.101,70$ & $3.383 .412,08$ & $10.273,49$ & $852.053,76$ \\
30 & 2038 & $87.324,38$ & $115.822,51$ & $-57.698,79$ & $145.448,10$ & $3.528 .860,18$ & $9.234,79$ & $861.288,55$ \\
\hline
\end{tabular}

Nota: Taxa de desconto de 10,75\% ao ano.

${ }^{1}$ Ano do projeto. ${ }^{2}$ Ano calendário. ${ }^{3}$ Entrada de caixa devido ao arrendamento da terra. ${ }^{4}$ Receita bruta das vendas. ${ }^{5}$ Desembolsos. ${ }^{6}$ Fluxo de caixa líquido (ESC+RB-D). ${ }^{7}$ Fluxo de caixa líquido acumulado não descontado. ${ }^{8}$ Fluxo de caixa líquido descontado. ${ }^{9}$ Fluxo de caixa líquido acumulado descontado. 
Para nortear a discussão e a compreensão das relações de causa e efeito nos índices obtidos, é necessário firmar que, os resultados foram gerados a partir de duas variáveis: níveis de preços da arroba da carne e utilização de financiamento.

A tabela 23 resume os resultados obtidos para facilitar a visualização e análise conjunta dos resultados para os cenários propostos:

Tabela 23 - Determinação da viabilidade econômica do empreendimento, a partir das diferentes técnicas de análise para os diferentes cenários propostos.

\begin{tabular}{cccccc}
\hline Cenário & $\begin{array}{c}\text { Ano Payback } \\
\text { Simples }\end{array}$ & $\begin{array}{c}\text { Ano Payback } \\
\text { Descontado }\end{array}$ & $\begin{array}{c}\text { VPL } \\
(\mathrm{i}=10,75 \%)\end{array}$ & TIR & TIRM $^{1}$ \\
\hline 1 & $18^{\circ}$ & $\ldots$ & $-234.839,89$ & 4,74 &.. \\
2 & $23^{\circ}$ & $\ldots$ & $-167.809,35$ & $3,61 ?$ & 7,11 \\
3 & $23^{\circ}$ & $\ldots$ & $-177.258,23$ & $3,82 ?$ & 7,50 \\
4 & $13^{\circ}$ & $\ldots$ & $-83.491,57$ & 8,95 &.. \\
5 & $16^{\circ}$ & $\ldots$ & $-7.461,02$ & $10,45 ?$ & 10,62 \\
6 & $16^{\circ}$ & $\ldots$ & $-16.909,91$ & $10,14 ?$ & 10,42 \\
7 & $11^{\circ}$ & $27^{\circ}$ & $17.323,07$ & 11,10 &.. \\
8 & $14^{\circ}$ & $19^{\circ}$ & $93.353,61$ & 14,35 &.. \\
9 & $14^{\circ}$ & $20^{\circ}$ & $83.904,73$ & 13,65 &.. \\
10 & $6^{\circ}$ & $7^{\circ}$ & $861.288,55$ & 32,29 &.. \\
\hline
\end{tabular}

Nota: Sinais convencionais utilizados:

... Dado numérico não disponível.

? Dúvida quanto à exatidão do valor dado.

.. Não se aplica dado numérico.

${ }^{1}$ Metodologia proposta por Lin (1976 apud BARBIERI, 2007, p 137).

Para a variação nos preços da arroba utilizou-se três níveis, o mínimo, o médio e o máximo. Deve-se ressaltar que os cenários nos quais foi utilizado o nível médio de preços (4, 5 e 6$)$ da arroba são os mais realistas. Nos cenários nos quais foi utilizado o nível mínimo de preços (1, 2 e 3) procurou-se representar situações em que os preços relativos dos fatores de produção subiriam mais que 
proporcionalmente aos preços da carne ${ }^{48}$. Nos cenários de nível máximo de preços (7, 8 e 9), procuro-se a representação extrema e contrária à situação apresentada nos cenários de nível mínimo de preços.

Para a utilização de financiamento utilizou-se duas situações para pagamento das parcelas devidas. Onde parcela e tempo de carência se diferenciam.

A utilização de financiamento impactou sobremaneira os resultados obtidos para os cenários de nível médio de preços (4, 5 e 6) e criou uma situação crítica para a aceitação ou não do projeto. Se utilizados os critérios de decisão para aceitar/rejeitar o projeto, conforme preconizaram Bordeaux-Rego et al., (2006); Gitman, (1997) e Shinoda, (2008), o empreendimento não seria viável economicamente. Porém notou-se que o VPL e a TIR para os cenários 5 e 6 , nos quais utilizou-se o financiamento, aproximou-se dos limites para os critérios de aceitação. Nessa situação o Payback Simples, embora considerado uma técnica limitada, apresenta-se importante. Nota-se que nessa situação o número de períodos (16 anos) - Payback Simples - pode sinalizar como uma medida de risco associada ao tempo de retorno (BALARINE, 2004; BORDEAUX-REGO et al., 2006; GITMAN, 1997; SAMPAIO FILHO, 2008; SHINODA, 2008).

Todos os cenários nos quais se utilizou o nível mínimo de preços implicam na não aceitação do projeto. Embora represente uma situação extrema - que provavelmente não seja verificada na prática - sinaliza uma tendência típica dos mercados de produtos agropecuários, nos quais ocorre uma deterioração nos termos de troca para alguns insumos de produção, conforme observado em Paniago (2002). Outra situação seria a da baixa eficiência na utilização das tecnologias de produção, situação na qual elevaria os custos de produção em detrimento às receitas, observado por Rodrigues et al. (2010).

Para os cenários nos quais foram utilizados níveis máximos de preços, todos os critérios abalizaram para a aceitação do projeto. Observou-se, para o cenário 7, níveis críticos (Payback Simples, Payback Descontado, VPL e TIR) em relação aos critérios de aceitação/rejeição. Situação que tende a melhorar para os cenários 8 e 9, mas ainda assim levando o retorno do investimento para o terço

\footnotetext{
${ }^{48}$ PANIAGO, R. (Org.). Intensificação da pecuária de corte no Brasil. Piracicaba: Boviplan Consultoria Agropecuária. 2002. 165 p.
} 
final do horizonte de análise e podendo tornar, na ótica do investidor, a execução do empreendimento arriscada economicamente.

Em todos os cenários analisados, notou-se melhoria nos resultados quando da utilização de financiamento. Esta melhoria deveu-se ao fato de que o custo do capital, ou taxa de empréstimo contratada, ter sido menor que a TMA (taxa de desconto) utilizada na obtenção dos índices de viabilidade econômica, a saber: $6,75 \%$ e 10,75\% respectivamente. Outrossim, a entrada de capital saneou os fluxos líquidos de caixa e consequentemente provocou melhora nos índices de viabilidade econômica. Ressalta-se oportunamente a importância dos prazos de carência mais dilatados quando dos pagamentos das parcelas de juros oriundas das obrigações relacionadas à opção de financiamento.

O cenário 10 justifica a produção sob alta lotação. Apresentou-se como um dos principais motivadores - se não o principal - da utilização do sistema sob alta lotação na pecuária comercial. Proporcionou a possibilidade do uso intensivo da terra e retornos econômicos expressivos da condição de arrendamento da área a ser liberada. Explicitou o alto custo de oportunidade da terra, conforme observaram Füsternau (2004) e Bierhals e Ferraz (2008) e demonstrado na tabela 5 (IBGE, 2010).

Uma recomendação importante é execução da análise econômica, com a apreciação conjunta dos indicadores de viabilidade. Desta forma pode-se embasar melhor a decisão, no caso da aplicação comercial.

O aspecto central para a consideração dos resultados obtidos neste trabalho é que esses são particulares para a infraestrutura considerada, que priorizou a execução de pesquisas.

$\mathrm{Na}$ ótica das instituições sem fins lucrativos, como no caso da Universidade de São Paulo, observou-se a possibilidade da obtenção de resultado que recupere os custos implícitos e explícitos do capital consumido pelos projetos de pesquisa. Esta premissa auxilia a transferência de tecnologias geradas na pesquisa - quando da atividade de extensão - pois subsidia o extensionista de argumentos frente aos produtores que desenvolvem a atividade pecuária com fins lucrativos.

O estudo de viabilidade é o conjunto de informações que antecede à execução de um projeto e tem por objetivo auxiliar o processo de tomada de 
decisão para um empreendimento. A análise econômica é parte integrante deste estudo. Não constitui garantia de sucesso, porém pode representar menores possibilidades de fracasso, tanto na ótica da produção quanto na decisão do investimento. 


\section{CONCLUSÃO}

O sistema de produção de pecuária de bovinos de corte - sob alta lotação animal e com ciclo completo de produção - proposto para a implantação de pesquisas zootécnicas foi viável economicamente - sob a ótica comercial estritamente para os cenários que consideraram o nível máximo de projeção de preços da arroba da carne (7, 8 e 9) e para o cenário 10 quando adotados os critérios técnicos de aceitação/rejeição de projetos de investimento. A utilização de financiamento via Programa de Crédito Rural do BNDES proporcionou melhora expressiva nos valores monetários e índices utilizados na análise. 


\section{REFERÊNCIAS}

ASSOCIAÇÃO BRASILEIRA DAS INDÚSTRIAS EXPORTADORAS DE CARNE ABIEC. Disponível em: <http://www.abiec.com.br/2_mapa.asp>. Acesso em: 3 jun 2010.

ABREU, U. G. P.; CEZAR, I. M.; TORRES, R. A. Análise bioeconômica da introdução de período de monta em sistemas de produção de rebanhos de cria na região do Brasil central. Revista Brasileira de Zootecnia, v. 32, n. 5, p.1198-1206, 2003.

AKALU, M. M. Re-examining project appraisal and control: developing a focus on wealth creation. International Project Management, n. 19, p. 375-383, 2001.

AFONSO, E. Criação de bovinos de corte na região sudeste. Sistemas de produção CNPTIA EMBRAPA, 2003. Disponível em:

<http://sistemasdeproducao.cnptia.embrapa.br/FontesHTML/BovinoCorte/BovinoCort eRegiaoSudeste/saude.htm>. Acesso em: 13 ago. 2010.

ANUÁRIO DA PECUÁRIA BRASILEIRA - ANUALPEC 2008, São Paulo: IFNP, 2009. $380 \mathrm{p}$.

BALARINE, O. F. O. Contribuições metodológicas ao estudo de viabilidade econômico-financeira das incorporações imobiliárias. In: FORMOSO, C. (Ed.). Métodos e ferramentas para a gestão da qualidade e produtividade na construção civil. Porto Alegre, UFRGS-NORIE/PQPCCRS, 1997. p. 11-28.

BALARINE, O. F. O. O uso da análise de investimentos em incorporações imobiliárias. Revista Produção, v. 14, n. 2, p. 47-57. 2004.

BANCO NACIONAL DE DESENVOLVIMENTO ECONÔMICO E SOCIAL - BNDES. Programas Agropecuários. Disponível em:

<http://www.bndes.gov.br/SiteBNDES/bndes/bndes_pt/Institucional/Apoio_Financeiro /Programas_e_Fundos/Agropecuarios/index.html>. Aceso em: 7 set. 2010.

BARBIERI, J.; ÁLVARES, A.; MACHLINE, C. Taxa Interna de Retorno: controvérsias e interpretações. GEPROS. Gestão da Produção, Operações e Sistemas, v. 5, n. 4, out/dez 2007, p. 131-142. 
BERETTA, V.; LOBATO, J. F. P.; NETTO, C. G. M. Produtividade e eficiência biológica de sistemas de produção de gado de corte de ciclo completo no Rio Grande de Sul. Revista Brasileira de Zootecnia, v. 31, n. 2, p. 991-1001, 2002 (suplemento).

BERNARDI, A. C. de C.; ESTEVES, S. N; BARBOSA P. F.; VINHOLIS, M. de M. B. Renovação de pastagem e terminação de bovinos em sistema de integração lavoura pecuária em São Carlos, SP: resultados de 3 anos de avaliações. São Carlos, SP: Embrapa Pecuária Sudeste, Documento 24, 2009. 28p.

BIERHALS, J. D.; FERRAZ, J. V. O pasto perde espaço para a lavoura. Anuário estatístico da produção animal, São Paulo, p. 34-40, 2008.

BORDEAUX-RÊGO, R.; GORET, P. P.; SPRITZER, I. M. P. A.; ZOTES, L. P. Viabilidade econômico-financeira de projetos. Rio de Janeiro: FGV, 2006. 164 p.

BRASIL. Ministério da Agricultura, Pecuária e Abastecimento. Secretaria de Política Agrícola. Instituto Interamericano de Cooperação para a Agricultura - IICA. Cadeia produtiva da carne bovina. Brasília: IICA: MAPA/SPA, 2007. 86 p.

(Agronegócios,8).

BRITO, P. Análise e viabilidade de projetos de investimento. 2. ed. São Paulo: Atlas, 2006. $100 \mathrm{p}$.

BUARQUE, C. Avaliação econômica de projetos. Rio de Janeiro: Campus, 1991. $266 \mathrm{p}$.

BUFON, A. G. M.; TAUCK-TORNISIELO, S. M.; LAURINDO JUNIOR, V.; MARAMARQUE, J. R. Índices de pluviosidade em duas microbacias do rio MogiGuaçu, Estado de São Paulo, Brasil. Holos Environment, v. 4, p. 14-22, 2004.

CADIAN. Intellicad Cadian 2008i Professional Plus. Belo Horizonte, 2010. Disponível em: <http://www.intellicadian.com.br/IntelliCAD/Loja.aspx>. Acesso em: 19 abr. 2010.

CANZIANI, M. F.; REIS, R. P.; DOSSA, D. Gestão empresarial da bovinocultura de corte: desenvolvimento de um instrumento de controle gerencial. In: CONGRESSO BRASILEIRO DE ECONOMIA E SOCIOLOGIA RURAL, 36., 1998, PoçOs de Caldas. Anais... Brasília: Sober, 1998, v. 1, p. 273-286. 
CARVALHO, M. L. de; LIMA, I. B. de; CRUZ, F. O. O desenvolvimento do agronegócio da carne bovina no Brasil no período 1994-2006. Sociedade Brasileira de Economia, Administração e Sociologia Rural - SOBER, [2007]. Disponível em: <http://www.sober.org.br/palestra/6/469.pdf> Acesso em: 19 jan. 2010.

CASAROTTO FILHO, N. Elaboração de projetos empresariais: análise estratégica, estudo de viabilidade e plano de negócios. São Paulo: Atlas, 2009. p. 248.

CENTRO DE ESTUDOS E PESQUISA AVANÇADOS EM ECONOMIA APLICADA CEPEA. Áreas de pesquisa. Disponível em:<http://www.cepea.esalq.usp.br/boi/?merc=2>. Acesso em: 6 jun. 2010.

CEZAR, I. M. Racionalização de investimentos em pastagens: uma abordagem sistêmica no processo decisório, [2001]. Disponível em:<http://www.cnpgc.embrapa.br/ ivocezar/piracicaba/index.html> Acesso em: 14 jan. 2010.

CEZAR, I. M.; QUEIROZ, H. P.; THIAGO, L. R. L. S.; CASSALES, F. L. G.; COSTA, F. P. Sistemas de produção de gado de corte no Brasil: uma descrição com ênfase no regime alimentar e no abate. Campo Grande, MS: Embrapa Gado de Corte, 2005. 40 p. (Documento 151).

CLEMENTE, A. (Org.). Projetos empresariais e públicos. São Paulo: Atlas, 1998. $341 \mathrm{p}$.

COAN, R. M.; REIS, R. A.; RESENDE, F. D.; SAMPAIO, R. L.; SCHOCKENITURRINO, R. P.; GARCIA, G. R.; BERCHIELLI, T. T.; Viabilidade econômica, desempenho e características de carcaça de garrotes em confinamento alimentados com dietas contendo silagem de capins tanzânia ou marandu ou silagem de milho. Revista Brasileira de Zootecnia, v. 37, n. 2, p. 311-318, 2008.

COHEN, D. J.; GRAHAN R. J. Gestão de projetos: MBA executivo. (Trad.) Afonso Celso da Cunha Serra. São Paulo: Campus, 2002. 305 p.

COORDENADORIA DE DEFESA AGROPECUÁRIA - CDA. Sanidade animal.Disponível em:

$<$ http://www.cda.sp.gov.br/www/programas/index.php?action=list\&cod=1\&nm=Sanid ade Animal>. Acesso em: 16 ago. 2010. 
CORREAA, E. S.; VIEIRA, A.; COSTA, F. P.; CEZAR, I. M. Sistema semi-intensivo de produção de carnes de bovinos nelores no Centro-Oeste do Brasil. Campo Grande, MS, Embrapa Gado de Corte, 2000., 49 p.(Documento 95). CRISTHOFARI, L. F. Análise da comercialização de bezerros de corte no Rio Grande do Sul. 2007. 144 f. Tese (Doutorado em Zootecnia) - Faculdade de Agronomia, Universidade Federal do Rio Grande do Sul, Porto Alegre, 2007.

DIAS, J. A.; MÜLLER, E. E.; DIAS, R. A.; FREITAS, J. C.; AMAKU, M.; FERREIRA, F.; SILVA, M. C. P.; LÔBO, J. R.; FIGUEIREDO, V. C. F.; GONÇALVES, F. S. P.; FERREIRA NETO, J. S. Situação epidemiológica da brucelose bovina no Estado do Paraná. Arquivo Brasileiro de Medicina Veterinária Zootecnia. 2009, v.61, p. 6676. (suplemento 1).

EMPRESA BRASILEIRA DE PESQUISA AGROPECUÁRIA - EMBRAPA. Sistema Brasileiro de Classificação de Solos. Disponível em:

$<$ http://www.cnps.embrapa.br/sibcs/>. Acesso em: 4 abr. 2010.

EUCLIDES FILHO, K. Produção de bovinos de corte e o trinômio genótipoambiente-mercado. Campo Grande, MS: Embrapa Gado de Corte, 2000., 61 p. (Documento 85).

EUCLIDES, V. P. B.; EUCLIDES FILHO, K.; ARRUDA, Z. J. de; FIGUEIREDO, G. R. Desempenho de novilhos em pastagens de Brachiaria decumbens submetidos a diferentes regimes alimentares. Revista Brasileira de Zootecnia, v. 27, n. 2, p. 246254, 1998.

FOOD AND AGRICULTURE ORGANIZATION OF THE UNITED NATIONS - FAO. Statistics. In.: ProdSTAT: FAOSTAT. Disponível em: <http://faostat.fao.org/site/573/DesktopDefault.aspx?PagelD=573\#ancor> Acesso em: 11 fev. 2010.

FIGUEIREDO, D. M. de; OLIVEIRA, A. S de; SALES, M. F. L.; PAULINO, M. F.; VALE, S. M. L. R. do. Análise econômica de quatro estratégias de suplementação para recria e engorda de bovinos em sistema pasto-suplemento. Revista Brasileira de Zootecnia, v. 36, n. 5, p. 1443-1453, 2007.

FÜRSTENAU, V. Pecuária de corte: baixos índices zootécnicos e eficiência no setor exportador. Indicadores Econômicos FEE, Porto Alegre, v. 32, n. 1, p. 265-292, 2004.

FUNDAÇÃO GETÚLIO VARGAS. IGP-DI índice geral de preços. Disponível em: $<$ http://www.ibre.fgv.br/>. Acesso em: 22 jun. 2010. 
GAMEIRO, A. H. Análise econômica aplicada à zootecnia: avanços e desafios. In: SIMPÓSIO DE PÓS-GRADUAÇÃO E PESQUISA DO DEPARTAMENTO DE NUTRIÇÃO E PRODUÇÃO ANIMAL, 3., 2009, Pirassununga. Anais...

Pirassununga, 2009. (CD-ROM).

GITMAN, L. J. Princípios da administração financeira. São Paulo: Harbra, 1997. $841 \mathrm{p}$.

GONÇALVES, C. C. M.; TEIXEIRA, J. C.; OLALQUIAGA PÉREZ, J. R.

Desempenho de bovinos de corte a pasto suplementados com uréia e amiréia $150 S$ no período seco. In: REUNIÃO ANUAL DA SOCIEDADE BRASILEIRA DE ZOOTECNIA, 40, 2003, Santa Maria, RS. Anais... Santa Maria: SBZ, 2003.

GOOGLE. Google earth . Disponível em:

<http://www.apolo11.com/satmap2_cidades.php?citynum=5167>. Acesso em: 1 abr. 2010.

HISRSHFELD, H. Viabilidade técnico-econômica de empreendimentos. São Paulo: Atlas, 1993. 211 p.

HOJI, M. Administração financeira: uma abordagem prática. 5 ed. São Paulo: Atlas, 2004. 525 p.

INSTITUTO BRASILEIRO DE GEOGRAFIA ESTATÍSTICA - IBGE. Pesquisa Pecuária Municipal. Disponível em: <http://www.ibge.gov.br>. Acesso em: 25 jan. 2010a.

INSTITUTO BRASILEIRO DE GEOGRAFIA ESTATÍSTICA - IBGE. Cidades. Disponível em:<http://www.ibge.gov.br/cidadesat/topwindow.htm?1>. Acesso em: 15 jun. 2010b.

ICHIHARA, S. M.; Desmatamento e recuperação de pastagens degradadas na região amazônica: uma abordagem através das análises de projetos. 2003. 106 f. Dissertação (Mestrado em Ciências) - Escola Superior de Agricultura "Luiz de Queiroz", Universidade de São Paulo, Piracicaba. 2003.

IGREJA, A. C. M.; CAMPOS, B. E. S.; ROCHA, M. B; PINATTI, E.; MARTINS, S. S.; BLISKA, F. M. M. Os novos desafios da cadeia produtiva da carne frente à crise econômica. Análise e Indicadores do Agronegócio, v. 4, n. 9, 2009. 
JONES, A. M. Serviços de engenharia. 2ed. Rio de Janeiro: LTC, 1990.

JORGE JÚNIOR, J.; CARDOSO, V. L.; ALBUQUERQUE. L. G. Modelo bioeconômico para cálculo de custos e receitas em sistemas de produção de gado de corte visando à obtenção de valores econômicos de características produtivas e reprodutivas. Revista Brasileira de Zootecnia, v. 35, n. 5, p. 2187-2196, 2006.

KEYNES. J. M. A Teoria geral do juro, da moeda e do emprego. São Paulo: Abril Cultural, 1988. $164 \mathrm{p}$.

KÖPPEN, W. 1948. Climatologia: con un estudio de los climas de la tierra. Fondo de Cultura Econômica. México. 479 p.

LEFLEY, F. Accounting rate of return: back to basics. Management Accounting; mar.1998, 76.3.ABI/INFORM Global. p.52-53.

LIN, S. A. The modified internal rate of return and investment criterion. The Engineering Economist, v.21, Summer, p. 237-247, 1976.

LOPES, A. B.; MARTINS, E. Teoria da contabilidade : Uma nova abordagem. São Paulo: Atlas, 2005. 184 p.

LORENZETTI, L; SILVA, M. J. da; D'OLIVEIRA, S. P. Viabilidade econômica da bovinocultura de corte em pastejo rotacionado ou extensivo. Revista em Agronegócios e Meio Ambiente, v. 1, n. 1, p. 45-54, jan/abril. 2008.

LUSTOSA, P. R. B.; SANTOS, A. Proposta de integração plena do balanço e da demonstração do resultado com a demonstração dos fluxos de caixa por atividades: teoria e exemplos práticos. In: ENCONTRO NACIONAL DOS PROGRAMAS DE PÓS-GRADUAÇÃO EM ADMINISTRAÇÃO - EMPAD 29, 2005, Brasília. Anais... Brasília: ANPAD, 2005, CD-ROM.

MARION, J. C. Contabilidade da pecuária. 8 ed. São Paulo: Atlas, 2007. 216 p.

MARQUES, P. V.; PERINA, R. A. Estudo comparativo de viabilidade econômica das atividades de pecuária de corte e das culturas de laranja e cana-de-açúcar. Disponível em: <http://www.pecege.esalq.usp.br/site/upload/8.pdf>Acesso em: 27 jul. 2010. 
MAXIMIANO, A. C. A. Administração de Projetos: como transformar idéias em resultados. 2. ed. São Paulo: Atlas, 2002. 281 p.

MAYA, F. L. A. Produtividade e viabilidade econômica da recria e engorda de bovinos em pastagens adubadas intensivamente com e sem o uso da irrigação. 2003. 82 f. Dissertação. (Mestrado em Agronomia), Escola Superior de Agricultura "Luiz de Queiroz", Universidade de São Paulo, Piracicaba. 2003.

MEIRELLES, J. L. F. A teoria de opções reais como instrumento de avaliação de projetos de investimento. 2004.117 f. Dissertação (Mestrado em Engenharia) Escola de Engenharia de São Carlos, São Carlos. 2004.

MELNICK, J. Manual de projetos de desenvolvimento econômico. Rio de Janeiro: Unilivros Cultural, 1981.

MENDONÇA, M. M. F. Gestão da Qualidade. Rio de Janeiro: Fundação Getulio Vargas, 2001. 77 p. Apostila.

METRICA TECNOLOGIA. Topo EVN 6. Piracicaba, 2010. Disponível em: <http://www.metrica.com.br/>. Acesso em: 21 abr. 2010.

MICROSOFT CORPORATION. Microsoft $®$ Office Excel®. São Paulo, 2008. Disponível em: <http://office.microsoft.com/pt-br/>. Acesso em 06 out. 2010.

NUNES, R.; FORMIGONI, I. B.; BRUMATTI, R. C. As relações entre os segmentos de cria e engorda na era do real. In: CONGRESSO INTERNACIONAL DE ECONOMIA E GESTÃO, 3 ed. 2001, Ribeirão Preto. Anais... Ribeirão Preto, 2001. (CD-ROM).

OAIGEN, R. P.; BARCELLOS, J. O. J.; CHRISTOFARI, L. F.; BRACCINI NETO, J.; OLIVEIRA, T. M. de; PRATES, E. R. Análise da sensibilidade da metodologia dos centros de custos mediante a introdução de tecnologias em um sistema de produção de cria. Revista Brasileira de Zootecnia, v. 38, n. 6, p. 1155-1162, 2009.

PANIAGO, R. (Org.). Intensificação da pecuária de corte no Brasil. Piracicaba: Boviplan Consultoria Agropecuária. 2002. 165 p.

PARKER, R. H. Discounted cash flow in historical perspective. Journal of Accounting Research, v. 6, n. 1, 1968. p. 58-71. 
PERES, A. A. C.; SOUZA, P. M de; MALDONADO, H.; SILVA, J. F. C. da; SOARES, C. S.; BARROS, S. C. W.; HADDADE, I. R. Análise Econômica de Sistemas de Produção a Pasto para Bovinos no Município de Campos dos Goytacazes - RJ. Revista Brasileira de Zootecnia, v. 33, n. 6, p. 1557-1563, 2004.

PFIZER, INCORPORATED. Disponível em:

<http://www.pfizersaudeanimal.com.br/homeBovinos.asp> Acesso em: 13 ago. 2010.

PINATTI, E. Produtividade da bovinocultura de corte paulista em 2005. Informações Econômicas, São Paulo, v. 37, n. 6, p. 17-25, jun. 2007.

RODRIGUES, R.; GAMEIRO, A. H.; ALVES, A. C.; ALVES, T. C. Classificação dos sistemas de produção da pecuária de corte: propondo uma revisão com base em eficiência e tecnologia. REUNIÃO ANUAL DA SOCIEDADE BRASILEIRA DE ZOOTECNIA, 47.2010, Salvador. Anais... Salvador:SBZ, 2010.

SAMPAIO FILHO, A. C. de S. Taxa interna de retorno modificada: proposta de implementação automatizada para cálculo em projetos não-periódicos, não necessariamente convencionais. 2008. 143 f. Dissertação (Mestrado em Administração) - Faculdade de Economia e Finanças - IBMEC, Rio de Janeiro, 2008.

SANDRONI, P., Dicionário de economia. 5 ed. São Paulo: Editora Best Seller. 2000. $300 \mathrm{p}$.

SHINODA, C. Viabilidade de projetos de investimentos em equipamentos com tecnologia avançada de manufatura: Estudo de múltiplos casos na siderurgia brasileira. 2008. 176 f. Tese (Doutorado em Engenharia) - Escola Politécnica da Universidade de São Paulo, São Paulo. 2008.

SLACK, N.; CHAMBERS, S.; HARLAND, C.; HARRISSON, A.; JOHNSTON, R. Administração da produção. (Rev.) Henrique Corrêa, Irineu Gianesi. São Paulo: Atlas, 1999. 526 p.

SOUZA, A. B. Projetos de investimento de capital: elaboração, análise, tomada de decisão. São Paulo: Atlas, 2003. 216 p.

SOUZA, M. S. de. Fluxo de caixa por regime de competência. 2006. 93 f. Dissertação (Mestrado em Ciências Contábeis) - Escola de Administração e Contabilidade, Universidade de São Paulo, São Paulo, 2006. 
TORRES, A de M.; TONINI, M, G, O. Confinamento: gestão técnica e econômica. In: ENCONTRO DE CONFINAMENTO, 4, 2009, Jaboticabal. Anais... Jaboticabal, 2009.

VIANA, J. G. A.; SOUZA, R. S. de; SILVEIRA, V. C. P. Evolução dos preços históricos da bovinocultura de corte do Rio Grande do Sul: Tendência e comportamento dos preços em nível de produtor e consumidor. Ciência agrotecnologia., Lavras, v. 33, n. 4, p. 1109-1117, jul/ago. 2009.

VIDEIRA, C. D. B. Instalações em bovinos de corte. Disponível em: <http://www.bu.ufsc.br/cac/ApostilasCac.html> Acesso em: 26 jun. 2010.

VITTI, G. C.; QUEIROZ, F. E. C.; OTTO, R.; QUINTINO, T. A. Nutrição e adubação da cana-de-açucar, [2005]. Disponível em:

<http://www.agencia.cnptia.embrapa.br/Repositorio/Nutricao+cana+GVitti_000fh3r3v zp02wyiv80rn0etnmc6zamd.pdf> Acesso em: 12 ago. 2010.

WOILER, S.; MATHIAS, W. F. Projetos: planejamento, elaboração e análise. 2 ed. São Paulo: Atlas, 2008. 288 p.

ZILIO, L. B.; MANSUR, P. T. B; CUNHA-FILHO, H.; MARTINES FILHO, J. G. O comportamento da base dos contratos futuros de boi gordo em Minas Gerais, Mato Grosso do Sul, Paraná e São Paulo na BM\&F e CME. [2007]. Disponível em: <http://www.sober.org.br/palestra/6/851.pdf> Acesso em: 14 jul. 2010. 


\section{APÊNDICES}

APÊNDICE A - Definição dos objetivos do empreendimento

O ponto de partida para o planejamento do empreendimento tratou da definição dos objetivos do projeto. Especificamente para o empreendimento ${ }^{49} \mathrm{em}$ questão, o produto do projeto pretendeu atender uma necessidade do Laboratório de Pesquisa em Gado de Corte (LPGC), do Departamento de Nutrição e Produção Animal (VNP), da Faculdade de Medicina Veterinária e Zootecnia (FMVZ) da Universidade de São Paulo (USP).

Os diferentes níveis de realização dos objetivos e seu encadeamento foram:

I. Produto ou resultado do projeto: Implantação do Laboratório de Pesquisas em Bovinos de Corte.

II. Objetivo imediato: Implantação de infraestrutura para a produção de bovinos de corte, de modo a possibilitar a realização de experimentos de desempenho individual e coletivo de bovinos destinados ao corte.

III. Objetivo final: O VNP conta atualmente com os laboratórios de: (i) Bromatologia; (ii) Tecnologia de Alimentos de Origem Animal; (iii) Pesquisa em Bovinos de Leite; (iv) Metabolismo de Ruminantes e (v) Genômica Funcional. Conjuntamente com as atividades desenvolvidas nos laboratórios existentes, o sistema de produção - Laboratório de Pesquisa em Bovinos de Corte - viabilizará a realização das seguintes atividades, entre outras: (i) Avaliação de dietas e aditivos sobre o desempenho e eficiência animal; (ii) Determinação da eficiência individual de crescimento; (iii) Teste de fármacos e hormônios sobre o desempenho produtivo, reprodutivo e sanitário de bovinos; (iv) Comparação entre raças e linhagens; (v) Elaboração de análises econômicas na produção de ruminantes; (vi) Desenvolvimento de

\footnotetext{
${ }^{49}$ Proposto e idealizado pelo profo Dr. Luis Felipe Prada e Silva, responsável pela área de produção de bovinos de corte do VNP/FMVZ/USP.
} 
metodologias de avaliação do bem-estar animal; (vii) Desenvolvimento, promoção e aplicação de tecnologias desenvolvidas, por parte de produtores e pela indústria frigorífica. 
APÊNDICE B - Infraestrutura do empreendimento

A definição da infraestrutura do empreendimento englobou: (i) a descrição da localização do empreendimento; (ii) o levantamento topográfico e cadastral da gleba; (iii) a definição do layout; (iv) o levantamento pedológico e climático; (v) o estabelecimento da cultura de cana de açúcar; (vi) o estabelecimento das pastagens; (vii) a sistematização da área destinada às instalações e edificações do confinamento de animais; e (viii) das execução dos projetos de engenharia.

(i) Localização do empreendimento

A infraestrutura foi projetada para implantação na área experimental do Laboratório de Pesquisa em Gado de Corte (LPGC) do Departamento de Nutrição e Produção Animal (VNP) no Campus da Universidade de São Paulo (USP), situado em Pirassununga - SP. A gleba está situada nas coordenadas geográficas: latitude Sul $21^{\circ} 94^{\prime}$, longitude Oeste $47^{\circ} 45^{\prime}$, a $627 \mathrm{~m}$ de altitude (Figura 12).

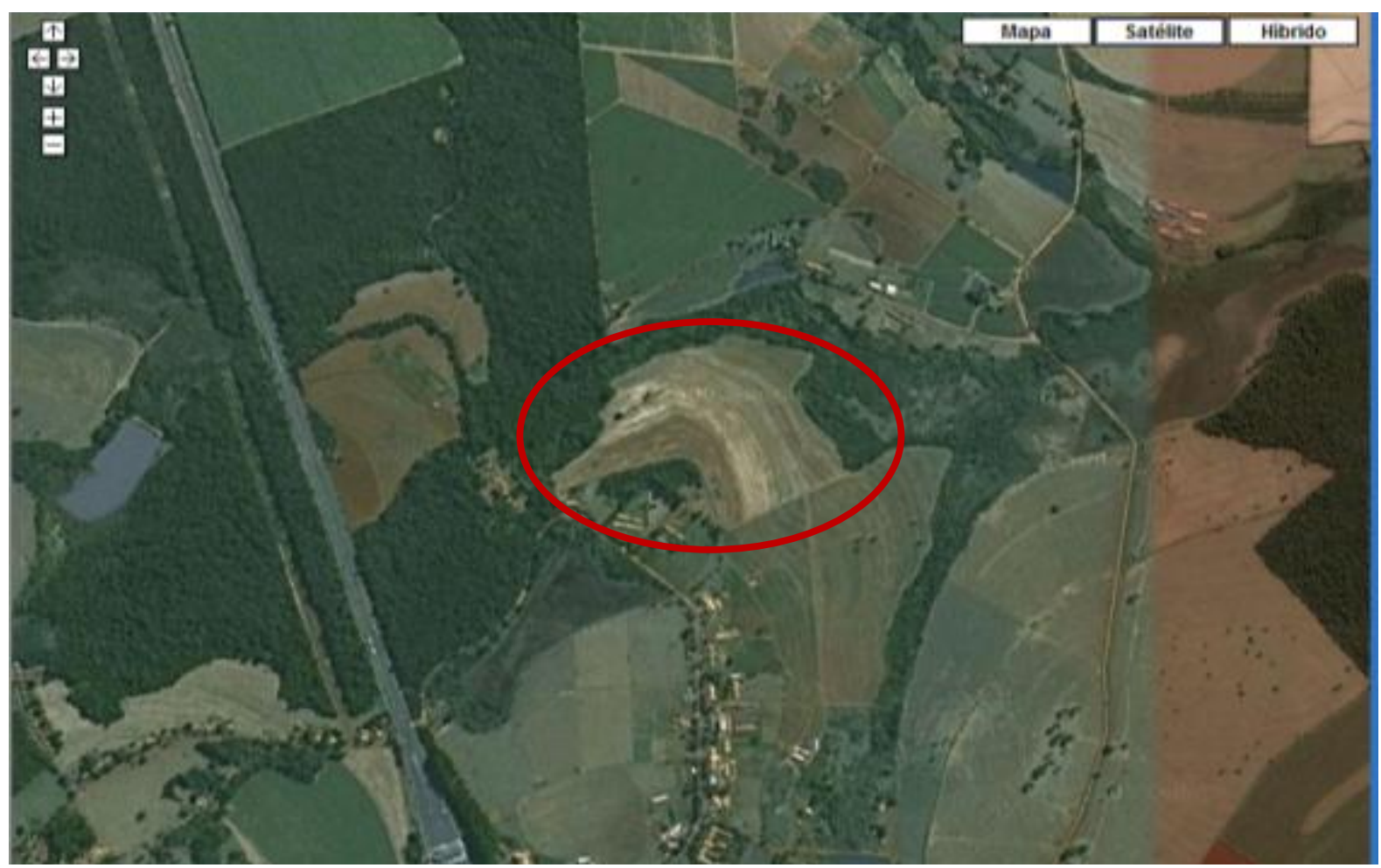

Fonte: Google (2010).

Figura 12 - Localização da gleba 
O município de Pirassununga está localizado a uma latitude 21059' Sul e a uma longitude $47^{\circ} 25^{\prime}$ Oeste, altitude de 627 metros e possui uma área de 727 km². Os municípios limítrofes de Pirassununga são: Descalvado, Porto Ferreira, Santa Cruz das Palmeiras, Analândia, Mogi Guaçu, Aguaí, Leme e Santa Cruz da Conceição. O município é atendido pelas rodovias SP 225, SP 328 e SP 330 (IBGE, 2010b).

(ii) Levantamento topográfico e cadastral das glebas

Para o início das atividades e em decorrência da alta infestação de invasoras no local, executou-se no mês de novembro de 2009, uma operação de preparo do solo - gradagem - com o intuito de: demarcar a área; promover a decomposição da matéria verde e facilitar das atividades da equipe de topografia (Figura 13).



Fonte: Maccann Engenharia SS Ltda.

Figura 13 - Aspecto geral da área do empreendimento

Para a execução da operação foi utilizado um trator de pneus de 180 cv e grade aradora controle remoto com discos - 16 x 32" - côncavos recortados (Figura 14). 


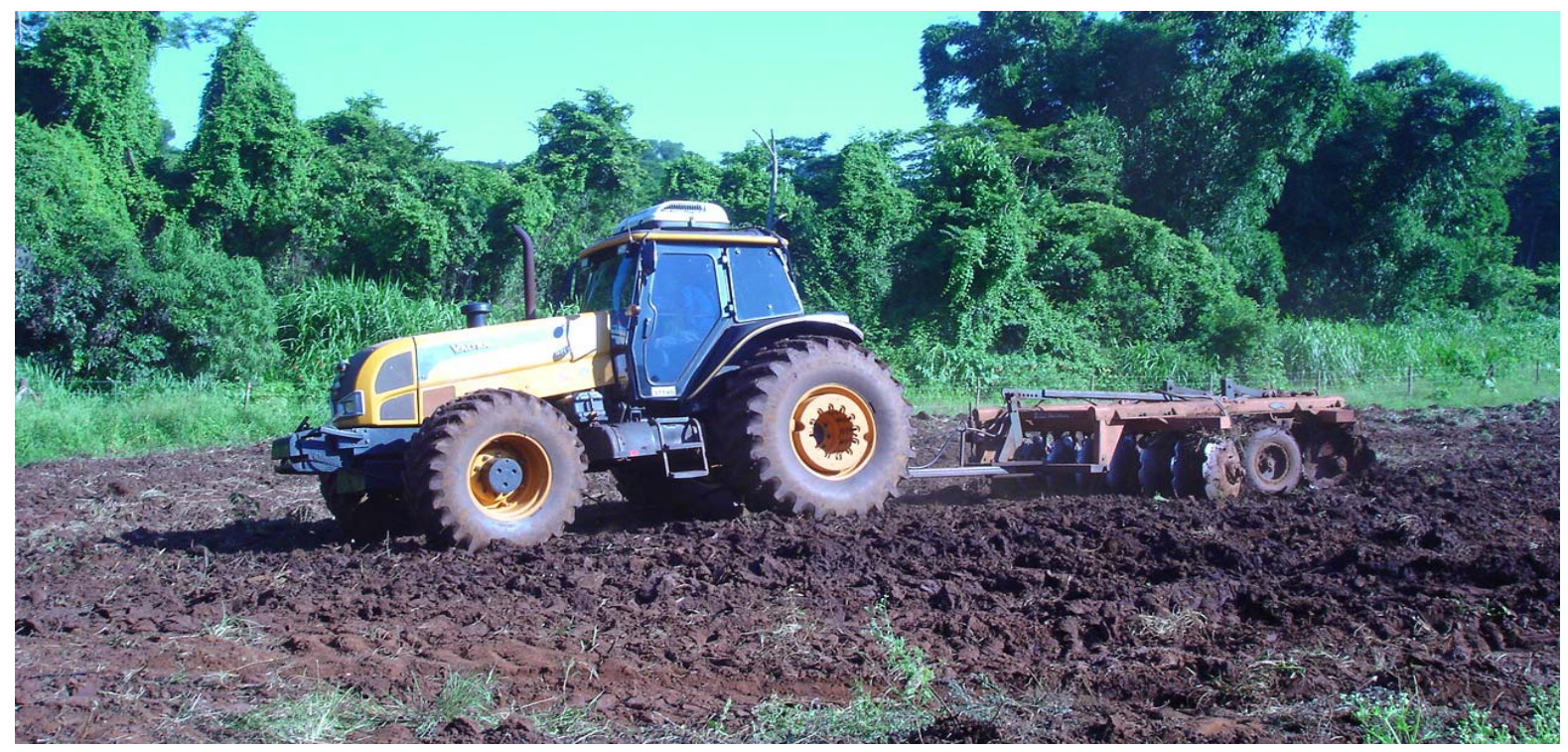

Fonte: Maccann Engenharia SS Ltda.

Figura 14 - Operação de preparo de solo

Ainda no mês de novembro de 2009 realizou-se um levantamento topográfico e cadastral do terreno com o objetivo de dimensionar a área e delimitar os pontos de divisa da gleba.

Conjuntamente foram realizados os levantamentos planimétricos e altimétricos. As medições foram executadas com equipamento de medição denominado Estação Total, marca Topcon, modelo GTS 213, com precisão angular de cinco segundos (Figura 15), por equipe terceirizada.

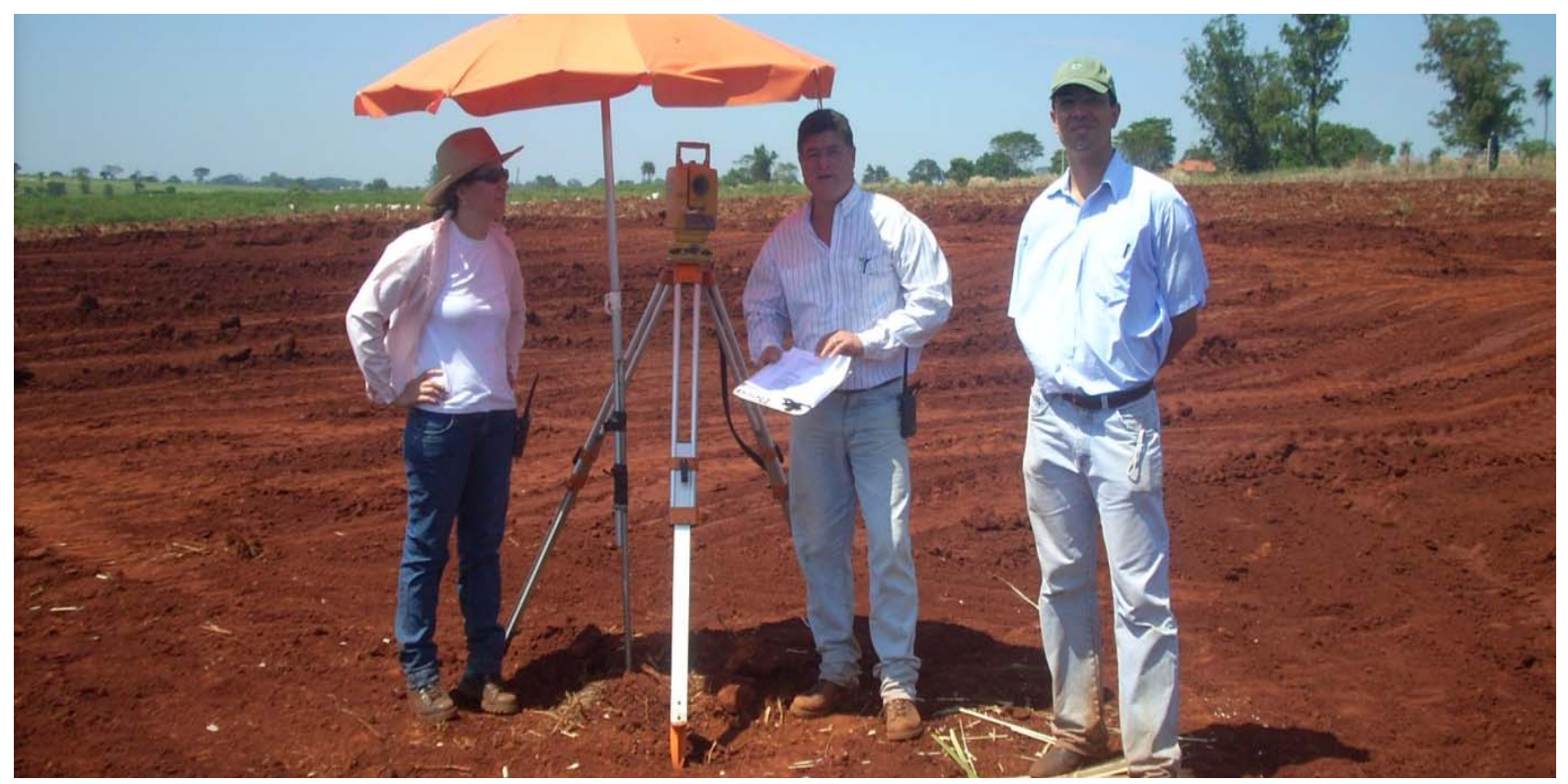

Fonte: Maccann Engenharia SS Ltda.

Figura 15 - Execução de levantamento topográfico 
Posteriormente os dados foram tratados em software específico para medições topográficas denominado TopoEVNC. A área total da gleba, apurada no levantamento foi de 23,67 ha com perímetro de 1.882,79 m. As linhas de nível do terreno foram geradas automaticamente pelo software e demarcadas de 5,00 em 5,00 m de desnível vertical (Anexo B).

Por se tratar de área anteriormente utilizada para plantio de culturas anuais verificou-se a existência de sistematização do terreno com de terraços préexistentes, motivo que dispensou a execução de novas estruturas de contenção das águas pluviais.

(iii) Definição do layout

Posteriormente executaram-se os projetos de implantação e layout com a utilização do software CADian@). As áreas foram definidas e dimensionadas conforme apresentado no quadro 3 e apresentadas no (Anexo C)

Observa-se que o layout de operações foi projetado com a finalidade de proporcionar o manejo rotacionado dos animais nos piquetes, conforme preconizou Paniago (2002).

\begin{tabular}{|c|c|c|c|}
\hline Id. Glebas & Descrição & Área (ha) & Utilização \\
\hline P1 & Piquete 1 & 2,08 & Panicum maximum cv Mombaça \\
\hline $\mathrm{P} 2$ & Piquete 2 & 1,86 & Panicum maximum cv Mombaça \\
\hline P3 & Piquete 3 & 1,72 & Brachiaria brizantha cv Marandu \\
\hline P4 & Piquete 4 & 2,30 & Brachiaria brizantha cv Marandu \\
\hline P5 & Piquete 5 & 1,74 & Brachiaria brizantha cv Marandu \\
\hline P6 & Piquete 6 & 2,19 & Brachiaria brizantha cv Marandu \\
\hline P7 & Piquete 7 & 1,95 & Panicum maximum cv Mombaça \\
\hline P8 & Piquete 8 & 2,12 & Panicum maximum cv Mombaça \\
\hline G1 & Gleba 1 & 3,98 & Cana de açúcar \\
\hline $\mathrm{G} 2$ & Gleba 2 & 2,05 & Reserva \\
\hline Outras 1 & Estradas e carreadores & 1,26 & Estradas e carreadores \\
\hline Outras 2 & Instalações & 0,42 & Área de manejo e confinamento \\
\hline Total & & 23,67 & \\
\hline
\end{tabular}

Fonte: Maccann Engenharia SS Ltda.

Quadro 3 - Identificação, descrição e áreas da gleba 
(iv) Levantamento pedológico e climático

Após a definição da utilização das áreas da gleba procedeu-se a determinação: (i) do tipo de solo da gleba; (ii) da caracterização do clima da região; (iii) das análise dos solos da gleba; (iv) prescrição de corretivos e adubos.

O solo da área experimental é classificado como Latossolo Vermelho escuro, argiloso, distrófico (EMPRAPA, 2010).

De acordo com Bufon et al. (2004), as características climáticas da região, segundo o Sistema Internacional de Köeppen, são do tipo CWA, caracterizado por ser mesotérmico de inverno seco em que a temperatura média do mês mais frio é inferior a $18^{\circ} \mathrm{C}$ e a do mês mais quente ultrapassa $22^{\circ} \mathrm{C}$. Os ventos predominantes são alíseos com velocidade média de $5,4 \mathrm{Km} / \mathrm{h}$, podendo atingir valores máximos de até $7 \mathrm{Km} / \mathrm{h}$. O total das chuvas do mês mais seco não ultrapassa $30 \mathrm{~mm}$. O índice pluviométrico desse tipo climático varia entre 1.100 e 1.700 mm diminuindo a precipitação de leste para oeste. A estação seca nessa região ocorre nos meses de abril a setembro, sendo julho o mês em que atinge a máxima intensidade. O período mais chuvoso oscila entre janeiro e fevereiro. A umidade média anual do ar é de $70 \%$.

Para determinar a necessidade de correção dos solos e prescrição de adubação, realizou-se - no mês de outubro de 2009 - as análises dos solos no Laboratório de Ciências Agrárias / Solos do Departamento de Zootecnia da Faculdade de Zootecnia e Engenharia de Alimentos (FZEA) da Universidade de São Paulo (USP), conforme tabela 24:

Tabela 24 - Resultado das análises dos solos da gleba

\begin{tabular}{|c|c|c|c|c|c|c|c|c|c|c|c|c|c|c|c|}
\hline \multirow[t]{2}{*}{$\begin{array}{c}\mathrm{N}^{\circ} \\
\text { amostra }\end{array}$} & \multirow[t]{2}{*}{$\begin{array}{c}\text { Id. } \\
\text { Amostra }\end{array}$} & \multirow[t]{2}{*}{ Área } & \multirow[t]{2}{*}{$\begin{array}{l}\text { Área } \\
\text { (ha) }\end{array}$} & \multirow[t]{2}{*}{$\begin{array}{c}\mathrm{pH} \\
\mathrm{CaCl}_{2}\end{array}$} & $P$ & $S$ & $\mathrm{~K}$ & $\mathrm{Ca}$ & $\mathrm{Mg}$ & $\mathrm{H}+\mathrm{Al}$ & $\mathrm{Al}$ & СтC & SB & V & $\mathrm{m}$ \\
\hline & & & & & $\mathrm{mg}$ & $\mathrm{dm}^{3}$ & \multicolumn{7}{|c|}{$\mathrm{mmoic} / \mathrm{dm}^{3}$} & \multicolumn{2}{|c|}{$\%$} \\
\hline 142104 & 1 & $G C^{*}$ & \multirow{2}{*}{2,00} & 6,2 & 78 & 8 & 1,6 & 54 & 35 & 19 & $\mathrm{TR}$ & 110 & 91 & 83 & TR \\
\hline 142105 & 2 & $\mathrm{GC}^{*}$ & & 6,1 & 71 & 10 & 3,0 & 49 & 33 & 20 & TR & 105 & 85 & 81 & TR \\
\hline 142106 & 3 & P1-P8** & \multirow{3}{*}{16,00} & 6,1 & 23 & 7 & 2,7 & 56 & 36 & 22 & TR & 117 & 95 & 81 & TR \\
\hline 142107 & 4 & P1-P8** & & 6,0 & 38 & 6 & 3,6 & 52 & 34 & 24 & TR & 114 & 90 & 79 & TR \\
\hline 142108 & 5 & P1-P8** & & 6,2 & 43 & 8 & 3,0 & 50 & 37 & 18 & 1 & 108 & 90 & 83 & 1 \\
\hline 142109 & 6 & $\mathrm{GR}^{\star \star \star}$ & 2,00 & 5,8 & 81 & 6 & 3,2 & 49 & 29 & 34 & TR & 115 & 81 & 70 & TR \\
\hline
\end{tabular}

* Gleba cana

** Piquetes 1, 2, 3, 4, 5, 6, 7 e 8

*** Gleba reserva 
A recomendação das práticas corretivas foi realizada pelo Eng $^{\circ}$ Agrônomo Prof. Dr. Pedro Henrique de Cerqueira Luz - CREA 0601365492 - e Responsável Técnico do Laboratório de Ciência Agrárias / Solos da FZEA. As recomendações foram: (i) sem necessidade de práticas corretivas para os piquetes 1 à 8 , destinados ao plantio das pastagens; (ii) $700 \mathrm{Kg} / \mathrm{ha}$ da formulação 05:10:15 na linha de plantio da cana de açúcar. As práticas recomendadas foram realizadas por ocasião do estabelecimento das culturas.

(v) Estabelecimento e condução da cultura de cana de açúcar

A implantação da cultura da cana de açúcar foi realizada no mês de dezembro de 2009, na gleba 1 . As mudas utilizadas no plantio foram multiplicadas no ano anterior em viveiro localizado no campus da USP de Pirassununga e obtidas do $I A C^{50}$.pelo prof. Dr. Luis Felipe Prada e Silva.

Para execução do plantio o terreno foi previamente preparado utilizando-se um trator de pneus com $180 \mathrm{cv}$ de potência e grade intermediária com discos 32x26" - côncavos recortados (Figura 16).

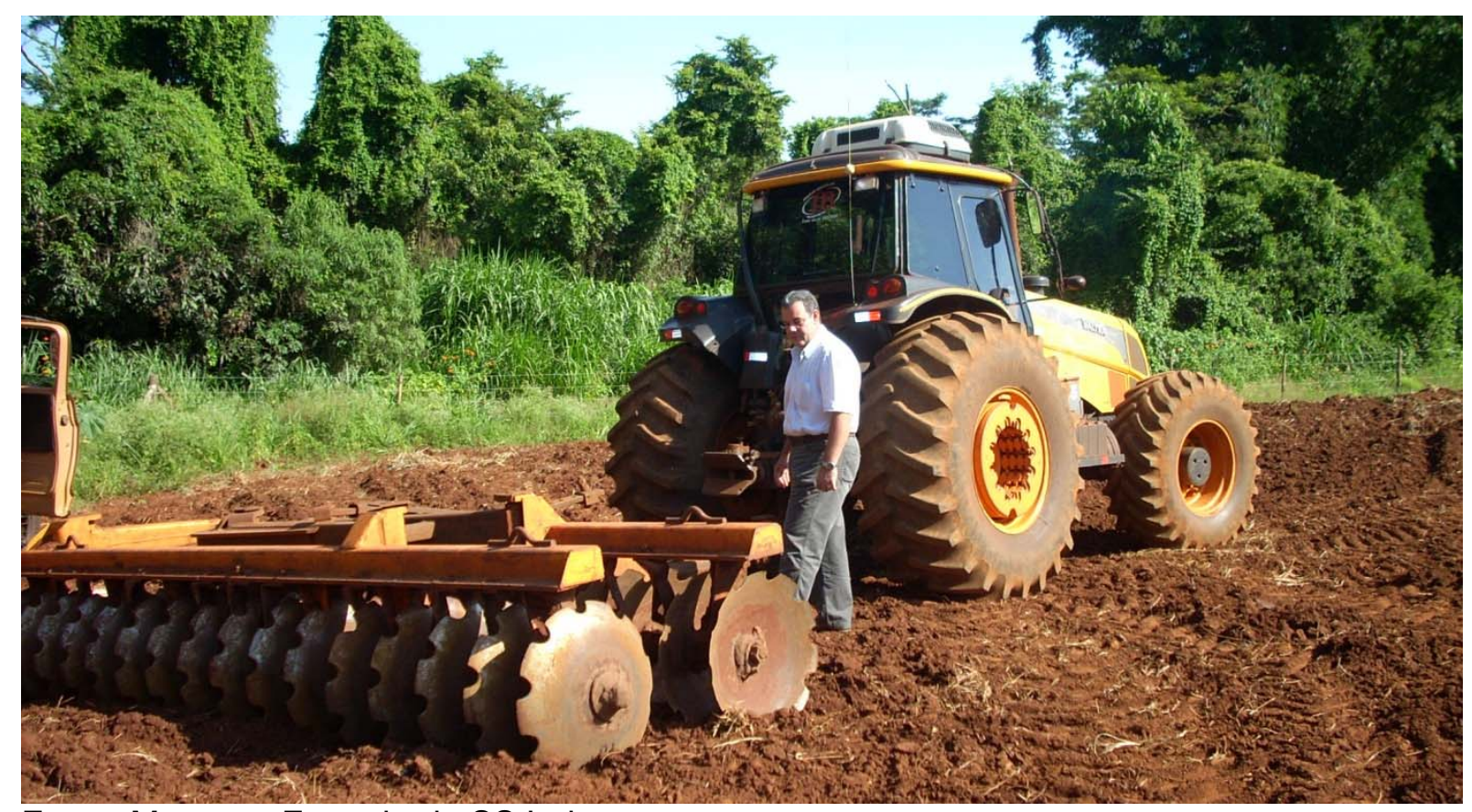

Fonte: Maccann Engenharia SS Ltda.

Figura 16 - Preparo de solo para implantação da cultura da cana de açúcar

${ }^{50}$ Instituto Agronômico de Campinas. 
Para o plantio utilizou-se um trator de pneus de $150 \mathrm{cv}$ de potência e acoplado a este um sulcador / adubador de duas hastes de plantio (Figura 17).

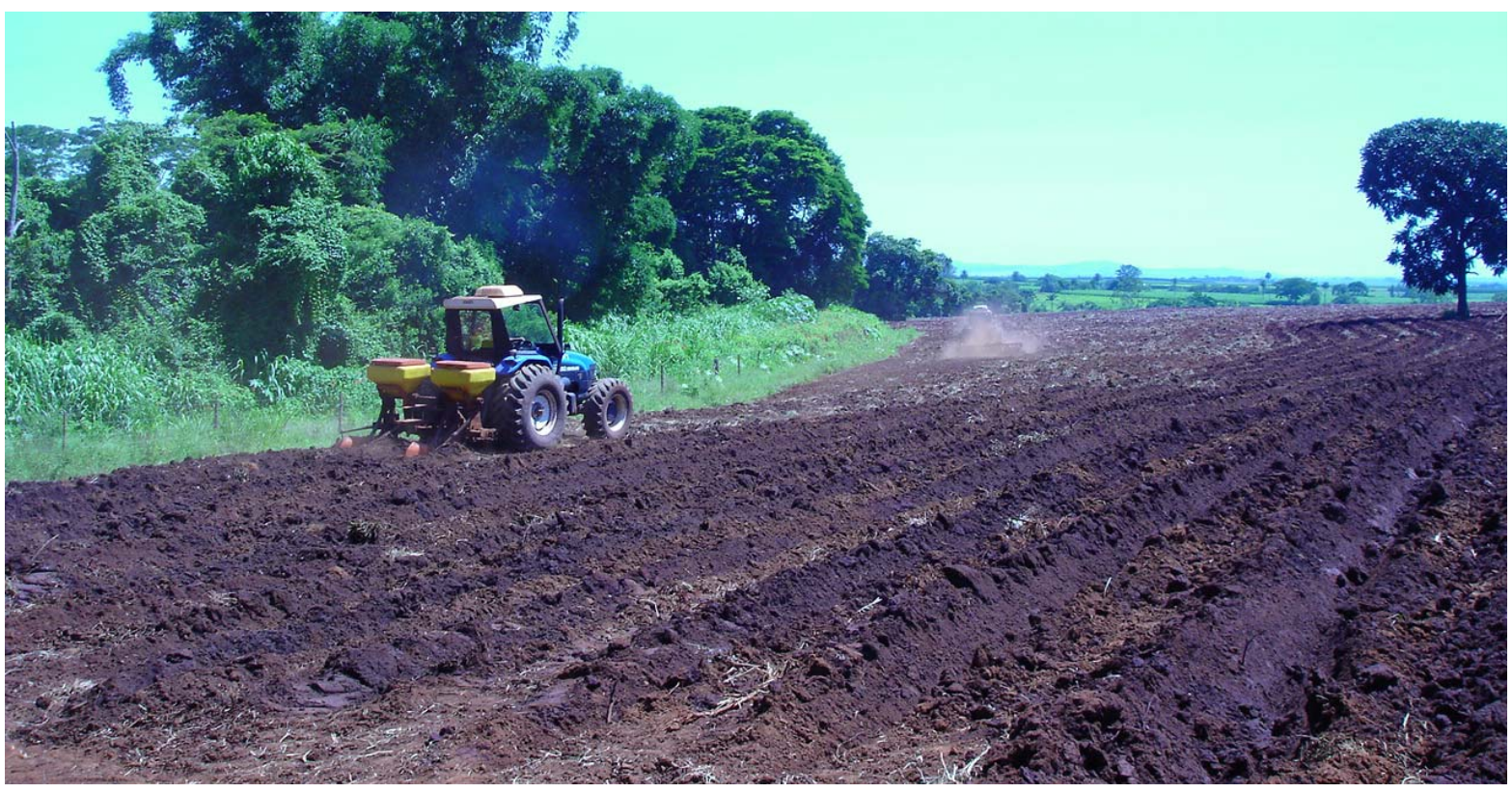

Fonte: Maccann Engenharia SS Ltda.

Figura 17 - Trator de pneus e equipamento agrícola utilizado para o plantio da cana de açúcar

O espaçamento entre linhas de plantio foi de 1,20m. O Plantio das mudas foi realizado manualmente por 6 trabalhadores rurais e 1 fiscal de turma (Figura 18).



Fonte: Maccann Engenharia SS Ltda.

Figura 18 - Colocação das mudas nas linhas de plantio de cana de açúcar 
Após a colocação das mudas na linha de plantio, a cobrição destas foi realizada com um trator de pneus de $75 \mathrm{cv}$ de potência e equipamento agrícola denominado cobridor (Figura 19).

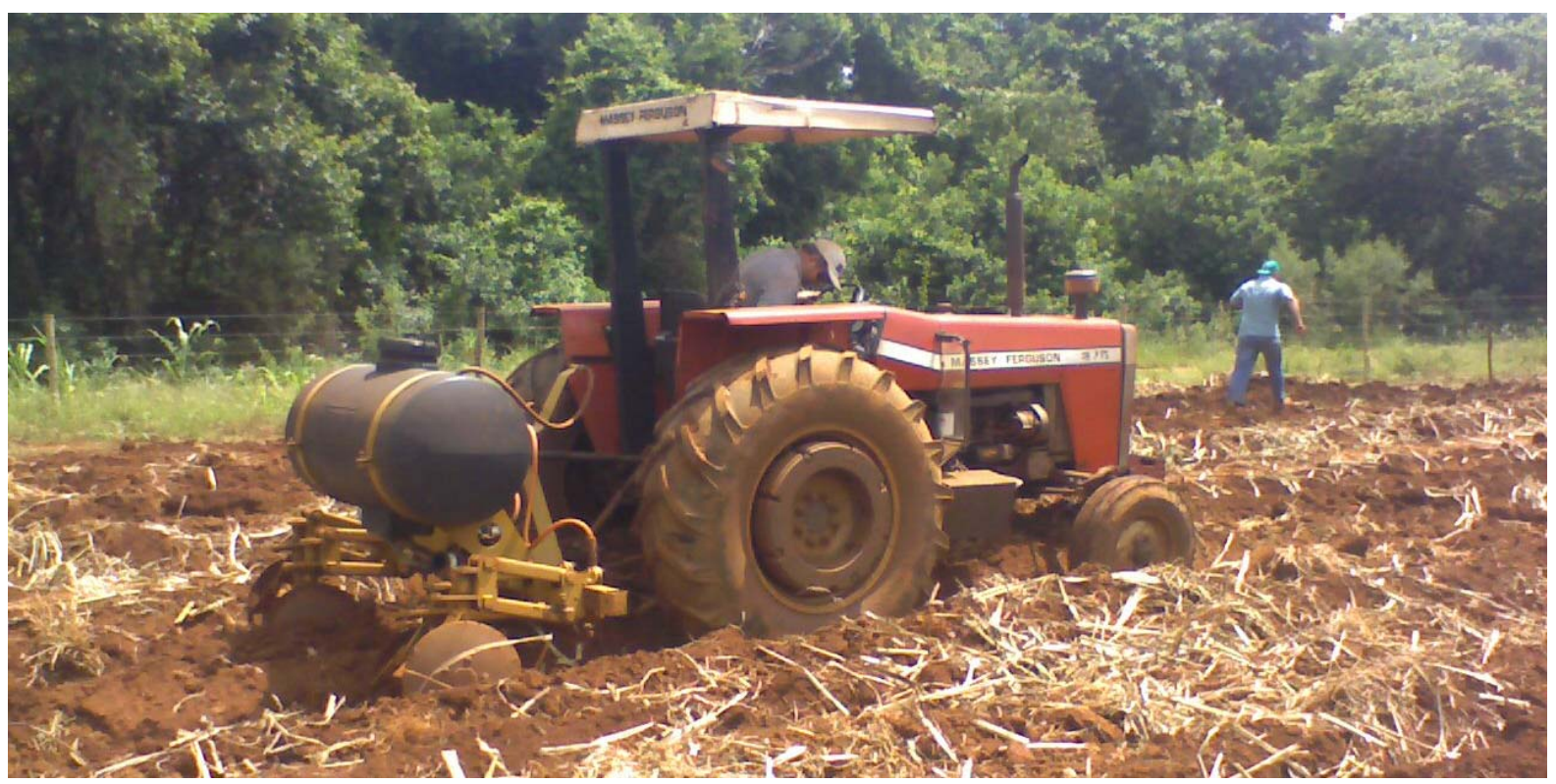

Fonte: Maccann Engenharia SS Ltda.

Figura 19 - Cobridor utilizado para o plantio da cana de açúcar

Devido à alta incidência de invasoras e após o plantio - janeiro de 2010 - foi realizado uma aplicação de herbicida com a finalidade de controlar a alta infestação de Cyperus rotundus, dentre outras invasoras de folha larga (Figura 20).

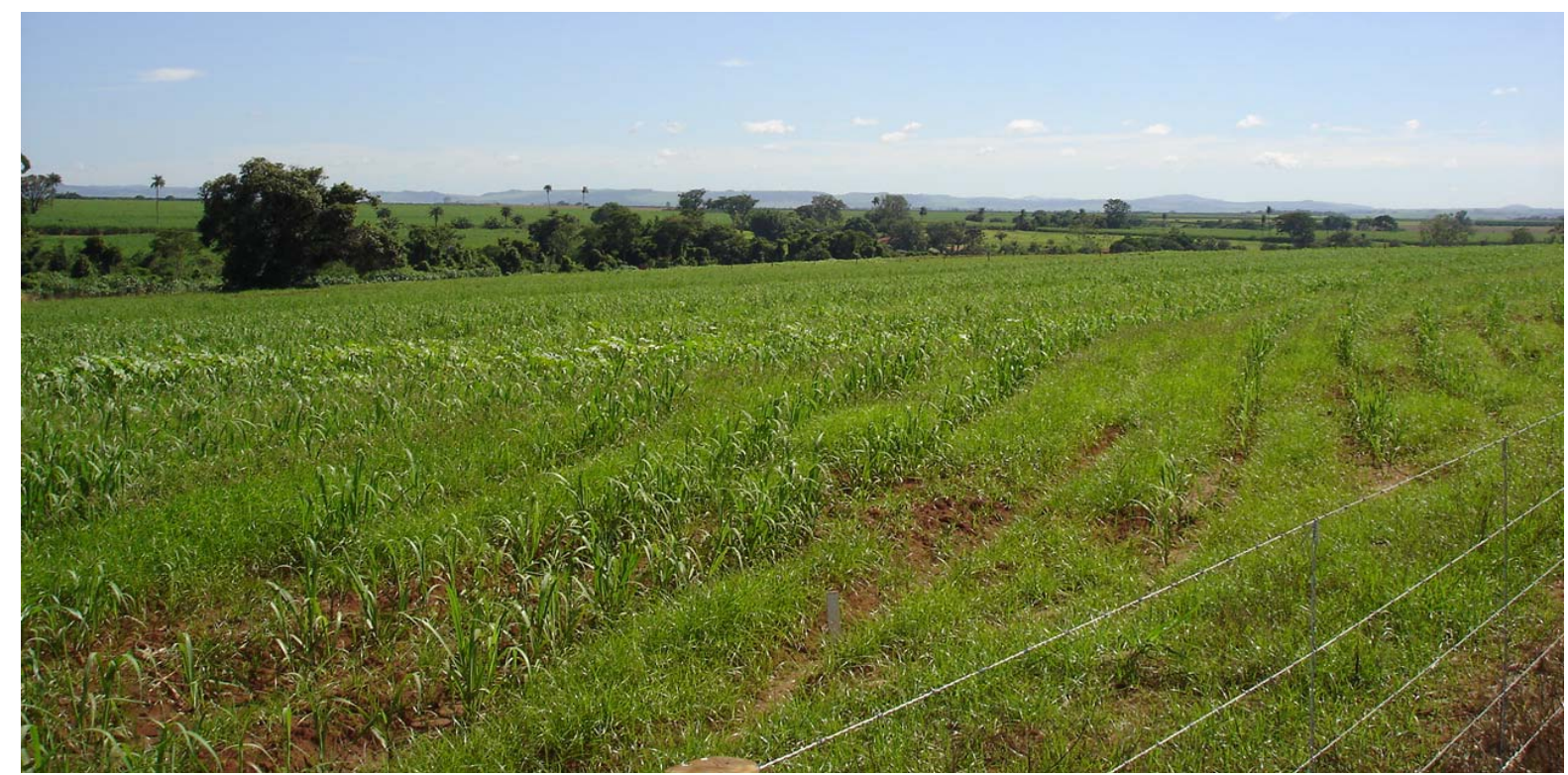

Fonte: Maccann Engenharia SS Ltda.

Figura 20 - Infestação de Cyperus rotundus no talhão de cana de açúcar 
Para tanto foi utilizado éster amina do ácido diclorofenoxiacético (2,4-D) na dose de 2,5 I/ha da formulação comercial, com volume de calda de 400 I/ha. A recomendação foi realizada pelo $\mathrm{Eng}^{\circ}$ Agrônomo Rinaldo Rodrigues - CREA 0605018370 e para a aplicação foi utilizado um trator de pneus de 75 cv de potência com pulverizador com capacidade de 2000 I de calda e pontas modelo teejet API110-02 (Figura 21).

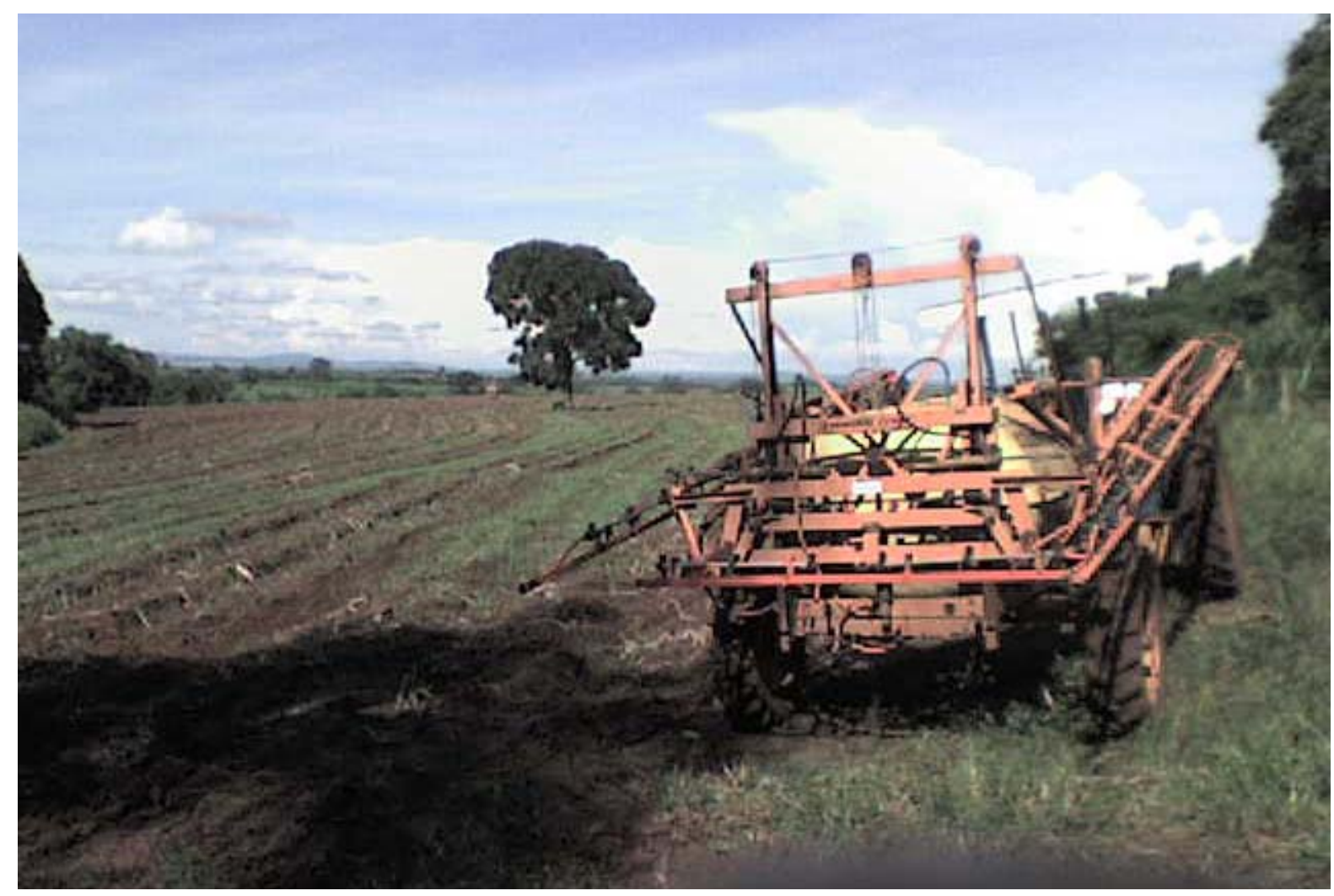

Fonte: Maccann Engenharia SS Ltda.

Figura 21 - Controle químico de invasoras na cultura de cana de açúcar

Após o estabelecimento da cultura, executou-se - no mês de março de 2010 - uma operação mecanizada de cultivo simples no talhão. Foi utilizado um trator de pneus de $150 \mathrm{cv}$ e equipamento denominado cultivador (Figura 22).

Finalizou-se a implantação do talhão de cana de açúcar destinado à alimentação dos animais no sistema. Todos os serviços realizados para o plantio e demais práticas culturais adotadas e executadas foram terceirizadas e incorreram em desembolsos. 


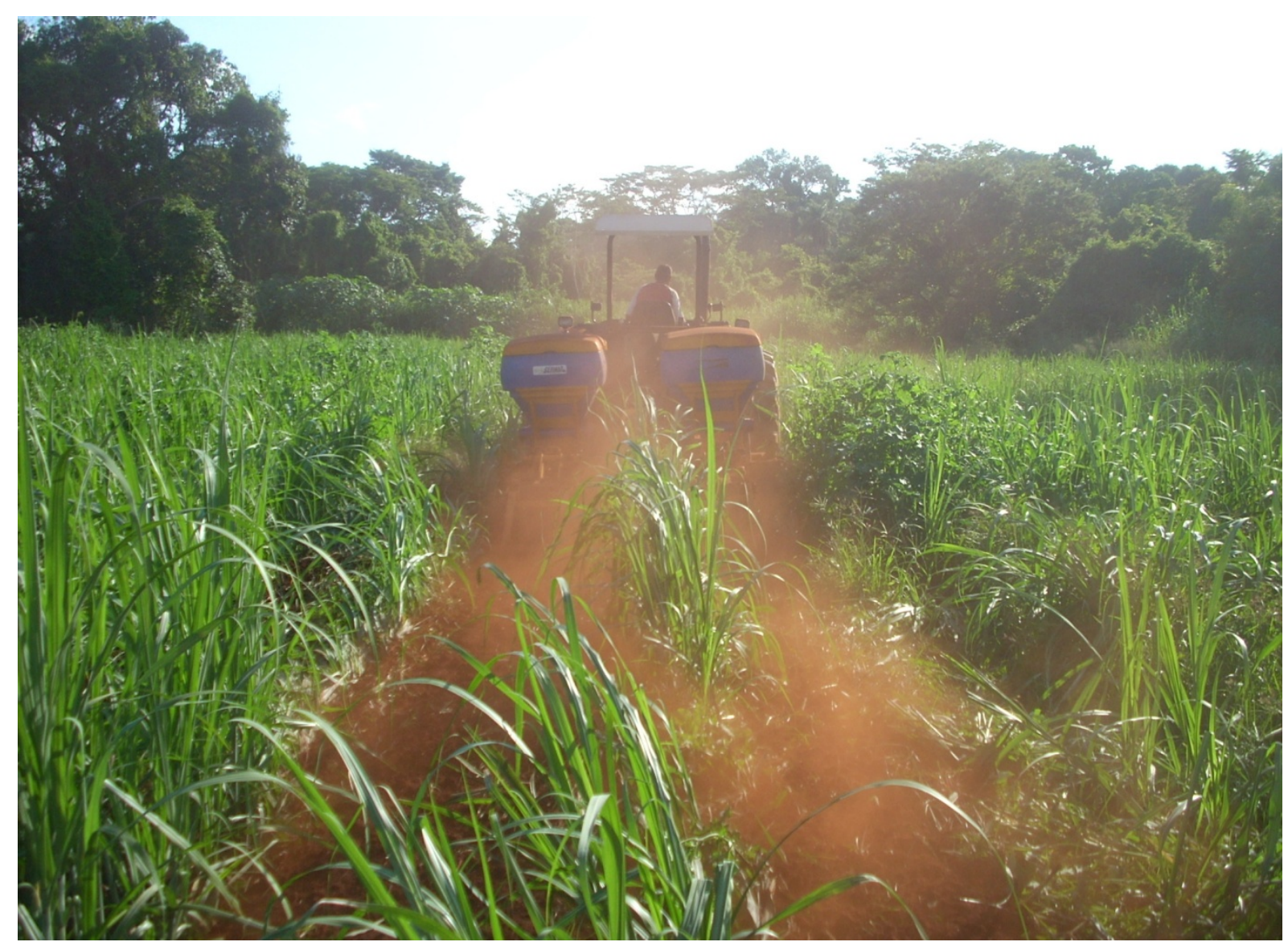

Fonte: Maccann Engenharia SS Ltda.

Figura 22 - Operação de cultivo simples

Para a manutenção da lavoura de cana de açúcar, projetou-se um fluxo de caixa de 30 anos - 2009 até 2038, sendo o ano de 2009 considerado como ano 1 do projeto e o ano de 2038 o ano 30 - as práticas a serem executadas no horizonte temporal da análise foram: (i) Reforma do canavial a cada 7 cortes, nos anos 9 (2017), 17 (2025) e 25 (2033) do empreendimento; (ii) Correção, adubação de plantio e de cana-soca conforme preconizaram Vitti et. al (2005), realizadas anualmente, exceto nos anos de formação da lavoura. As operações mecanizadas e outros desembolsos estão representados no apêndice F.

(vi) Estabelecimento e manutenção das pastagens

A implantação das pastagens ocorreu de forma atípica em função dos altos índices pluviométricos, conforme os registros da estação metereológica da Coordenadoria do Campus de Pirassununga (CCPS) da USP (Figura 23). 


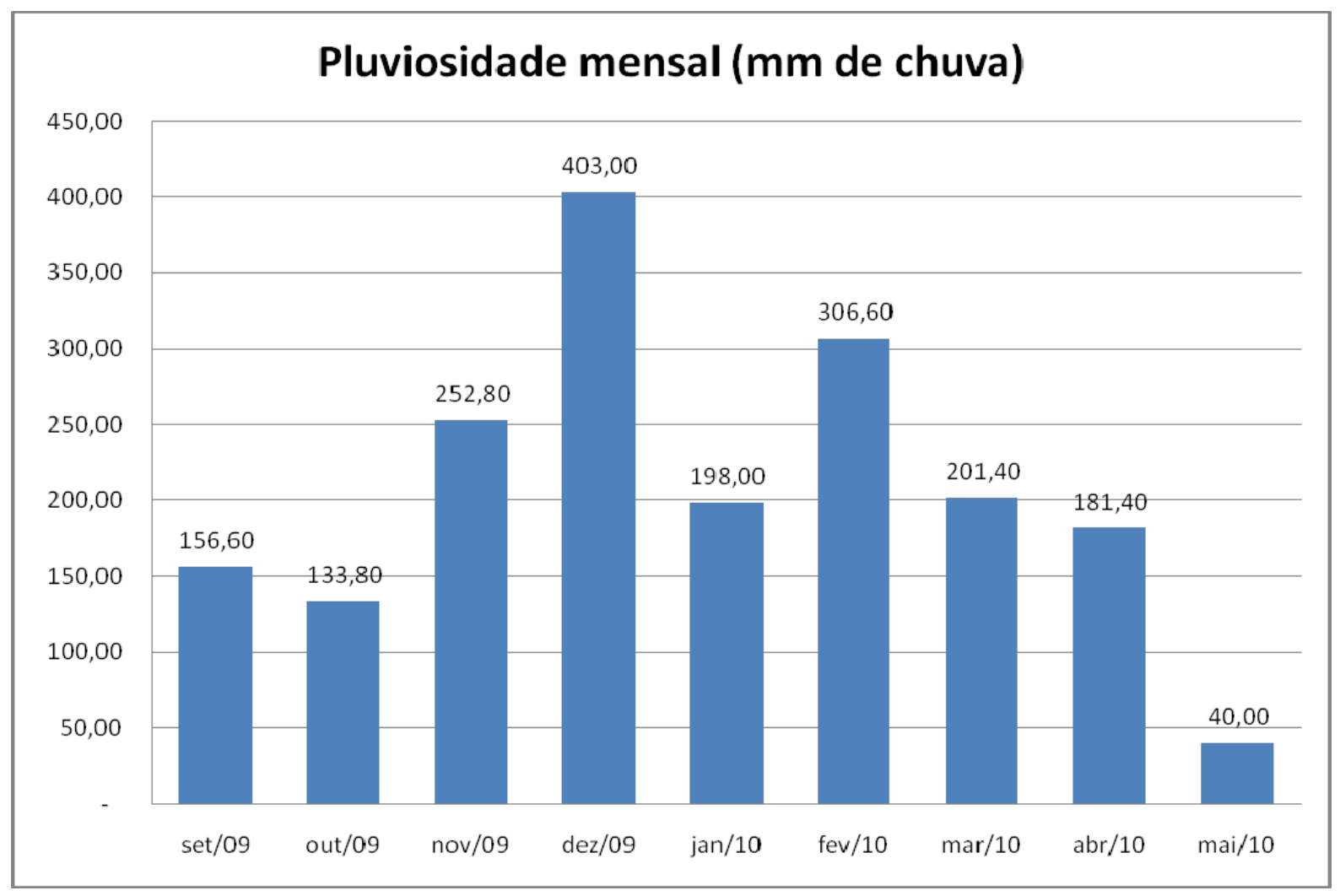

Fonte: CCPS. Estação meteorológica. Disponível em: <http://www.usp.br/ccps>. Acesso em: junho de 2010.

Figura 23 - Índices pluviométricos totais registrados nos meses de setembro de 2009 a maio do ano de 2010

Destaca-se que, contrário à cultura da cana de açúcar, as pastagens necessitaram da preparação mais elaborada para seu estabelecimento. Os altos índices de pluviosidade registrados impossibilitaram o preparo imediato do terreno, fazendo-se assim necessário o controle das invasoras - com o objetivo de diminuir a massa verde existente - para após serem executadas as operações mecanizadas de preparo de solo para o plantio.

O controle das invasoras foi realizado no mês de fevereiro de 2010, por meio da aplicação de herbicidas em área total nas glebas destinadas ao plantio das pastagens. Foram utilizados para tanto os equipamentos agrícolas identificados na figura 22, a saber: trator de pneus de $75 \mathrm{cv}$ de potência e pulverizador com capacidade de 2000 I de calda e pontas modelo teejet API-110-02; (ii) herbicidas: Glifosato marca comercial Roundup mais 2,4D + Plicoram marca comercial Tordon. As doses utilizadas na aplicação foram: 5 I/ha Roundup e 2 I/ha de Tordon. A vazão do equipamento foi de 400 l/ha. A recomendação foi efetuada pelo Eng ${ }^{\circ}$ Agrônomo Rinaldo Rodrigues - CREA 0605018370. 
O resultado foi satisfatório, conforme apresenta a figura 24, comparativamente à situação inicial apresentada na figura 13. Nota-se o efeito fitotóxico promovido pela ação dos herbicidas.

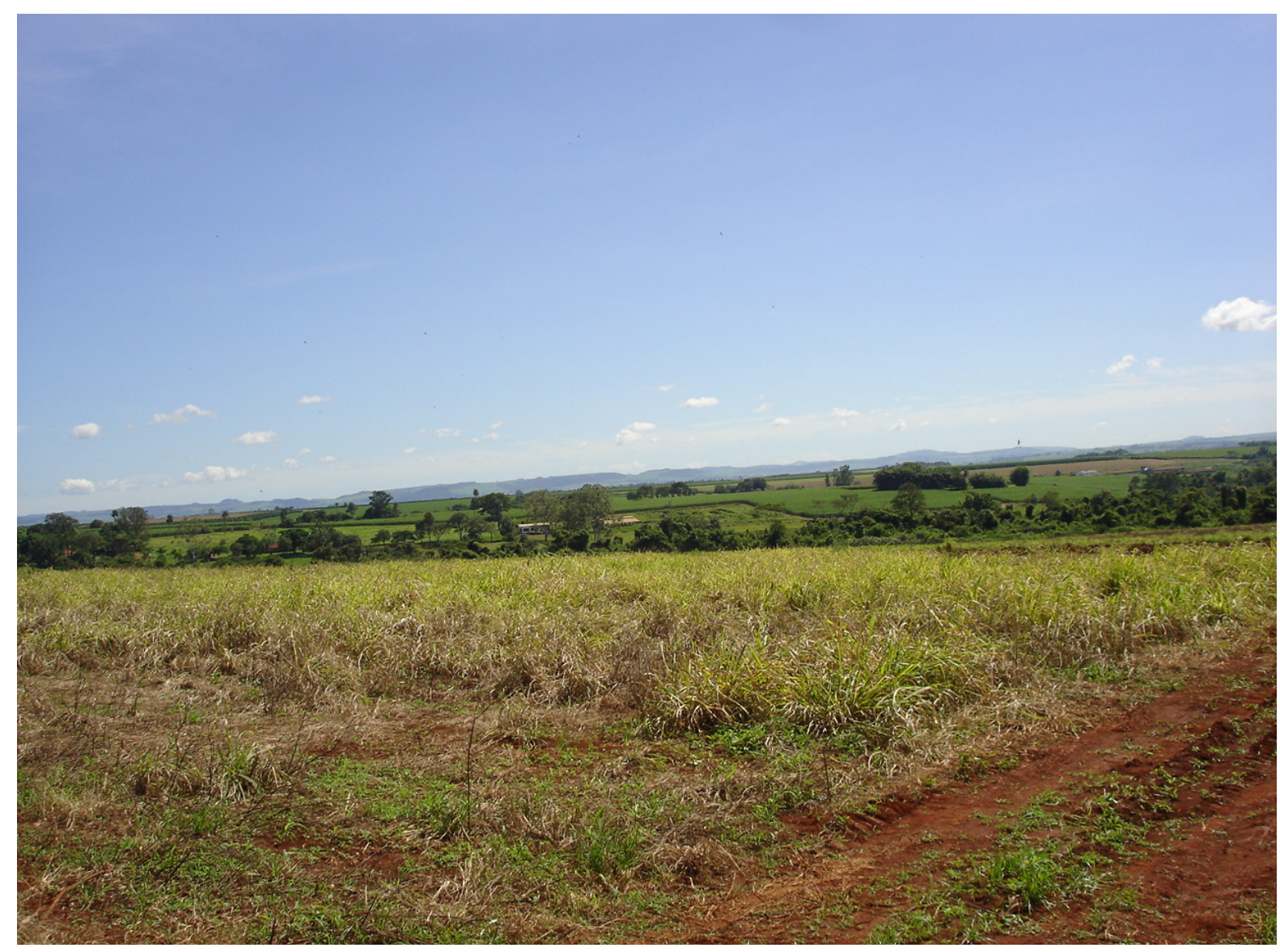

Fonte: Maccann Engenharia SS Ltda.

Figura 24 - Aspecto das invasoras após aplicação dos herbicidas

Para a execução do preparo de solo utilizou-se 2 operações mecanizadas: preparo com grade aradora e preparo com grade intermediária.

No final do mês de fevereiro de 2010 inicialmente utilizou-se um trator de pneus de 180 cv de potência e grade aradora com discos côncavos recortados (16 X 32"), conforme ilustrado na figura 14.

Notou-se que embora o porte do equipamento e a eficiência em relação à profundidade de corte, não foram suficientes para eliminar totalmente a massa verde, fato devido à continuidade das chuvas, encharcamento e características físicas do solo (Figura 25). 


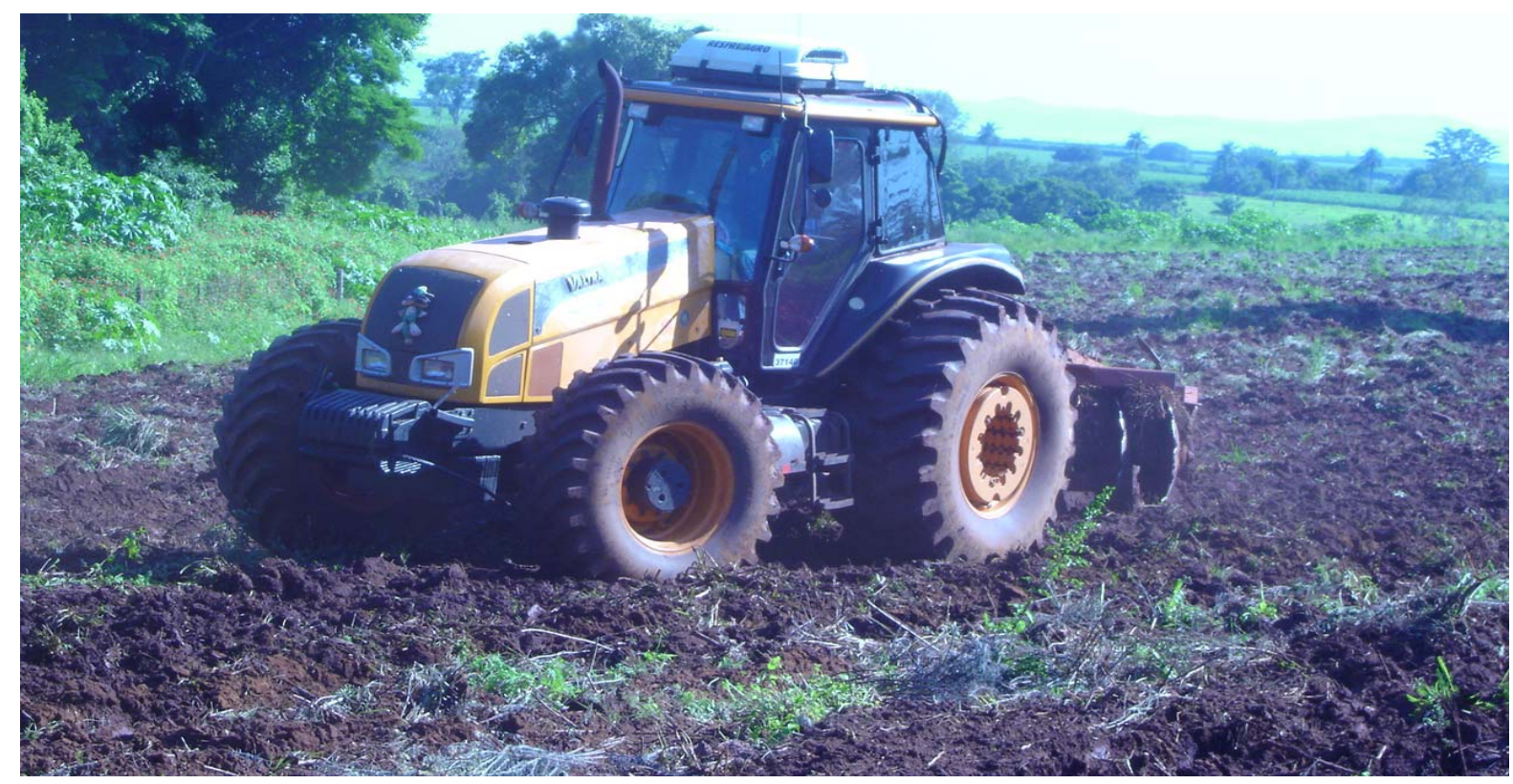

Fonte: Maccann Engenharia SS Ltda.

Figura 25 - Operação de gradagem após aplicação dos herbicidas

Realizou-se uma segunda operação com grade intermediária com um trator de pneus com 180 cv de potência e grade intermediária com discos - 32 × 26" côncavos recortados (Figura 16).

O resultado final das operações mecanizadas foi considerado satisfatório, porém o solo ainda apresentava restos de massa verde e quantidade de torrões, por consequência da alta umidade ainda presente no solo (Figura 26).

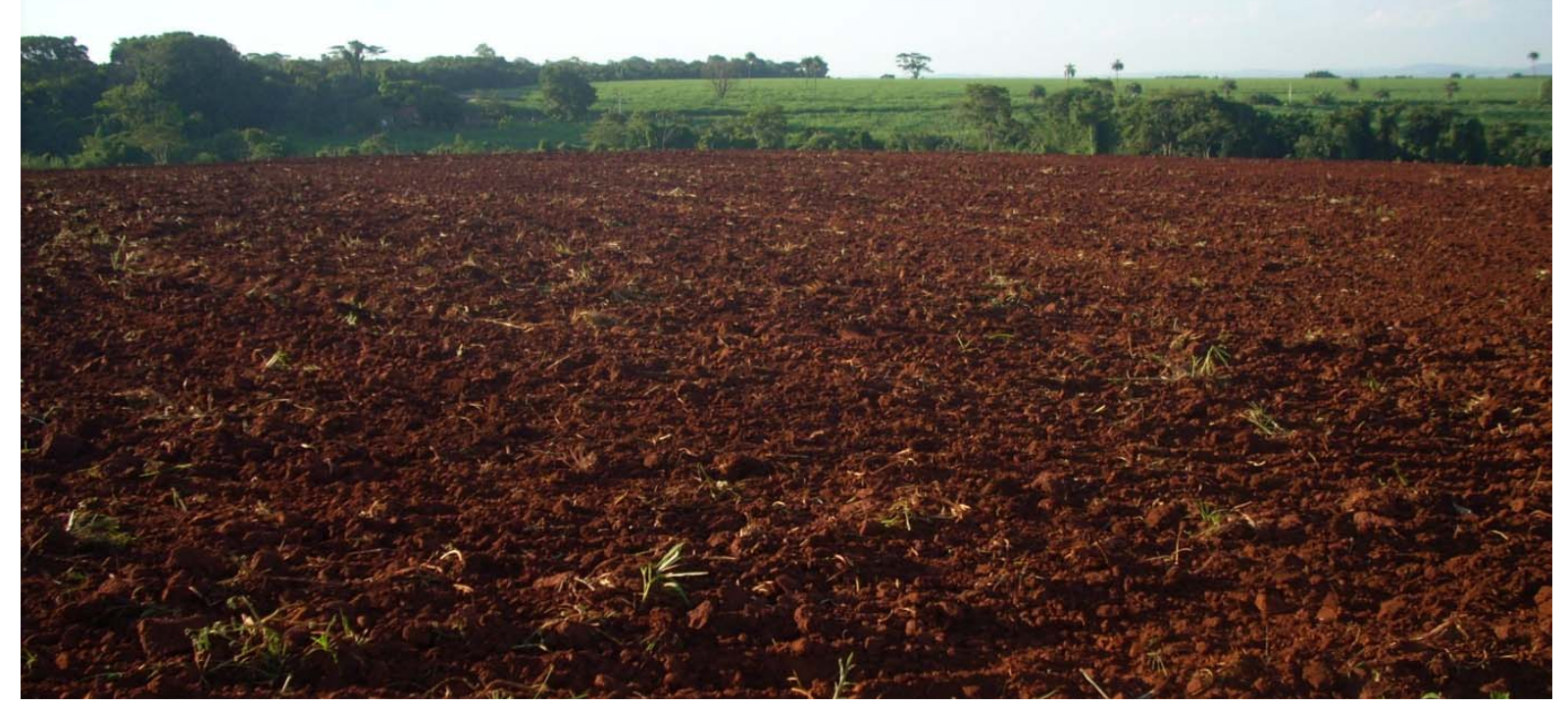

Fonte: Maccann Engenharia SS Ltda.

Figura 26 - Aspecto da gleba após operações de preparo de solo para plantio das pastagens 
Para não promover maior compactação do solo e tendo em vista o final do mês de fevereiro e início do mês de março de 2010, optou-se pela finalização das operações de preparo de solo e início da operação de semeadura das pastagens.

Para a semeadura das pastagens - em 09 de março de 2010 - utilizou-se um trator de pneus de $85 \mathrm{cv}$ de potencia e equipamento agrícola denominado semeadeira / adubadeira para o lançamento das sementes ao solo (Figura 27).

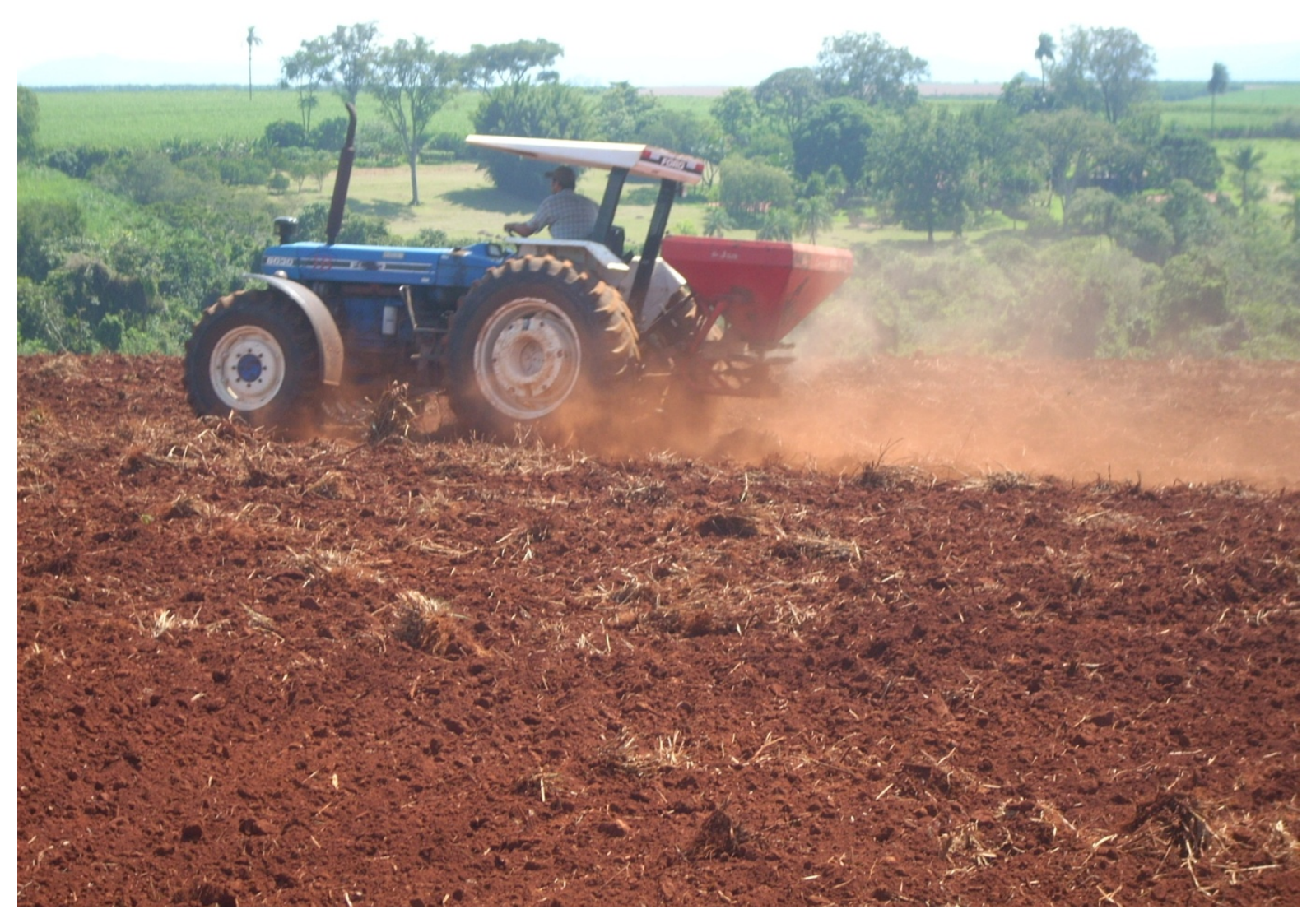

Fonte: Maccann Engenharia SS Ltda.

Figura 27 - Operação mecanizada de semeadura das pastagens

Para a semeadura do Panicum maximum cv Mombaça misturou-se às sementes superfosfato simples na proporção de 1:1. Tal prática foi executada para promover melhor distribuição das sementes na área, dada às características físicas das sementes (Figura 28). 


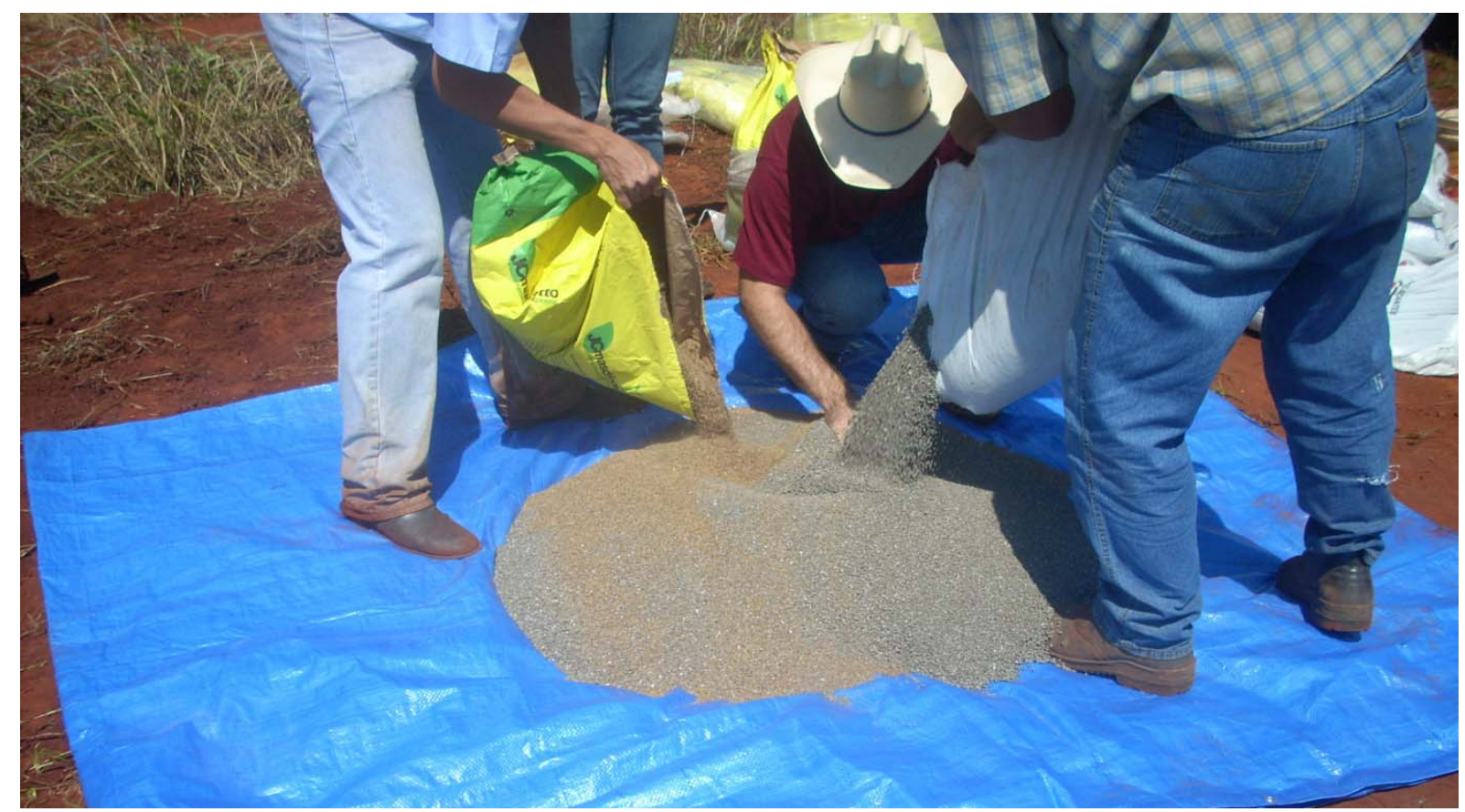

Fonte: Maccann Engenharia SS Ltda.

Figura 28 - Preparo da semente de Panicum maximum cv Mombaça

Para regulagem e aferição da semeadora, foi utilizada uma lona ráfia de polietileno e obtido o peso das sementes lançadas proporcionalmente à área de 1 hectare (Figura 29).

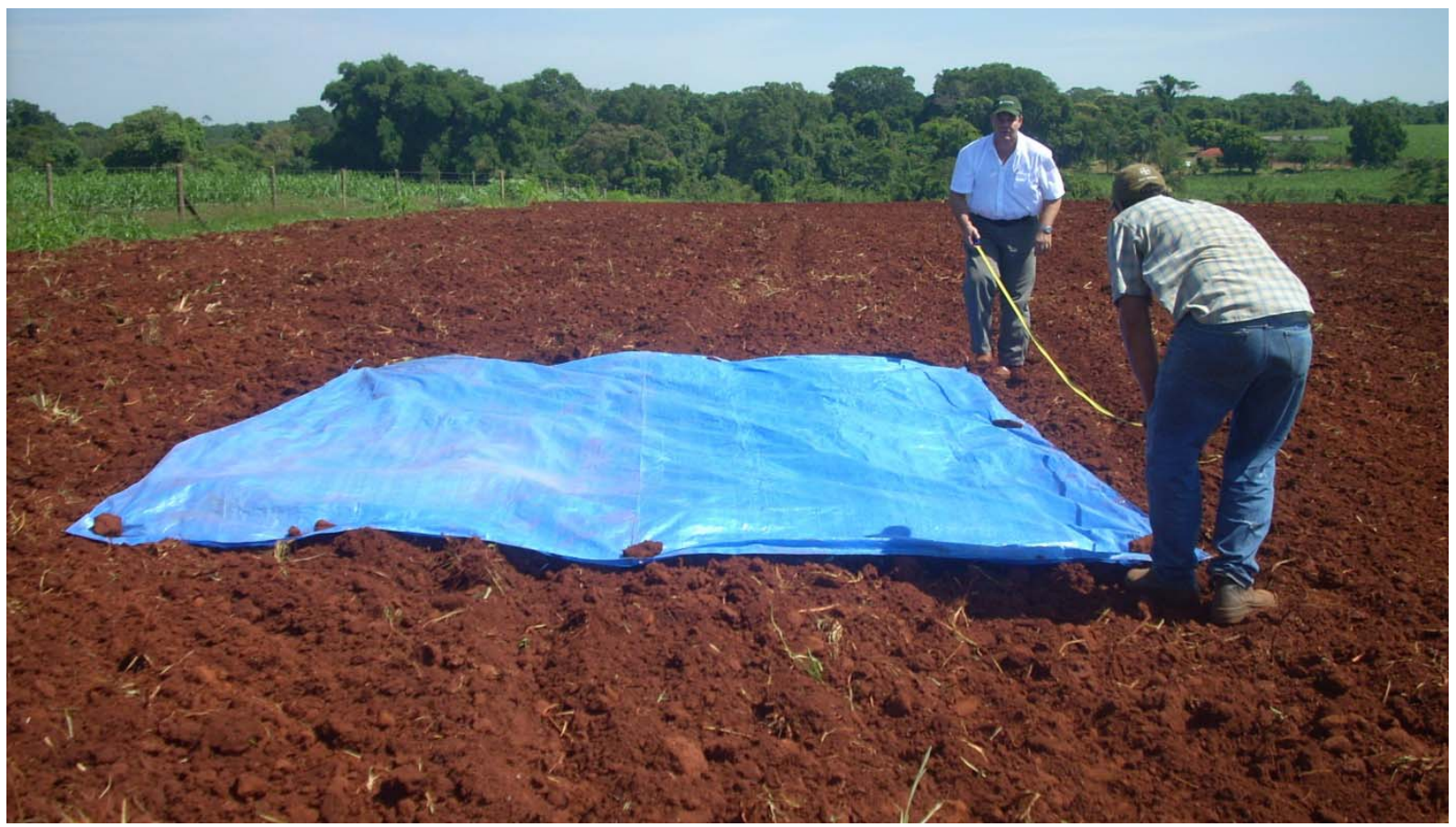

Fonte: Maccann Engenharia SS Ltda.

Figura 29 - Aferição do peso das sementes de Panicum maximum cv Mombaça, lançadas por unidade de área 
Após o lançamento das sementes utilizou-se uma trena metálica de 30 metros para verificação da quantidade de semente lançadas em $1 \mathrm{~m}^{2}$ (Figura 30).

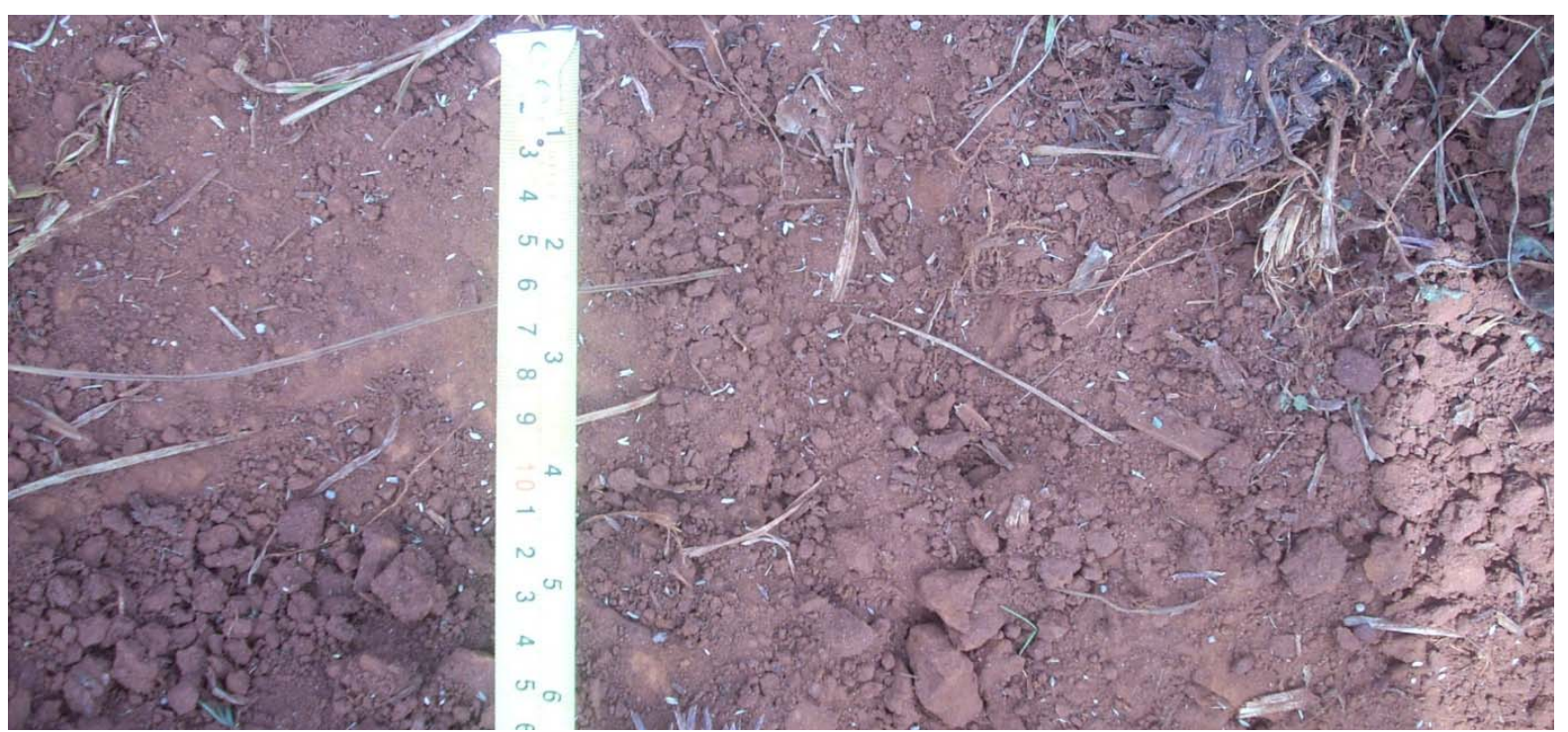

Fonte: Maccann Engenharia SS Ltda.

Figura 30 - Contagem da quantidade de sementes de Panicum maximum cv Mombaça, lançadas por unidade de área

Em relação à semeadura da Brachiaria brizantha cv Marandu foram realizados os mesmos procedimento apresento na figura 29.

Após o lançamento procedeu-se à verificação da quantidade de sementes de Brachiaria brizantha cv Marandu (Figura 31).

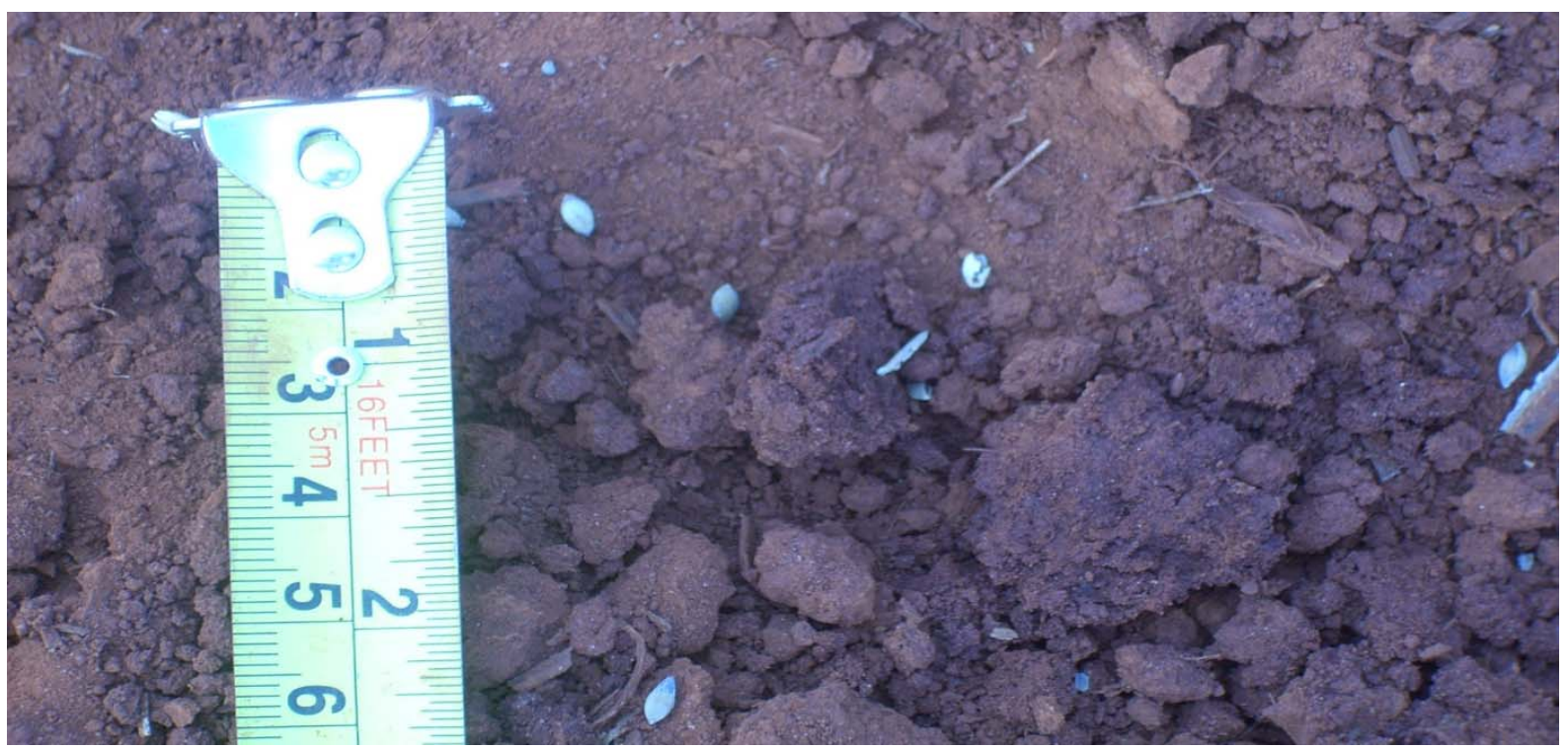

Fonte: Maccann Engenharia SS Ltda.

Figura 31 - Contagem da quantidade de sementes de Brachiaria brizantha cv Marandu, lançadas por unidade de área 
O plantio obedeceu às especificações apresentadas no quadro 3. A quantidade de sementes utilizada seguiu a recomendação do fabricante: $10 \mathrm{~kg}$ de sementes por hectare para o Panicum maximum cv. Mombaça e para a Brachiaria brizantha cv. Marandu $10 \mathrm{~kg} / \mathrm{ha}$.

Finalmente o mesmo equipamento utilizado no preparo do solo (Figura 17) foi utilizado para cobrir as sementes com uma camada de terra de $02 \mathrm{~cm}$ de altura (Figura 32).

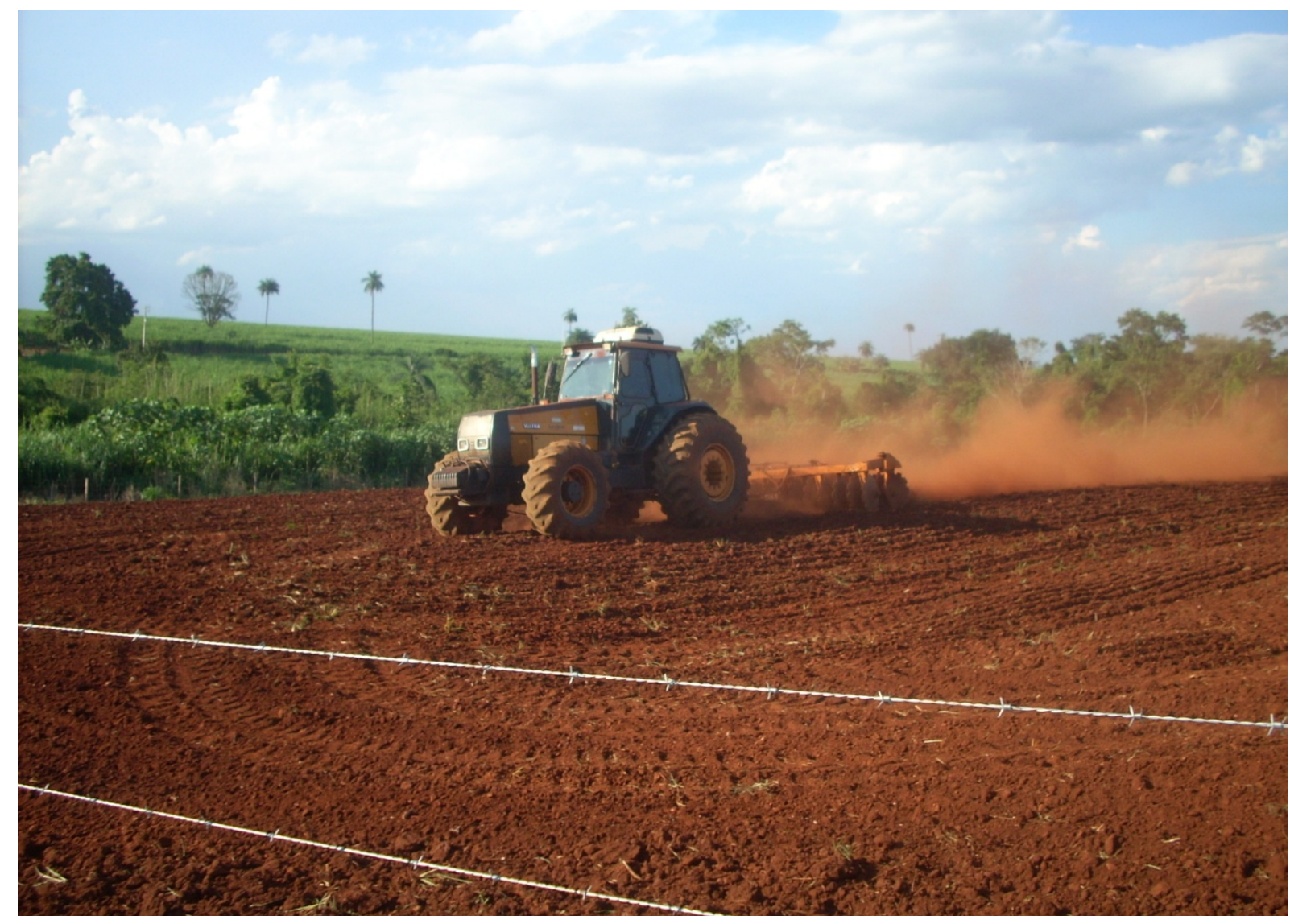

Fonte: Maccann Engenharia SS Ltda.

Figura 32 - Utilização de grade intermediária - destravada - para cobertura das sementes das pastagens

Todas as operações realizadas para o plantio das pastagens foram terceirizadas.

Após a germinação das sementes das pastagens - 20 de março de 2010 diagnosticou-se alta infestação de invasoras em toda a área utilizada na implantação das pastagens, fato que comprometeria o desenvolvimento das pastagens (Figura 33). 


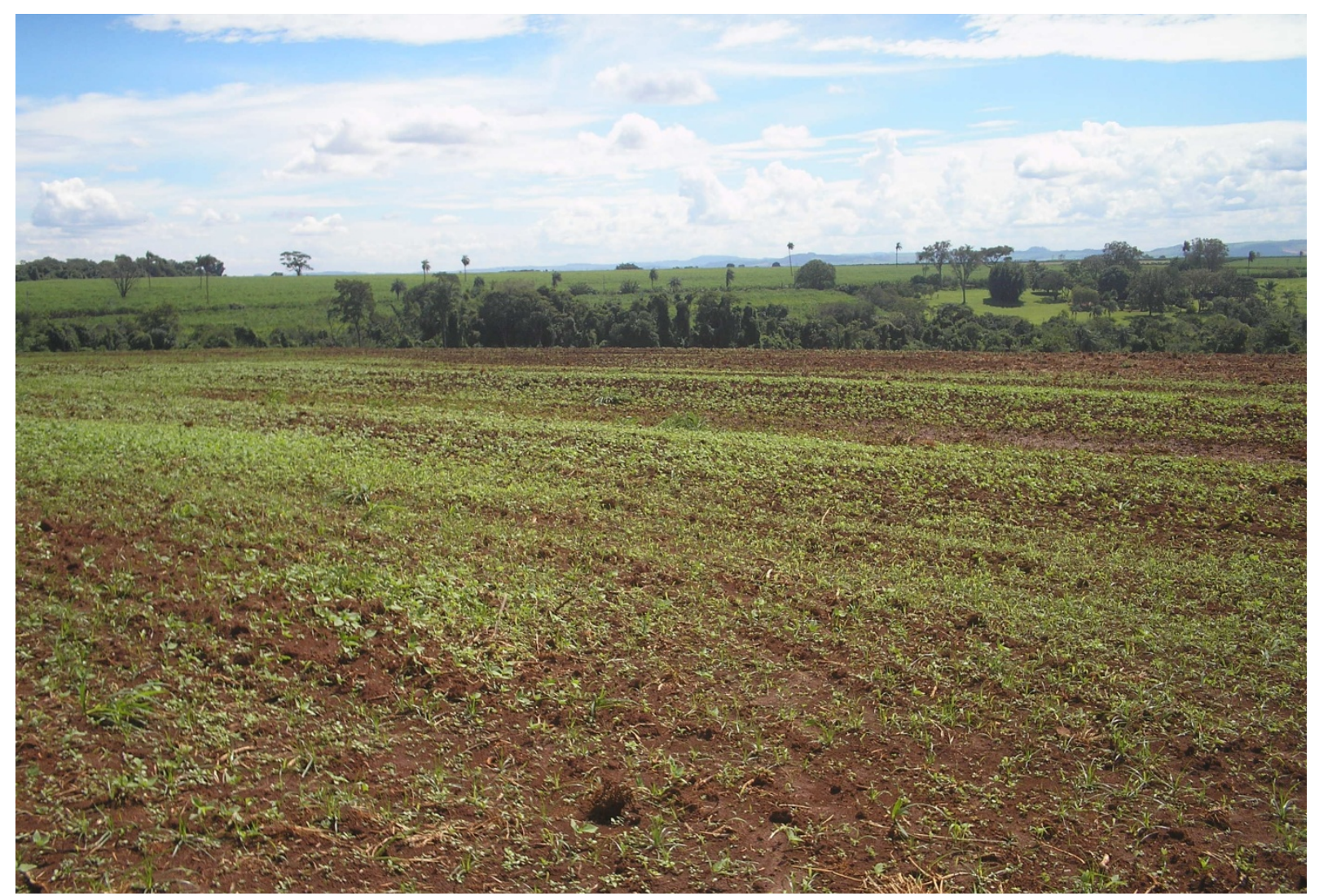

Fonte: Maccann Engenharia SS Ltda.

Figura 33 - Alta infestação de invasoras nas áreas de pastagens - piquete 1 em 20 de março de 2010

Após diagnóstico prescreveu-se a recomendação para o controle químico, conforme quadro 4:

\begin{tabular}{|c|c|c|c|c|c|}
\hline \multirow{2}{*}{ Piquetes } & \multirow{2}{*}{$\begin{array}{c}\text { Área } \\
\text { (ha) }\end{array}$} & \multicolumn{2}{|r|}{ Produtos } & \multirow{2}{*}{$\begin{array}{c}\text { Concentração } \\
(\mathrm{g} / \mathrm{l})\end{array}$} & \multirow{2}{*}{$\begin{array}{l}\text { Dose } \\
\text { (I/ha) }\end{array}$} \\
\hline & & Nome comercial & Princípio ativo & & \\
\hline 1 & 2,00 & GRAZON* $^{*}$ & 2,4-D + PICLORAM & $150+15$ & 2,00 \\
\hline 2 & 2,00 & GRAZON* & 2,4-D + PICLORAM & $150+15$ & 3,00 \\
\hline 3 & 2,00 & TORDON* & 2,4-D + PICLORAM & $240+64$ & 2,00 \\
\hline 4 & 2,00 & DOMINUM* & FLUROXIPIR + AMINOPIRALIDE & $80+40$ & 1,00 \\
\hline 5 & 2,00 & GRAZON* & 2,4-D + PICLORAM & $150+15$ & 2,00 \\
\hline 6 & 2,00 & GRAZON* & 2,4-D + PICLORAM & $150+15$ & 3,00 \\
\hline 7 & 2,00 & TORDON* & 2,4-D + PICLORAM & $240+64$ & 2,00 \\
\hline 8 & 2,00 & DOMINUM* & FLUROXIPIR + AMINOPIRALIDE & $80+40$ & 1,00 \\
\hline
\end{tabular}

Quadro 4 - Recomendação para aplicação de herbicidas nas pastagens

Em 15 de abril de 2010, decidiu-se pela realização de controle químico das ervas invasoras, face o alto grau de infestação e elevado estágio de crescimento das invasoras (Figura 34). 


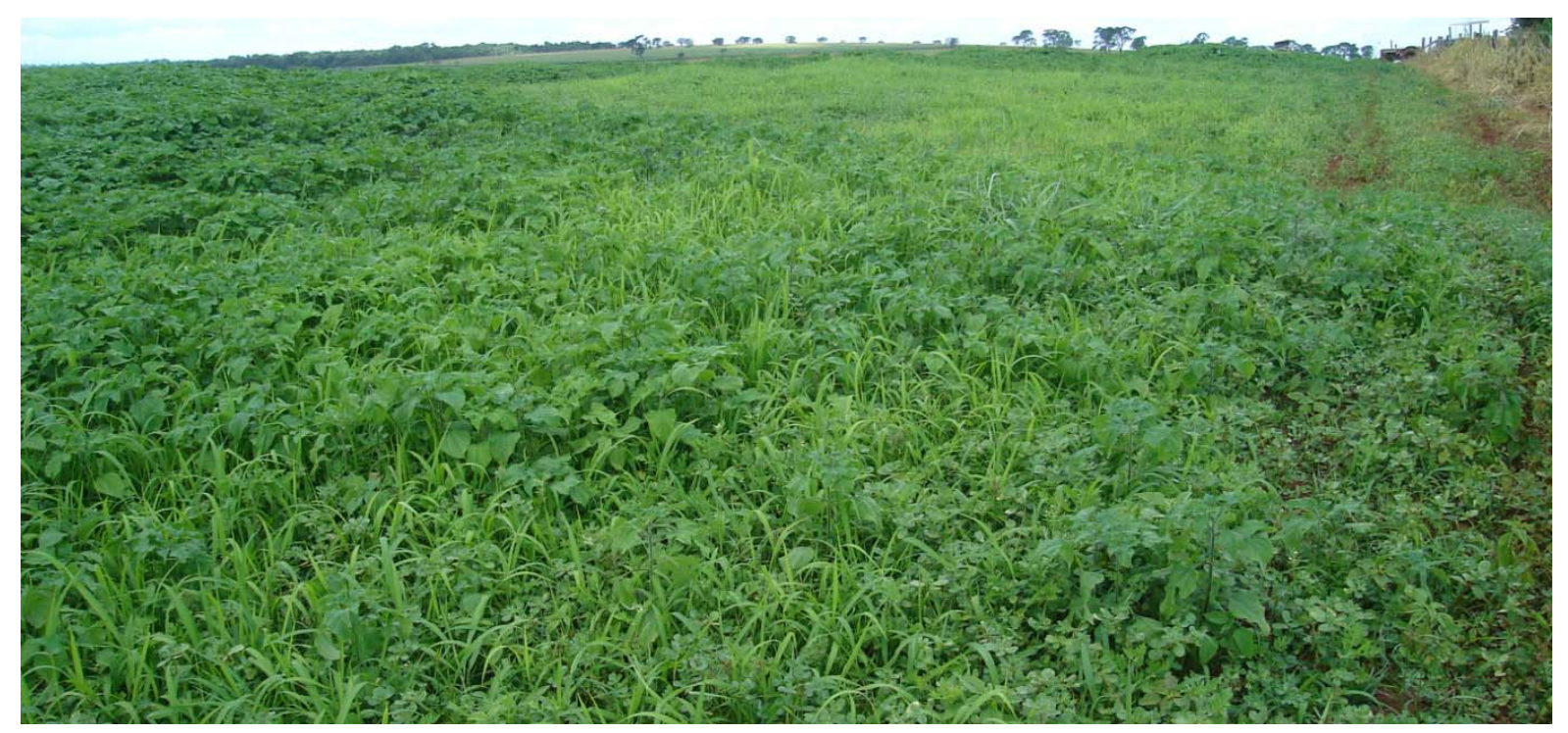

Fonte: Maccann Engenharia SS Ltda.

Figura 34 - Alta infestação de invasoras nas áreas de pastagens - piquete 1 em 15 de abril de 2010

Foram utilizados para tanto os equipamentos agrícolas identificados na figura 22, a saber: (i) trator de pneus de $75 \mathrm{cv}$ de potência e pulverizador com capacidade de 2000 I de calda e pontas modelo teejet API-110-02. A recomendação foi efetuada pelo Eng ${ }^{\circ}$ Agrônomo Rinaldo Rodrigues - CREA 0605018370.

Em 22 de abril de 2010, conforme apresenta a figura 35, comparativamente à situação inicial apresentada na figura 35 , nota-se o efeito fitotóxico promovido pela ação dos herbicidas.

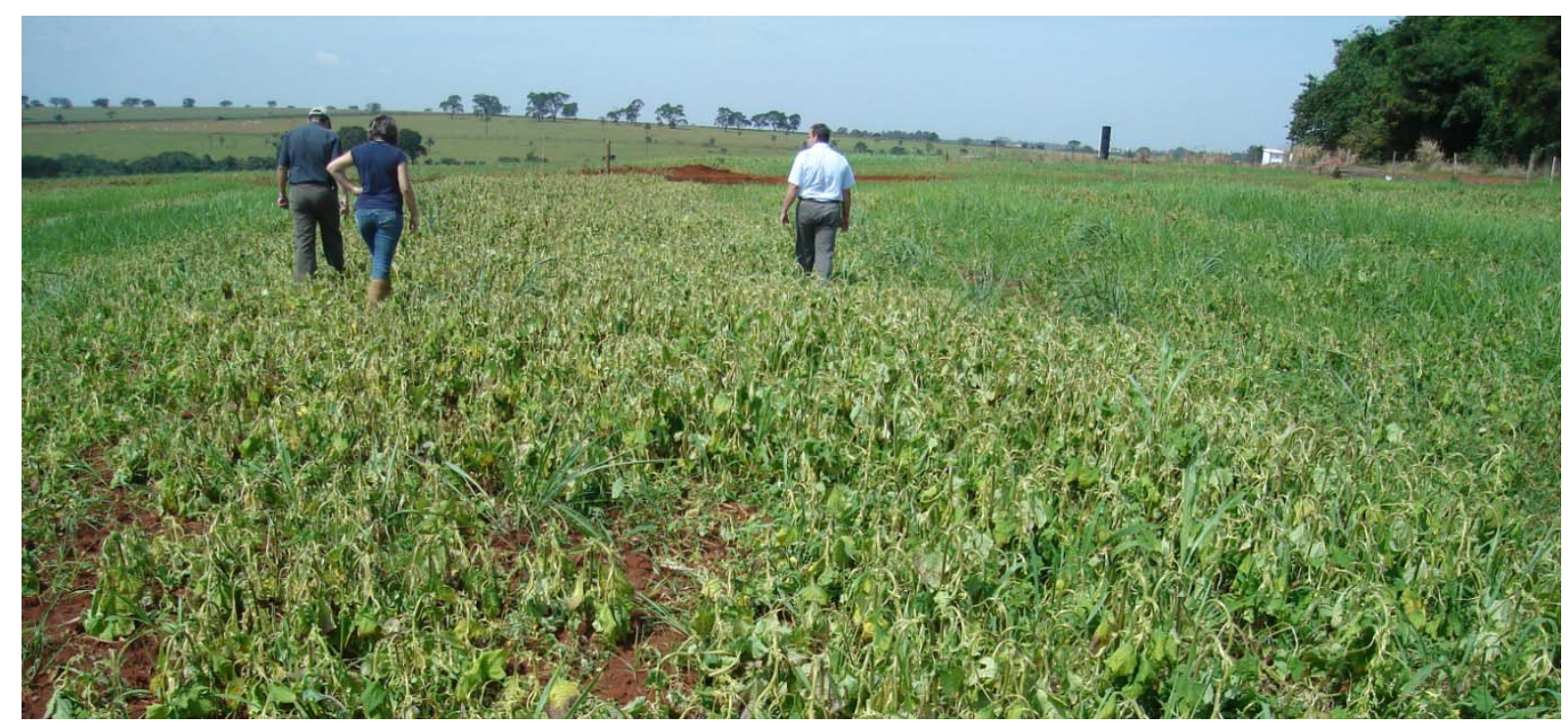

Fonte: Maccann Engenharia SS Ltda.

Figura 35 - Efeito fitotóxico apresentado pelas invasoras 07 dias após aplicação dos herbicidas - piquete 1 
Em 05 de maio de 2010, conforme apresenta a figura 36, o piquete encontrava-se livre de plantas invasoras. O objetivo da aplicação dos herbicidas foi alcançado com sucesso.

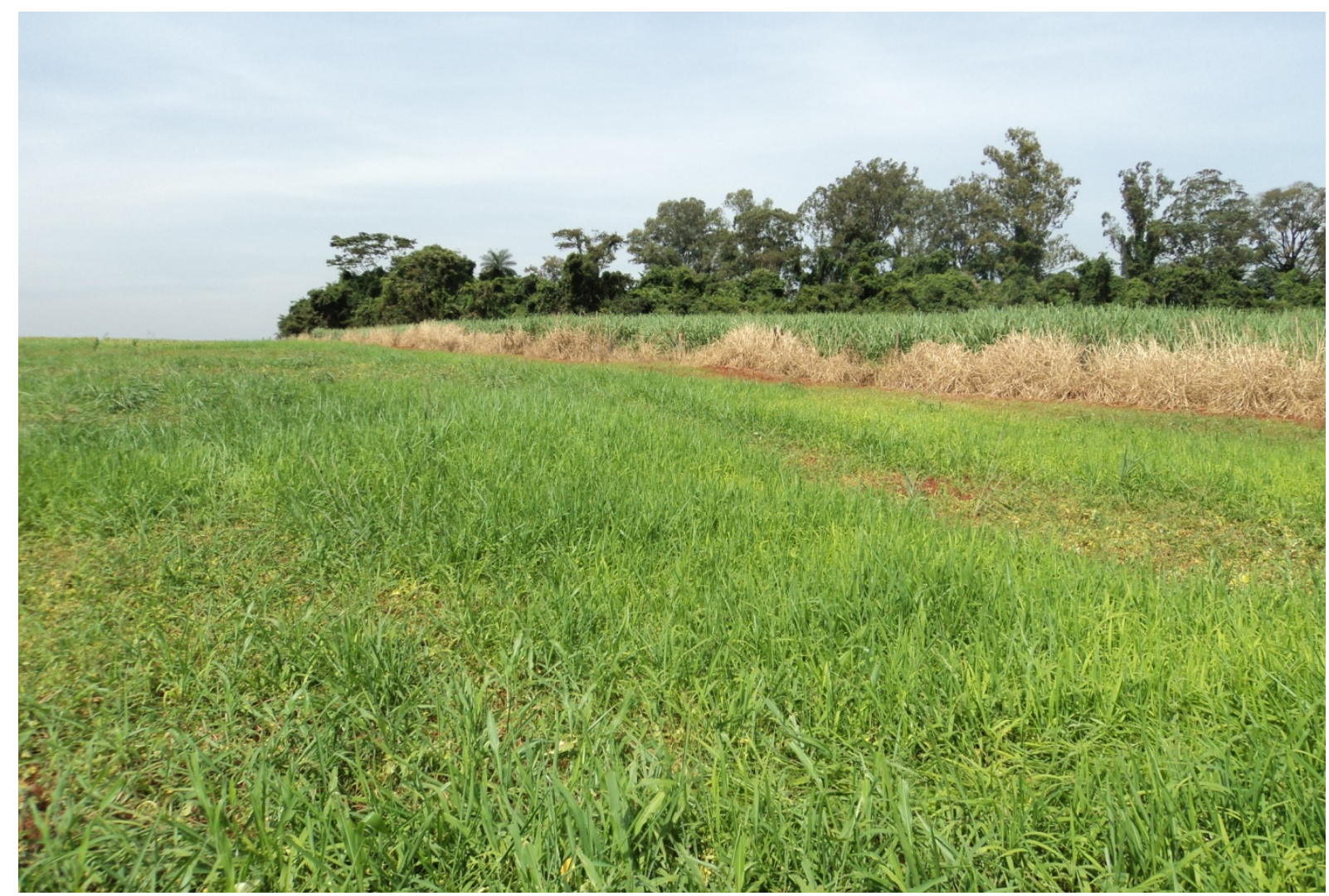

Fonte: Maccann Engenharia SS Ltda.

Figura 36 - Aspecto da forrageira instalada 20 dias após aplicação dos herbicidas - piquete 1

Finalizou-se a implantação das pastagens destinadas à alimentação dos animais no sistema. Todos os serviços realizados para o controle das invasoras foram terceirizados e incorreram em desembolsos.

Para a manutenção das pastagens, projetou-se um fluxo de caixa de 30 anos - 2009 até 2038, sendo o ano de 2009 considerado como ano 1 do projeto e o ano de 2038 o ano 30 - as práticas a serem executadas no horizonte temporal da análise foram: (i) Correção do solo e adubações nitrogenadas em cobertura como prescreveu Paniago (2002) e demais tratos culturais, conforme apresentado no apêndice G.

Concomitantemente às ações descritas anteriormente foram executadas as cercas: (i) das divisas da gleba; (ii) das divisões de piquetes; (iii) da área destinada ao plantio da cana de açúcar; (iv) dos corredores destinados à movimentação dos 
animais entre piquetes; (v) da área destinada ao manejo e confinamento; (vi) da área de reserva; (vii) e para delimitação do acesso até a área destinada ao centro de manejo e instalações de confinamento. Foram executados 3.513,00 metros lineares de cercas, sendo que os serviços de execução destas ficaram a cargo de terceiros. As cercas foram executadas em arame farpado, conforme descreve Videira (2010) e devidamente locadas de acordo com projeto de implantação, conforme apresentado na figura 18. A locação dos pontos foi executada com equipamento de medição denominado Estação Total, marca Topcon, modelo GTS 213, com precisão angular de cinco segundos (Figura 16), por equipe terceirizada.

Finalizada a implantação da cana de açúcar e das pastagens procedeu-se à operação de terraplenagem na área destinadas às edificações e instalações do confinamento de animais. Para tanto se utilizou as informações contidas no projeto de implantação conforme apresentado no anexo D.

(vii) Sistematização da área destinada às edificações e instalações do confinamento

A locação da área, das cotas de escavação para a execução da terraplenagem foi realizada por empresa terceirizada e com auxilio de equipamentos e equipe de topografia, conforme apresentado na figura 16, a saber: Estação Total, marca Topcon, modelo GTS 213, com precisão angular de cinco segundos.

As operações de sistematização do terreno foram executadas com a utilização de: (i) pá-carregadeira de rodas compacta, marca Caterpillar - modelo 924F; (ii) motoniveladora, marca Caterpillar - modelo 12F; (iii) rolo compactador vibratório, marca Bomag - modelo BW 177PDHC e (iv) caminhão de pneus com caçamba basculante, marca Chevrolet - modelo D60.

Inicialmente foi executada limpeza do terreno para eliminação do material orgânico - restos de cultura e vegetação - que poderia prejudicar a estabilização e compactação do terreno. Na operação foi utilizada a pá-carregadeira e o caminhão basculante de pneus (Figura 37) O material retirado foi depositado em área do campus, destinada para tal. 


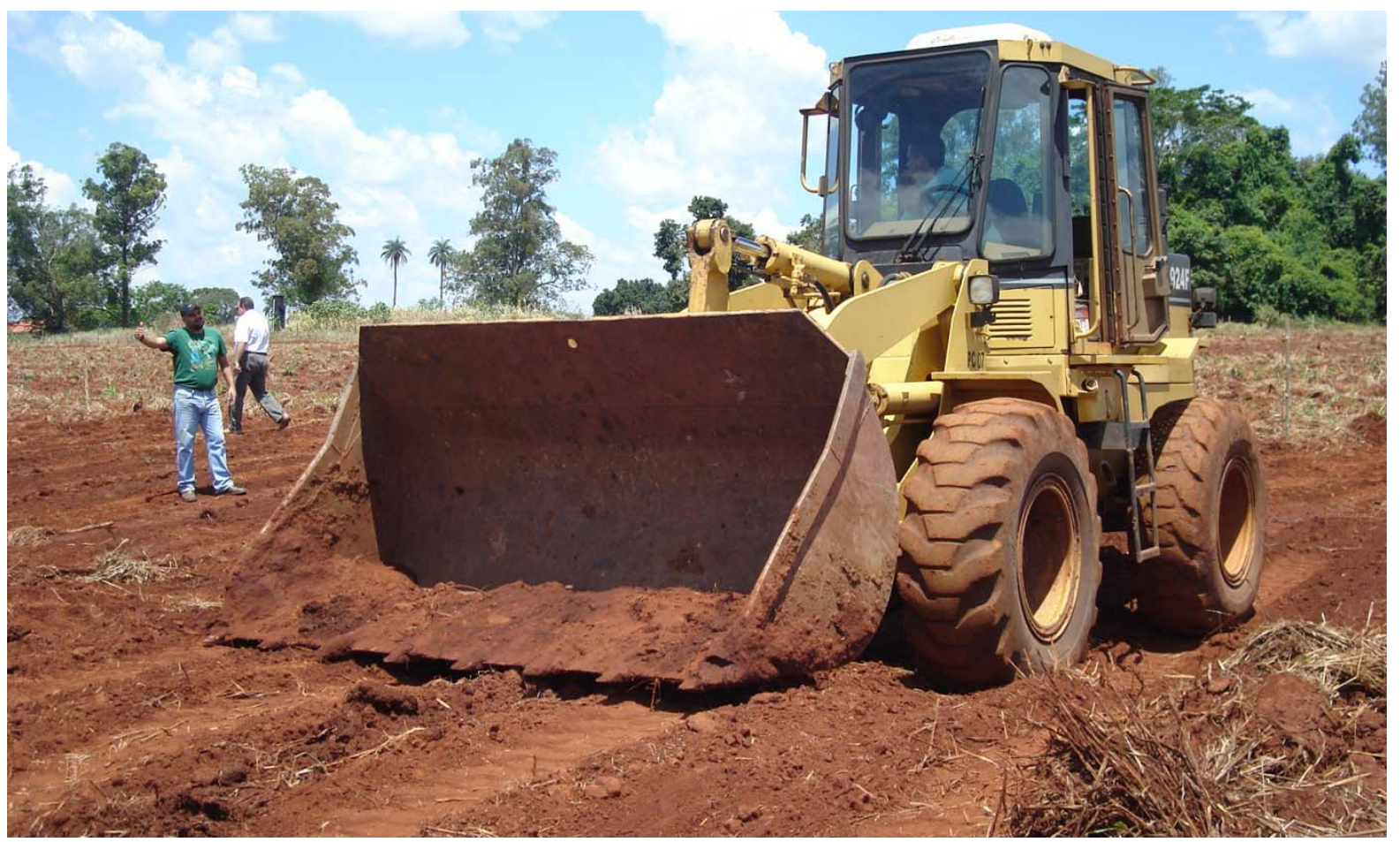

Fonte: Maccann Engenharia SS Ltda.

Figura 37 - Limpeza do terreno

Após a limpeza do terreno executou-se o corte e rebaixamento do terreno até o rebatimento total da área de corte. Utilizou-se para tanto a pá-carregadeira e a motoniveladora (Figura 38).

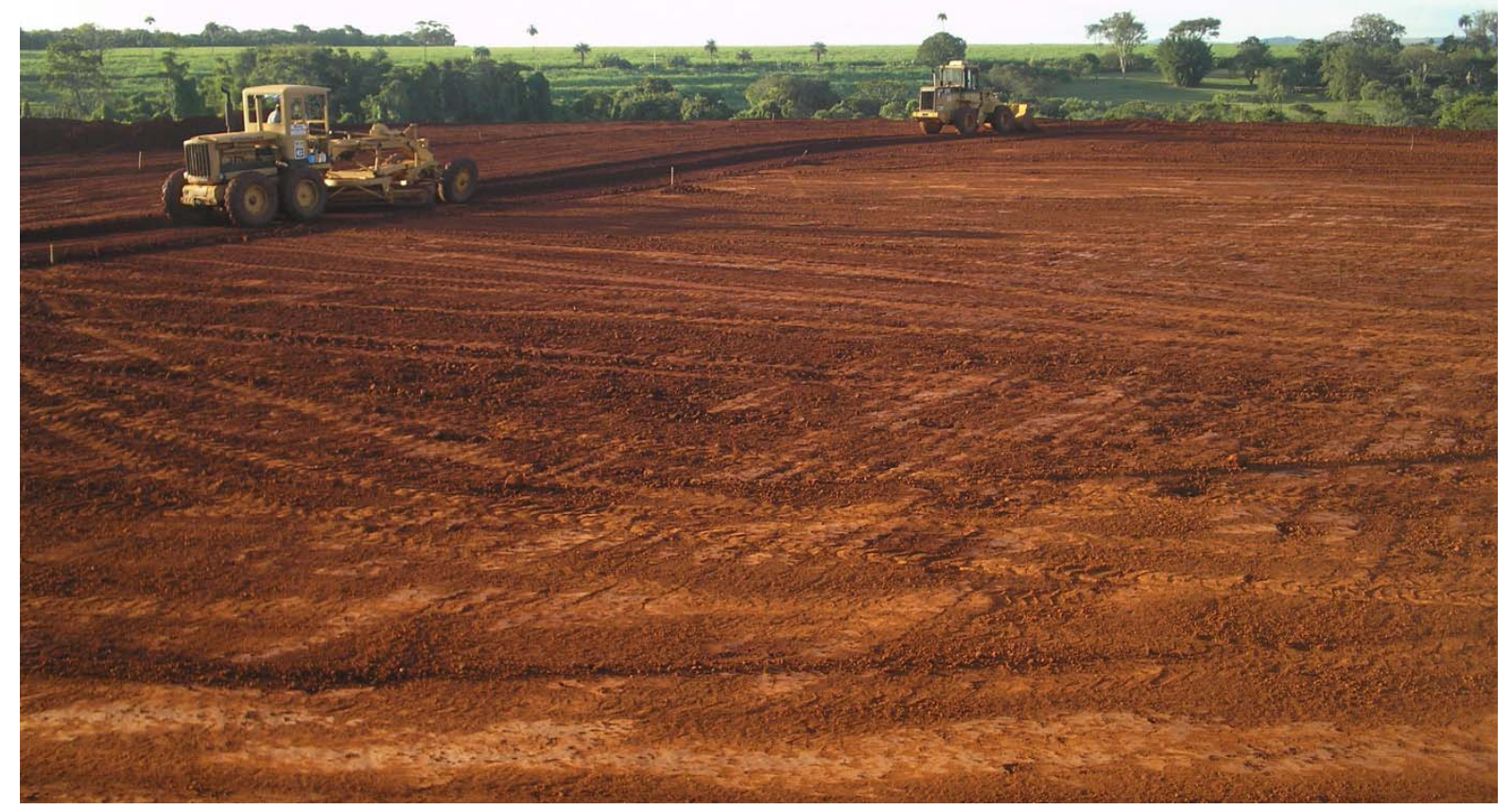

Fonte: Maccann Engenharia SS Ltda.

Figura 38 - Corte e regularização das cotas de projeto 
A movimentação de terra na área de implantação corte foi realizada com a utilização do caminhão de pneus com caçamba basculante (Figura 39).

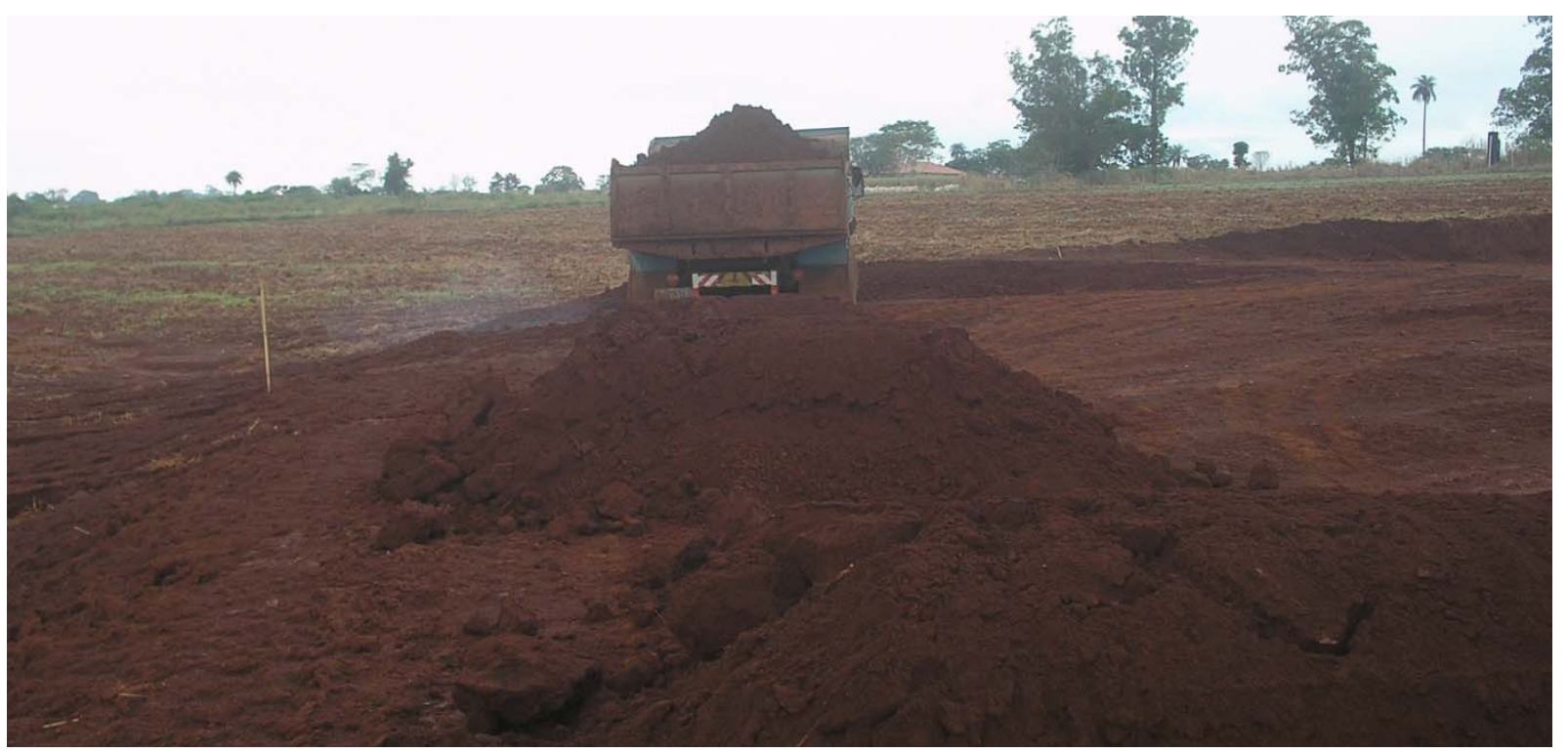

Fonte: Maccann Engenharia SS Ltda.

Figura 39 - Movimentação de terra na área de implantação do confinamento

Regularmente, foram realizados ajustes das cotas de corte do terreno para escoamento das águas pluviais. A declividade determinada foi de $1 \%$ do meio para as extremidades da área útil de corte (Figura 40)

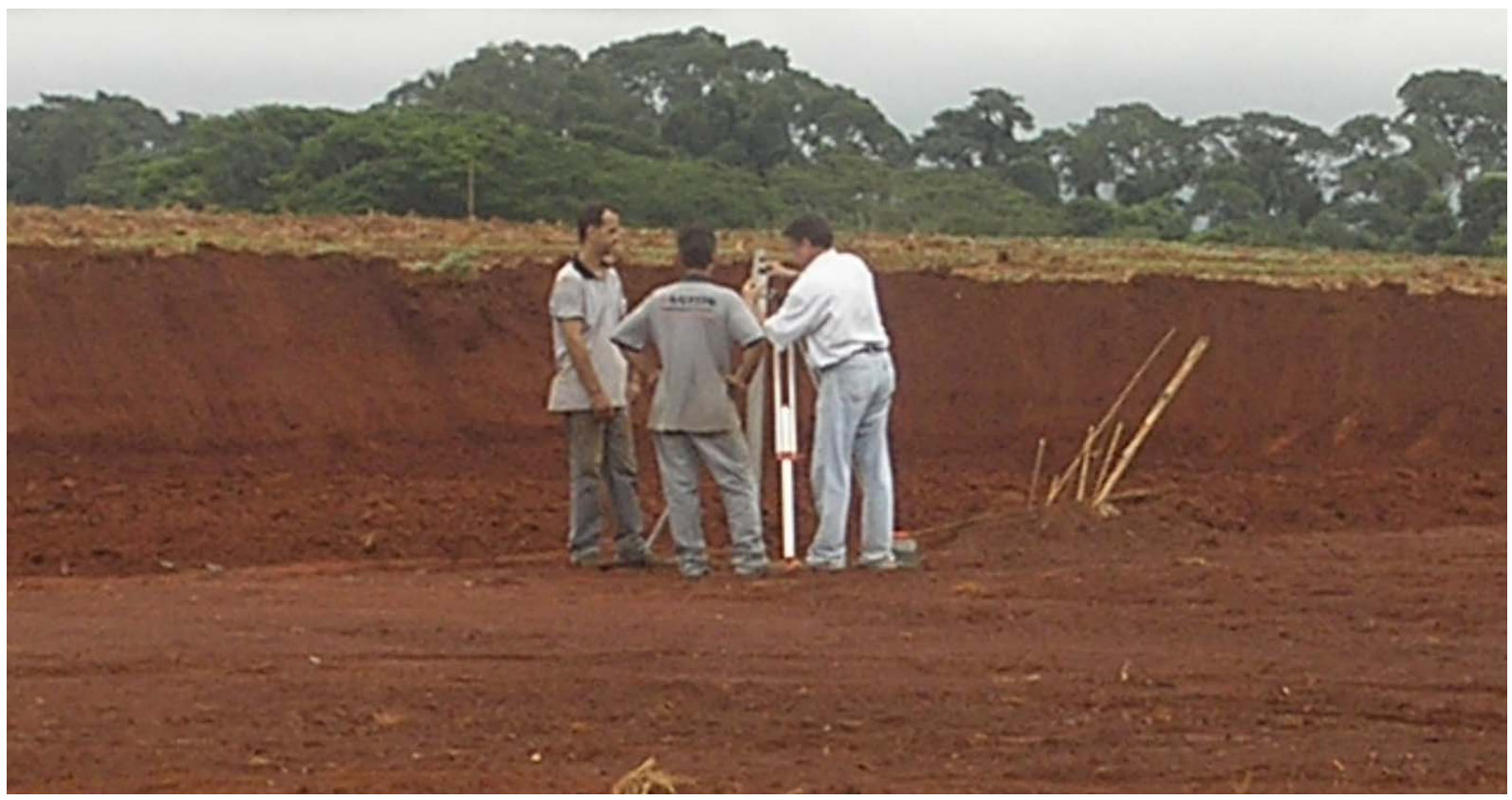

Fonte: Maccann Engenharia SS Ltda.

Figura 40 - Medição para o ajuste de cotas de corte 
Simultaneamente executou-se a compactação da área com a utilização do rolo compactador vibratório, com a finalidade de estabilização das áreas de corte e dos taludes (Figura 41).

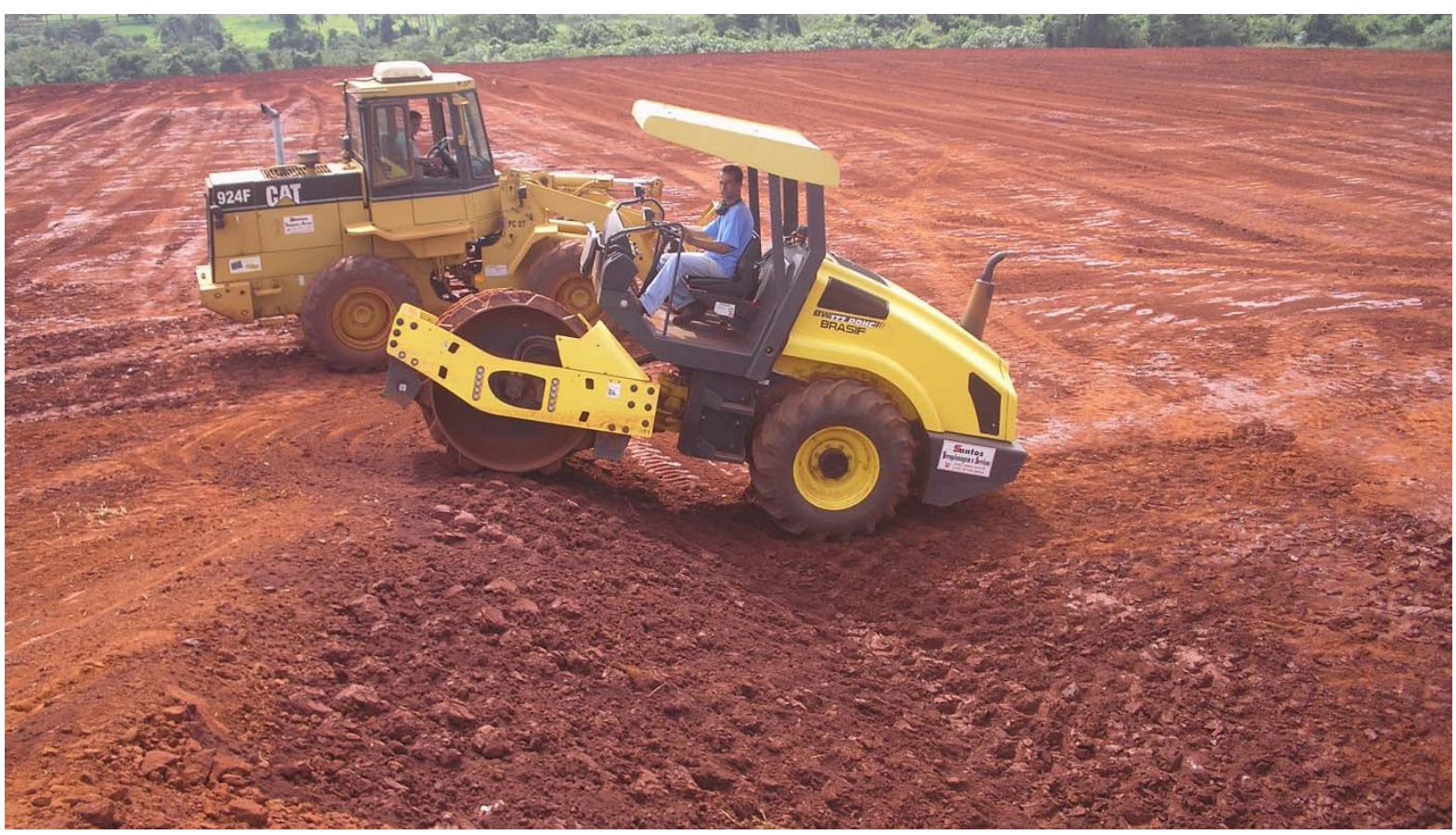

Fonte: Maccann Engenharia SS Ltda.

Figura 41 - Execução do ajuste de cotas de corte

As operações de sistematização foram iniciadas no mês de março de 2010 e finalizadas no mês de abril do mesmo ano. Todas as operações de sistematização foram executadas por empresa terceirizadas.

Finalizou-se desta forma as operações mecanizadas e partiu-se para a execução dos projetos das edificações e instalações. Observa-se que neste ponto as informações lançadas nos fluxos de caixa do empreendimento foram baseadas em orçamentos e contratação prévias de produtos e serviços.

(viii) Projetos de engenharia

Os projetos das instalações e edificações foram elaborados pela Maccann Engenharia SS Ltda., em conformidade com as diretrizes de aprovações da Universidade de São Paulo e devidamente protocolizados junto à Prefeitura do Campus de Pirassununga. O caderno de encargos foi composto de: (i) Planta de Localização; (ii) Projeto de Topografia; (iii) Projeto de Layout e Implantação; (iv) 
Projeto das Instalações; (v) Planta de detalhes dos projetos das instalações; (vi) Distribuição e caminhamento dos ramais elétricos e hidráulicos ; (vii) Projeto de Luminotécnica, Lógica e Conectividade. 
APÊNDICE C - Caracterização do sistema de produção

A caracterização do sistema de produção diz respeito às tecnologias de produção definidas para o sistema. Para a definição das tecnologias de produção utilizou-se a descrição utilizada anteriormente na revisão da literatura (Rodrigues et al., 2010).

Para facilitar o entendimento do processo produtivo e após, a construção dos fluxos de caixa do empreendimento descreveu-se - anualmente - a metodologia de acordo com a evolução do rebanho no sistema, visto que - em termos de fornecimento de animais - este pretendeu ser autossustentável principalmente a partir da sua estabilização. Evidencia-se que o tempo verbal das ações e práticas descritas encontra no passado, por terem sido estas projetadas para lançamento contábil nos fluxos de caixa futuros do empreendimento. A evolução do rebanho foi determinada a partir de indicadores técnicos descritos para os anos considerados nas tabelas.

Adquiriu-se - no início do mês de setembro de 2010 - 100 matrizes da raça Nelore, com peso vivo médio de $450 \mathrm{~kg}$, conforme apresentado na tabela 25 :

Tabela 25 - Evolução do rebanho em número de animais - 2010

\begin{tabular}{|c|c|c|c|c|c|c|c|c|c|c|c|c|}
\hline \multirow[b]{2}{*}{ Rebanho } & \multicolumn{12}{|c|}{2010} \\
\hline & jan. & fev. & mar. & abr. & maio & jun. & jul. & ago. & set. & out. & nov. & dez. \\
\hline Fêmeas > 36 meses & - & - & - & - & - & - & - & - & 100 & 100 & 100 & 100 \\
\hline Fêmeas 24 a 36 meses & - & - & - & - & - & - & - & - & - & - & - & - \\
\hline Fêmeas 12 a 24 meses & - & - & - & - & - & - & - & - & - & - & - & - \\
\hline Fêmeas 0 a 12 meses & - & - & - & - & - & - & - & - & - & - & - & - \\
\hline Machos > 36 meses & - & - & - & - & - & - & - & - & - & - & - & - \\
\hline Machos 24 a 36 meses & - & - & - & - & - & - & - & - & - & - & - & - \\
\hline Machos 12 a 24 meses & - & - & - & - & - & - & - & - & - & - & - & - \\
\hline Machos 0 a 12 meses & - & - & - & - & - & - & - & - & - & - & - & - \\
\hline
\end{tabular}

Para a aquisição realizou-se previamente exames laboratoriais para identificação de animais livres da bactéria Brucella abortus ${ }^{51}$. Após, os animais foram

\footnotetext{
${ }^{51}$ A Brucella abortus é uma bactéria que causa a doença denominada brucelose. Esta doença é amplamente disseminada no rebanho e ocasiona aborto - nas vacas - por volta do terço final da gestação e retenção de placenta.
} 
introduzidos nos piquetes de pastejo com fornecimento de suplementação mineral ad libitum.

No mês de novembro de 2010 foram realizados os protocolos sanitários profiláticos $^{52}$, , conforme detalhamento no apêndice $C$.

O início do período reprodutivo deu-se no dia 01 de dezembro de 2010 e estenderam-se por exatos 45 dias. A estratégia utilizada na reprodução foi a de inseminação artificial em tempo fixo (IATF), com a utilização de dois protocolos. Finalizou-se desta forma a projeção do manejo do rebanho para o ano de 2010.

Para o ano de 2011 (Tabela 26) encerrou-se o período reprodutivo em 15 de janeiro e no início do mês de março realizou-se o diagnóstico de gestação nas matrizes. O índice de prenhes projetado foi de $90 \%$ sendo as matrizes

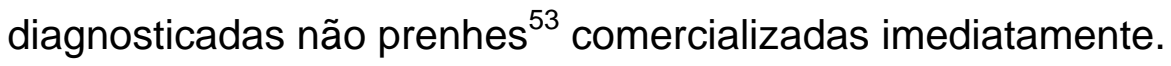

A partir do mês de março os animais continuaram sobsistema de pastejo, porém com a diminuição da oferta de forrageira - devido ao consumo nos meses anteriores e com o inicio da estação das secas ${ }^{54}$ - utilizou-se o fornecimento de suplementação alimentar a base de cana de açúcar. A suplementação mineral do rebanho continuou sendo fornecida ad libitum.

Tabela 26 - Evolução do rebanho em número de animais - 2011

\begin{tabular}{|c|c|c|c|c|c|c|c|c|c|c|c|c|}
\hline \multirow[b]{2}{*}{ Rebanho } & \multicolumn{12}{|c|}{2011} \\
\hline & jan. & fev. & mar. & abr. & maio & jun. & jul. & ago. & set. & out. & nov. & dez. \\
\hline Fêmeas > 36 meses & 100 & 100 & 90 & 90 & 90 & 90 & 90 & 90 & 90 & 90 & 111 & 111 \\
\hline Fêmeas 24 a 36 meses & - & - & - & - & - & - & - & - & - & - & - & - \\
\hline Fêmeas 12 a 24 meses & - & - & - & - & - & - & - & - & - & - & - & - \\
\hline Fêmeas 0 a 12 meses & - & - & - & - & - & - & - & - & 23 & 23 & 45 & 45 \\
\hline Machos > 36 meses & - & - & - & - & - & - & - & - & - & - & - & - \\
\hline Machos 24 a 36 meses & - & - & - & - & - & - & - & - & - & - & - & - \\
\hline Machos 12 a 24 meses & - & - & - & - & - & - & - & - & - & - & - & - \\
\hline Machos 0 a 12 meses & - & - & - & - & - & - & - & - & 23 & 23 & 45 & 45 \\
\hline
\end{tabular}

No início do mês de maio de 2011 procedeu-se à primeira etapa de vacinação dos animais. As vacinas e medicamentos administrados foram idênticos ao manejo sanitário realizado no mês de novembro do ano de 2010.

\footnotetext{
${ }^{52}$ Protocolo oficial e protocolo específico.

53 Dez matrizes foram diagnosticadas não prenhes.

54 Definas nos meses de março, abril, maio, junho, julho, agosto e setembro.
} 
Em meados do mês de setembro de 2011 iniciou-se o período de nascimento de animais que se estendeu até o mês de outubro. O índice de natalidade projetado foi de $90 \%$.

No início do mês de novembro de 2011 procedeu-se à segunda etapa de vacinação do rebanho. Os parâmetros utilizados foram os mesmos realizados na primeira etapa do mesmo ano.

Ainda no mês de novembro foram adquiridas 21 fêmeas - segundo os mesmos critérios da aquisição realizada no mês de setembro de 2010 - que somadas com as 90 fêmeas existente entraram em estação de reprodução em 01 de dezembro de 2011.

No mês de dezembro de 2011 realizou-se a vacina contra a brucelose bovina nas fêmeas nascidas ${ }^{55}$ a partir do mês de setembro do ano em questão.

Finalizou-se assim a projeção do manejo do rebanho para o ano de 2011.

Para o ano de 2012 os manejos: reprodutivo, alimentar e sanitário permaneceram idênticos ao ano de 2011, bem como os índices reprodutivos e de descarte ${ }^{56}$ de fêmeas não prenhes no mês de março de 2012. Adotou-se um índice de mortalidade de animais da ordem de $1 \%$ e como se observa na tabela 27 , e as fêmeas de categoria de idade de 0 a 12 meses foram desmamadas.

Tabela 27 - Evolução do rebanho em número de animais - 2012

\begin{tabular}{|c|c|c|c|c|c|c|c|c|c|c|c|c|}
\hline \multirow[b]{2}{*}{ Rebanho } & \multicolumn{12}{|c|}{2012} \\
\hline & jan. & fev. & mar. & abr. & maio & jun. & jul. & ago. & set. & out. & nov. & dez \\
\hline Fêmeas > 36 meses & 111 & 111 & 100 & 100 & 100 & 100 & 100 & 100 & 100 & 100 & 100 & 100 \\
\hline Fêmeas 24 a 36 meses & - & - & - & - & - & - & - & - & - & - & - & - \\
\hline Fêmeas 12 a 24 meses & - & - & - & - & - & - & - & - & 44 & 44 & 44 & 44 \\
\hline Fêmeas 0 a 12 meses & 45 & 45 & 45 & 45 & 44 & 44 & 44 & 44 & 25 & 25 & 50 & 50 \\
\hline Machos > 36 meses & - & - & - & - & - & - & - & - & - & - & - & - \\
\hline Machos 24 a 36 meses & - & - & - & - & - & - & - & - & - & - & - & - \\
\hline Machos 12 a 24 meses & - & - & - & - & - & - & - & - & - & - & - & - \\
\hline Machos 0 a 12 meses & 45 & 45 & 45 & 45 & 44 & - & - & - & 25 & 25 & 50 & 50 \\
\hline
\end{tabular}

Neste momento utilizou-se suplementação à pasto para estes animais com a projeção de 750 gramas por dia de expectativa de ganho de peso com o objetivo que estes animais chegarem - no mês de dezembro de 2012 - com 360 kg de peso

\footnotetext{
${ }^{55}$ A vacinação contra a brucelose bovina deve ser realizada nas fêmeas entre 03 e 08 meses de idade.

${ }^{56}$ Os animais descartados foram em número de 11 e imediatamente comercializados.
} 
vivo e desta forma serem incorporados ao rebanho de matrizes aptas à reprodução. A evolução destas fêmeas ocorreu no mês de setembro de 2012 e foram classificadas como fêmeas de 12 a 24 meses de idade. Nota-se ainda que 44 machos de classificação de 0 a 12 meses foram enviados - no mês de maio - para o confinamento - com a expectativa de ganho diário de peso de 750 gramas para serem abatidos no mês de dezembro de 2011 - assunto que será tratado mais a frente. Finalizou-se desta forma a projeção do manejo e a evolução do rebanho para o ano de 2012.

Para o ano de 2013 repetiu-se todos os procedimentos de manejo do rebanho, conforme o ano de 2012. Ocorreu a evolução do rebanho conforme apresentado na tabela 28.

Tabela 28 - Evolução do rebanho em número de animais - 2013

\begin{tabular}{|c|c|c|c|c|c|c|c|c|c|c|c|c|}
\hline \multirow[b]{2}{*}{ Rebanho } & \multicolumn{12}{|c|}{2013} \\
\hline & jan. & fev. & mar. & abr. & maio & jun. & jul. & ago. & set. & out. & nov. & dez \\
\hline Fêmeas > 36 meses & 100 & 100 & 90 & 90 & 90 & 74 & 74 & 74 & 74 & 74 & 74 & 74 \\
\hline Fêmeas 24 a 36 meses & - & - & - & - & - & - & - & - & 21 & 21 & 21 & 21 \\
\hline Fêmeas 12 a 24 meses & 44 & 44 & 40 & 21 & 21 & 21 & 21 & 21 & 49 & 49 & 49 & 49 \\
\hline Fêmeas 0 a 12 meses & 50 & 50 & 50 & 50 & 49 & 49 & 49 & 49 & 28 & 28 & 55 & 55 \\
\hline Machos $>36$ meses & - & - & - & - & - & - & - & - & - & - & - & - \\
\hline Machos 24 a 36 meses & - & - & - & - & - & - & - & - & - & - & - & - \\
\hline Machos 12 a 24 meses & - & - & - & - & - & - & - & - & - & - & - & - \\
\hline Machos 0 a 12 meses & 50 & 50 & 50 & 50 & 49 & - & - & - & 28 & 28 & 55 & 55 \\
\hline
\end{tabular}

Nota-se que o número de animais descartados - por categoria de idade - e enviados ao abate e ou vendidos para outros produtores aumentou na seguinte forma: 26 fêmeas com mais de 36 meses e 23 fêmeas de 12 a 24 meses de idade. Foram enviados para o confinamento 49 machos desmamados no mês de maio de 2013, com a expectativa de ganho diário de peso de 750 gramas e para serem abatidos no mês de dezembro de 2013 com 360 kg de peso vivo. Finalizou-se desta forma a projeção do manejo e a evolução do rebanho para o ano de 2013.

Continuando a projeção do manejo e evolução do rebanho proporcionou-se para os animais no sistema - para o ano de 2014 - as mesmas práticas de manejos reprodutivo, alimentar e sanitário projetadas para o ano anterior. A evolução e saídas de animais do sistema são apresentadas na tabela 29. 
Tabela 29 - Evolução do rebanho em número de animais - 2014

\begin{tabular}{|c|c|c|c|c|c|c|c|c|c|c|c|c|}
\hline \multirow[b]{2}{*}{ Rebanho } & \multicolumn{12}{|c|}{2014} \\
\hline & jan. & fev. & mar. & abr. & maio & jun. & jul. & ago. & set. & out. & nov. & dez. \\
\hline Fêmeas > 36 meses & 74 & 74 & 67 & 67 & 67 & 67 & 67 & 67 & 86 & 86 & 81 & 81 \\
\hline Fêmeas 24 a 36 meses & 21 & 21 & 19 & 19 & 19 & 19 & 19 & 19 & 14 & 14 & 14 & 14 \\
\hline Fêmeas 12 a 24 meses & 49 & 49 & 44 & 14 & 14 & 14 & 14 & 14 & 54 & 54 & 54 & 54 \\
\hline Fêmeas 0 a 12 meses & 55 & 55 & 55 & 55 & 54 & 54 & 54 & 54 & 25 & 25 & 50 & 50 \\
\hline Machos > 36 meses & - & - & - & - & - & - & - & - & - & - & - & - \\
\hline Machos 24 a 36 meses & - & - & - & - & - & - & - & - & - & - & - & - \\
\hline Machos 12 a 24 meses & - & - & - & - & - & - & - & - & - & - & - & - \\
\hline Machos 0 a 12 meses & 55 & 55 & 55 & 55 & 54 & - & - & - & 25 & 25 & 50 & 50 \\
\hline
\end{tabular}

Observa-se que os animais descartados - por categoria de idade - e enviados ao abate e ou comercializados para outros produtores foram: 12 fêmeas com mais de 36 meses, 2 fêmeas de 24 a 36 meses de idade e 35 fêmeas de categoria entre 12 a 24 meses de idade. Evidencia-se também que 15\% das matrizes classificadas com mais de 36 meses de idade não entram no protocolo de reprodução, pois serão descartadas no mês de março do ano de 2015. Foram enviados para o confinamento de animais 54 machos desmamados no mês de maio de 2014, com a expectativa de ganho diário de peso de 750 gramas e para serem abatidos no mês de dezembro de 2014 com 360 kg de peso vivo. Finalizou-se a projeção do manejo e a evolução do rebanho para o ano de 2014.

O ano de 2015 repetiu-se as práticas de manejo utilizadas no ano de 2014. A tabela 30 apresenta os números relacionados à evolução do rebanho, abate e comercialização dos animais.

Tabela 30 - Evolução do rebanho em número de animais - 2015

\begin{tabular}{|c|c|c|c|c|c|c|c|c|c|c|c|c|}
\hline \multirow[b]{2}{*}{ Rebanho } & \multicolumn{12}{|c|}{2015} \\
\hline & jan. & fev. & mar. & abr. & maio & jun. & jul. & ago. & set. & out. & nov. & dez. \\
\hline Fêmeas > 36 meses & 81 & 81 & 73 & 73 & 73 & 73 & 73 & 73 & 86 & 86 & 81 & 81 \\
\hline Fêmeas 24 a 36 meses & 14 & 14 & 13 & 13 & 13 & 13 & 13 & 13 & 14 & 14 & 14 & 14 \\
\hline Fêmeas 12 a 24 meses & 49 & 49 & 44 & 14 & 14 & 14 & 14 & 14 & 49 & 49 & 49 & 49 \\
\hline Fêmeas 0 a 12 meses & 50 & 50 & 50 & 50 & 49 & 49 & 49 & 49 & 25 & 25 & 50 & 50 \\
\hline Machos $>36$ meses & - & - & - & - & - & - & - & - & - & - & - & - \\
\hline Machos 24 a 36 meses & - & - & - & - & - & - & - & - & - & - & - & - \\
\hline Machos 12 a 24 meses & - & - & - & - & - & - & - & - & - & - & - & - \\
\hline Machos 0 a 12 meses & 50 & 50 & 50 & 50 & 49 & - & - & - & 25 & 25 & 50 & 50 \\
\hline
\end{tabular}


Nota-se que os animais descartados - por categoria de idade - e enviados ao abate e ou comercializados para outros produtores foram: 13 fêmeas com mais de 36 meses, 1 fêmea de 24 a 36 meses de idade e 39 fêmeas de categoria entre 12 a 24 meses de idade. Evidencia-se também que 15\% das matrizes classificadas com mais de 36 meses de idade não entram no protocolo de reprodução, pois serão descartadas no mês de março do ano de 2016. Foram enviados para o confinamento de animais 49 machos desmamados no mês de maio de 2015, com a expectativa de ganho diário de peso de 750 gramas e para serem abatidos no mês de dezembro de 2015 com 360 kg de peso vivo. Finalizou-se a projeção do manejo e a evolução do rebanho para o ano de 2015.

O ano de 2016 é aquele - que pelas projeções realizadas - o rebanho se estabilizou. A tabela 31 apresenta a evolução do rebanho e os números relacionados à venda, ao envio de animais para o confinamento e à comercialização de animais para outros produtores.

Tabela 31 - Evolução do rebanho em número de animais - 2016

\begin{tabular}{lcccccccccccc}
\hline & \multicolumn{10}{c}{2016} \\
\cline { 2 - 12 } Rebanho & jan. & fev. & mar. & abr. & maio & jun. & jul. & ago. & set. & out. & nov. & dez. \\
\hline Fêmeas > 36 meses & 81 & 81 & 73 & 73 & 73 & 73 & 73 & 73 & 86 & 86 & 81 & 81 \\
Fêmeas 24 a 36 meses & 14 & 14 & 13 & 13 & 13 & 13 & 13 & 13 & 14 & 14 & 14 & 14 \\
Fêmeas 12 a 24 meses & 49 & 49 & 44 & 14 & 14 & 14 & 14 & 14 & 49 & 49 & 49 & 49 \\
Fêmeas 0 a 12 meses & 50 & 50 & 50 & 50 & 49 & 49 & 49 & 49 & 25 & 25 & 50 & 50 \\
\hline Machos > 36 meses & - & - & - & - & - & - & - & - & - & - & - & - \\
Machos 24 a 36 meses & - & - & - & - & - & - & - & - & - & - & - & - \\
Machos 12 a 24 meses & - & - & - & - & - & - & - & - & - & - & - & - \\
Machos 0 a 12 meses & 50 & 50 & 50 & 50 & 49 & - & - & - & 25 & 25 & 50 & 50 \\
\hline
\end{tabular}

Neste ano repetiram-se as práticas de manejo utilizadas no ano de 2015. A variação de animais deveu-se: à venda de 13 fêmeas com mais de 36 meses, 1 fêmea de 24 a 36 meses de idade e 35 fêmeas de categoria entre 12 a 24 meses. Foram enviados para o confinamento de animais 49 machos desmamados no mês de maio de 2016, com a expectativa de ganho diário de peso de 750 gramas e para serem abatidos no mês de dezembro de 2016 com 360 kg de peso vivo. Finalizou-se a projeção do manejo e a evolução do rebanho para o ano de 2016.

A partir do ano calendário 2017- para efeito dos lançamentos monetários nos fluxos de caixa utilizar-se-ão as informações da tabela 30. 
Um aspecto que precisa ser esclarecido foi o critério para a saída - via comercialização para abate ou para outros produtores - dos animais do sistema. Este deveu-se à capacidade de suporte ${ }^{57}$ das pastagens que pode variar de acordo em função da fertilidade do solo, clima, estação do ano e espécie e cultivar das pastagens, além do desempenho animal esperado no sistema de pastejo. Para o cálculo $^{58}$ da unidade animal utilizou-se: $450 \mathrm{~kg}$ de peso vivo para os animais com mais de 36 meses de idade, $410 \mathrm{~kg}$ de peso vivo para os animais com idade entre 24 a 36 meses, $280 \mathrm{~kg}$ de peso vivo para animais entre 12 a 24 meses de idade e $200 \mathrm{~kg}$ de peso vivo para os animais com idade entre 0 a 12 meses. Desta forma 0 valor da unidade animal para os animais - de acordo com a classificação de idade foi de: (i) 1 ; (ii) 0,91 ; (iii) 0,62 ; e (iv) 0,44 . Evidencia-se que somente os animais desmamados foram utilizados no cálculo do total de unidades animais total do rebanho. A tabela 32 apresenta o total das unidades animais no sistema de pastejo por mês dentro do ano de análise.

Tabela 32 - Total de unidades animais distribuídas mensalmente no sistema de pastejo 2010-2017

\begin{tabular}{|c|c|c|c|c|c|c|c|c|c|c|c|c|}
\hline \multirow[b]{2}{*}{ Ano } & \multicolumn{12}{|c|}{ UNIDADE ANIMAL } \\
\hline & jan. & fev. & mar. & abr. & maio & jun. & jul. & ago. & set. & out. & nov. & dez. \\
\hline 2010 & - & - & - & - & - & - & - & - & 100 & 100 & 100 & 100 \\
\hline 2011 & 100 & 100 & 90 & 90 & 90 & 90 & 90 & 90 & 110 & 110 & 151 & 151 \\
\hline 2012 & 111 & 111 & 100 & 100 & 139 & 119 & 119 & 119 & 149 & 149 & 171 & 171 \\
\hline 2013 & 127 & 127 & 115 & 103 & 146 & 109 & 109 & 109 & 148 & 148 & 172 & 172 \\
\hline 2014 & 123 & 123 & 111 & 93 & 141 & 117 & 117 & 117 & 154 & 154 & 172 & 172 \\
\hline 2015 & 128 & 128 & 115 & 94 & 137 & 115 & 115 & 115 & 152 & 152 & 169 & 169 \\
\hline 2016 & 125 & 125 & 112 & 94 & 137 & 115 & 115 & 115 & 152 & 152 & 169 & 169 \\
\hline 2017 & 125 & 112 & 94 & 137 & 115 & 115 & 115 & 115 & 152 & 152 & 169 & 169 \\
\hline
\end{tabular}

Nota-se que os valores médios anuais nos anos selecionados foram: (i) 33; (ii) 105; (iii) 130; (iv) 132; (v) 133; (vi) 132; e (vii) 132 no período de 2010 até 2017 respectivamente, quando ocorreu a estabilização do rebanho. Desta forma observou-se uma taxa de lotação - para o rebanho estabilizado - de 8,25 U.A. por ha, uma vez que a somatória da área de pastagem do sistema é 16 ha.

\footnotetext{
${ }^{57}$ Capacidade de suporte da pastagem refere-se à quantidade de unidades animais em sistema de pastejo por unidade de área, no caso hectares (ha).

${ }^{58}$ Utilizou-se a média dos pesos do rebanho por faixa de idade.
} 
- Manejo do rebanho sobsistema de pastejo

Para os lançamentos contábeis realizados nos fluxos de caixa do empreendimento dividiu-se o item manejo do rebanho em três grupos, a saber: (i) manejo profilático sanitário, (ii) manejo da alimentação e suplementação e (iii) manejo reprodutivo.

O manejo sanitário planejado foi definido em duas operações: (i) protocolo profilático sanitário oficial e (ii) protocolo profilático sanitário específico.

O manejo sanitário oficial utilizado obedeceu às diretrizes específicas previstas no Programa de Sanidade Animal previsto pela legislação vigente para o Estado de São Paulo e por meio da Coordenadoria de Defesa Agropecuária do Estado de São Paulo - CDA (2010) - que determina: (i) a vacinação contra a febre aftosa $^{59}$ em duas etapas anuais: a primeira a ser realizada no mês de maio e envolvendo animais de 0 a 24 meses de idade e a segunda a ser realizada no mês de novembro para todas as categorias animais e (ii) a vacinação contra a brucelose $^{60}$ nas fêmeas de categoria de 3 a 8 meses de idade. O protocolo profilático sanitário específico definido constitui-se de vacinações contra: (i) Raiva bovina $^{61}$; (ii) Clostridiose $^{62}$; (iii) Everminação ${ }^{63}$ dos animais quando do seu nascimento; (iv) Everminação dos animais adultos; e (v) prevenção de onfalite ${ }^{64}$, conforme Afonso (2003). Os exames para identificação da brucelose bovina utilizaram-se da metodologia de Dias et al. (2009).

O manejo da alimentação e suplementação dos animais deu-se respectivamente por: (i) Suplementação mineral pronta para uso: por meio de fornecimento de suplemento mineral denominado Manafós $80^{65}$ e (ii) Uréia pecuária

\footnotetext{
${ }^{59}$ A febre aftosa é uma doença viral altamente contagiosa que afeta, dentre outros, o gado bovino. $\mathrm{O}$ vírus da FA pertence ao gênero Aphtovirus da família Picornaviridae.

${ }^{60}$ Transmitida pela bactéria Brucella abortus.

${ }^{61}$ A raiva bovina é causada por um vírus RNA envelopada do gênero Lyssavirus do grupo dos Rhabdovírus, que após ser transmitido ao animal se multiplica no local da mordedura, levando a um quadro de encefalite e ganglioneurite.

62 Doenças causadas pelas bactérias do gênero Clostridium, conhecidas como: botulismo, morte súbta, enterotoxemia, carbúnculo sintomático, gangrena gasosa, hemoglobinúria bacilar, hepatite necrótica e tétano.

${ }^{63}$ A everminação tem por objetivo o controle de nematódeos gastrintestinais e pulmonares. Também tem ação bernicida, sarnicida, piolhicida e ajuda no controle do carrapato dos bovinos.

64 Onfalite é o nome que se dá à inflamação do umbigo, caracterizada por edema (inchaço), sensibilidade e aumento de temperatura. O cordão umbilical leva alguns dias para secar, e é nesse período que pode ser uma porta de entrada para muitos micróbios.

${ }^{65}$ Produto comercial da Companhia Nacional de Nutrição Animal. Composição básica: Composição básica: Fosfato Bicálcico Desfluorizado, Cloreto de Sódio (Sal Comum), Carbonato de Cálcio, Enxofre
} 
adicionada ao suplemento mineral, conforme prescreveu Gonçalves et. al (2003) e (iii) Suplementação com cana de açúcar in natura, com a adição de uréia pecuária, farelo de milho e sulfato de amônio, conforme preconizado por Gonçalves (2003).

O protocolo de reprodução utilizado para o planejamento reprodutivo foi o indicado pela PFIZER, INC.(2010).

Admitiu-se para o manejo do rebanho e do empreendimento a contratação de 2 funcionários.

Ventilado (Flor de Enxofre), Óxido de Magnésio, Sulfato Ferroso, Sulfato de Cobre, Óxido de Zinco, Sulfato de Manganês, Aditivo Flavorizante, Sulfato de Cobalto, Iodato de Cálcio, Selenito de Sódio. Níveis de garantia por kg de produto, consultar informações do fabricante. 
APÊNDICE D - Memorial de cálculo para deflacionamento das médias nominais mensais dos preços da arroba de carne bovina e atualização para valores reais equivalentes para o mês de julho de 2010

continua

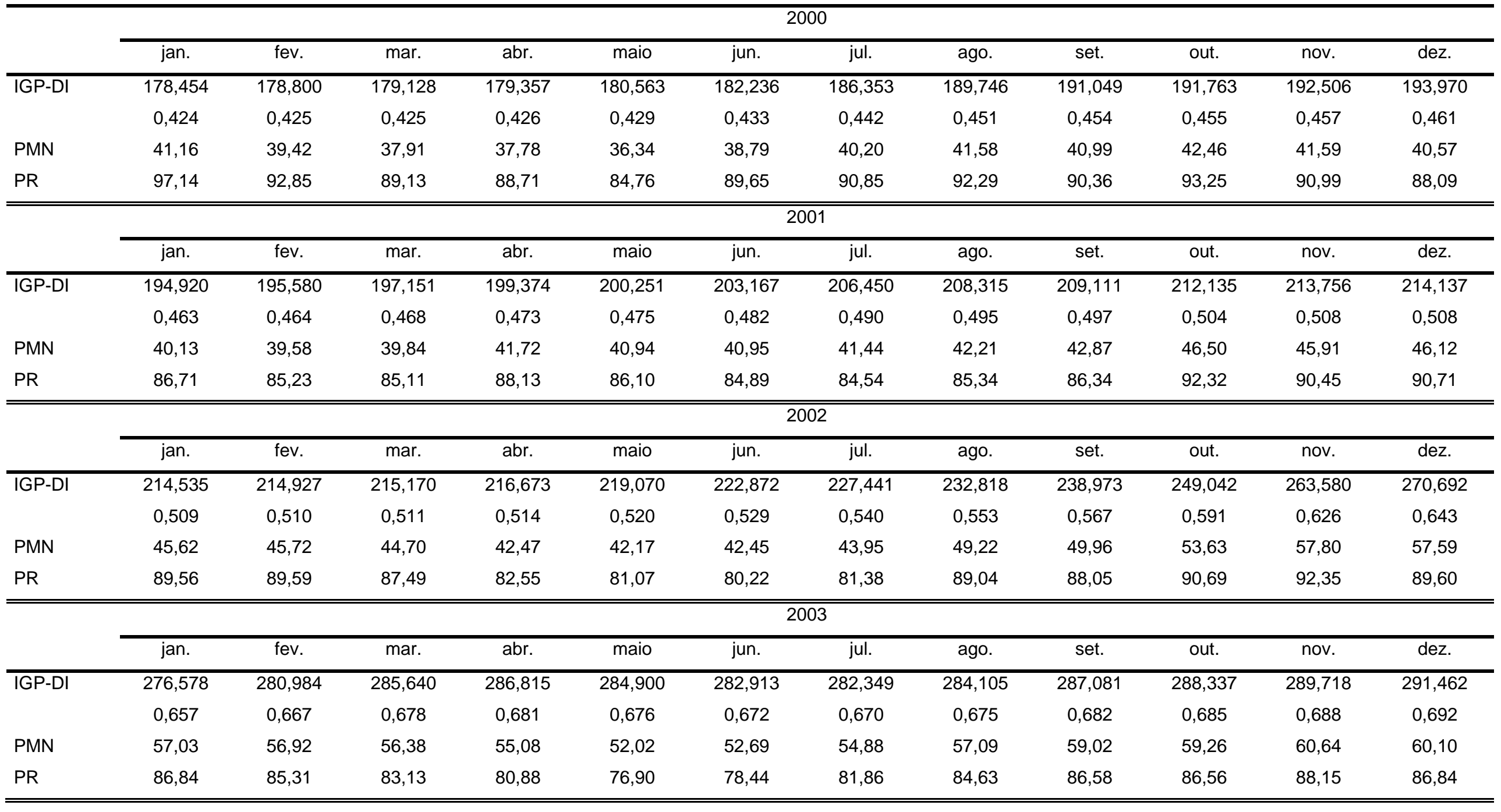


continuação

\begin{tabular}{|c|c|c|c|c|c|c|c|c|c|c|c|c|}
\hline & \multicolumn{12}{|c|}{2004} \\
\hline & jan. & fev. & mar. & abr. & maio & jun. & jul. & ago. & set. & out. & nov. & dez. \\
\hline \multirow[t]{2}{*}{ IGP-DI } & 293,793 & 296,976 & 299,746 & 303,184 & 307,616 & 311,576 & 315,113 & 319,244 & 320,788 & 322,492 & 325,148 & 326,833 \\
\hline & 0,698 & 0,705 & 0,712 & 0,720 & 0,730 & 0,740 & 0,748 & 0,758 & 0,762 & 0,766 & 0,772 & 0,776 \\
\hline PMN & 60,17 & 58,59 & 58,02 & 58,11 & 59,43 & 60,49 & 60,33 & 61,58 & 60,00 & 59,64 & 61,74 & 61,18 \\
\hline \multirow[t]{3}{*}{ PR } & 86,25 & 83,09 & 81,52 & 80,72 & 81,37 & 81,76 & 80,63 & 81,24 & 78,77 & 77,89 & 79,97 & 78,84 \\
\hline & \multicolumn{12}{|c|}{2005} \\
\hline & jan. & fev. & mar. & abr. & maio & jun. & jul. & ago. & set. & out. & nov. & dez. \\
\hline \multirow[t]{2}{*}{ IGP-DI } & 327,915 & 329,241 & 332,490 & 334,170 & 333,321 & 331,823 & 330,484 & 327,887 & 327,454 & 329,529 & 330,619 & 330,835 \\
\hline & 0,779 & 0,782 & 0,789 & 0,793 & 0,791 & 0,788 & 0,785 & 0,779 & 0,778 & 0,782 & 0,785 & 0,786 \\
\hline PMN & 59,56 & 58,23 & 57,18 & 55,40 & 54,23 & 53,78 & 52,61 & 51,30 & 50,02 & 55,47 & 56,01 & 51,74 \\
\hline \multirow[t]{3}{*}{ PR } & 76,50 & 74,49 & 72,43 & 69,82 & 68,52 & 68,26 & 67,04 & 65,89 & 64,33 & 70,89 & 71,35 & 65,87 \\
\hline & \multicolumn{12}{|c|}{2006} \\
\hline & jan. & fev. & mar. & abr. & maio & jun. & jul. & ago. & set. & out. & nov. & dez. \\
\hline \multirow[t]{2}{*}{ IGP-DI } & 333,222 & 333,030 & 331,531 & 331,607 & 332,851 & 335,067 & 335,637 & 337,011 & 337,817 & 340,541 & 342,482 & 343,384 \\
\hline & 0,791 & 0,791 & 0,787 & 0,787 & 0,790 & 0,796 & 0,797 & 0,800 & 0,802 & 0,809 & 0,813 & 0,815 \\
\hline PMN & 49,64 & 50,53 & 49,60 & 50,26 & 48,85 & 48,83 & 50,41 & 55,90 & 59,01 & 61,55 & 55,05 & 53,48 \\
\hline \multirow[t]{3}{*}{ PR } & 62,74 & 63,90 & 63,01 & 63,83 & 61,81 & 61,38 & 63,25 & 69,86 & 73,57 & 76,12 & 67,70 & 65,59 \\
\hline & \multicolumn{12}{|c|}{2007} \\
\hline & jan. & fev. & mar. & abr. & maio & jun. & jul. & ago. & set. & out. & nov. & dez. \\
\hline \multirow[t]{2}{*}{ IGP-DI } & 344,850 & 345,652 & 346,407 & 346,878 & 347,421 & 348,328 & 349,628 & 354,495 & 358,633 & 361,308 & 365,100 & 370,485 \\
\hline & 0,819 & 0,821 & 0,823 & 0,824 & 0,825 & 0,827 & 0,830 & 0,842 & 0,852 & 0,858 & 0,867 & 0,880 \\
\hline PMN & 53,57 & 55,14 & 55,93 & 55,82 & 55,55 & 57,40 & 61,48 & 64,35 & 61,40 & 63,82 & 72,54 & 74,21 \\
\hline PR & 65,42 & 67,18 & 68,00 & 67,77 & 67,34 & 69,40 & 74,06 & 76,45 & 72,10 & 74,39 & 83,68 & 84,36 \\
\hline
\end{tabular}


conclusão

\begin{tabular}{|c|c|c|c|c|c|c|c|c|c|c|c|c|}
\hline & \multicolumn{12}{|c|}{2008} \\
\hline & jan. & fev. & mar. & abr. & maio & jun. & jul. & ago. & set. & out. & nov. & dez. \\
\hline \multirow[t]{2}{*}{ IGP-DI } & 374,139 & 375,558 & 378,194 & 382,414 & 389,585 & 396,954 & 401,406 & 399,870 & 401,327 & 405,707 & 405,982 & 404,185 \\
\hline & 0,888 & 0,892 & 0,898 & 0,908 & 0,925 & 0,943 & 0,953 & 0,949 & 0,953 & 0,963 & 0,964 & 0,960 \\
\hline PMN & 74,61 & 74,85 & 76,19 & 77,24 & 80,52 & 91,53 & 92,79 & 92,05 & 88,82 & 90,79 & 88,39 & 82,20 \\
\hline \multirow[t]{3}{*}{ PR } & 83,99 & 83,94 & 84,84 & 85,06 & 87,04 & 97,11 & 97,35 & 96,95 & 93,21 & 94,25 & 91,69 & 85,65 \\
\hline & \multicolumn{12}{|c|}{2009} \\
\hline & jan. & fev. & mar. & abr. & maio & jun. & jul. & ago. & set. & out. & nov. & dez. \\
\hline \multirow[t]{2}{*}{ IGP-DI } & 404,244 & 403,737 & 400,353 & 400,530 & 401,232 & 399,966 & 397,393 & 397,758 & 398,738 & 398,575 & 398,857 & 398,407 \\
\hline & 0,960 & 0,959 & 0,951 & 0,951 & 0,953 & 0,950 & 0,944 & 0,944 & 0,947 & 0,946 & 0,947 & 0,946 \\
\hline PMN & 84,01 & 81,54 & 77,54 & 80,03 & 79,47 & 80,85 & 81,39 & 77,92 & 77,25 & 77,18 & 74,35 & 74,64 \\
\hline \multirow[t]{3}{*}{ PR } & 87,52 & 85,06 & 81,57 & 84,15 & 83,42 & 85,13 & 86,26 & 82,50 & 81,59 & 81,55 & 78,51 & 78,90 \\
\hline & \multicolumn{12}{|c|}{2010} \\
\hline & jan. & fev. & mar. & abr. & maio & jun. & jul. & ago. & set. & out. & nov. & dez. \\
\hline \multirow[t]{2}{*}{ IGP-DI } & 402,425 & 406,826 & 409,399 & 412,341 & 418,811 & 420,24 & 421,15 & - & - & - & - & - \\
\hline & 0,956 & 0,966 & 0,972 & 0,979 & 0,994 & 0,998 & 1,000 & - & - & - & - & - \\
\hline PMN & 75,70 & 77,03 & 79,03 & 82,33 & 81,48 & 84,14 & 88,67 & - & - & - & - & - \\
\hline PR & 79,22 & 79,74 & 81,30 & 84,09 & 81,94 & 84,32 & 88,67 & - & - & - & - & - \\
\hline
\end{tabular}


APÊNDICE E - Infraestrutura e instalações

continua

\begin{tabular}{|c|c|c|c|c|}
\hline \multirow{2}{*}{ Descrição } & \multirow{2}{*}{ Totais parciais } & & & \multirow{2}{*}{$\begin{array}{l}\$ \\
\text { ANO } 3(2011)\end{array}$} \\
\hline & & ANO 1 (2009) & ANO 2 (2010) & \\
\hline A - Construções & $342.631,27$ & - & $206.053,35$ & $136.577,92$ \\
\hline A1 - Obras civil & $220.372,52$ & - & $138.353,60$ & $82.018,92$ \\
\hline Terraplenagem & $9.000,00$ & - & $9.000,00$ & - \\
\hline Obra civil do confinamento & $34.332,60$ & - & $6.748,60$ & $27.584,00$ \\
\hline Obra civil do escritório e almoxarifado & $37.064,92$ & - & - & $37.064,92$ \\
\hline Obra civil dos currais e centro de manejo & $13.305,00$ & - & $13.305,00$ & - \\
\hline Estrutura metálica do confinamento & $58.000,00$ & - & $58.000,00$ & - \\
\hline Estrutura metálica do escritório e almoxarifado & $17.370,00$ & - & - & $17.0370,00$ \\
\hline Estrutura metálica dos currais e centro de manejo & $48.000,00$ & - & $48.000,00$ & - \\
\hline Projetos e serviços (topografia) & $3.300,00$ & - & $3.330,00$ & - \\
\hline A2 - Layout e equipamentos & $85.721,75$ & $12.435,99$ & $50.337,76$ & $22.948,00$ \\
\hline Cercas e corredores (piquetes) & $23.478,14$ & - & $23.478,14$ & - \\
\hline Formação (cana) & $12.435,99$ & $12.435,99$ & - & - \\
\hline Formação (capim) & $11.859,63$ & - & $11.859,63$ & - \\
\hline Formação (reserva) & $3.000,00$ & - & $3.000,00$ & - \\
\hline Bebedores (piquetes) & $9.688,00$ & - & - & $9.688,00$ \\
\hline Cochos suplementação (piquetes) & $6.000,00$ & - & - & $6.000,00$ \\
\hline Cochos suplementação (confinamento) & $7.260,00$ & - & - & $7.260,00$ \\
\hline Brete de contenção (centro de manejo) & $12.000,00$ & - & $12.000,00$ & - \\
\hline A3 - Equipamentos - Hidráulica e Elétrica & $42.537,00$ & - & $31.611,00$ & \\
\hline Infraestrutura de distribuição hidráulica (rede adutora e ramais) & $10.926,00$ & - & $10.926,00$ & - \\
\hline Infraestrutura de distribuição hidráulica (confinamento) & $5.725,00$ & - & - & $5.725,00$ \\
\hline
\end{tabular}


conclusão

\begin{tabular}{|c|c|c|c|c|}
\hline Infraestrutura e distribuição elétrica & $25.886,00$ & - & - & $25.886,00$ \\
\hline B - Aquisição de animais & $135.858,00$ & - & $109.800,00$ & $26.058,00$ \\
\hline B1 - Animais de produção & $126.858,00$ & - & $109.800,00$ & $23.058,00$ \\
\hline Fêmeas reprodutoras (24 a 36 meses) & $126.585,00$ & - & $109.800,00$ & - \\
\hline B2 - Animais de serviço & $3.000,00$ & - & - & $3.000,00$ \\
\hline Animais de tração (equinos) & $3.000,00$ & - & - & $3.000,00$ \\
\hline
\end{tabular}


APÊNDICE F - Formação, manutenção e reforma da lavoura de cana de açúcar

continua

\begin{tabular}{|c|c|c|c|c|c|c|}
\hline \multirow{2}{*}{ Descrição } & \multirow{2}{*}{ Especificações / Observações } & \multirow{2}{*}{ Coef. } & \multirow{2}{*}{ Unid. } & \multirow{2}{*}{$\begin{array}{l}\text { Unitário } \\
\mathrm{R} \$\end{array}$} & \multicolumn{2}{|c|}{ ANO 1 (2009) } \\
\hline & & & & & Quant. & $\mathrm{R} \$$ \\
\hline A - Operações mecanizadas - terceiros & & & & & & $2.103,51$ \\
\hline A1 - Implantação e manutenção & & & & & - & 941,35 \\
\hline Aplicação herbicida (Dessecação) & Trator 71-90 cv + Implemento & 0,50 & hora/máq & 90,00 & - & - \\
\hline Carregamento de calcário e fertilizante & Trator $71-90 \mathrm{cv}+$ caçamba carregadeira & 0,10 & hora/máq & 60,00 & - & - \\
\hline Aplicação de calcário e fertilizante & Trator $71-90 \mathrm{cv}+$ distribuidor de calcário & 0,50 & hora/máq & 90,00 & - & - \\
\hline Subsolagem & Trator $180 \mathrm{cv}+$ subsolador 3 hastes & 1,50 & hora/máq & 114,00 & - & - \\
\hline Gradagem pesada & Trator $180 \mathrm{cv}+$ grade $16 \times 32 "$ & 1,24 & hora/máq & 108,00 & 3,98 & 533,00 \\
\hline Gradagem intermediária & Trator $180 \mathrm{cv}+$ grade $32 \times 26 "$ & 0,90 & hora/máq & 114,00 & 3,98 & 408,35 \\
\hline Gradagem niveladora & Trator $150 \mathrm{cv}$ + grade $16 \times 24 "$ & 0,70 & hora/máq & 114,00 & - & - \\
\hline Construção de linhas de nível terraceamento & Trator 180 + terraceador $16 \times 28 "$ & 2,20 & hora/máq & 132,00 & - & - \\
\hline Construção de carreadores & Trator 91-110 cv + lâmina & 0,60 & hora/máq & 96,00 & - & - \\
\hline A2 - Implantação (plantio) & & & & & & 764,16 \\
\hline Sulcação / adubação de plantio & Trator $150 \mathrm{cv}+$ sulcador de 02 hastes & 1,60 & hora/máq & 96,00 & 3,98 & 611,33 \\
\hline Distribuição de composto & Trator $91-110 \mathrm{cv}+$ implemento & 1,60 & hora/máq & 60,00 & - & - \\
\hline Cobertura de mudas & Trator $71-90 \mathrm{cv}+$ implemento & 0,80 & hora/máq & 48,00 & 3,98 & 152,83 \\
\hline Carregamento de mudas & Carregadeira & 14,00 & ton/ha & 2,64 & - & - \\
\hline Transporte & Caminhão truck & 14,00 & ton/ha & 15,00 & - & - \\
\hline Reboque & Trator $180 \mathrm{cv}$ & 1,00 & hora/máq & 72,00 & - & - \\
\hline A3 - Tratos culturais & & & & & & 398,00 \\
\hline Aplicação de herbicidas & Trator 71-90 cv + implemento & 0,50 & hora/máq & 100,00 & 3,98 & 199,00 \\
\hline Cultivo duplo & Trator $150 \mathrm{cv}+$ implemento & 0,50 & hora/máq & 100,00 & 3,98 & 199,00 \\
\hline
\end{tabular}


conclusão

B - Operações manuais

$5.091,02$

B1 - Preparo de solo (inicial)

\begin{tabular}{|c|c|c|c|c|c|c|}
\hline Carregamento e aplicação de calcário & 1 homem para 4 hectares & 0,02 & diárias & 40,00 & - & - \\
\hline B2 - Plantio & & & & & & $5.091,02$ \\
\hline Análise de solo & 1 analise anual para cada 4 hectares & 1,00 & $\mathrm{vb}$ & 100,00 & - & - \\
\hline Plantio manual (equipe) & Diária da equipe de plantio por hectare & 1,00 & diárias & $1.279,15$ & 3,98 & $5.091,02$ \\
\hline B3 - Manutenção & & & & & & - \\
\hline Combate de formiga + limpeza de & 1 homem para 4 hectares & 0,02 & diárias & 50,00 & - & - \\
\hline B4 - Exploração & & & & & & - \\
\hline Colheita manual & Maio (0-24 meses) e novembro (todo o rebanho) & 1,0 & diárias & 50,00 & - & - \\
\hline C-Insumos & & & & & & $5.241,46$ \\
\hline C1 - Corretivos e fertilizantes & & & & & & $1.950,20$ \\
\hline Calcário & ton/ha & 1,00 & $\mathrm{R} \$ /$ ton & 80,00 & - & - \\
\hline Formulação (05-10-15) & ton/ha na implantação & 0,70 & $\mathrm{R} \$ /$ ton & 700,00 & 3,98 & $1.950,20$ \\
\hline Formulação (10-00-15) & ton/ha em cobertura (sem incorporação) & 1,00 & $\mathrm{R} \$ /$ ton & 500,00 & - & - \\
\hline C2 - Agroquímicos & & & & & & 107,26 \\
\hline Formicidas & unidade por ha & 1,00 & $\mathrm{R} \$ / \mathrm{kg}$ & 5,70 & 3,98 & 22,69 \\
\hline $2,4-D$ & quantidade em I/ha & 2,50 & $\mathrm{R} \$ / \mathrm{I}$ & 8,50 & 3,98 & 84,58 \\
\hline C3 - Mudas & & & & & & $3.184,00$ \\
\hline Fornecimento de mudas & valor das mudas para 1 hectare & 1,00 & $\mathrm{R} \$$ / unid & 800,00 & 3,98 & $3.184,00$ \\
\hline Total $A+B+C$ & & & & & & $12.435,99$ \\
\hline
\end{tabular}


continua

\begin{tabular}{|c|c|c|c|c|c|c|c|c|c|c|}
\hline \multirow{2}{*}{ Descrição } & \multicolumn{2}{|c|}{ ANO 2 (2010) } & \multicolumn{2}{|c|}{ ANO 3 (2011) } & \multicolumn{2}{|c|}{ ANO 4 (2012) } & \multicolumn{2}{|c|}{ ANO 5 (2013) } & \multicolumn{2}{|c|}{ ANO 6 (2014) } \\
\hline & Quant. & $\mathrm{R} \$$ & Quant. & $\mathrm{R} \$$ & Quant. & $\mathrm{R} \$$ & Quant. & $\mathrm{R} \$$ & Quant. & $\mathrm{R} \$$ \\
\hline A - Operações mecanizadas - terceiros & & & & 608,94 & & 811,92 & & 608,94 & & 811,92 \\
\hline A1 - Implantação e manutenção & & - & & 608,94 & & 811,92 & & 608,94 & & 811,92 \\
\hline Aplicação herbicida (Dessecação) & - & - & - & - & - & - & - & - & - & - \\
\hline Carregamento de calcário e fertilizante & - & - & 11,94 & 71,64 & 15,92 & 71,64 & 11,94 & 71,64 & 15,92 & 71,64 \\
\hline Aplicação de calcário e fertilizante & - & - & 11,94 & 537,30 & 15,92 & 537,30 & 11,94 & 537,30 & 15,92 & 537,30 \\
\hline Subsolagem & - & - & - & - & - & - & - & - & - & - \\
\hline Gradagem pesada & - & - & - & - & - & - & - & - & - & - \\
\hline Gradagem intermediária & - & - & - & - & - & - & - & - & - & - \\
\hline Gradagem niveladora & - & - & - & - & - & - & - & - & - & - \\
\hline Construção de linhas de nível terraceamento & - & - & - & - & - & - & - & - & - & - \\
\hline Construção de carreadores & - & - & - & - & - & - & - & - & - & - \\
\hline A2 - Implantação (plantio) & & - & & - & & - & & - & & - \\
\hline Sulcação / adubação de plantio & - & - & - & - & - & - & - & - & - & - \\
\hline Distribuição de composto & - & - & - & - & - & - & - & - & - & - \\
\hline Cobertura de mudas & - & - & - & - & - & - & - & - & - & - \\
\hline Carregamento de mudas & - & - & - & - & - & - & - & - & - & - \\
\hline Transporte & - & - & - & - & - & - & - & - & - & - \\
\hline Reboque & - & - & - & - & - & - & - & - & - & - \\
\hline A3 - Tratos culturais & & - & & - & & - & & - & & - \\
\hline Aplicação de herbicidas & - & - & - & - & - & - & - & - & - & - \\
\hline Cultivo duplo & - & - & - & - & - & - & - & - & - & - \\
\hline
\end{tabular}


conclusão

\begin{tabular}{|c|c|c|c|c|c|c|c|c|c|c|}
\hline B B - Operações manuais & & - & & - & & 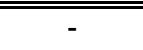 & &  & & 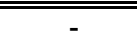 \\
\hline B1 - Preparo de solo (inicial) & - & - & - & - & - & - & - & - & - & - \\
\hline Carregamento e aplicação de calcário & - & - & - & - & - & - & - & - & - & - \\
\hline B2 - Plantio & & - & & - & & - & & - & & - \\
\hline Análise de solo & - & - & - & - & - & - & - & - & - & - \\
\hline Plantio manual (equipe) & - & - & - & - & - & - & - & - & - & - \\
\hline B3 - Manutenção & & - & & - & & - & & - & & - \\
\hline Combate de formiga & - & - & - & - & - & - & - & - & - & - \\
\hline B4 - Exploração & & - & & - & & - & & - & & - \\
\hline Colheita manual & - & - & - & - & - & - & - & - & - & - \\
\hline C - Insumos & 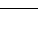 & - & & $2.012,69$ & & $2.012,69$ & & $2.012,69$ & & $2.012,69$ \\
\hline C1 - Corretivos e fertilizantes & - & - & & $1.990,00$ & & $1.990,00$ & & $1.990,00$ & & $1.990,00$ \\
\hline Calcário & - & - & - & - & - & - & - & - & - & - \\
\hline Formulação (05-10-15) & - & - & - & - & - & - & - & - & - & - \\
\hline Formulação (10-00-15) & - & - & 3,98 & $1.990,00$ & 3,98 & $1.990,00$ & 3,98 & $1.990,00$ & 3,98 & $1.990,00$ \\
\hline C2 - Agroquímicos & & - & & 22,69 & & 22,69 & & 22,69 & & 22,69 \\
\hline Formicidas & - & - & 3,98 & 22,69 & 3,98 & 22,69 & 3,98 & 22,69 & 3,98 & 22,69 \\
\hline $2,4-D$ & - & - & - & - & - & - & - & - & - & - \\
\hline C3-Mudas & & - & & - & & - & & - & & - \\
\hline Fornecimento de mudas & - & - & - & - & - & - & - & - & - & - \\
\hline Total $A+B+C$ & & - & & $2.621,63$ & & $2.824,61$ & & $2.621,63$ & & $2.824,61$ \\
\hline
\end{tabular}


continua

\begin{tabular}{|c|c|c|c|c|c|c|c|c|c|c|}
\hline \multirow{2}{*}{ Descrição } & \multicolumn{2}{|c|}{ ANO 7 (2015) } & \multicolumn{2}{|c|}{ ANO 8 (2016) } & \multicolumn{2}{|c|}{ ANO 9 (2017) } & \multicolumn{2}{|c|}{ ANO 10 (2018) } & \multicolumn{2}{|c|}{ ANO 11 (2019) } \\
\hline & Quant. & $\mathrm{R} \$$ & Quant. & $\mathrm{R} \$$ & Quant. & $\mathrm{R} \$$ & Quant. & $\mathrm{R} \$$ & Quant. & $\mathrm{R} \$$ \\
\hline A - Operações mecanizadas - terceiros & & 608,94 & & 608,94 & & $3.118,41$ & & 811,92 & & 608,94 \\
\hline A1 - Implantação e manutenção & & 608,94 & & 608,94 & & $1.956,25$ & & 811,92 & & 608,94 \\
\hline Aplicação herbicida (Dessecação) & - & - & - & - & - & - & - & - & - & - \\
\hline Carregamento de calcário e fertilizante & 11,94 & 71,64 & 11,94 & 71,64 & 19,90 & 119,40 & 15,92 & 71,64 & 11,94 & 71,64 \\
\hline Aplicação de calcário e fertilizante & 11,94 & 537,30 & 11,94 & 537,30 & 19,90 & 895,50 & 15,92 & 537,30 & 11,94 & 537,30 \\
\hline Subsolagem & - & - & - & - & - & - & - & - & - & - \\
\hline Gradagem pesada & - & - & - & - & 3,98 & 533,00 & - & - & - & - \\
\hline Gradagem intermediária & - & - & - & - & 3,98 & 408,35 & - & - & - & - \\
\hline Gradagem niveladora & - & - & - & - & - & - & - & - & - & - \\
\hline Construção de linhas de nível terraceamento & - & - & - & - & - & - & - & - & - & - \\
\hline Construção de carreadores & - & - & - & - & - & - & - & - & - & - \\
\hline A2 - Implantação (plantio) & & - & & - & & 764,16 & & - & & - \\
\hline Sulcação / adubação de plantio & - & - & - & - & 3,98 & 611,13 & - & - & - & - \\
\hline Distribuição de composto & - & - & - & - & - & - & - & - & - & - \\
\hline Cobertura de mudas & - & - & - & - & 3,98 & 152,83 & - & - & - & - \\
\hline Carregamento de mudas & - & - & - & - & - & - & - & - & - & - \\
\hline Transporte & - & - & - & - & - & - & - & - & - & - \\
\hline Reboque & - & - & - & - & - & - & - & - & - & - \\
\hline A3 - Tratos culturais & & - & & - & & 398,00 & & - & & - \\
\hline Aplicação de herbicidas & - & - & - & - & 3,98 & 199,00 & - & - & - & - \\
\hline Cultivo duplo & - & - & - & - & 3,98 & 199,00 & - & - & - & - \\
\hline
\end{tabular}


conclusão

\begin{tabular}{|c|c|c|c|c|c|c|c|c|c|c|}
\hline בB - Operações manuais & & 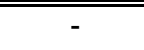 & & - & & 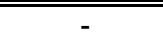 & & 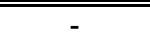 & & 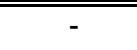 \\
\hline B1 - Preparo de solo (inicial) & - & - & - & - & - & - & - & - & - & - \\
\hline Carregamento e aplicação de calcário & - & - & - & - & - & - & - & - & - & - \\
\hline B2 - Plantio & & - & & - & - & $5.191,02$ & & - & & - \\
\hline Análise de solo & - & - & - & - & 1,00 & 100,00 & - & - & - & - \\
\hline Plantio manual (equipe) & - & - & - & - & 3,98 & $5.091,02$ & - & - & - & - \\
\hline B3 - Manutenção & & - & & & - & - & & - & & \\
\hline Combate de formiga + limpeza de & - & - & - & - & - & - & - & - & - & - \\
\hline B4 - Exploração & & - & & - & & - & & - & & - \\
\hline Colheita manual & - & - & - & - & - & - & - & - & - & - \\
\hline C-Insumos & & $2.012,69$ & & $2.012,69$ & & $5.559,86$ & & $2.012,69$ & & $2.012,69$ \\
\hline C1 - Corretivos e fertilizantes & & $1.990,00$ & & $1.990,00$ & & $2.268,60$ & & $1.990,00$ & & $1.990,00$ \\
\hline Calcário & - & - & - & - & 3,98 & 318,40 & - & - & - & - \\
\hline Formulação (05-10-15) & - & - & - & - & 3,98 & $1.950,20$ & - & - & - & - \\
\hline Formulação (10-00-15) & 3,98 & $1.990,00$ & 3,98 & $1.990,00$ & - & - & 3,98 & $1.990,00$ & 3,98 & $1.990,00$ \\
\hline C2 - Agroquímicos & & 22,69 & & 22,69 & & 107,26 & & 22,69 & & 22,69 \\
\hline Formicidas & 3,98 & 22,69 & 3,98 & 22,69 & 3,98 & 22,69 & 3,98 & 22,69 & 3,98 & 22,69 \\
\hline $2,4-D$ & - & - & - & - & 3,98 & 84,58 & - & - & - & - \\
\hline C3 - Mudas & & - & & - & & $3.184,00$ & & - & & - \\
\hline Fornecimento de mudas & - & - & - & - & 3,98 & $3.184,00$ & - & - & - & - \\
\hline Total $A+B+C$ & & $2.621,63$ & & $2.621,63$ & & $13.769,29$ & & $2.824,61$ & & $2.621,63$ \\
\hline
\end{tabular}


continua

\begin{tabular}{|c|c|c|c|c|c|c|c|c|c|c|}
\hline \multirow{2}{*}{ Descrição } & \multicolumn{2}{|c|}{ ANO $12(2020)$} & \multicolumn{2}{|c|}{ ANO $13(2021)$} & \multicolumn{2}{|c|}{ ANO 14 (2022) } & \multicolumn{2}{|c|}{ ANO 15 (2023) } & \multicolumn{2}{|c|}{ ANO 16 (2024) } \\
\hline & Quant. & $\mathrm{R} \$$ & Quant. & $\mathrm{R} \$$ & Quant. & $\mathrm{R} \$$ & Quant. & $\mathrm{R} \$$ & Quant. & $\mathrm{R} \$$ \\
\hline A - Operações mecanizadas - terceiros & & 811,92 & & 608,94 & & 608,94 & & 608,94 & & 811,92 \\
\hline A1 - Implantação e manutenção & & 811,92 & & 608,94 & & 608,94 & & 608,94 & & 811,92 \\
\hline Aplicação herbicida (Dessecação) & - & - & - & - & - & - & - & - & - & - \\
\hline Carregamento de calcário e fertilizante & 15,92 & 71,64 & 11,94 & 71,64 & 11,94 & 71,64 & 11,94 & 71,64 & 15,92 & 71,64 \\
\hline Aplicação de calcário e fertilizante & 15,92 & 537,30 & 11,94 & 537,30 & 11,94 & 537,30 & 11,94 & 537,30 & 15,92 & 537,30 \\
\hline Subsolagem & - & - & - & - & - & - & - & - & - & - \\
\hline Gradagem pesada & - & - & - & - & - & - & - & - & - & - \\
\hline Gradagem intermediária & - & - & - & - & - & - & - & - & - & - \\
\hline Gradagem niveladora & - & - & - & - & - & - & - & - & - & - \\
\hline Construção de linhas de nível terraceamento & - & - & - & - & - & - & - & - & - & - \\
\hline Construção de carreadores & - & - & - & - & - & - & - & - & - & - \\
\hline A2 - Implantação (plantio) & & - & & - & & - & & - & & - \\
\hline Sulcação / adubação de plantio & - & - & - & - & - & - & - & - & - & - \\
\hline Distribuição de composto & - & - & - & - & - & - & - & - & - & - \\
\hline Cobertura de mudas & - & - & - & - & - & - & - & - & - & - \\
\hline Carregamento de mudas & - & - & - & - & - & - & - & - & - & - \\
\hline Transporte & - & - & - & - & - & - & - & - & - & - \\
\hline Reboque & - & - & - & - & - & - & - & - & - & - \\
\hline A3 - Tratos culturais & & - & & - & & - & & - & & - \\
\hline Aplicação de herbicidas & - & - & - & - & - & - & - & - & - & - \\
\hline Cultivo duplo & - & - & - & - & - & - & - & - & - & - \\
\hline
\end{tabular}


conclusão

\begin{tabular}{|c|c|c|c|c|c|c|c|c|c|c|}
\hline 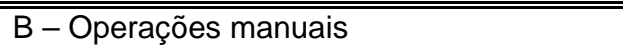 & & 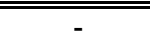 & &  & & 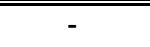 & & 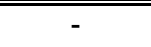 & & 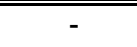 \\
\hline B1 - Preparo de solo (inicial) & - & - & - & - & - & - & - & - & - & - \\
\hline Carregamento e aplicação de calcário & - & - & - & - & - & - & - & - & - & - \\
\hline B2 - Plantio & & - & & - & & - & & - & & - \\
\hline Análise de solo & - & - & - & - & - & - & - & - & - & - \\
\hline Plantio manual (equipe) & - & - & - & - & - & - & - & - & - & - \\
\hline B3 - Manutenção & & - & & & & & & & & - \\
\hline Combate de formiga + limpeza de & - & - & - & - & - & - & - & - & - & - \\
\hline B4 - Exploração & & - & & - & & - & & - & & - \\
\hline Colheita manual & - & - & - & - & - & - & - & - & - & - \\
\hline $\mathrm{C}-$ Insumos & & $2.012,69$ & & $2.012,69$ & & $2.012,69$ & & $2.012,69$ & & $2.012,69$ \\
\hline C1 - Corretivos e fertilizantes & & $1.990,00$ & & $1.990,00$ & & $1.990,00$ & & $1.990,00$ & & $1.990,00$ \\
\hline Calcário & - & - & - & - & - & - & - & - & - & - \\
\hline Formulação (05-10-15) & - & - & - & - & - & - & - & - & - & - \\
\hline Formulação (10-00-15) & 3,98 & $1.990,00$ & 3,98 & $1.990,00$ & 3,98 & $1.990,00$ & 3,98 & $1.990,00$ & 3,98 & $1.990,00$ \\
\hline C2 - Agroquímicos & & 22,69 & & 22,69 & & 22,69 & & 22,69 & & 22,69 \\
\hline Formicidas & 3,98 & 22,69 & 3,98 & 22,69 & 3,98 & 22,69 & 3,98 & 22,69 & 3,98 & 22,69 \\
\hline $2,4-D$ & - & - & - & - & - & - & - & - & - & - \\
\hline C3 - Mudas & & - & & - & & - & & - & & - \\
\hline Fornecimento de mudas & - & - & - & - & - & - & - & - & - & - \\
\hline Total $A+B+C$ & & $2.824,61$ & & $2.621,63$ & & $2.621,63$ & & $2.621,63$ & & $2.824,61$ \\
\hline
\end{tabular}


continua

\begin{tabular}{|c|c|c|c|c|c|c|c|c|c|c|}
\hline \multirow{2}{*}{ Descrição } & \multicolumn{2}{|c|}{ ANO 17 (2025) } & \multicolumn{2}{|c|}{ ANO $18(2026)$} & \multicolumn{2}{|c|}{ ANO 19 (2027) } & \multicolumn{2}{|c|}{ ANO 20 (2028) } & \multicolumn{2}{|c|}{ ANO 21 (2029) } \\
\hline & Quant. & $\mathrm{R} \$$ & Quant. & $\mathrm{R} \$$ & Quant. & $\mathrm{R} \$$ & Quant. & $\mathrm{R} \$$ & Quant. & $\mathrm{R} \$$ \\
\hline A - Operações mecanizadas - terceiros & & $3.118,41$ & & 811,92 & & 608,94 & & 608,94 & & 608,94 \\
\hline A1 - Implantação e manutenção & & $1.956,25$ & & 811,92 & & 608,94 & & 608,94 & & 608,94 \\
\hline Aplicação herbicida (Dessecação) & - & - & - & - & - & - & - & - & - & - \\
\hline Carregamento de calcário e fertilizante & 19,90 & 119,40 & 15,92 & 71,64 & 11,94 & 71,64 & 11,94 & 71,64 & 11,94 & 71,64 \\
\hline Aplicação de calcário e fertilizante & 19,90 & 895,50 & 15,92 & 537,30 & 11,94 & 537,30 & 11,94 & 537,30 & 11,94 & 537,30 \\
\hline Subsolagem & - & - & - & - & - & - & - & - & - & - \\
\hline Gradagem pesada & 3,98 & 533,00 & - & - & - & - & - & - & - & - \\
\hline Gradagem intermediária & 3,98 & 408,35 & - & - & - & - & - & - & - & - \\
\hline Gradagem niveladora & - & - & - & - & - & - & - & - & - & - \\
\hline Construção de linhas de nível terraceamento & - & - & - & - & - & - & - & - & - & - \\
\hline Construção de carreadores & - & - & - & - & - & - & - & - & - & - \\
\hline A2 - Implantação (plantio) & & 764,16 & & - & & - & & - & & - \\
\hline Sulcação / adubação de plantio & 3,98 & 611,13 & - & - & - & - & - & - & - & - \\
\hline Distribuição de composto & - & - & - & - & - & - & - & - & - & - \\
\hline Cobertura de mudas & 3,98 & 152,83 & - & - & - & - & - & - & - & - \\
\hline Carregamento de mudas & - & - & - & - & - & - & - & - & - & - \\
\hline Transporte & - & - & - & - & - & - & - & - & - & - \\
\hline Reboque & - & - & - & - & - & - & - & - & - & - \\
\hline A3 - Tratos culturais & & 398,00 & & - & & - & & - & & - \\
\hline Aplicação de herbicidas & 3,98 & 199,00 & - & - & - & - & - & - & - & - \\
\hline Cultivo duplo & 3,98 & 199,00 & - & - & - & - & - & - & - & - \\
\hline
\end{tabular}


conclusão

\begin{tabular}{|c|c|c|c|c|c|c|c|c|c|c|}
\hline 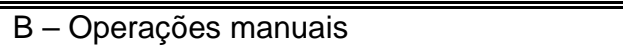 & & 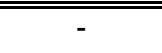 & & - & & - & & 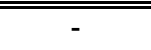 & & 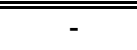 \\
\hline B1 - Preparo de solo (inicial) & - & - & - & - & - & - & - & - & - & - \\
\hline Carregamento e aplicação de calcário & - & - & - & - & - & - & - & - & - & - \\
\hline B2 - Plantio & - & $5.191,02$ & & - & & - & & - & & - \\
\hline Análise de solo & 1,00 & 100,00 & - & - & - & - & - & - & - & - \\
\hline Plantio manual (equipe) & 3,98 & $5.091,02$ & - & - & - & - & - & - & - & - \\
\hline B3 - Manutenção & - & - & - & - & - & - & - & - & - & \\
\hline Combate de formiga + limpeza de & - & - & - & - & - & - & - & - & - & - \\
\hline B4 - Exploração & & - & - & - & - & - & & - & - & - \\
\hline Colheita manual & - & - & - & - & - & - & - & - & - & - \\
\hline $\mathrm{C}-$ Insumos & & $5.559,86$ & & $2.012,69$ & & $2.012,69$ & & $2.012,69$ & & $2.012,69$ \\
\hline C1 - Corretivos e fertilizantes & & $2.268,60$ & & $1.990,00$ & & $1.990,00$ & & $1.990,00$ & & $1.990,00$ \\
\hline Calcário & 3,98 & 318,40 & - & - & - & - & - & - & - & - \\
\hline Formulação (05-10-15) & 3,98 & $1.950,20$ & - & - & - & - & - & - & - & - \\
\hline Formulação (10-00-15) & - & - & 3,98 & $1.990,00$ & 3,98 & $1.990,00$ & 3,98 & $1.990,00$ & 3,98 & $1.990,00$ \\
\hline C2 - Agroquímicos & & 107,26 & & 22,69 & & 22,69 & & 22,69 & & 22,69 \\
\hline Formicidas & 3,98 & 22,69 & 3,98 & 22,69 & 3,98 & 22,69 & 3,98 & 22,69 & 3,98 & 22,69 \\
\hline $2,4-D$ & 3,98 & 84,58 & - & - & - & - & - & - & - & - \\
\hline C3-Mudas & & $3.184,00$ & & - & & - & & - & & - \\
\hline Fornecimento de mudas & 3,98 & $3.184,00$ & - & - & - & - & - & - & - & - \\
\hline Total $A+B+C$ & & $13.769,29$ & & $2.824,61$ & & $2.621,63$ & & $2.621,63$ & & $2.621,63$ \\
\hline
\end{tabular}


continua

\begin{tabular}{|c|c|c|c|c|c|c|c|c|c|c|}
\hline \multirow{2}{*}{ Descrição } & \multicolumn{2}{|c|}{ ANO $22(2030)$} & \multicolumn{2}{|c|}{ ANO 23 (2031) } & \multicolumn{2}{|c|}{ ANO 24 (2032) } & \multicolumn{2}{|c|}{ ANO 25 (2033) } & \multicolumn{2}{|c|}{ ANO 26 (2034) } \\
\hline & Quant. & $\mathrm{R} \$$ & Quant. & $\mathrm{R} \$$ & Quant. & $\mathrm{R} \$$ & Quant. & $\mathrm{R} \$$ & Quant. & $\mathrm{R} \$$ \\
\hline A - Operações mecanizadas - terceiros & & 811,92 & & 608,94 & & 608,94 & & $3.118,41$ & & 608,94 \\
\hline A1 - Implantação e manutenção & & 811,92 & & 608,94 & & 608,94 & & $1.956,25$ & & 608,94 \\
\hline Aplicação herbicida (Dessecação) & - & - & - & - & - & - & - & - & - & - \\
\hline Carregamento de calcário e fertilizante & 15,92 & 71,64 & 11,94 & 71,64 & 11,94 & 71,64 & 19,90 & 119,40 & 11,94 & 71,64 \\
\hline Aplicação de calcário e fertilizante & 15,92 & 537,30 & 11,94 & 537,30 & 11,94 & 537,30 & 19,90 & 895,50 & 11,94 & 537,30 \\
\hline Subsolagem & - & - & - & - & - & - & - & - & - & - \\
\hline Gradagem pesada & - & - & - & - & - & - & 3,98 & 533,00 & - & - \\
\hline Gradagem intermediária & - & - & - & - & - & - & 3,98 & 408,35 & - & - \\
\hline Gradagem niveladora & - & - & - & - & - & - & - & - & - & - \\
\hline Construção de linhas de nível terraceamento & - & - & - & - & - & - & - & - & - & - \\
\hline Construção de carreadores & - & - & - & - & - & - & - & - & - & - \\
\hline A2 - Implantação (plantio) & & - & & - & & - & & 764,16 & & - \\
\hline Sulcação / adubação de plantio & - & - & - & - & - & - & 3,98 & 611,13 & - & - \\
\hline Distribuição de composto & - & - & - & - & - & - & - & - & - & - \\
\hline Cobertura de mudas & - & - & - & - & - & - & 3,98 & 152,83 & - & - \\
\hline Carregamento de mudas & - & - & - & - & - & - & - & - & - & - \\
\hline Transporte & - & - & - & - & - & - & - & - & - & - \\
\hline Reboque & - & - & - & - & - & - & - & - & - & - \\
\hline A3 - Tratos culturais & & - & & - & & - & & 398,00 & & - \\
\hline Aplicação de herbicidas & - & - & - & - & - & - & 3,98 & 199,00 & - & - \\
\hline Cultivo duplo & - & - & - & - & - & - & 3,98 & 199,00 & - & - \\
\hline
\end{tabular}


conclusão

\begin{tabular}{|c|c|c|c|c|c|c|c|c|c|c|}
\hline "B - Operações manuais & &  & & 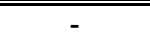 & & 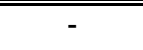 & & 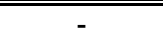 & & 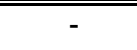 \\
\hline B1 - Preparo de solo (inicial) & - & - & - & - & - & - & - & - & - & - \\
\hline Carregamento e aplicação de calcário & - & - & - & - & - & - & - & - & - & - \\
\hline B2 - Plantio & & - & & - & & - & - & $5.191,02$ & & - \\
\hline Análise de solo & - & - & - & - & - & - & 1,00 & 100,00 & - & - \\
\hline Plantio manual (equipe) & - & - & - & - & - & - & 3,98 & $5.091,02$ & - & - \\
\hline B3 - Manutenção & & - & & & & & - & - & & \\
\hline Combate de formiga + limpeza de & - & - & - & - & - & - & - & - & - & - \\
\hline B4 - Exploração & & - & & - & & - & & - & & - \\
\hline Colheita manual & - & - & - & - & - & - & - & - & - & - \\
\hline C-Insumos & & $2.012,69$ & & $2.012,69$ & & $2.012,69$ & & $5.559,86$ & & $2.012,69$ \\
\hline C1 - Corretivos e fertilizantes & & $1.990,00$ & & $1.990,00$ & & $1.990,00$ & & $2.268,60$ & & $1.990,00$ \\
\hline Calcário & - & - & - & - & - & - & 3,98 & 318,40 & - & - \\
\hline Formulação (05-10-15) & - & - & - & - & - & - & 3,98 & $1.950,20$ & - & - \\
\hline Formulação (10-00-15) & 3,98 & $1.990,00$ & 3,98 & $1.990,00$ & 3,98 & $1.990,00$ & - & - & 3,98 & $1.990,00$ \\
\hline C2 - Agroquímicos & & 22,69 & & 22,69 & & 22,69 & & 107,26 & & 22,69 \\
\hline Formicidas & 3,98 & 22,69 & 3,98 & 22,69 & 3,98 & 22,69 & 3,98 & 22,69 & 3,98 & 22,69 \\
\hline $2,4-D$ & - & - & - & - & - & - & 3,98 & 84,58 & - & - \\
\hline C3-Mudas & & - & & - & & - & & $3.184,00$ & & - \\
\hline Fornecimento de mudas & - & - & - & - & - & - & 3,98 & $3.184,00$ & - & - \\
\hline Total $A+B+C$ & & $2.824,61$ & & $2.621,63$ & & $2.621,63$ & & $13.769,29$ & & $2.621,63$ \\
\hline
\end{tabular}


continua

\begin{tabular}{|c|c|c|c|c|c|c|c|c|}
\hline \multirow{2}{*}{ Descrição } & \multicolumn{2}{|c|}{ ANO 27 (2035) } & \multicolumn{2}{|c|}{ ANO 28 (2036) } & \multicolumn{2}{|c|}{ ANO 29 (2037) } & \multicolumn{2}{|c|}{ ANO 30 (2038) } \\
\hline & Quant. & $\mathrm{R} \$$ & Quant. & $\mathrm{R} \$$ & Quant. & $\mathrm{R} \$$ & Quant. & $\mathrm{R} \$$ \\
\hline A - Operações mecanizadas - terceiros & & 608,94 & & 811,92 & & 608,94 & & 811,92 \\
\hline A1 - Implantação e manutenção & & 608,94 & & 811,92 & & 608,94 & & 811,92 \\
\hline Aplicação herbicida (Dessecação) & - & - & - & - & - & - & - & - \\
\hline Carregamento de calcário e fertilizante & 11,94 & 71,64 & 15,92 & 71,64 & 11,94 & 71,64 & 15,92 & 71,64 \\
\hline Aplicação de calcário e fertilizante & 11,94 & 537,30 & 15,92 & 537,30 & 11,94 & 537,30 & 15,92 & 537,30 \\
\hline Subsolagem & - & - & - & - & - & - & - & - \\
\hline Gradagem pesada & - & - & - & - & - & - & - & - \\
\hline Gradagem intermediária & - & - & - & - & - & - & - & - \\
\hline Gradagem niveladora & - & - & - & - & - & - & - & - \\
\hline Construção de linhas de nível terraceamento & - & - & - & - & - & - & - & - \\
\hline Construção de carreadores & - & - & - & - & - & - & - & - \\
\hline A2 - Implantação (plantio) & & - & & - & & - & & - \\
\hline Sulcação / adubação de plantio & - & - & - & - & - & - & - & - \\
\hline Distribuição de composto & - & - & - & - & - & - & - & - \\
\hline Cobertura de mudas & - & - & - & - & - & - & - & - \\
\hline Carregamento de mudas & - & - & - & - & - & - & - & - \\
\hline Transporte & - & - & - & - & - & - & - & - \\
\hline Reboque & - & - & - & - & - & - & - & - \\
\hline A3 - Tratos culturais & & - & & - & & - & & - \\
\hline Aplicação de herbicidas & - & - & - & - & - & - & - & - \\
\hline Cultivo duplo & - & - & - & - & - & - & - & - \\
\hline
\end{tabular}


conclusão

\begin{tabular}{|c|c|c|c|c|c|c|c|c|}
\hline B - Operações manuais & & 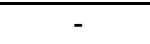 & & $\overline{-}$ & & 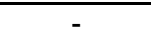 & &  \\
\hline B1 - Preparo de solo (inicial) & - & - & - & - & - & - & - & - \\
\hline Carregamento e aplicação de calcário & - & - & - & - & - & - & - & - \\
\hline B2 - Plantio & & - & & - & & - & & - \\
\hline Análise de solo & - & - & - & - & - & - & - & - \\
\hline Plantio manual (equipe) & - & - & - & - & - & - & - & - \\
\hline B3 - Manutenção & & & & - & & & & - \\
\hline Combate de formiga + limpeza de & - & - & - & - & - & - & - & - \\
\hline B4 - Exploração & & - & & - & & - & & - \\
\hline Colheita manual & - & - & - & - & - & - & - & - \\
\hline $\mathrm{C}-$ Insumos & & $2.012,69$ & & $2.012,69$ & & $2.012,69$ & & $2.012,69$ \\
\hline C1 - Corretivos e fertilizantes & & $1.990,00$ & & $1.990,00$ & & $1.990,00$ & & $1.990,00$ \\
\hline Calcário & - & - & - & - & - & - & - & - \\
\hline Formulação (05-10-15) & - & - & - & - & - & - & - & - \\
\hline Formulação (10-00-15) & 3,98 & $1.990,00$ & 3,98 & $1.990,00$ & 3,98 & $1.990,00$ & 3,98 & $1.990,00$ \\
\hline C2 - Agroquímicos & & 22,69 & & 22,69 & & 22,69 & & 22,69 \\
\hline Formicidas & 3,98 & 22,69 & 3,98 & 22,69 & 3,98 & 22,69 & 3,98 & 22,69 \\
\hline $2,4-D$ & - & - & - & - & - & - & - & - \\
\hline C3 - Mudas & & - & & - & & - & & - \\
\hline Fornecimento de mudas & - & - & - & - & - & - & - & - \\
\hline Total $A+B+C$ & & $2.621,63$ & & $2.824,61$ & & $2.621,63$ & & $2.824,61$ \\
\hline
\end{tabular}




\section{APÊNDICE G - Formação e manutenção das pastagens}

continua

\begin{tabular}{|c|c|c|c|c|c|c|}
\hline \multirow{2}{*}{ Descrição } & \multirow{2}{*}{ Especificações / Observações } & \multirow{2}{*}{ Coef. } & \multirow{2}{*}{ Unid. } & \multirow{2}{*}{$\begin{array}{c}\text { Unitário } \\
\mathrm{R} \$\end{array}$} & \multicolumn{2}{|c|}{ ANO 1 (2009) } \\
\hline & & & & & Quant. & $\mathrm{R} \$$ \\
\hline A - Operações mecanizadas - terceiros & & & & & & - \\
\hline A1 - Implantação e manutenção & & & & & - & - \\
\hline Aplicação herbicida (Dessecação) & Trator 71-90 cv + Implemento & 0,50 & hora/máq & 90,00 & - & - \\
\hline Carregamento de calcário e fertilizantes & Trator $71-90 \mathrm{cv}$ + caçamba carregadeira & 0,10 & hora/máq & 60,00 & - & - \\
\hline Aplicação de calcário e fertilizante & Trator $71-90 \mathrm{cv}+$ distribuidor de calcário & 0,30 & hora/máq & 60,00 & - & - \\
\hline Subsolagem & Trator $180 \mathrm{cv}+$ subsolador 3 hastes & 1,50 & hora/máq & 114,00 & - & - \\
\hline Gradagem pesada & Trator $180 \mathrm{cv}+$ grade $16 \times 32 "$ & 1,24 & hora/máq & 108,00 & - & - \\
\hline Gradagem intermediária & Trator $180 \mathrm{cv}+$ grade $32 \times 26 "$ & 0,90 & hora/máq & 114,00 & - & - \\
\hline A2 - Implantação (plantio) & & & & & & - \\
\hline Semeadura a lanço & Trator $71-90 \mathrm{cv}+$ semeadeira & 0,50 & hora/máq & 90,00 & - & - \\
\hline Gradagem niveladora & Trator $180 \mathrm{cv}+$ grade $32 \times 26 "$ & 0,70 & hora/máq & 114,00 & - & - \\
\hline A3 - Tratos culturais & & & & & & - \\
\hline Aplicação de herbicidas & Trator 71-90 cv + implemento & 0,50 & hora/máq & 90,00 & - & - \\
\hline Adubação em cobertura & Trator $150 \mathrm{cv}+$ implemento & 0,50 & hora/máq & 100,00 & - & - \\
\hline B - Operações manuais & & & & & & - \\
\hline B1 - Preparo de solo (inicial) & & & & & & - \\
\hline Carregamento e aplicação de calcário & Diária & 1,00 & Diárias & 100,00 & - & - \\
\hline B2 - Plantio & & & & & - & - \\
\hline Análise de solo & 1 analise anual para cada 4 hectares & 1,00 & $\mathrm{vb}$ & 100,00 & - & - \\
\hline B3 - Manutenção & & & & & & - \\
\hline Combate de formiga + aceiros & 1 homem para 4 hectares & 0,02 & Diárias & 50,00 & - & - \\
\hline
\end{tabular}


conclusão

\begin{tabular}{|c|c|c|c|c|c|c|}
\hline \multicolumn{5}{|l|}{ C C-Insumos } & & \\
\hline C1 - Corretivos e fertilizantes & & & & & & \\
\hline Calcário & ton/ha & 1,00 & $\mathrm{R} \$ /$ ton & 80,00 & - & - \\
\hline Formulação (05-10-15) & ton/ha na implantação & 0,70 & $\mathrm{R} \$ /$ ton & 700,00 & - & - \\
\hline Formulação (20-00-20) & ton/ha em cobertura $\left(1^{\mathrm{a}}, 2^{\mathrm{a}}, 3^{\mathrm{a}}, 4^{\mathrm{a}}\right.$ e $5^{\mathrm{a}}$ parcelas $)$ & 1,50 & $\mathrm{R} \$$ / ton & 700,00 & - & - \\
\hline C2 - Agroquímicos & & & & & & - \\
\hline Formicida & 1 unidade por ha & 1,00 & $\mathrm{R} \$ / \mathrm{kg}$ & 5,70 & - & - \\
\hline Tordon (Dessecação) & quantidade em $\mathrm{kg} / \mathrm{ha}$ & 2,00 & $\mathrm{R} \$ / I$ & 35,00 & - & - \\
\hline Glifosato & quantidade em $\mathrm{kg} / \mathrm{ha}$ & 5,00 & $\mathrm{R} \$ / \mathrm{I}$ & 6,00 & - & - \\
\hline Dominum & quantidade em $\mathrm{kg} / \mathrm{ha}$ & 1,50 & $\mathrm{R} \$ / \mathrm{I}$ & 63,00 & - & - \\
\hline Grazon & quantidade em $\mathrm{kg} / \mathrm{ha}$ & 3,00 & $\mathrm{R} \$ / \mathrm{I}$ & 14,00 & - & - \\
\hline Tordon (Controle) & quantidade em $\mathrm{kg} / \mathrm{ha}$ & 2,50 & $\mathrm{R} \$ / \mathrm{I}$ & 35,00 & - & - \\
\hline C3 - Sementes & & & & & & - \\
\hline Brachiaria brizantha cv Marandu & quantidade em $\mathrm{kg} / \mathrm{ha}$ & 10,00 & $\mathrm{R} \$$ / Unid & 5,20 & - & - \\
\hline Panicum maximum cv Mombaça & quantidade em $\mathrm{kg} / \mathrm{ha}$ & 10,00 & $\mathrm{R} \$$ / Unid & 5,40 & - & - \\
\hline Total $A+B+C$ & & & & & & - \\
\hline
\end{tabular}


continua

\begin{tabular}{|c|c|c|c|c|c|c|c|c|c|c|}
\hline \multirow{2}{*}{ Descrição } & \multicolumn{2}{|c|}{ ANO 2 (2010) } & \multicolumn{2}{|c|}{ ANO 3 (2011) } & \multicolumn{2}{|c|}{ ANO 4 (2012) } & \multicolumn{2}{|c|}{ ANO 5 (2013) } & \multicolumn{2}{|c|}{ ANO 6 (2014) } \\
\hline & Quant. & $\mathrm{R} \$$ & Quant. & $\mathrm{R} \$$ & Quant. & $\mathrm{R} \$$ & Quant. & $\mathrm{R} \$$ & Quant. & $\mathrm{R} \$$ \\
\hline A - Operações mecanizadas - terceiros & & $7.203,07$ & & $1.723,68$ & & $2.154,60$ & & $1.723,68$ & & $2.154,60$ \\
\hline A1 - Implantação e manutenção & & $4.493,06$ & & $1.723,68$ & & $1.436,50$ & & $1.723,68$ & & $1.436,50$ \\
\hline Aplicação herbicida (Dessecação) & 15,96 & 718,20 & - & - & - & - & - & - & - & - \\
\hline Carregamento de calcário e fertilizantes & - & - & - & - & - & - & - & - & - & - \\
\hline Aplicação de calcário e fertilizante & - & - & 95,76 & $1.723,68$ & 79,80 & $1.436,40$ & 95,76 & $1.723,68$ & 79,80 & $1.436,40$ \\
\hline Subsolagem & - & - & - & - & - & - & - & - & - & - \\
\hline Gradagem pesada & 15,96 & $2.137,36$ & - & - & - & - & - & - & - & - \\
\hline Gradagem intermediária & 15,96 & $1.637,50$ & - & - & - & - & - & - & - & - \\
\hline A2 - Implantação (plantio) & & $1.991,81$ & & - & & - & & - & & - \\
\hline Semeadura a lanço & 15,96 & 718,20 & - & - & - & - & - & - & - & - \\
\hline Gradagem niveladora & 15,96 & $1.273,61$ & - & - & - & - & - & - & - & - \\
\hline A3 - Tratos culturais & - & 718,20 & - & - & - & 718,20 & - & - & - & 718,20 \\
\hline Aplicação de herbicidas & 15,96 & 718,20 & - & - & 15,96 & 718,20 & - & - & 15,96 & 718,20 \\
\hline Adubação em cobertura & - & - & - & - & - & - & - & - & - & - \\
\hline B - Operações manuais & & - & & 100,00 & - & - & & 100,00 & - & - \\
\hline B1 - Preparo de solo (inicial) & - & - & - & - & - & - & - & - & - & - \\
\hline Carregamento e aplicação de calcário & - & - & - & - & - & - & - & - & - & - \\
\hline B2 - Plantio & - & - & - & - & - & - & - & - & - & - \\
\hline Análise de solo & - & - & 1,00 & 100,00 & - & - & 1,00 & 100,00 & - & - \\
\hline B3 - Manutenção & & - & & - & & - & & - & & - \\
\hline Combate de formiga + aceiros & - & - & - & - & - & - & - & - & - & - \\
\hline
\end{tabular}


conclusão

\begin{tabular}{|c|c|c|c|c|c|c|c|c|c|c|}
\hline $\bar{C}-$ Insumos & & $4.575,11$ & & $18.125,77$ & & $18.245,47$ & & $18.125,77$ & & $18.245,47$ \\
\hline C1 - Corretivos e fertilizantes & & - & & $18.034,80$ & & $16.758,00$ & & $18.034,80$ & & $16.758,00$ \\
\hline Calcário & - & - & 15,96 & $1.276,80$ & - & - & 15,96 & $1.276,80$ & - & - \\
\hline Formulação (05-10-15) & - & - & - & - & - & - & - & - & - & - \\
\hline Formulação (20-00-20) & - & - & 15,96 & $16.758,00$ & 15,96 & $16.758,00$ & 15,96 & $16.758,00$ & 15,96 & $16.758,00$ \\
\hline C2 - Agroquímicos & & $4.142,57$ & & 90,97 & & $1.487,47$ & & 90,97 & & $1.487,47$ \\
\hline Formicida & 15,96 & 90,97 & 15,96 & 90,97 & 15,96 & 90,97 & 15,96 & 90,97 & 15,96 & 90,97 \\
\hline Tordon (Dessecação) & 15,96 & $1.117,20$ & - & - & - & - & - & - & - & - \\
\hline Glifosato & 15,96 & 478,80 & - & - & - & - & - & - & - & - \\
\hline Dominum & 3,80 & 359,10 & - & - & - & - & - & - & - & - \\
\hline Grazon & 8,00 & 336,00 & - & - & - & - & - & - & - & - \\
\hline Tordon (Controle) & 20,12 & $1.760,50$ & - & - & 15,96 & $1.396,50$ & - & - & 15,96 & $1.396,50$ \\
\hline C3 - Sementes & & 432,54 & & - & & - & & - & & - \\
\hline Brachiaria brizantha cv Marandu & 7,95 & 413,40 & - & - & - & - & - & - & - & - \\
\hline Panicum maximum cv Mombaça & 8,01 & 432,54 & - & - & - & - & - & - & - & - \\
\hline Total $A+B+C$ & & $11.778,18$ & & $19.949,45$ & & $20.400,07$ & & $19.949,45$ & & $20.400,07$ \\
\hline
\end{tabular}


continua

\begin{tabular}{|c|c|c|c|c|c|c|c|c|c|c|}
\hline \multirow{2}{*}{ Descrição } & \multicolumn{2}{|c|}{ ANO 7 (2015) } & \multicolumn{2}{|c|}{ ANO 8 (2016) } & \multicolumn{2}{|c|}{ ANO 9 (2017) } & \multicolumn{2}{|c|}{ ANO $10(2018)$} & \multicolumn{2}{|c|}{ ANO 11 (2019) } \\
\hline & Quant. & $\mathrm{R} \$$ & Quant. & $\mathrm{R} \$$ & Quant. & $\mathrm{R} \$$ & Quant. & $\mathrm{R} \$$ & Quant. & $\mathrm{R} \$$ \\
\hline A - Operações mecanizadas - terceiros & & $1.723,68$ & & $2.154,60$ & & $1.723,68$ & & $2.154,60$ & & $1.723,68$ \\
\hline A1 - Implantação e manutenção & & $1.723,68$ & & $1.436,50$ & & $1.723,68$ & & $1.436,50$ & & $1.723,68$ \\
\hline Aplicação herbicida (Dessecação) & - & - & - & - & - & - & - & - & - & - \\
\hline Carregamento de calcário e fertilizantes & - & - & - & - & - & - & - & - & - & - \\
\hline Aplicação de calcário e fertilizante & 95,76 & $1.723,68$ & 79,80 & $1.436,40$ & 95,76 & $1.723,68$ & 79,80 & $1.436,40$ & 95,76 & $1.723,68$ \\
\hline Subsolagem & - & - & - & - & - & - & - & - & - & - \\
\hline Gradagem pesada & - & - & - & - & - & - & - & - & - & - \\
\hline Gradagem intermediária & - & - & - & - & - & - & - & - & - & - \\
\hline A2 - Implantação (plantio) & & - & & - & & - & & - & & - \\
\hline Semeadura a lanço & - & - & - & - & - & - & - & - & - & - \\
\hline Gradagem niveladora & - & - & - & - & - & - & - & - & - & - \\
\hline A3 - Tratos culturais & - & - & - & 718,20 & - & - & - & 718,20 & - & - \\
\hline Aplicação de herbicidas & - & - & 15,96 & 718,20 & - & - & 15,96 & 718,20 & - & - \\
\hline Adubação em cobertura & - & - & - & - & - & - & - & - & - & - \\
\hline B - Operações manuais & & 100,00 & - & - & & 100,00 & - & - & & 100,00 \\
\hline B1 - Preparo de solo (inicial) & - & - & - & - & - & - & - & - & - & - \\
\hline Carregamento e aplicação de calcário & - & - & - & - & - & - & - & - & - & - \\
\hline B2 - Plantio & - & - & - & - & - & - & - & - & - & - \\
\hline Análise de solo & 1,00 & 100,00 & - & - & 1,00 & 100,00 & - & - & 1,00 & 100,00 \\
\hline B3 - Manutenção & & - & & - & & - & & - & & - \\
\hline Combate de formiga + aceiros & - & - & - & - & - & - & - & - & - & - \\
\hline
\end{tabular}


conclusão

\begin{tabular}{|c|c|c|c|c|c|c|c|c|c|c|}
\hline $\mathrm{C}-$ Insumos & & $18.125,77$ & & $18.245,47$ & & $18.125,77$ & & $18.245,47$ & & $18.125,77$ \\
\hline C1 - Corretivos e fertilizantes & & $18.034,80$ & & $16.758,00$ & & $18.034,80$ & & $16.758,00$ & & $18.034,80$ \\
\hline Calcário & 15,96 & $1.276,80$ & - & - & 15,96 & $1.276,80$ & - & - & 15,96 & $1.276,80$ \\
\hline Formulação (05-10-15) & - & - & - & - & - & - & - & - & - & - \\
\hline Formulação (20-00-20) & 15,96 & $16.758,00$ & 15,96 & $16.758,00$ & 15,96 & $16.758,00$ & 15,96 & $16.758,00$ & 15,96 & $16.758,00$ \\
\hline C2 - Agroquímicos & & 90,97 & & $1.487,47$ & & 90,97 & & $1.487,47$ & & 90,97 \\
\hline Formicida & 15,96 & 90,97 & 15,96 & 90,97 & 15,96 & 90,97 & 15,96 & 90,97 & 15,96 & 90,97 \\
\hline Tordon (Dessecação) & - & - & - & - & - & - & - & - & - & - \\
\hline Glifosato & - & - & - & - & - & - & - & - & - & - \\
\hline Dominum & - & - & - & - & - & - & - & - & - & - \\
\hline Grazon & - & - & - & - & - & - & - & - & - & - \\
\hline Tordon (Controle) & - & - & 15,96 & $1.396,50$ & - & - & 15,96 & $1.396,50$ & - & - \\
\hline C3 - Sementes & & - & & - & & - & & - & & - \\
\hline Brachiaria brizantha cv Marandu & - & - & - & - & - & - & - & - & - & - \\
\hline Panicum maximum cv Mombaça & - & - & - & - & - & - & - & - & - & - \\
\hline Total $A+B+C$ & & $19.949,45$ & & $20.400,07$ & & $19.949,45$ & & $20.400,07$ & & $19.949,45$ \\
\hline
\end{tabular}


continua

\begin{tabular}{|c|c|c|c|c|c|c|c|c|c|c|}
\hline \multirow{2}{*}{ Descrição } & \multicolumn{2}{|c|}{ ANO $12(2020)$} & \multicolumn{2}{|c|}{ ANO $13(2021)$} & \multicolumn{2}{|c|}{ ANO 14 (2022) } & \multicolumn{2}{|c|}{ ANO 15 (2023) } & \multicolumn{2}{|c|}{ ANO 16 (2024) } \\
\hline & Quant. & $\mathrm{R} \$$ & Quant. & $\mathrm{R} \$$ & Quant. & $\mathrm{R} \$$ & Quant. & $\mathrm{R} \$$ & Quant. & $\mathrm{R} \$$ \\
\hline A - Operações mecanizadas - terceiros & & $2.154,60$ & & $1.723,68$ & & $2.154,60$ & & $1.723,68$ & & $2.154,60$ \\
\hline A1 - Implantação e manutenção & & $1.436,50$ & & $1.723,68$ & & $1.436,50$ & & $1.723,68$ & & $1.436,50$ \\
\hline Aplicação herbicida (Dessecação) & - & - & - & - & - & - & - & - & - & - \\
\hline Carregamento de calcário e fertilizantes & - & - & - & - & - & - & - & - & - & - \\
\hline Aplicação de calcário e fertilizante & 79,80 & $1.436,40$ & 95,76 & $1.723,68$ & 79,80 & $1.436,40$ & 95,76 & $1.723,68$ & 79,80 & $1.436,40$ \\
\hline Subsolagem & - & - & - & - & - & - & - & - & - & - \\
\hline Gradagem pesada & - & - & - & - & - & - & - & - & - & - \\
\hline Gradagem intermediária & - & - & - & - & - & - & - & - & - & - \\
\hline A2 - Implantação (plantio) & & - & & - & & - & & - & & - \\
\hline Semeadura a lanço & - & - & - & - & - & - & - & - & - & - \\
\hline Gradagem niveladora & - & - & - & - & - & - & - & - & - & - \\
\hline A3 - Tratos culturais & - & 718,20 & - & - & - & 718,20 & - & - & - & 718,20 \\
\hline Aplicação de herbicidas & 15,96 & 718,20 & - & - & 15,96 & 718,20 & - & - & 15,96 & 718,20 \\
\hline Adubação em cobertura & - & - & - & - & - & - & - & - & - & - \\
\hline B - Operações manuais & - & - & & 100,00 & - & - & & 100,00 & - & - \\
\hline B1 - Preparo de solo (inicial) & - & - & - & - & - & - & - & - & - & - \\
\hline Carregamento e aplicação de calcário & - & - & - & - & - & - & - & - & - & - \\
\hline B2 - Plantio & - & - & - & - & - & - & - & - & - & - \\
\hline Análise de solo & - & - & 1,00 & 100,00 & - & - & 1,00 & 100,00 & - & - \\
\hline B3 - Manutenção & & - & & - & & - & & - & & - \\
\hline Combate de formiga + aceiros & - & - & - & - & - & - & - & - & - & - \\
\hline
\end{tabular}


conclusão

\begin{tabular}{|c|c|c|c|c|c|c|c|c|c|c|}
\hline C C-Insumos & & $18.245,47$ & & $1818.125,77$ & & $18.245,47$ & & $18.125,77$ & & $18.245,47$ \\
\hline C1 - Corretivos e fertilizantes & & $16.758,00$ & & $18.034,80$ & & $16.758,00$ & & $18.034,80$ & & $16.758,00$ \\
\hline Calcário & - & - & 15,96 & $1.276,80$ & - & - & 15,96 & $1.276,80$ & - & - \\
\hline Formulação (05-10-15) & - & - & - & - & - & - & - & - & - & - \\
\hline Formulação (20-00-20) & 15,96 & $16.758,00$ & 15,96 & $16.758,00$ & 15,96 & $16.758,00$ & 15,96 & $16.758,00$ & 15,96 & $16.758,00$ \\
\hline C2 - Agroquímicos & & $1.487,47$ & & 90,97 & & $1.487,47$ & & 90,97 & & $1.487,47$ \\
\hline Formicida & 15,96 & 90,97 & 15,96 & 90,97 & 15,96 & 90,97 & 15,96 & 90,97 & 15,96 & 90,97 \\
\hline Tordon (Dessecação) & - & - & - & - & - & - & - & - & - & - \\
\hline Glifosato & - & - & - & - & - & - & - & - & - & - \\
\hline Dominum & - & - & - & - & - & - & - & - & - & - \\
\hline Grazon & - & - & - & - & - & - & - & - & - & - \\
\hline Tordon (Controle) & 15,96 & $1.396,50$ & - & - & 15,96 & $1.396,50$ & - & - & 15,96 & $1.396,50$ \\
\hline C3 - Sementes & & - & & - & & - & & - & & - \\
\hline Brachiaria brizantha cv Marandu & - & - & - & - & - & - & - & - & - & - \\
\hline Panicum maximum cv Mombaça & - & - & - & - & - & - & - & - & - & - \\
\hline Total $A+B+C$ & & $20.400,07$ & & $19.949,45$ & & $20.400,07$ & & $19.949,45$ & & $20.400,07$ \\
\hline
\end{tabular}


continua

\begin{tabular}{|c|c|c|c|c|c|c|c|c|c|c|}
\hline \multirow{2}{*}{ Descrição } & \multicolumn{2}{|c|}{ ANO 17 (2025) } & \multicolumn{2}{|c|}{ ANO 18 (2026) } & \multicolumn{2}{|c|}{ ANO 19 (2027) } & \multicolumn{2}{|c|}{ ANO 20 (2028) } & \multicolumn{2}{|c|}{ ANO 21 (2029) } \\
\hline & Quant. & $\mathrm{R} \$$ & Quant. & $\mathrm{R} \$$ & Quant. & $\mathrm{R} \$$ & Quant. & $\mathrm{R} \$$ & Quant. & $\mathrm{R} \$$ \\
\hline A - Operações mecanizadas - terceiros & & $1.723,68$ & & $2.154,60$ & & $1.723,68$ & & $2.154,60$ & & $1.723,68$ \\
\hline A1 - Implantação e manutenção & & $1.723,68$ & & $1.436,50$ & & $1.723,68$ & & $1.436,50$ & & $1.723,68$ \\
\hline Aplicação herbicida (Dessecação) & - & - & - & - & - & - & - & - & - & - \\
\hline Carregamento de calcário e fertilizantes & - & - & - & - & - & - & - & - & - & - \\
\hline Aplicação de calcário e fertilizante & 95,76 & $1.723,68$ & 79,80 & $1.436,40$ & 95,76 & $1.723,68$ & 79,80 & $1.436,40$ & 95,76 & $1.723,68$ \\
\hline Subsolagem & - & - & - & - & - & - & - & - & - & - \\
\hline Gradagem pesada & - & - & - & - & - & - & - & - & - & - \\
\hline Gradagem intermediária & - & - & - & - & - & - & - & - & - & - \\
\hline A2 - Implantação (plantio) & & - & & - & & - & & - & & - \\
\hline Semeadura a lanço & - & - & - & - & - & - & - & - & - & - \\
\hline Gradagem niveladora & - & - & - & - & - & - & - & - & - & - \\
\hline A3 - Tratos culturais & - & - & - & 718,20 & - & - & - & 718,20 & - & - \\
\hline Aplicação de herbicidas & - & - & 15,96 & 718,20 & - & - & 15,96 & 718,20 & - & - \\
\hline Adubação em cobertura & - & - & - & - & - & - & - & - & - & - \\
\hline B - Operações manuais & & 100,00 & - & - & & 100,00 & - & - & & 100,00 \\
\hline B1 - Preparo de solo (inicial) & - & - & - & - & - & - & - & - & - & - \\
\hline Carregamento e aplicação de calcário & - & - & - & - & - & - & - & - & - & - \\
\hline B2 - Plantio & - & - & - & - & - & - & - & - & - & - \\
\hline Análise de solo & 1,00 & 100,00 & - & - & 1,00 & 100,00 & - & - & 1,00 & 100,00 \\
\hline B3 - Manutenção & & - & & - & & - & & - & & - \\
\hline Combate de formiga + aceiros & - & - & - & - & - & - & - & - & - & - \\
\hline
\end{tabular}


conclusão

\begin{tabular}{|c|c|c|c|c|c|c|c|c|c|c|}
\hline $\mathrm{C}-$ Insumos & & $18.125,77$ & & $18.245,47$ & & $18.125,77$ & & $18.245,47$ & & $18.125,77$ \\
\hline C1 - Corretivos e fertilizantes & & $18.034,80$ & & $16.758,00$ & & $18.034,80$ & & $16.758,00$ & & $18.034,80$ \\
\hline Calcário & 15,96 & $1.276,80$ & - & - & 15,96 & $1.276,80$ & - & - & 15,96 & $1.276,80$ \\
\hline Formulação (05-10-15) & - & - & - & - & - & - & - & - & - & - \\
\hline Formulação (20-00-20) & 15,96 & $16.758,00$ & 15,96 & $16.758,00$ & 15,96 & $16.758,00$ & 15,96 & $16.758,00$ & 15,96 & $16.758,00$ \\
\hline C2 - Agroquímicos & & 90,97 & & $1.487,47$ & & 90,97 & & $1.487,47$ & & 90,97 \\
\hline Formicida & 15,96 & 90,97 & 15,96 & 90,97 & 15,96 & 90,97 & 15,96 & 90,97 & 15,96 & 90,97 \\
\hline Tordon (Dessecação) & - & - & - & - & - & - & - & - & - & - \\
\hline Glifosato & - & - & - & - & - & - & - & - & - & - \\
\hline Dominum & - & - & - & - & - & - & - & - & - & - \\
\hline Grazon & - & - & - & - & - & - & - & - & - & - \\
\hline Tordon (Controle) & - & - & 15,96 & $1.396,50$ & - & - & 15,96 & $1.396,50$ & - & - \\
\hline C3 - Sementes & & - & & - & & - & & - & & - \\
\hline Brachiaria brizantha cv Marandu & - & - & - & - & - & - & - & - & - & - \\
\hline Panicum maximum cv Mombaça & - & - & - & - & - & - & - & - & - & - \\
\hline Total $A+B+C$ & & $19.949,45$ & & $20.400,07$ & & $19.949,45$ & & $20.400,07$ & & $19.949,45$ \\
\hline
\end{tabular}


continua

\begin{tabular}{|c|c|c|c|c|c|c|c|c|c|c|}
\hline \multirow{2}{*}{ Descrição } & \multicolumn{2}{|c|}{ ANO 22 (2030) } & \multicolumn{2}{|c|}{ ANO 23 (2031) } & \multicolumn{2}{|c|}{ ANO 24 (2032) } & \multicolumn{2}{|c|}{ ANO 25 (2033) } & \multicolumn{2}{|c|}{ ANO 26 (2034) } \\
\hline & Quant. & $\mathrm{R} \$$ & Quant. & $\mathrm{R} \$$ & Quant. & $\mathrm{R} \$$ & Quant. & $\mathrm{R} \$$ & Quant. & $\mathrm{R} \$$ \\
\hline A - Operações mecanizadas - terceiros & & $2.154,60$ & & $1.723,68$ & & $2.154,60$ & & $1.723,68$ & & $2.154,60$ \\
\hline A1 - Implantação e manutenção & & $1.436,50$ & & $1.723,68$ & & $1.436,50$ & & $1.723,68$ & & $1.436,50$ \\
\hline Aplicação herbicida (Dessecação) & - & - & - & - & - & - & - & - & - & - \\
\hline Carregamento de calcário e fertilizantes & - & - & - & - & - & - & - & - & - & - \\
\hline Aplicação de calcário e fertilizante & 79,80 & $1.436,40$ & 95,76 & $1.723,68$ & 79,80 & $1.436,40$ & 95,76 & $1.723,68$ & 79,80 & $1.436,40$ \\
\hline Subsolagem & - & - & - & - & - & - & - & - & - & - \\
\hline Gradagem pesada & - & - & - & - & - & - & - & - & - & - \\
\hline Gradagem intermediária & - & - & - & - & - & - & - & - & - & - \\
\hline A2 - Implantação (plantio) & & - & & - & & - & & - & & - \\
\hline Semeadura a lanço & - & - & - & - & - & - & - & - & - & - \\
\hline Gradagem niveladora & - & - & - & - & - & - & - & - & - & - \\
\hline A3 - Tratos culturais & - & 718,20 & - & - & - & 718,20 & - & - & - & 718,20 \\
\hline Aplicação de herbicidas & 15,96 & 718,20 & - & - & 15,96 & 718,20 & - & - & 15,96 & 718,20 \\
\hline Adubação em cobertura & - & - & - & - & - & - & - & - & - & - \\
\hline B - Operações manuais & - & - & & 100,00 & - & - & & 100,00 & - & - \\
\hline B1 - Preparo de solo (inicial) & - & - & - & - & - & - & - & - & - & - \\
\hline Carregamento e aplicação de calcário & - & - & - & - & - & - & - & - & - & - \\
\hline B2 - Plantio & - & - & - & - & - & - & - & - & - & - \\
\hline Análise de solo & - & - & 1,00 & 100,00 & - & - & 1,00 & 100,00 & - & - \\
\hline B3 - Manutenção & & - & & - & & - & & - & & - \\
\hline Combate de formiga + aceiros & - & - & - & - & - & - & - & - & - & - \\
\hline
\end{tabular}


conclusão

\begin{tabular}{|c|c|c|c|c|c|c|c|c|c|c|}
\hline C-Insumos & & $18.245,47$ & & $18.125,77$ & & $18.245,47$ & & $18.125,77$ & & $18.245,47$ \\
\hline C1 - Corretivos e fertilizantes & & $16.758,00$ & & $18.034,80$ & & $16.758,00$ & & $18.034,80$ & & $16.758,00$ \\
\hline Calcário & - & - & 15,96 & $1.276,80$ & - & - & 15,96 & $1.276,80$ & - & - \\
\hline Formulação (05-10-15) & - & - & - & - & - & - & - & - & - & - \\
\hline Formulação (20-00-20) & 15,96 & $16.758,00$ & 15,96 & $16.758,00$ & 15,96 & $16.758,00$ & 15,96 & $16.758,00$ & 15,96 & $16.758,00$ \\
\hline C2 - Agroquímicos & & $1.487,47$ & & 90,97 & & $1.487,47$ & & 90,97 & & $1.487,47$ \\
\hline Formicida & 15,96 & 90,97 & 15,96 & 90,97 & 15,96 & 90,97 & 15,96 & 90,97 & 15,96 & 90,97 \\
\hline Tordon (Dessecação) & - & - & - & - & - & - & - & - & - & - \\
\hline Glifosato & - & - & - & - & - & - & - & - & - & - \\
\hline Dominum & - & - & - & - & - & - & - & - & - & - \\
\hline Grazon & - & - & - & - & - & - & - & - & - & - \\
\hline Tordon (Controle) & 15,96 & $1.396,50$ & - & - & 15,96 & $1.396,50$ & - & - & 15,96 & $1.396,50$ \\
\hline C3 - Sementes & & - & & - & & - & & - & & - \\
\hline Brachiaria brizantha cv Marandu & - & - & - & - & - & - & - & - & - & - \\
\hline Panicum maximum cv Mombaça & - & - & - & - & - & - & - & - & - & - \\
\hline Total $A+B+C$ & & $20.400,07$ & & $19.949,45$ & & $20.400,07$ & & $19.949,45$ & & $20.400,07$ \\
\hline
\end{tabular}


continua

\begin{tabular}{|c|c|c|c|c|c|c|c|c|}
\hline \multirow{2}{*}{ Descrição } & \multicolumn{2}{|c|}{ ANO 27 (2035) } & \multicolumn{2}{|c|}{ ANO 28 (2036) } & \multicolumn{2}{|c|}{ ANO 29 (2037) } & \multicolumn{2}{|c|}{ ANO 30 (2038) } \\
\hline & Quant. & $\mathrm{R} \$$ & Quant. & $\mathrm{R} \$$ & Quant. & $\mathrm{R} \$$ & Quant. & $\mathrm{R} \$$ \\
\hline A - Operações mecanizadas - terceiros & & $1.723,68$ & & $2.154,60$ & & $1.723,68$ & & $2.154,60$ \\
\hline A1 - Implantação e manutenção & & $1.723,68$ & & $1.436,50$ & & $1.723,68$ & & $1.436,50$ \\
\hline Aplicação herbicida (Dessecação) & - & - & - & - & - & - & - & - \\
\hline Carregamento de calcário e fertilizantes & - & - & - & - & - & - & - & - \\
\hline Aplicação de calcário e fertilizante & 95,76 & $1.723,68$ & 79,80 & $1.436,40$ & 95,76 & $1.723,68$ & 79,80 & $1.436,40$ \\
\hline Subsolagem & - & - & - & - & - & - & - & - \\
\hline Gradagem pesada & - & - & - & - & - & - & - & - \\
\hline Gradagem intermediária & - & - & - & - & - & - & - & - \\
\hline A2 - Implantação (plantio) & & - & & - & & - & & - \\
\hline Semeadura a lanço & - & - & - & - & - & - & - & - \\
\hline Gradagem niveladora & - & - & - & - & - & - & - & - \\
\hline A3 - Tratos culturais & - & - & - & 718,20 & - & - & - & 718,20 \\
\hline Aplicação de herbicidas & - & - & 15,96 & 718,20 & - & - & 15,96 & 718,20 \\
\hline Adubação em cobertura & - & - & - & - & - & - & - & - \\
\hline B - Operações manuais & & 100,00 & - & - & & 100,00 & - & - \\
\hline B1 - Preparo de solo (inicial) & - & - & - & - & - & - & - & - \\
\hline Carregamento e aplicação de calcário & - & - & - & - & - & - & - & - \\
\hline B2 - Plantio & - & - & - & - & - & - & - & - \\
\hline Análise de solo & 1,00 & 100,00 & - & - & 1,00 & 100,00 & - & - \\
\hline B3 - Manutenção & & - & & - & & - & & - \\
\hline Combate de formiga + aceiros & - & - & - & - & - & - & - & - \\
\hline
\end{tabular}


conclusão

\begin{tabular}{|c|c|c|c|c|c|c|c|c|}
\hline C-Insumos & & $18.125,77$ & & $18.245,47$ & & $18.125,77$ & & $1818.245,47$ \\
\hline C1 - Corretivos e fertilizantes & & $18.034,80$ & & $16.758,00$ & & $18.034,80$ & & $16.758,00$ \\
\hline Calcário & 15,96 & $1.276,80$ & - & - & 15,96 & $1.276,80$ & - & - \\
\hline Formulação (05-10-15) & - & - & - & - & - & - & - & - \\
\hline Formulação (20-00-20) & 15,96 & $16.758,00$ & 15,96 & $16.758,00$ & 15,96 & $16.758,00$ & 15,96 & $16.758,00$ \\
\hline C2 - Agroquímicos & & 90,97 & & $1.487,47$ & & 90,97 & & $1.487,47$ \\
\hline Formicida & 15,96 & 90,97 & 15,96 & 90,97 & 15,96 & 90,97 & 15,96 & 90,97 \\
\hline Tordon (Dessecação) & - & - & - & - & - & - & - & - \\
\hline Glifosato & - & - & - & - & - & - & - & - \\
\hline Dominum & - & - & - & - & - & - & - & - \\
\hline Grazon & - & - & - & - & - & - & - & - \\
\hline Tordon (Controle) & - & - & 15,96 & $1.396,50$ & - & - & 15,96 & $1.396,50$ \\
\hline C3 - Sementes & & - & & - & & - & & - \\
\hline Brachiaria brizantha cv Marandu & - & - & - & - & - & - & - & - \\
\hline Panicum maximum cv Mombaça & - & - & - & - & - & - & - & - \\
\hline Total $A+B+C$ & & $19.949,45$ & & $20.400,07$ & & $19.949,45$ & & $20.400,07$ \\
\hline
\end{tabular}


APÊNDICE H - Manejo do rebanho

continua

\begin{tabular}{|c|c|c|c|c|c|c|c|c|}
\hline \multirow{2}{*}{ Descrição } & \multirow{2}{*}{ Especificações / Observações } & \multirow{2}{*}{ Coef. } & \multirow{2}{*}{ Unid. } & \multirow{2}{*}{$\begin{array}{c}\text { Unitário } \\
\mathrm{R} \$\end{array}$} & \multicolumn{2}{|c|}{ ANO 1 (2009) } & \multicolumn{2}{|c|}{ ANO $2(2010)$} \\
\hline & & & & & Quant. & $\mathrm{R} \$$ & Quant. & $\mathrm{R} \$$ \\
\hline A - Protocolo profilático sanitário & & & & & & & & 207,50 \\
\hline A1 - Oficial & & & & & & & & 105,00 \\
\hline Febre aftosa & Maio (0-24 meses) e novembro (todo o rebanho) & 1,00 & dose & 1,05 & - & - & 100 & 105,00 \\
\hline Brucelose & Maio e novembro (Fêmeas de 03 a 08 meses de idade) & 1,00 & dose & 0,42 & - & - & - & - \\
\hline A2 - Específico & & & & & & & & 102,50 \\
\hline Raiva & Maio (todo o rebanho) & 1,00 & dose & 0,36 & - & - & - & - \\
\hline Clostridiose & Maio e novembro (todo o rebanho) & 1,00 & dose & 0,52 & - & - & 100 & 52,00 \\
\hline Everminação & Maio e novembro (todo o rebanho - 05 ml por UA) & 1,00 & dose & 0,40 & - & - & 00 & 40,00 \\
\hline Everminação dos nascidos & Nascimento do animal (01 ml por 50 kg de peso vivo) & 1,00 & dose & 0,27 & - & - & - & - \\
\hline Tratamento contra onfalite & Nascimento do animal & 1,00 & $\mathrm{vb}$ & 10,50 & - & - & 1,00 & 10,50 \\
\hline B - Alimentação e suplementação & & & & & & & & 833,33 \\
\hline B1 - Suplementação mineral & & & & & & & & 833,33 \\
\hline Suplementação pronta para uso & Consumo médio por ano por unidade animal & 25,00 & $\mathrm{Kg} / \mathrm{UA} /$ ano & 1,00 & - & - & 33 & 833,33 \\
\hline \multicolumn{9}{|l|}{ B2 - Alimentação } \\
\hline Uréia + cana de açúcar in natura & 01 kg de uréia / 100 kg de cana de açúcar (peso fresco) & 1,00 & $\mathrm{~kg}$ & 1,00 & - & - & - & - \\
\hline Concentrado - Milho (seco) & & 1,00 & ton & 300,00 & - & - & - & - \\
\hline Sulfato de amônio & 01 parte de sulfato de amônio para 09 partes de uréia & 1,00 & $\mathrm{~kg}$ & 0,60 & - & - & - & - \\
\hline Dieta confinamento & & 1,00 & vb/animal & 394,12 & - & - & - & - \\
\hline C - Reprodução & & & & & & & & $4.080,00$ \\
\hline C1 - Medicamentos & & & & & & & & $1.800,00$ \\
\hline Protocolo (IATF) & & 1,00 & $\mathrm{vb}$ & 18,00 & - & - & 100 & $1.800,00$ \\
\hline C2 - Sêmem & & & & & & & & $1.950,00$ \\
\hline
\end{tabular}


conclusão

\begin{tabular}{|c|c|c|c|c|c|c|c|c|}
\hline Sêmem & & 1,30 & dose & 15,00 & 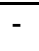 & 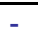 & 100 & $1.950,00$ \\
\hline C3 - Mão de obra específica & & & & & & & & 330,00 \\
\hline Exame brucelose & Médico veterinário & 1,00 & animal & 3,00 & - & - & 100,00 & 300,00 \\
\hline Inseminação & Médico veterinário & 1,00 & animal & 10,00 & - & - & 3,00 & 30,00 \\
\hline D - Custos Administrativos & & & & & & & & 782,19 \\
\hline Mão de obra administrativa & & 1,00 & $\mathrm{R} \$ / \mathrm{mês}$ & - & - & - & - & - \\
\hline Mão de obra para serviços gerais & 1 salário (piso da categoria) $+44,85 \%$ encargos & 1,00 & $\mathrm{R} \$ / \mathrm{mês}$ & 782,19 & - & - & 1 & 782,19 \\
\hline Custos $A+B+C+D$ & & & & & & & & $5.120,83$ \\
\hline
\end{tabular}


continua

\begin{tabular}{|c|c|c|c|c|c|c|c|c|c|c|c|c|}
\hline \multirow{2}{*}{ Descrição } & \multicolumn{2}{|c|}{ ANO 3 (2011) } & \multicolumn{2}{|c|}{ ANO 4 (2012) } & \multicolumn{2}{|c|}{ ANO 5 (2013) } & \multicolumn{2}{|c|}{ ANO 6 (2014) } & \multicolumn{2}{|c|}{ ANO 7 (2015) } & \multicolumn{2}{|c|}{ ANO 8 (2016) } \\
\hline & Quant. & $\mathrm{R} \$$ & Quant. & $\mathrm{R} \$$ & Quant. & $\mathrm{R} \$$ & Quant. & $\mathrm{R} \$$ & Quant. & $\mathrm{R} \$$ & Quant. & $\mathrm{R} \$$ \\
\hline A - Protocolo profilático sanitário & & 518,50 & & 649,60 & & 676,71 & & 658,78 & & 646,11 & & 646,74 \\
\hline A1 - Oficial & & 229,85 & & 277,07 & & 290,90 & & 283,25 & & 278,16 & & 278,41 \\
\hline Febre aftosa & 201 & 211,05 & 244 & 256,10 & 255 & 267,60 & 250 & 262,26 & 245 & 257,09 & 245 & 257,33 \\
\hline Brucelose & 45 & 18,90 & 50 & 20,98 & 55 & 23,29 & 50 & 20,99 & 50 & 21,08 & 50 & 21,08 \\
\hline A2 - Específico & & 288,55 & & 372,52 & & 385,81 & & 375,53 & & 367,95 & & 368,34 \\
\hline Raiva & 90 & 32,40 & 139 & 49,93 & 146 & 52,56 & 141 & 50,61 & 137 & 49,25 & 137 & 49,32 \\
\hline Clostridiose & 241 & 125,11 & 310 & 161,15 & 318 & 165,50 & 312 & 62,46 & 306 & 158,88 & 306 & 159,06 \\
\hline Everminação & 241 & 96,24 & 310 & 123,96 & 318 & 127,31 & 312 & 124,97 & 306 & 122,21 & 306 & 122,35 \\
\hline Everminação dos nascidos & 90 & 24,30 & 100 & 26,97 & 111 & 29,95 & 100 & 26,99 & 100 & 27,10 & 100 & 27,10 \\
\hline Tratamento contra onfalite & 1 & 10,50 & 1 & 10,50 & 1 & 10,50 & 1 & 10,50 & 1 & 10,50 & 1 & 10,50 \\
\hline B - Alimentação e suplementação & & $21.903,86$ & & $25.999,99$ & & $27.717,91$ & & $30.027,88$ & & $27.782,24$ & & $27.779,12$ \\
\hline B1 - Suplementação mineral & & $2.626,67$ & & $3.248,45$ & & $3.299,70$ & & $3.320,26$ & & $3.307,65$ & & $3.289,84$ \\
\hline Suplementação pronta para uso & 105 & $2.626,67$ & 130 & $3.248,45$ & 132 & $3.299,70$ & 133 & $3.320,26$ & 132 & $3.307,65$ & 132 & $3.289,84$ \\
\hline B2 - Alimentação & & $19.277,19$ & & $22.751,54$ & & $24.418,22$ & & $26.707,62$ & & $24.474,59$ & & $24.489,28$ \\
\hline Uréia + cana de açúcar in natura & 866 & 865,82 & 2.420 & $2.419,68$ & 2.284 & $2.283,75$ & 2.426 & $2.426,33$ & 2.309 & $2.308,96$ & 2.309 & $2.315,53$ \\
\hline Concentrado - Milho (seco) & 3 & $1.012,38$ & 9 & $2.829,27$ & 9 & $2.670,34$ & 9 & $2.837,05$ & 9 & $2.699,81$ & 9 & $2.707,50$ \\
\hline Sulfato de amônio & 96 & 57,72 & 269 & 161,31 & 254 & 152,25 & 270 & 161,76 & 257 & 153,93 & 257 & 154,37 \\
\hline Dieta confinamento & 44 & $17.341,28$ & 44 & $17.341,28$ & 49 & $19.311,88$ & 54 & $21.282,48$ & 49 & $19.311,88$ & 49 & $19.311,88$ \\
\hline C - Reprodução & & $5.062,50$ & & $4.646,25$ & & $4.462,50$ & & $4.480,58$ & & $4.480,95$ & & $4.481,25$ \\
\hline C1 - Medicamentos & & $1.998,00$ & & $1.798,20$ & & $1.170,00$ & & $1.718,68$ & & $1.718,85$ & & $1.719,00$ \\
\hline Protocolo (IATF) & 111 & $1.988,00$ & 100 & $1.798,20$ & 95 & $1.170,00$ & 95 & $1.718,68$ & 95 & $1.718,85$ & 95 & $1.719,00$ \\
\hline C2 - Sêmem & & $2.164,50$ & & $1.948,05$ & & 1852,50 & & $1.861,90$ & & $1.862,09$ & & $1.862,25$ \\
\hline Sêmem & 111 & $2.164,50$ & 100 & $1.948,05$ & 95 & 1852,50 & 95 & $1.861,90$ & 95 & $1.862,09$ & 95 & $1.862,25$ \\
\hline C3 - Mão de obra específica & & 900,00 & & 900,00 & & 900,00 & & 900,00 & & 900,00 & & 900,00 \\
\hline Exame brucelose & - & - & - & - & - & - & - & - & - & - & - & - \\
\hline
\end{tabular}


conclusão

\begin{tabular}{|c|c|c|c|c|c|c|c|c|c|c|c|c|}
\hline Inseminação & 2 & 900,00 & 2 & 900,00 & 2 & 900,00 & 2 & 900,00 & 2 & 900,00 & 2 & 900,00 \\
\hline D - Custos Administrativos & & $1.564,38$ & & $1.564,38$ & & $1.564,38$ & & $1.564,38$ & & $1.564,38$ & & $1.564,38$ \\
\hline Mão de obra administrativa & & - & & - & & - & & - & & - & & - \\
\hline Mão de obra para serviços gerais & 2 & $1.564,38$ & 2 & $1.564,38$ & 2 & 1564,38 & 2 & $1.564,38$ & 2 & $1.564,38$ & 2 & $1.564,38$ \\
\hline Custos $A+B+C+D$ & & $29.049,24$ & & $32.860,21$ & & $34.421,50$ & & $36.731,62$ & & $34.473,68$ & & $34.471,49$ \\
\hline
\end{tabular}


continua

\begin{tabular}{|c|c|c|c|c|c|c|c|c|c|c|c|c|}
\hline \multirow{2}{*}{ Descrição } & \multicolumn{2}{|c|}{ ANO 9 (2017) } & \multicolumn{2}{|c|}{ ANO 10 (2018) } & \multicolumn{2}{|c|}{ ANO 11 (2019) } & \multicolumn{2}{|c|}{ ANO $12(2020)$} & \multicolumn{2}{|c|}{ ANO 13 (2021) } & \multicolumn{2}{|c|}{ ANO 14 (2022) } \\
\hline & Quant. & $\mathrm{R} \$$ & Quant. & $\mathrm{R} \$$ & Quant. & $\mathrm{R} \$$ & Quant. & $\mathrm{R} \$$ & Quant. & $\mathrm{R} \$$ & Quant. & $\mathrm{R} \$$ \\
\hline A - Protocolo profilático sanitário & & 646,79 & & 646,79 & & 646,79 & & 646,79 & & 646,79 & & 646,79 \\
\hline A1 - Oficial & & 278,43 & & 278,43 & & 278,43 & & 278,43 & & 278,43 & & 278,43 \\
\hline Febre aftosa & 245 & 257,35 & 245 & 257,35 & 245 & 257,35 & 245 & 257,35 & 245 & 257,35 & 245 & 257,35 \\
\hline Brucelose & 50 & 21,08 & 50 & 20,08 & 50 & 20,08 & 50 & 20,08 & 50 & 20,08 & 50 & 20,08 \\
\hline A2 - Específico & & 368,36 & & 368,36 & & 368,36 & & 368,36 & & 368,36 & & 368,36 \\
\hline Raiva & 137 & 49,33 & 137 & 49,33 & 137 & 49,33 & 137 & 49,33 & 137 & 49,33 & 137 & 49,33 \\
\hline Clostridiose & 306 & 159,07 & 306 & 159,07 & 306 & 159,07 & 306 & 159,07 & 306 & 159,07 & 306 & 159,07 \\
\hline Everminação & 306 & 122,36 & 306 & 122,36 & 306 & 122,36 & 306 & 122,36 & 306 & 122,36 & 306 & 122,36 \\
\hline Everminação dos nascidos & 100 & 27,11 & 100 & 27,11 & 100 & 27,11 & 100 & 27,11 & 100 & 27,11 & 100 & 27,11 \\
\hline Tratamento contra onfalite & 1 & 10,50 & 1 & 10,50 & 1 & 10,50 & 1 & 10,50 & 1 & 10,50 & 1 & 10,50 \\
\hline B - Alimentação e suplementação & & $27.781,43$ & & $27.781,43$ & & $27.781,43$ & & $27.781,43$ & & $27.781,43$ & & $27.781,43$ \\
\hline B1 - Suplementação mineral & & $3.290,88$ & & $3.290,88$ & & $3.290,88$ & & $3.290,88$ & & $3.290,88$ & & $3.290,88$ \\
\hline Suplementação pronta para uso & 132 & $3.290,88$ & 132 & $3.290,88$ & 132 & $3.290,88$ & 132 & $3.290,88$ & 132 & $3.290,88$ & 132 & $3.290,88$ \\
\hline B2 - Alimentação & & $24.490,55$ & & $24.490,55$ & & $24.490,55$ & & $24.490,55$ & & $24.490,55$ & & $24.490,55$ \\
\hline Uréia + cana de açúcar in natura & 2.316 & $2.316,10$ & 2.316 & $2.316,10$ & 2.316 & $2.316,10$ & 2.316 & $2.316,10$ & 2.316 & $2.316,10$ & 2.316 & $2.316,10$ \\
\hline Concentrado - Milho (seco) & 9 & $2.708,16$ & 9 & $2.708,16$ & 9 & $2.708,16$ & 9 & $2.708,16$ & 9 & $2.708,16$ & 9 & $2.708,16$ \\
\hline Sulfato de amônio & 257 & 154,41 & 257 & 154,41 & 257 & 154,41 & 257 & 154,41 & 257 & 154,41 & 257 & 154,41 \\
\hline Dieta confinamento & 49 & $19.311,88$ & 49 & $19.311,88$ & 49 & $19.311,88$ & 49 & $19.311,88$ & 49 & $19.311,88$ & 49 & $19.311,88$ \\
\hline C - Reprodução & & $4.481,50$ & & $4.481,50$ & & $4.481,50$ & & $4.481,50$ & & $4.481,50$ & & $4.481,50$ \\
\hline C1 - Medicamentos & & $1.719,12$ & & $1.719,12$ & & $1.719,12$ & & $1.719,12$ & & $1.719,12$ & & $1.719,12$ \\
\hline Protocolo (IATF) & 96 & $1.719,12$ & 96 & $1.719,12$ & 96 & $1.719,12$ & 96 & $1.719,12$ & 96 & $1.719,12$ & 96 & $1.719,12$ \\
\hline C2 - Sêmem & & $1.862,38$ & & $1.862,38$ & & $1.862,38$ & & $1.862,38$ & & $1.862,38$ & & $1.862,38$ \\
\hline Sêmem & 96 & $1.862,38$ & 96 & $1.862,38$ & 96 & $1.862,38$ & 96 & $1.862,38$ & 96 & $1.862,38$ & 96 & $1.862,38$ \\
\hline C3 - Mão de obra específica & & 900,00 & & 900,00 & & 900,00 & & 900,00 & & 900,00 & & 900,00 \\
\hline Exame brucelose & - & - & - & - & - & - & - & - & - & - & - & - \\
\hline
\end{tabular}


conclusão

\begin{tabular}{|c|c|c|c|c|c|c|c|c|c|c|c|c|}
\hline Inseminação & $\overline{2} 2$ & 900,00 & 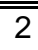 & 900,00 & 2 & 900,00 & 2 & 900,00 & $\overline{2} 2$ & 900,00 & 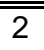 & 900,00 \\
\hline D - Custos Administrativos & & $1.564,38$ & & $1.564,38$ & & $1.564,38$ & & $1.564,38$ & & $1.564,38$ & & $1.564,38$ \\
\hline Mão de obra administrativa & & - & & - & & - & & - & & - & & - \\
\hline Mão de obra para serviços gerais & 2 & $1.564,38$ & 2 & $1.564,38$ & 2 & $1.564,38$ & 2 & $1.564,38$ & 2 & $1.564,38$ & 2 & $1.564,38$ \\
\hline Custos $A+B+C+D$ & & $34.474,11$ & & $34.474,11$ & & $34.474,11$ & & $34.474,11$ & & $34.474,11$ & & $34.474,11$ \\
\hline
\end{tabular}


continua

\begin{tabular}{|c|c|c|c|c|c|c|c|c|c|c|c|c|}
\hline \multirow{2}{*}{ Descrição } & \multicolumn{2}{|c|}{ ANO 15 (2023) } & \multicolumn{2}{|c|}{ ANO 16 (2024) } & \multicolumn{2}{|c|}{ ANO 17 (2025) } & \multicolumn{2}{|c|}{ ANO 18 (2026) } & \multicolumn{2}{|c|}{ ANO 19 (2027) } & \multicolumn{2}{|c|}{ ANO 20 (2028) } \\
\hline & Quant. & $\mathrm{R} \$$ & Quant. & $\mathrm{R} \$$ & Quant. & $\mathrm{R} \$$ & Quant. & $\mathrm{R} \$$ & Quant. & $\mathrm{R} \$$ & Quant. & $\mathrm{R} \$$ \\
\hline A - Protocolo profilático sanitário & & 646,79 & & 646,79 & & 646,79 & & 646,79 & & 646,79 & & 646,79 \\
\hline A1 - Oficial & & 278,43 & & 278,43 & & 278,43 & & 278,43 & & 278,43 & & 278,43 \\
\hline Febre aftosa & 245 & 257,35 & 245 & 257,35 & 245 & 257,35 & 245 & 257,35 & 245 & 257,35 & 245 & 257,35 \\
\hline Brucelose & 50 & 21,08 & 50 & 20,08 & 50 & 20,08 & 50 & 20,08 & 50 & 20,08 & 50 & 20,08 \\
\hline A2 - Específico & & 368,36 & & 368,36 & & 368,36 & & 368,36 & & 368,36 & & 368,36 \\
\hline Raiva & 137 & 49,33 & 137 & 49,33 & 137 & 49,33 & 137 & 49,33 & 137 & 49,33 & 137 & 49,33 \\
\hline Clostridiose & 306 & 159,07 & 306 & 159,07 & 306 & 159,07 & 306 & 159,07 & 306 & 159,07 & 306 & 159,07 \\
\hline Everminação & 306 & 122,36 & 306 & 122,36 & 306 & 122,36 & 306 & 122,36 & 306 & 122,36 & 306 & 122,36 \\
\hline Everminação dos nascidos & 100 & 27,11 & 100 & 27,11 & 100 & 27,11 & 100 & 27,11 & 100 & 27,11 & 100 & 27,11 \\
\hline Tratamento contra onfalite & 1 & 10,50 & 1 & 10,50 & 1 & 10,50 & 1 & 10,50 & 1 & 10,50 & 1 & 10,50 \\
\hline B - Alimentação e suplementação & & $27.781,43$ & & $27.781,43$ & & $27.781,43$ & & $27.781,43$ & & $27.781,43$ & & $27.781,43$ \\
\hline B1 - Suplementação mineral & & $3.290,88$ & & $3.290,88$ & & $3.290,88$ & & $3.290,88$ & & $3.290,88$ & & $3.290,88$ \\
\hline Suplementação pronta para uso & 132 & $3.290,88$ & 132 & $3.290,88$ & 132 & $3.290,88$ & 132 & $3.290,88$ & 132 & $3.290,88$ & 132 & $3.290,88$ \\
\hline B2 - Alimentação & & $24.490,55$ & & $24.490,55$ & & $24.490,55$ & & $24.490,55$ & & $24.490,55$ & & $24.490,55$ \\
\hline Uréia + cana de açúcar in natura & 2.316 & $2.316,10$ & 2.316 & $2.316,10$ & 2.316 & $2.316,10$ & 2.316 & $2.316,10$ & 2.316 & $2.316,10$ & 2.316 & $2.316,10$ \\
\hline Concentrado - Milho (seco) & 9 & $2.708,16$ & 9 & $2.708,16$ & 9 & $2.708,16$ & 9 & $2.708,16$ & 9 & $2.708,16$ & 9 & $2.708,16$ \\
\hline Sulfato de amônio & 257 & 154,41 & 257 & 154,41 & 257 & 154,41 & 257 & 154,41 & 257 & 154,41 & 257 & 154,41 \\
\hline Dieta confinamento & 49 & $19.311,88$ & 49 & $19.311,88$ & 49 & $19.311,88$ & 49 & $19.311,88$ & 49 & $19.311,88$ & 49 & $19.311,88$ \\
\hline C - Reprodução & & $4.481,50$ & & $4.481,50$ & & $4.481,50$ & & $4.481,50$ & & $4.481,50$ & & $4.481,50$ \\
\hline C1 - Medicamentos & & $1.719,12$ & & $1.719,12$ & & $1.719,12$ & & $1.719,12$ & & $1.719,12$ & & $1.719,12$ \\
\hline Protocolo (IATF) & 96 & $1.719,12$ & 96 & $1.719,12$ & 96 & $1.719,12$ & 96 & $1.719,12$ & 96 & $1.719,12$ & 96 & $1.719,12$ \\
\hline C2 - Sêmem & & $1.862,38$ & & $1.862,38$ & & $1.862,38$ & & $1.862,38$ & & $1.862,38$ & & $1.862,38$ \\
\hline Sêmem & 96 & $1.862,38$ & 96 & $1.862,38$ & 96 & $1.862,38$ & 96 & $1.862,38$ & 96 & $1.862,38$ & 96 & $1.862,38$ \\
\hline C3 - Mão de obra específica & & 900,00 & & 900,00 & & 900,00 & & 900,00 & & 900,00 & & 900,00 \\
\hline Exame brucelose & - & - & - & - & - & - & - & - & - & - & - & - \\
\hline
\end{tabular}


conclusão

\begin{tabular}{|c|c|c|c|c|c|c|c|c|c|c|c|c|}
\hline Inseminação & 2 & 900,00 & 2 & 900,00 & 2 & 900,00 & 2 & 900,00 & 2 & 900,00 & 2 & 900,00 \\
\hline D - Custos Administrativos & & $1.564,38$ & & $1.564,38$ & & $1.564,38$ & & $1.564,38$ & & $1.564,38$ & & $1.564,38$ \\
\hline Mão de obra administrativa & & - & & - & & - & & - & & - & & - \\
\hline Mão de obra para serviços gerais & 2 & $1.564,38$ & 2 & $1.564,38$ & 2 & $1.564,38$ & 2 & $1.564,38$ & 2 & $1.564,38$ & 2 & $1.564,38$ \\
\hline Custos $A+B+C+D$ & & $34.474,11$ & & $34.474,11$ & & $34.474,11$ & & $34.474,11$ & & $34.474,11$ & & $34.474,11$ \\
\hline
\end{tabular}


continua

\begin{tabular}{|c|c|c|c|c|c|c|c|c|c|c|c|c|}
\hline \multirow{2}{*}{ Descrição } & \multicolumn{2}{|c|}{ ANO 21 (2029) } & \multicolumn{2}{|c|}{ ANO 22 (2030) } & \multicolumn{2}{|c|}{ ANO 23 (2031) } & \multicolumn{2}{|c|}{ ANO 24 (2032) } & \multicolumn{2}{|c|}{ ANO 25 (2033) } & \multicolumn{2}{|c|}{ ANO 26 (2034) } \\
\hline & Quant. & $\mathrm{R} \$$ & Quant. & $\mathrm{R} \$$ & Quant. & $\mathrm{R} \$$ & Quant. & $\mathrm{R} \$$ & Quant. & $\mathrm{R} \$$ & Quant. & $\mathrm{R} \$$ \\
\hline A - Protocolo profilático sanitário & & 646,79 & & 646,79 & & 646,79 & & 646,79 & & 646,79 & & 646,79 \\
\hline A1 - Oficial & & 278,43 & & 278,43 & & 278,43 & & 278,43 & & 278,43 & & 278,43 \\
\hline Febre aftosa & 245 & 257,35 & 245 & 257,35 & 245 & 257,35 & 245 & 257,35 & 245 & 257,35 & 245 & 257,35 \\
\hline Brucelose & 50 & 21,08 & 50 & 20,08 & 50 & 20,08 & 50 & 20,08 & 50 & 20,08 & 50 & 20,08 \\
\hline A2 - Específico & & 368,36 & & 368,36 & & 368,36 & & 368,36 & & 368,36 & & 368,36 \\
\hline Raiva & 137 & 49,33 & 137 & 49,33 & 137 & 49,33 & 137 & 49,33 & 137 & 49,33 & 137 & 49,33 \\
\hline Clostridiose & 306 & 159,07 & 306 & 159,07 & 306 & 159,07 & 306 & 159,07 & 306 & 159,07 & 306 & 159,07 \\
\hline Everminação & 306 & 122,36 & 306 & 122,36 & 306 & 122,36 & 306 & 122,36 & 306 & 122,36 & 306 & 122,36 \\
\hline Everminação dos nascidos & 100 & 27,11 & 100 & 27,11 & 100 & 27,11 & 100 & 27,11 & 100 & 27,11 & 100 & 27,11 \\
\hline Tratamento contra onfalite & 1 & 10,50 & 1 & 10,50 & 1 & 10,50 & 1 & 10,50 & 1 & 10,50 & 1 & 10,50 \\
\hline B - Alimentação e suplementação & & $27.781,43$ & & $27.781,43$ & & $27.781,43$ & & $27.781,43$ & & $27.781,43$ & & $27.781,43$ \\
\hline B1 - Suplementação mineral & & $3.290,88$ & & $3.290,88$ & & $3.290,88$ & & $3.290,88$ & & $3.290,88$ & & $3.290,88$ \\
\hline Suplementação pronta para uso & 132 & $3.290,88$ & 132 & $3.290,88$ & 132 & $3.290,88$ & 132 & $3.290,88$ & 132 & $3.290,88$ & 132 & $3.290,88$ \\
\hline B2 - Alimentação & & $24.490,55$ & & $24.490,55$ & & $24.490,55$ & & $24.490,55$ & & $24.490,55$ & & $24.490,55$ \\
\hline Uréia + cana de açúcar in natura & 2.316 & $2.316,10$ & 2.316 & $2.316,10$ & 2.316 & $2.316,10$ & 2.316 & $2.316,10$ & 2.316 & $2.316,10$ & 2.316 & $2.316,10$ \\
\hline Concentrado - Milho (seco) & 9 & $2.708,16$ & 9 & $2.708,16$ & 9 & $2.708,16$ & 9 & $2.708,16$ & 9 & $2.708,16$ & 9 & $2.708,16$ \\
\hline Sulfato de amônio & 257 & 154,41 & 257 & 154,41 & 257 & 154,41 & 257 & 154,41 & 257 & 154,41 & 257 & 154,41 \\
\hline Dieta confinamento & 49 & $19.311,88$ & 49 & $19.311,88$ & 49 & $19.311,88$ & 49 & $19.311,88$ & 49 & $19.311,88$ & 49 & $19.311,88$ \\
\hline C - Reprodução & & $4.481,50$ & & $4.481,50$ & & $4.481,50$ & & $4.481,50$ & & $4.481,50$ & & $4.481,50$ \\
\hline C1 - Medicamentos & & $1.719,12$ & & $1.719,12$ & & $1.719,12$ & & $1.719,12$ & & $1.719,12$ & & $1.719,12$ \\
\hline Protocolo (IATF) & 96 & $1.719,12$ & 96 & $1.719,12$ & 96 & $1.719,12$ & 96 & $1.719,12$ & 96 & $1.719,12$ & 96 & $1.719,12$ \\
\hline C2 - Sêmem & & $1.862,38$ & & $1.862,38$ & & $1.862,38$ & & $1.862,38$ & & $1.862,38$ & & $1.862,38$ \\
\hline Sêmem & 96 & $1.862,38$ & 96 & $1.862,38$ & 96 & $1.862,38$ & 96 & $1.862,38$ & 96 & $1.862,38$ & 96 & $1.862,38$ \\
\hline C3 - Mão de obra específica & & 900,00 & & 900,00 & & 900,00 & & 900,00 & & 900,00 & & 900,00 \\
\hline Exame brucelose & - & - & - & - & - & - & - & - & - & - & - & - \\
\hline
\end{tabular}


conclusão

\begin{tabular}{|c|c|c|c|c|c|c|c|c|c|c|c|c|}
\hline Inseminação & 2 & 900,00 & 2 & 900,00 & 2 & 900,00 & 2 & 900,00 & 2 & 900,00 & 2 & 900,00 \\
\hline D - Custos Administrativos & & $1.564,38$ & & $1.564,38$ & & $1.564,38$ & & $1.564,38$ & & $1.564,38$ & & $1.564,38$ \\
\hline Mão de obra administrativa & & - & & - & & - & & - & & - & & - \\
\hline Mão de obra para serviços gerais & 2 & $1.564,38$ & 2 & $1.564,38$ & 2 & $1.564,38$ & 2 & $1.564,38$ & 2 & $1.564,38$ & 2 & $1.564,38$ \\
\hline Custos $A+B+C+D$ & & $34.474,11$ & & $34.474,11$ & & $34.474,11$ & & $34.474,11$ & & $34.474,11$ & & $34.474,11$ \\
\hline
\end{tabular}


continua

\begin{tabular}{|c|c|c|c|c|c|c|c|c|}
\hline \multirow{2}{*}{ Descrição } & \multicolumn{2}{|c|}{ ANO 27 (2035) } & \multicolumn{2}{|c|}{ ANO 28 (2036) } & \multicolumn{2}{|c|}{ ANO 29 (2037) } & \multicolumn{2}{|c|}{ ANO 30 (2038) } \\
\hline & Quant. & $\mathrm{R} \$$ & Quant. & $\mathrm{R} \$$ & Quant. & $\mathrm{R} \$$ & Quant. & $\mathrm{R} \$$ \\
\hline A - Protocolo profilático sanitário & & 646,79 & & 646,79 & & 646,79 & & 646,79 \\
\hline A1 - Oficial & & 278,43 & & 278,43 & & 278,43 & & 278,43 \\
\hline Febre aftosa & 245 & 257,35 & 245 & 257,35 & 245 & 257,35 & 245 & 257,35 \\
\hline Brucelose & 50 & 21,08 & 50 & 20,08 & 50 & 20,08 & 50 & 20,08 \\
\hline A2 - Específico & & 368,36 & & 368,36 & & 368,36 & & 368,36 \\
\hline Raiva & 137 & 49,33 & 137 & 49,33 & 137 & 49,33 & 137 & 49,33 \\
\hline Clostridiose & 306 & 159,07 & 306 & 159,07 & 306 & 159,07 & 306 & 159,07 \\
\hline Everminação & 306 & 122,36 & 306 & 122,36 & 306 & 122,36 & 306 & 122,36 \\
\hline Everminação dos nascidos & 100 & 27,11 & 100 & 27,11 & 100 & 27,11 & 100 & 27,11 \\
\hline Tratamento contra onfalite & 1 & 10,50 & 1 & 10,50 & 1 & 10,50 & 1 & 10,50 \\
\hline B - Alimentação e suplementação & & $27.781,43$ & & $27.781,43$ & & $27.781,43$ & & $27.781,43$ \\
\hline B1 - Suplementação mineral & & $3.290,88$ & & $3.290,88$ & & $3.290,88$ & & $3.290,88$ \\
\hline Suplementação pronta para uso & 132 & $3.290,88$ & 132 & $3.290,88$ & 132 & $3.290,88$ & 132 & $3.290,88$ \\
\hline B2 - Alimentação & & $24.490,55$ & & $24.490,55$ & & $24.490,55$ & & $24.490,55$ \\
\hline Uréia + cana de açúcar in natura & 2.316 & $2.316,10$ & 2.316 & $2.316,10$ & 2.316 & $2.316,10$ & 2.316 & $2.316,10$ \\
\hline Concentrado - Milho (seco) & 9 & $2.708,16$ & 9 & $2.708,16$ & 9 & $2.708,16$ & 9 & $2.708,16$ \\
\hline Sulfato de amônio & 257 & 154,41 & 257 & 154,41 & 257 & 154,41 & 257 & 154,41 \\
\hline Dieta confinamento & 49 & $19.311,88$ & 49 & $19.311,88$ & 49 & $19.311,88$ & 49 & $19.311,88$ \\
\hline C - Reprodução & & $4.481,50$ & & $4.481,50$ & & $4.481,50$ & & $4.481,50$ \\
\hline C1 - Medicamentos & & $1.719,12$ & & $1.719,12$ & & $1.719,12$ & & $1.719,12$ \\
\hline Protocolo (IATF) & 96 & $1.719,12$ & 96 & $1.719,12$ & 96 & $1.719,12$ & 96 & $1.719,12$ \\
\hline C2 - Sêmem & & $1.862,38$ & & $1.862,38$ & & $1.862,38$ & & $1.862,38$ \\
\hline Sêmem & 96 & $1.862,38$ & 96 & $1.862,38$ & 96 & $1.862,38$ & 96 & $1.862,38$ \\
\hline C3 - Mão de obra específica & & 900,00 & & 900,00 & & 900,00 & & 900,00 \\
\hline Exame brucelose & - & - & - & - & - & - & - & - \\
\hline
\end{tabular}


conclusão

\begin{tabular}{|c|c|c|c|c|c|c|c|c|}
\hline Inseminação & 2 & 900,00 & 2 & 900,00 & 2 & 900,00 & 2 & 900,00 \\
\hline D - Custos Administrativos & & $1.564,38$ & & $1.564,38$ & & $1.564,38$ & & $1.564,38$ \\
\hline Mão de obra administrativa & & - & & - & & - & & - \\
\hline Mão de obra para serviços gerais & 2 & $1.564,38$ & 2 & $1.564,38$ & 2 & $1.564,38$ & 2 & $1.564,38$ \\
\hline Custos $A+B+C+D$ & & $34.474,11$ & & $34.474,11$ & & $34.474,11$ & & $34.474,11$ \\
\hline
\end{tabular}




\section{ANEXOS}

ANEXO A - Manual de Crédito Rural - PRODUSA

TÍTULO: CRÉDITO RURAL

CAPÍTULO: Programas com Recursos do BNDES - 13

SEÇÃO: Programa de Estímulo à Produção Agropecuária Sustentável (Produsa) - 8

1 - O Programa de Estímulo à Produção Agropecuária Sustentável (Produsa), com recursos do Banco Nacional de Desenvolvimento Econômico e Social (BNDES), está subordinado às normas gerais do crédito rural e às seguintes condições especiais:

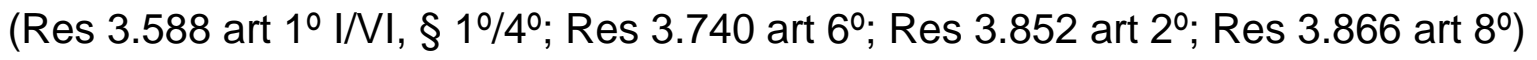

a) objetivos: (Res 3.588 art $1^{\circ} \mathrm{I} \mathrm{a} / \mathrm{g}$ )

I - disseminar o conceito de agronegócio responsável e sustentável, agregando características de eficiência, de boas práticas de produção, responsabilidade social e de preservação ambiental; (Res 3.588 art $1^{\circ}$ I a)

II - estimular ações de sustentabilidade ambiental no âmbito do agronegócio; (Res 3.588 art $\left.1^{\circ} \mid \mathrm{b}\right)$

III - estimular a recuperação de áreas produtivas degradadas, inclusive com pastagens, para o aumento da produtividade agropecuária em bases sustentáveis; (Res 3.740 art 6०)

IV - apoiar ações de regularização das propriedades rurais frente à legislação ambiental (reserva legal, áreas de preservação permanente, tratamento de dejetos e resíduos, entre outros); (Res 3.588 art $1^{\circ}$ । d)

V - diminuir a pressão por desmatamento em novas áreas, visando à ampliação da atividade agropecuária em áreas degradadas e que estejam sob processo de recuperação; (Res 3.588 art $1^{\circ} \mathrm{I}$ e)

$\mathrm{VI}$ - assegurar condições para o uso racional e sustentável das áreas agrícolas e de pastagens, reduzindo problemas ambientais; e (Res 3.588 art $1^{\circ}$ I f)

VII - intensificar o apoio à implementação de sistemas produtivos sustentáveis, como o sistema orgânico de produção agropecuária; (Res 3.588 art $1^{\circ} \mathrm{Ig}$ )

b) público alvo e abrangência: produtores rurais e suas cooperativas, inclusive para repasse a cooperados; (Res 3.595 art $\left.4^{\circ}\right)$ 
c) itens financiáveis: investimentos fixos ou semifixos relacionados com: (Res 3.588 art $1^{\circ}$ III a/d; Res 3.852 art $2^{\circ}$; Res 3.866 art $8^{\circ}$ )

I - implantação de sistemas orgânicos de produção agropecuária, inclusive serviços e insumos inerentes ao período de conversão e à fase relativa à certificação, como inscrição, inspeção e manutenção, dentre outros itens; (Res 3.588 art $1^{\circ}$ III a) II - implantação e ampliação de sistemas de integração de agricultura com pecuária ou de Integração Lavoura-Pecuaria-Silvicultura (ILPS), compreendendo: adequação do solo para o plantio, envolvendo o preparo do solo, a aquisição, transporte, aplicação e incorporação de corretivos agrícolas (calcário e outros), a marcação e construção de terraços, a realocação de estradas e o plantio de cultura de cobertura do solo; aquisição de sementes e mudas para formação de pastagens; implantação de pastagens e florestas; construção e modernização de benfeitorias e instalações destinadas à produção no sistema de integração; aquisição de máquinas e equipamentos para a agricultura e/ou pecuária, associados ao projeto de integração objeto do financiamento, não financiáveis pelo Programa de Modernização da Frota de Tratores Agrícolas e Implementos Associados e Colheitadeiras (Moderfrota); aquisição de bovinos, ovinos e caprinos, para reprodução, recria e terminação; aquisição de sêmen de bovinos, ovinos e caprinos; e assistência técnica; (Res 3.588 art $1^{\circ}$ III b 1/8)

III - correção de solos e uso de várzeas já incorporadas ao processo produtivo e projetos de adequação ambiental de propriedades rurais à legislação vigente; pagamento de serviços de agricultura de precisão (desde o planejamento inicial da amostragem do solo à geração dos mapas de aplicação de fertilizantes e corretivos); aquisição, transporte, aplicação e incorporação de corretivos (calcário, gesso agrícola e adubos para correção); gastos realizados com adubação verde; implantação de práticas conservacionistas do solo; investimentos definidos em projeto técnico específico como necessários à sistematização de várzeas já incorporadas ao processo produtivo; recuperação de pastagens degradadas (operações de destoca, implantação e recuperação de cercas nas áreas que estão sendo recuperadas, aquisição de energizadores de cerca, aquisição e plantio de sementes e de mudas pastagens e aquisição, construção ou reformas de pequenos bebedouros e de saleiro ou cochos de sal); implantação de florestas de dendezeiro em áreas produtivas degradas; e adequação ambiental de propriedades rurais, notadamente a recomposição das áreas de Reserva Legal e de Preservação 
Permanente, inclusive sistemas produtivos implementados sob o regime de manejo florestal sustentável nas Áreas de Reserva Legal; (Res 3.852 art 2º)

IV - custeio associado ao investimento, limitado a 30\% (trinta por cento) do valor financiado, observado que esse limite pode chegar a $40 \%$ quando o investimento se destinar à aquisição de bovinos, ovinos e caprinos, para reprodução, recria e terminação, bem como à aquisição de sêmen de bovinos, ovinos e caprinos. (Res 3.866 art $8^{\circ}$ )

d) fonte e condições de financiamento: (Res 3.588 art $1^{\circ} \mathrm{IV}$ a/d; Res 3.740 art 60; Res 3.852 art $2^{\circ} ;$ Res 3.866 art $8^{\circ}$ )

I - fonte e volume de recursos: Sistema BNDES, no montante de até $\mathrm{R} \$ 1.000 .000 .000,00$ (um bilhão de reais), para aplicação no período de 1/7/2010 a 30/6/2011; (Res 3.866 art $\left.8^{\circ}\right)$

II - limite de financiamento por beneficiário: até $\mathrm{R} \$ 400.000,00$ (quatrocentos mil reais), quando se tratar de projetos produtivos destinados à recuperação de áreas degradadas, e até $\mathrm{R} \$ 300.000,00$ (trezentos mil reais), nos demais casos; (Res 3.588 art $1^{\circ}$ IV b 1,2)

III - encargos financeiros: taxa efetiva de juros de 6,75\% a.a. (seis inteiros e setenta e cinco centésimos por cento ao ano) ou de 5,75\% a.a. (cinco inteiros e setenta e cinco centésimos por cento ao ano) quando se tratar de projeto destinado à recuperação de áreas produtivas degradadas, inclusive com pastagens e florestas de dendezeiro; (Res 3.852 art $2^{\circ}$ )

IV - equalização da taxa: a cargo do Tesouro Nacional, na forma da Lei $n^{\circ} 8.427$, de 1992, alterada pela Lei no 9.848, de 1999; (Res 3.588 art $1^{\circ} \mathrm{IV}$ d)

$\mathrm{V}$ - forma e prazo de reembolso: em parcelas semestrais ou anuais, conforme o fluxo de receitas do empreendimento: até 8 (oito) anos, com até 3 (três) anos de carência; até 12 (doze) anos, com até 3 (três) anos de carência, quando se tratar de sistemas produtivos de integração agricultura, pecuária e silvicultura, ressalvando-se que esse prazo só será admitido quando a componente silvicultura estiver presente; até 12 (doze) anos, com carência de até 6 (seis) anos, quando se tratar de projetos para implantação e manutenção de florestas de dendezeiro; e até 5 (cinco) anos, com até 2 (dois) anos de carência, quando o crédito for destinado, exclusivamente, para correção de solos; (Res 3.852 art $2^{\circ}$ )

e) risco da operação: da instituição financeira; (Res 3.588 art $1^{\circ} \mathrm{V}$ )

f) garantias: as admitidas no crédito rural. (Res 3.588 art $1^{\circ} \mathrm{VI}$ ) 
2 - Com relação ao disposto no item anterior, deve ser observado: (Res 3.588 art $1^{\circ}$ $\S 1 \% 4^{\circ}$ )

a) quando se tratar de projeto produtivo que envolva recuperação de áreas degradadas deve ser exigido, como pré-requisito, Projeto Técnico Agronômico específico, assinado por profissional habilitado, contemplando obrigatoriamente:

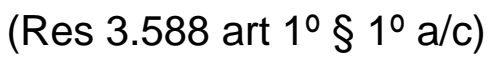

I - identificação da área total do imóvel, juntamente com o croqui da área a ser

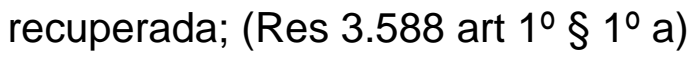

II - apresentação de comprovantes de análise do solo e da respectiva recomendação agronômica; e (Res 3.588 art $1^{\circ} \S 1^{\circ} \mathrm{b}$ )

III - laudo conclusivo que ateste tratar-se de área degradada, podendo conter relatório fotográfico para a visualização de processos erosivos e histórico da área;

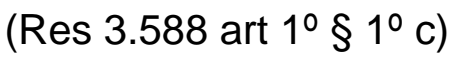

b) os limites de financiamento definidos no inciso II da alínea "d" podem ser elevados em 15\% (quinze por cento) para o beneficiário que comprovar a existência de Área de Reserva Legal averbada e de Áreas de Preservação Permanente, na propriedade onde o empreendimento será instalado, como previsto no Código Florestal Brasileiro, ou apresentar plano de recuperação com anuência da Secretaria Estadual do Meio Ambiente, do Instituto Brasileiro do Meio Ambiente e dos Recursos Naturais Renováveis (Ibama) ou do Ministério Público Estadual; (Res 3.588 art $1^{\circ} \S 2^{\circ}$ )

c) os limites de crédito do programa de que trata esta seção não são excludentes entre si e independem de outros créditos contraídos ao amparo de recursos controlados do crédito rural; ( Res 3.588 art $\left.1^{\circ} \S 3^{\circ}\right)$

d) é admitida a concessão de mais de um crédito por tomador por ano safra, quando a atividade assistida requerer e ficar comprovada a capacidade de pagamento do beneficiário e o somatório dos valores não exceder o limite de crédito estabelecido para o programa. (Res 3.588 art $\left.1^{\circ} \S 4^{\circ}\right)$

3 - Fica autorizada, no âmbito do Produsa, a concessão de crédito emergencial para financiamento de orizicultores do Rio Grande do Sul, cujos municípios tenham decretado, em decorrência de enchentes, chuvas excessivas, trombas-d'água e enxurradas, situação de emergência ou estado de calamidade pública entre os dias 1/11/2009 e 31/3/2010, reconhecido pelo Governo Estadual, para recuperação da 
capacidade produtiva de áreas danificadas e para a implantação da safra 2010/2011, nessas mesmas áreas, observadas as normas gerais estabelecidas para a concessão de crédito rural e seguintes condições adicionais: (Res 3.858 art 10; Res $3.873 \operatorname{art~}^{\circ}$ )

a) beneficiários: orizicultores cuja área de produção esteja localizada nos municípios de que trata o caput e que tiveram toda ou parte de sua unidade produtiva danificada pelos eventos, comprovada por meio de laudo técnico elaborado por profissional habilitado, reconhecido pela instituição financeira; (Res $3.873 \mathrm{art}^{\circ}$ )

b) itens financiáveis: despesas necessárias à recuperação de benfeitorias e infraestrutura danificadas pelos eventos de que trata este item, bem como despesas referentes aos custos de formação da área danificada na safra 2009/2010; (Res 3.873 art $\left.1^{\circ}\right)$

c) limite por beneficiário: $\mathrm{R} \$ 600.000,00$ (seiscentos mil reais), não podendo ultrapassar a $\mathrm{R} \$ 2.500,00$ (dois mil e quinhentos reais) por hectare de arroz, limitado ao financiamento da área que efetivamente demande recuperação, independente de outros limites estabelecidos para esse programa; (Res 3.873 art 10)

d) encargos financeiros: taxa efetiva de juros de 5,75\% a.a. (cinco inteiros e setenta e cinco centésimos por cento ao ano); (Res 3.858 art $\left.1^{\circ}\right)$

e) forma e prazo de reembolso: em parcelas semestrais ou anuais, conforme o fluxo de receitas do empreendimento, observado o prazo de até oito anos, com até dois anos de carência; (Res 3.858 art $1^{\circ}$ )

f) prazo para contratação: até 30/9/2010; (Res 3.858 art 10)

g) risco da operação: da instituição financeira; (Res 3.858 art 1)

h) garantias: as admitidas no crédito rural; (Res 3.858 art 10)

i) fonte e limites de recursos: Sistema BNDES, no montante de $R \$ 204.000 .000,00$ (duzentos e quatro milhões de reais). (Res 3.858 art $1^{\circ}$ ) 
ANEXO B - Projeto de Layout e Implantação

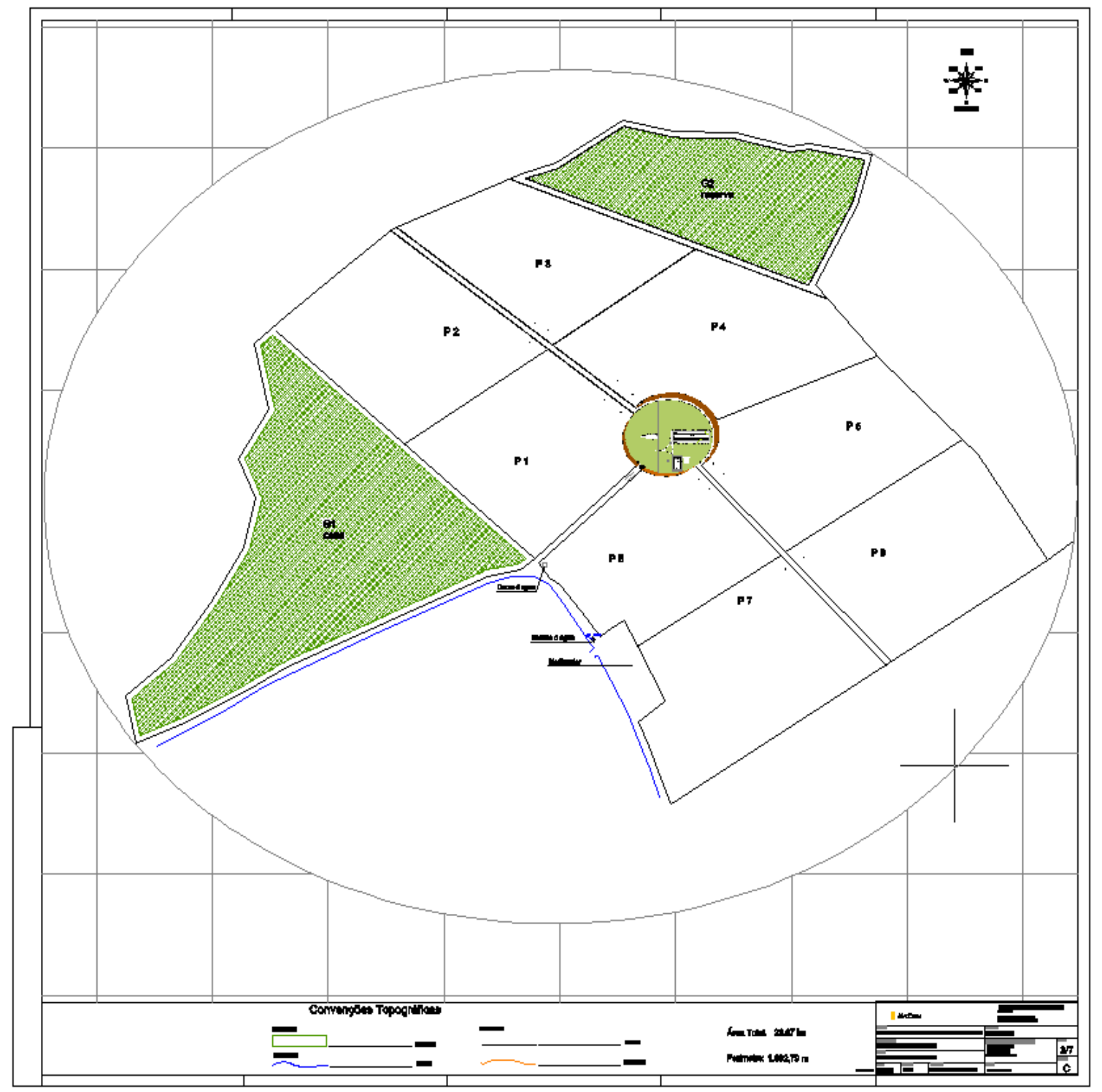


ANEXO C - Projeto das Instalações

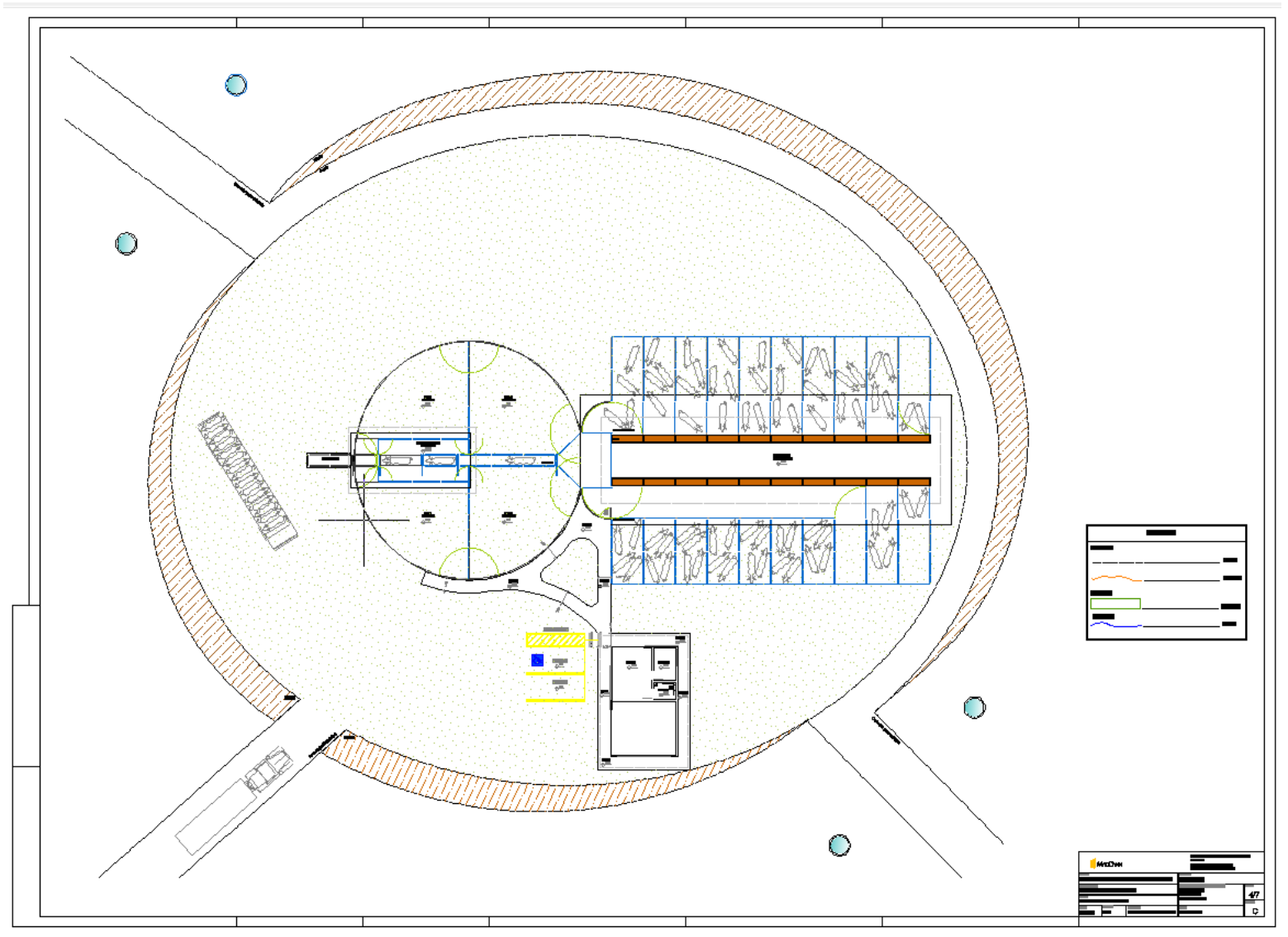

